Portland State University

PDXScholar

Spring 5-22-2014

\title{
Supply Chain Risk Management in India: An Empirical Study of Sourcing and Operations Disruptions, their Frequency, Severity, Mitigation Methods, and Expectations
}

Andreas Udbye

Portland State University

Follow this and additional works at: https://pdxscholar.library.pdx.edu/open_access_etds

Part of the Operations and Supply Chain Management Commons Let us know how access to this document benefits you.

\section{Recommended Citation}

Udbye, Andreas, "Supply Chain Risk Management in India: An Empirical Study of Sourcing and Operations Disruptions, their Frequency, Severity, Mitigation Methods, and Expectations" (2014). Dissertations and Theses. Paper 1813.

https://doi.org/10.15760/etd.1812

This Dissertation is brought to you for free and open access. It has been accepted for inclusion in Dissertations and Theses by an authorized administrator of PDXScholar. Please contact us if we can make this document more accessible: pdxscholar@pdx.edu. 
Supply Chain Risk Management in India: An Empirical Study of Sourcing and

Operations Disruptions, their Frequency, Severity, Mitigation Methods, and Expectations

by

Andreas Udbye

A dissertation submitted in partial fulfillment of the requirements for the degree of

Doctor of Philosophy

in

Systems Science: Business Administration

Dissertation Committee:

Lee Buddress, Chair

Timothy R. Anderson

David M. Raffo

Wayne Wakeland

Portland State University

2014 
(C) 2014 Andreas Udbye 


\begin{abstract}
With an annual growth of almost $20 \%$ since the year 2000, Indian merchandise exports exceeded 300 billion U.S. dollars in 2012. The country is becoming a major supplier to the world. However, companies sourcing products and operating in India are experiencing a variety of supply chain disruptions that impede their operations and finances. The purpose of this dissertation is to investigate the frequency, impact and severity of supply chain risks experienced by companies in India, as well as assess the usefulness of mitigation methods and enquire about future expected disruptions. It is hoped that the results will prepare managers to better prioritize their supply chain risk management efforts and investments. The scope of this study is upstream (sourcing and operations) disruptions that affected Indian supply chains over the past three years, including the areas of logistics and transportation. The methodology is a quantitative, empirical study, using a survey instrument in the form of a questionnaire distributed electronically to thousands of members of four prominent trade associations in India. The platform for the questionnaire is a modification of a traditional risk analysis progression: mapping, identifying, assessing, mitigating and improving, also dubbed "MIAMI".

The main findings are that there are major and significant differences in severity (frequency and impact) between the thirteen risk categories presented. There are also significant group differences among the respondents. Traditional mitigation methods differ with respect to usefulness, and expected risks are somewhat different than past
\end{abstract}


risks. Conclusions reached are that chronic risks such as inadequate transportation, logistics and utilities infrastructure, supplier and labor problems, and bureaucracy/red tape are more severe than highly publicized and visible risks such as natural disasters, terrorism and crime. Traditional mitigation methods are useful for many of the disruptions, but ineffective for non-physical risks. There is a certain optimism with respect to future infrastructure related disruptions.

Limitations of the study include a relatively low response rate, the classic difficulty in risk analysis of comparing and scaling the impact of disruptions, and that it is not fine grained enough to fully describe any specific industry sectors. This study contributes to the field of supply chain risk management by adding crucial empirical information from a heretofore unexplored market. 


\section{DEDICATION}

The dissertation is dedicated to my faithful wife, Kari, who not only financed a great deal of my self-actualization project, but also suffered through more than five

years of stress, distractions and excuses. Obtaining a doctorate at middle age is hard on the family.

I cannot thank her enough. 


\section{Table of Contents}

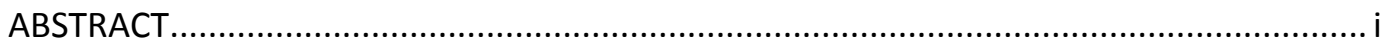

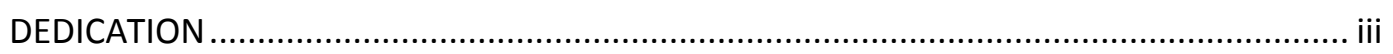

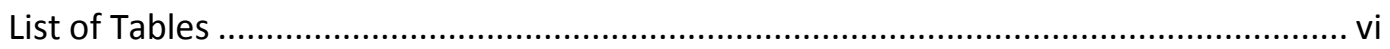

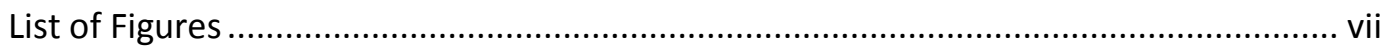

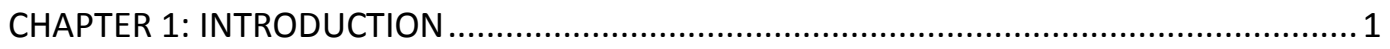

CHAPTER 2: SOME BACKGROUND ON INDIA ........................................................ 5

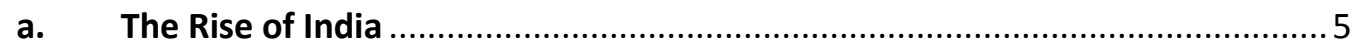

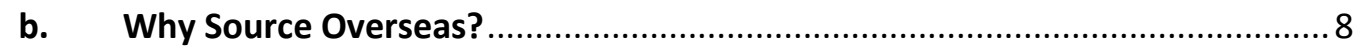

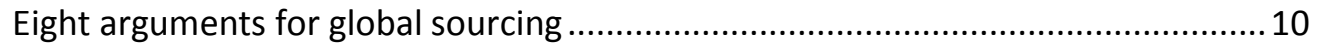

Further arguments for sourcing in India .............................................................. 14

CHAPTER 3: LITERATURE REVIEW AND CURRENT KNOWLEDGE .................................. 16

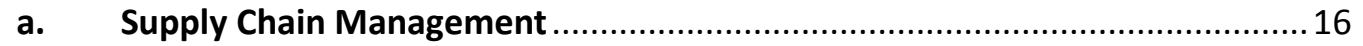

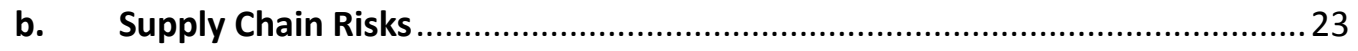

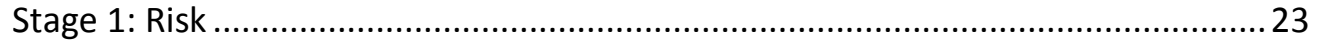

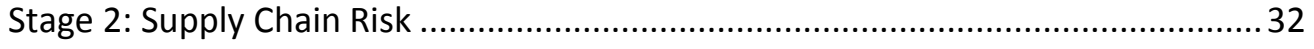

Stage 3: Supply Chain Risk Management............................................................... 42

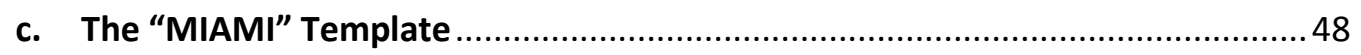

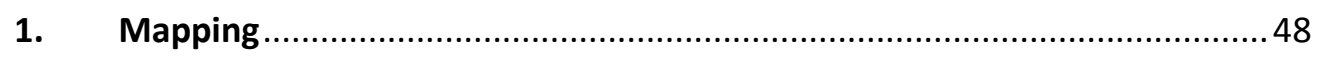

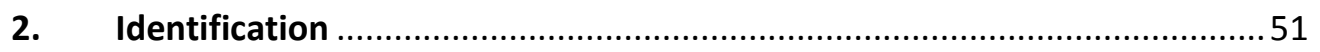

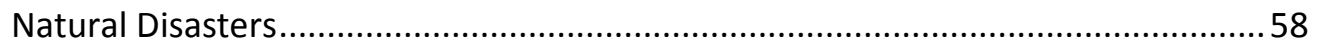

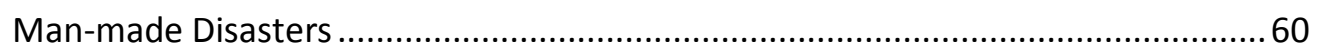

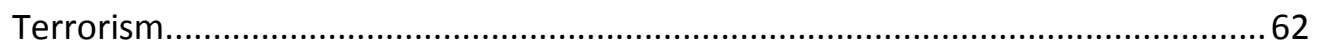

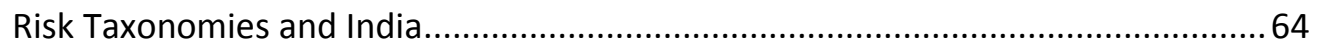

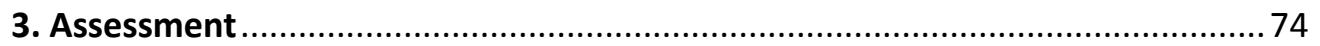

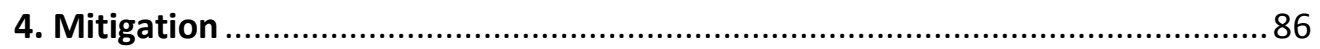

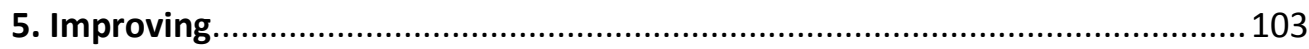

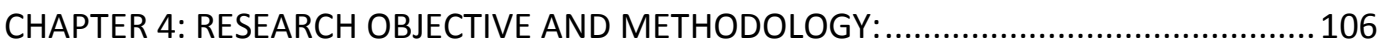

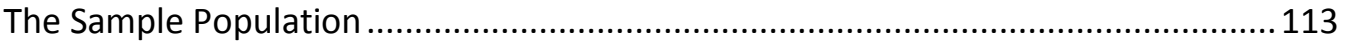

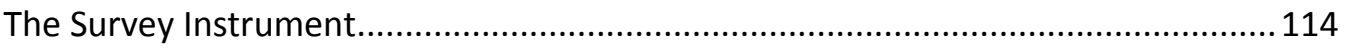

CHAPTER 5: FINDINGS AND RESULTS OF THE RESEARCH .......................................120

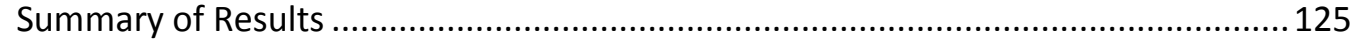

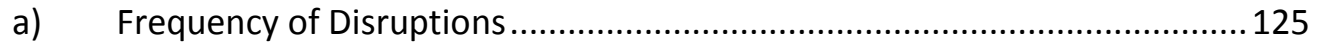

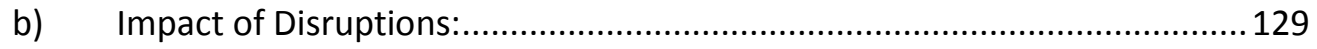


c) Severity of disruptions ("risk assessment score"):.....................................132

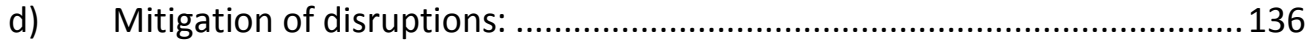

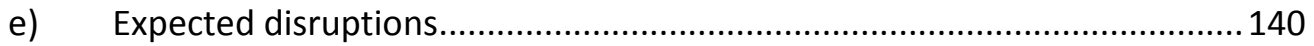

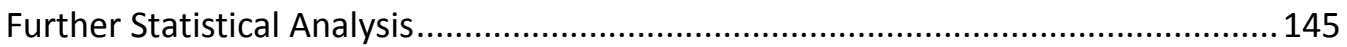

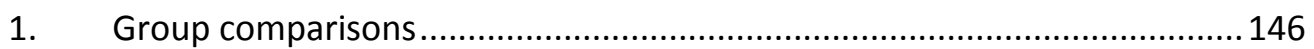

2. Combinations of Predictor Variables? ..................................................149

3. Prediction and Multiple Regression........................................................ 150

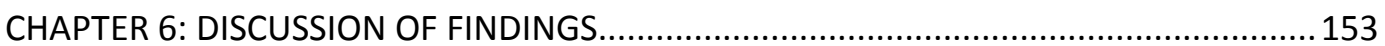

Significance, Contribution and Limitations of this Work ............................................ 162

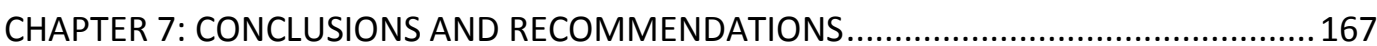

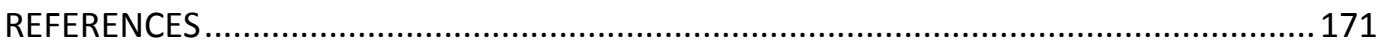

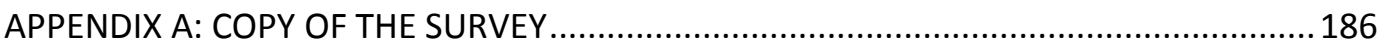

APPENDIX B: SUPPORTING INFORMATION ON NATURAL DISASTERS IN INDIA .............214

APPENDIX C: SUPPORTING INFORMATION ON MANMADE DISASTERS IN INDIA ..........220

APPENDIX D: SUMMARY OF RESPONSES TO THE PROFILE QUESTIONS ........................225 


\section{List of Tables}

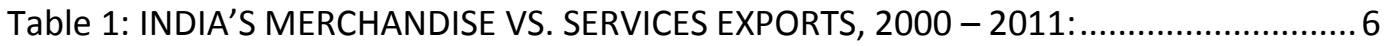

Table 2: DEFINITIONS OF SUPPLY CHAIN, IN CHRONOLOGICAL ORDER .........................17

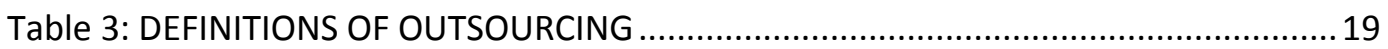

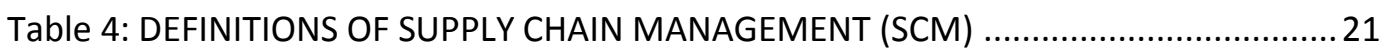

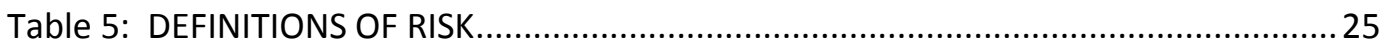

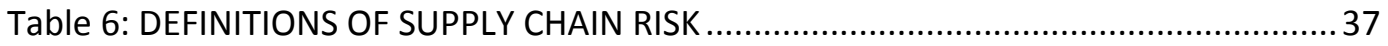

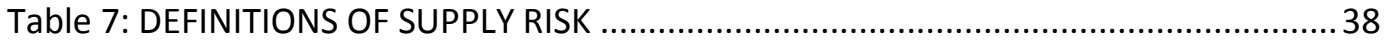

Table 8: DEFINITIONS OF SUPPLY CHAIN RISK MANAGEMENT (SCRM) …..................... 44

Table 9: VARIOUS BUSINESS ENVIRONMENT INDICES ..................................................5

Table 10: THE ECONOMIST'S EXPECTED GDP PER CAPITA IN 2013, SELECT ASIAN

COUNTRIES .56

Table 11: INDIAN DISASTERS VIS-A-VIS CHINA AND THE U.S. (\% share of world totals) 60 Table 12: CLASSIFICATION OF RISKS AND EXAMPLES RELEVANT TO INDIA ..................... 71

Table 13: WIDELY PUBLICIZED DISASTERS 2010 - 2012 AND THEIR IMPACT ....................83

Table 14: HOW RECENT SURVEYS RANKED SOURCES OF DISRUPTION ........................101

Table 15: ARTICLE SEARCH RESULTS FOR “INDIA(N) SUPPLY CHAIN RISK": ....................107

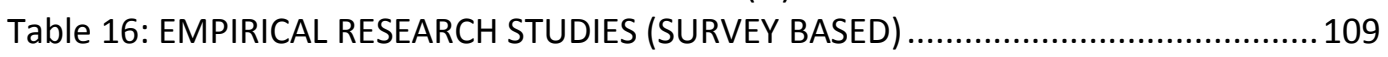

Table 17: DISRUPTION AND MITIGATION MATRIX ....................................................117

TABLE 18: OUTPUT FROM SPSS SHOWING NO DIFFERENCES BETWEEN EARLY AND LATE RESPONSES

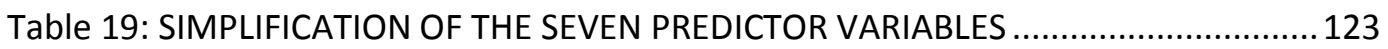

TABLE 20: WRITE-INS WITH RESPECT TO FREQUENCIES OF DISRUPTIONS. ....................126

Table 21: FREQUENCY OF DISRUPTIONS (in the same order as in the questionnaire): . 127

TABLE 22: RANKING, SUMMARY AND AVERAGE OF OCCURRENCES:.............................128

Table 23: IMPACT OF DISRUPTIONS (in the same order as in the questionnaire): .........130

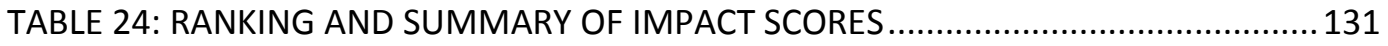

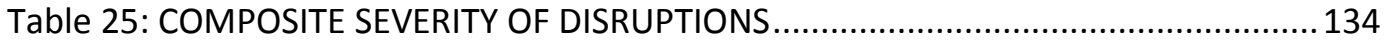

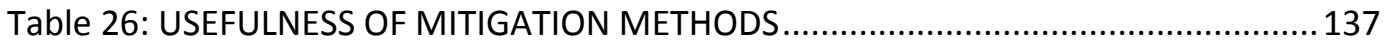

TABLE 27: SUMMARY OF MITIGATION USEFULNESS FOR TOP SIX RISKS ........................138

Table 28: MITIGATION METHODS DEEMED USEFUL OR VERY USEFUL FOR THE TOP SIX

RANKED DISRUPTIONS.

Table 29: EXPECTED FREQUENCY OF DISRUPTIONS THE NEXT THREE YEARS .................141

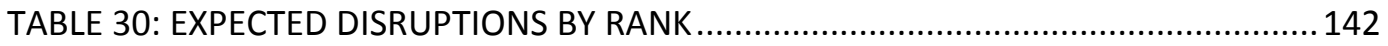

Table 31: RISKS NOT EXPECTED THE NEXT THREE YEARS: ............................................. 144

Table 32: CHECKING FOR SIGNIFICANT GROUP DIFFERENCES USING SIGNIFICANCE

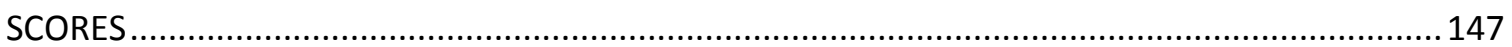

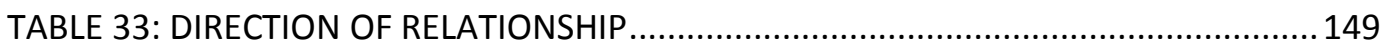

TABLE 34: SIGNIFICANT CROSS-CORRELATIONS BETWEEN PREDICTOR VARIABLES ......150

TABLE 35: COMPLETE PREDICTOR VARIABLE CROSS-CORRELATION TABLE .................... 151

TABLE 36: MODEL SUMMARIES OF MULTIPLE REGRESSION ....................................... 152

Table 37: COMPARISON OF RANKING OF FREQUENCY, IMPACT, SEVERITY, MITIGATION AND EXPECTED RISKS. 
List of Figures

Figure 1: THE FOCUS OF THIS DISSERTATION ............................................................ 7

Figure 2: THE PROBABILITY (LIKELIHOOD) VS. THE IMPACT (CONSEQUENCES) OF DISRUPTIONS

FIGURE 3: FREQUENCY VERSUS IMPACT CHART FOR EACH DISRUPTION ......................133

Figure 4: HISTOGRAM OF SEVERITY SCORES . 


\section{CHAPTER 1: INTRODUCTION}

Companies sourcing products and services in far-away places are best served by having in place plans and programs for handling the many risks involved. Bad things will inevitably happen to long and complex supply chains that are under pressure to deliver goods expediently and cheaply. Supply chain risk management is a growing and increasingly formalized practice for treating the various supply chain risks. Its focus is on preventing costly disturbances from happening or minimizing the impact of the disturbances ${ }^{1}$ that inevitably happen in global supply chains. This dissertation builds on a solid foundation of academic and practitioner research and literature and uses a certain methodology for assessing supply chain risks in the emerging economy of India. This empirical study applies the framework of mapping, identification, assessing, mitigating and improving ("MIAMI") when enquiring supply chain executives about risks they have experienced.

Sodhi et al. concluded a 2012 paper in Production and Operations Management with their finding that there are three gaps pertinent to future research in supply chain risk management: 1) No clear consensus on the definition of SCRM (Supply Chain Risk Management); 2) Lack of commensurate research on response to supply chain risk incidents; and 3) a shortage of empirical research in the area of SCRM (Manmohan S.

\footnotetext{
${ }^{1}$ According to Webster's Dictionary, both disturb and disrupt mean to "throw into disorder". This dissertation uses the term disruption most of the time, but occasionally the synonym disturbance is applied (Merriam-Webster, 1976). Disruption can be further defined as "an event that results in a displacement or discontinuity; the act of causing disorder" (J. C. Coyle, Novack, Gibson, \& Bardi, 2011)
} 
Sodhi, Son, \& Tang, 2012). This dissertation attempts to add to the body of knowledge by modifying a methodological framework and contributing up-to-date empirical information to aid the profession in controlling and reducing supply chain risks.

Supply chain risk management has become a high priority issues for companies operating in global markets. The ability to meet customer demand and preserve the financial bottom line hinge on effective preparation and mitigation efforts. Sourcing and operating in less developed economies present supply chain managers with a new set of potential risks and uncertainties.

India's economy is growing rapidly. Its exports sector has been experiencing an annual growth of almost $20 \%$ for the past few years, as more companies perform sourcing and production there. It is expected that India will become a more realistic and attractive alternative for many categories of goods and services. India is still inexpensive, with an abundance of labor and a very promising demographic profile. However, the country represents a cocktail of serious supply chain risks for firms attempting to source or produce there. This dissertation will survey Indian supply chain managers on what specific risks they encounter, what impact these risks had on their companies, what mitigation steps may have worked, and what specific risks they expect to experience in the future. We also check for group differences. For example, do foreign owned firms have different risk experiences than Indian firms?

The usefulness of this research cannot be overestimated. So far, articles, news reports and commentaries about doing business in India have been full of mostly anecdotal stories of the risks and disturbances experienced there. Literature on Indian 
supply chains describe poor infrastructure, bureaucratic delays, red tape and the prevalence of corruption. A comprehensive review of the literature reveals no academic studies that enquire on-the-ground practitioners about the identification, assessment and mitigation of supply chain risks in India. The results of this research will be valuable for companies contemplating or currently sourcing and producing there. It is hoped that the results will reveal the issues of real concern to supply chain managers in India, and can help practitioners focus in on risk factors that deserve immediate attention.

It appears that India is not necessarily riskier than other countries in Asia when it comes to supply chain exposures. Overall risk consists of a mosaic of miscellaneous operational and environmental disruptions. India has a different set of risks than China, for example, or even Pakistan and Bangladesh next door. Each specific supply chain is also different, meaning that the interplay between this and the country's environmental factors determine the relevant risk topography and circumstances for a company. The risk exposure, experience and impact will depend on a given company's industry and product categories.

Although supply chains span from raw materials to the ultimate consumers, this dissertation limits its focus to the upstream portion, specifically the sourcing and production in India. However, any such delineation has fuzzy borders. Many of the downstream risks are the same as the upstream risks. This dissertation is concerned with the supply chain risks encountered within India. Whether these are within the upstream or downstream portion of the supply chain is of less concern. 
The dissertation is organized as follows: A comprehensive literature review outlines the attractiveness of sourcing in India, defines global supply chains and supply chain risk, and discusses what modern supply chain risk management encompasses. Thereafter, the attention will be on a thorough review and discussion of the five MIAMI steps: mapping the supply chain, identifying relevant risks, assessing the probability and impact of these risks, mitigating the relevant risks through prevention and minimization strategies, and improving the risk management process through a system of control, monitoring and learning. The dissertation culminates with the empirical study. The research methodology and survey process are explained in Chapter 4, and the results are revealed and discussed in Chapters 5 and 6. Chapter 7 is a concluding chapter that recaps the overall findings, makes some comments on possible causalities, suggests that some Indian risks are not remedied with traditional mitigation methods, and recommends general paths for further and more pin-pointed research into Indian supply chain risks. 


\section{CHAPTER 2: SOME BACKGROUND ON INDIA}

\section{a. The Rise of India}

India is no longer an exotic destination for sourcing and procurement.

Globalization has moved India closer in many ways, and it is much easier now for foreign companies to do business there. Foreign and Indian owned firms are producing more goods and services within India than at any time in history. The country's exports and domestic consumption are at record highs. India's gross domestic product (GDP) per capita doubled over the ten years from 2002 to 2012. According to the World Bank ${ }^{2}$, the annual GDP growth averaged 7.1\% over the 12-year period from 2000 to 2011, with a high of $9.8 \%$ in 2007 and lows of $3.9 \%$ in 2002 and 2008. After a slowdown in 2012-13, The Economist Magazine projects the 2014 growth will be 7.3\% (Economist, 2013b). In terms of GDP, India is now the world's tenth largest economy, although some sources already put it third in $\mathrm{PPP}^{3}$-adjusted terms, after the U.S. and China (McKinsey, 2013).

The country's exports have experienced an even more impressive growth. From 2000 to 2011 the merchandise exports grew from US\$ 42 billion to US\$ 301 billion ${ }^{4}$, equal to an average compound growth rate of $19.6 \%$. In fact, since 2007 this growth rate has accelerated to an average of $19.8 \%$. In comparison, China's average exports growth rate from 2000 to 2011 was a bit higher at 20.3\%, but this slowed to an average of $11.7 \%$ between 2007 and 2011. In addition to merchandise exports - which include

\footnotetext{
${ }^{2}$ http://data.worldbank.org/indicator/NY.GDP.MKTP.KD.ZG

3 "Purchasing Power Parity" adjusts currency exchange rates to reflect real purchasing power

${ }^{4}$ Hereafter, all dollar amounts will be in U.S. dollars.
} 
tangible goods and commodities - India has a thriving services exports sector, adding another $50 \%$ to total exports. The total annual exports of $\$ 450$ billion are a huge contributor to the country's $\$ 2$ trillion economy. In 2011, India was the world's $19^{\text {th }}$ largest merchandise exporter and the $6^{\text {th }}$ largest services exporter 5 . Table 1 compares the growth in India's merchandise vs. services exports since the year 2000. Despite a leveling out in 2012, with these types of longer term growth rates, exports will soon exceed one quarter of India's official economic output, and the country will move up into the upper echelons of global export powerhouses.

Table 1: INDIA'S MERCHANDISE VS. SERVICES EXPORTS, 2000 - 2011:

\begin{tabular}{|l|l|l|l|}
\hline Category: $^{\mathbf{6}}$ & Year 2000: & Year 2011: & $\begin{array}{l}\text { Compound average } \\
\text { growth:: }\end{array}$ \\
\hline Merchandise exports & $\$ 42$ billion & $\$ 301$ billion & $19.6 \%$ \\
\hline Services exports & $\$ 17$ billion & $\$ 148$ billion & $21.7 \%$ \\
\hline Total & $\$ 59$ billion & $\$ 449$ billion & \\
\hline
\end{tabular}

Sourcing from India is likely to keep growing at a rapid rate over the next decades. Consumers all over the world are likely to see more "Made in India" tags, and the country can expect a boom in exports of raw materials, components, finished products and services. Long and complex supply chains, combined with corporate performance and efficiency pressures, make for some interesting risk scenarios in a country as diverse and arguably chaotic as India. Sahay et al. suggest that managing the

\footnotetext{
${ }^{5}$ http://www.wto.org/english/news e/pres12 e/pr658 e.htm

${ }^{6}$ Merchandise exports: Tangible goods exported. Services exports: Business, technical or professional services Incl. software); travel; passenger fares; transportation; royalties and license fees
} 
supply chain in such a vast country as India is most challenging for companies because of business practices, government regulations, technological capability and transportation infrastructure, among other factors (Sahay, Gupta, \& Mohan, 2006).

Global companies have many choices from where to source their products. Figure 2 illustrates a particular chosen path, where companies decide to outsource ${ }^{7}$ production to an offshore location, in this case India. In India, companies either deal with arms-length suppliers or set up their own subsidiaries, which again tend to source locally from $2^{\text {nd }}$ tier suppliers and so on.

\section{Figure 1: THE UPSTREAM FOCUS OF THIS DISSERTATION}

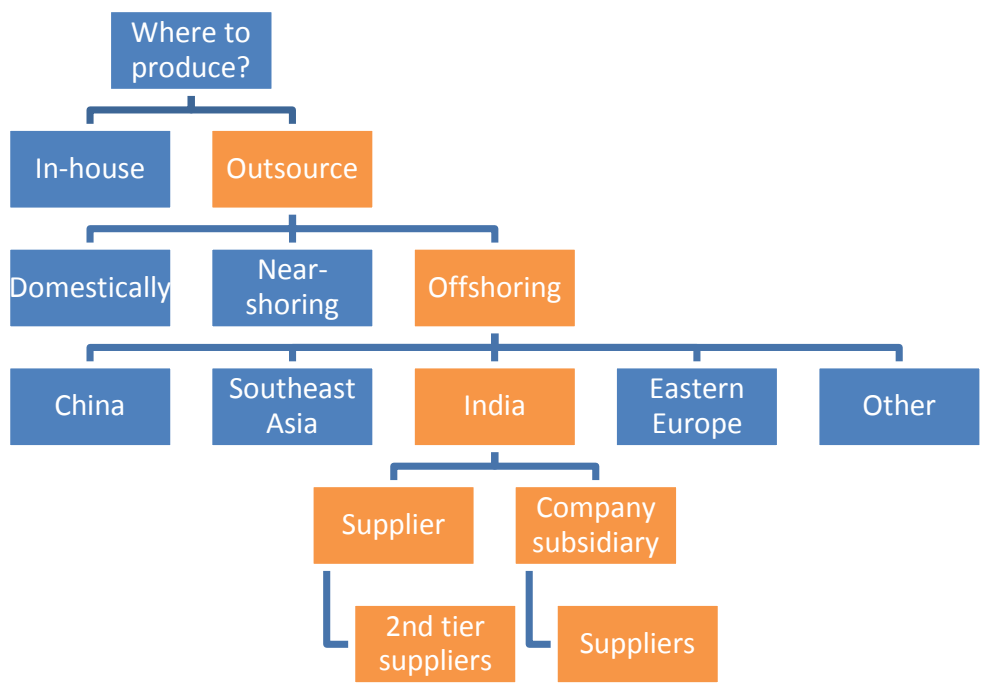

${ }^{7}$ A useful definition of sourcing: "The act through which work is contracted or delegated to an external or internal entity that could be physically located anywhere". Outsourcing is defined as a subset of this, i.e. "contracting with a third party provider" (Oshri, Kotlarsky, \& Willcocks, 2011), p.7.

We prefer the term "global sourcing" over similar terms such as "outsourcing" and "offshoring". Outsourcing is a practice that does not necessarily involve foreign trade; a company that hires a janitorial service to clean its offices is outsourcing an activity that previously may have been done in-house. Offshoring typically refers to companies moving its production facilities abroad and setting up factories there. Another acceptable synonym for global sourcing is the more maritime sounding "offshore sourcing", although it raises the question of whether Canada and Mexico are really offshore in relation to the United States. See table 3 for examples of definitions and nuances. 


\section{b. Why Source Overseas?}

Companies source abroad because it makes sense economically. Globalization in its many manifestations has broken down crucial barriers that previously prevented a smooth worldwide trade in goods and services: regulatory barriers, tariff barriers, communications barriers, transportation barriers, immigration barriers, cultural barriers, and so on. With the gradual breakdown of factors that prevented global commerce, we have seen global exports as a percentage of global output (nominal GDP) rise from 12\% in 1980 to more than 25\% in 2011 (various sources, incl. World Bank and World Trade Organization $)^{8}$. Global trade has doubled in relative importance the past thirty years. One can argue that this is due to a self-reinforcing process: the more that rich nations import from the developing nations, the more these developing nations are able to build their own economies and import back from the rich nations.

Typical drivers for global sourcing can include:

- Price and competitive pressures (Olson, 2012)

- Globalization and trade liberalization (breakdown of trade barriers)

- Easier and cheaper communications (digitalization, data transfers, travel, transportation networks, incl. containerized shipping technology)

- Qualified and cheap labor abroad

- Rise of the global consumer and purchasing power in Asia

While stating that the ultimate objective of a company's global sourcing strategy is to exploit both its own and its suppliers' competitive advantages and the comparative locational advantages of various countries in the global competition, Kotabe and Murray

\footnotetext{
${ }^{8}$ The nominal world GDP is reported to have been $\$ 70.1$ trillion in 2011 and $\$ 18.8$ trillion in 1980. World exports (obviously identical to world imports) were $\$ 17.8$ trillion in 2011 and $\$ 2.3$ trillion in 1980.
} 
also make an interesting observation that in the U.S., managements' strategic emphasis has drifted away from manufacturing to marketing and finance over the years (Kotabe \& Murray, 2004). In other words, American firms did not see a value or core competency in manufacturing, and were more likely to move this activity overseas.

The Economist Magazine, in a January 2013 Special Report on outsourcing and offshoring, outlined the broad range of variables, including the complex web of strategies, priorities and risks now faced by managers of multinational companies. (The_Economist, 2013). Globalization is serving as the "great equalizer", making the cost differences between the West and the developing world less stark and less of an economic argument for offshoring. Other arguments - often conflicting - are often heard. For example, more automated production makes it less beneficial to rely on low cost labor, while growing consumer markets in emerging economies renders it more economical to locate production plants there. A chart in The Economist's special report forecasted the "manufacturing outsourcing cost index"9 of China to be practically equal to the U.S. in 2015 , while for India the forecast for 2015 was $83 \%$ of the U.S. cost. The surprising prediction for China is confirmed by the official Chinese newspaper China Daily, which reported that Chinese wages saw double digit growth of $14.3 \%$ between 2010 and $2011^{10}$. China's rapid wage increases, combined with a U.S. stagnation in

\footnotetext{
${ }^{9}$ Although the magazine did not specify how it arrived at this index, it mentioned that high transportation costs and delays partially offset the lower labor costs. The index can be considered a measure for total landed cost.

${ }^{10}$ www.chinadaily.com.cn/business/2012-05/29/content 15416969.htm
} 
manufacturing wages since the 1990's, means the wage gap has narrowed between

China and the U.S.

\section{Eight arguments for global sourcing}

Deresky suggests five main reasons why companies find it beneficial to do global sourcing (Deresky, 2008). How these relate to India is discussed in more detail below:

1. Save money (experience cost efficiencies; lower cost of production)

2. Access to foreign markets and customers

3. Avoid trade barriers

4. Diversify production

5. Leverage global talent (access to human resources)

Three other reasons found in the international business literature include:

6. Reduce fixed costs at home and be more flexible (Cullen \& Parboteeah, 2008)

7. Improved agility by shedding unnecessary overhead (S. T. Cavusgil, G. Knight, \& J. S. Riesenberger, 2008b)

8. Gain access to suppliers' capabilities (Kotabe \& Murray, 2004)

1. Save money:

Indian factory workers are often paid less than $\$ 1,000$ per year, and even engineers with doctoral degrees may receive annual salaries of no more than $\$ 10,000$. Nevertheless, supply chain professionals are concerned with the Total Landed Costs, or the Total Cost of Outsourcing - TCO - (Mangan, Lalwani, \& Butcher, 2008), which includes:

- The basic cost of the product of service (of which the labor cost is a component)

- The cost incurred to manage the outsourcing arrangement (incl. setting up, monitoring from beginning to end of the relationship, coordination, risk management and contingency planning)

- Added transportation and inventory costs 
There are now reports that companies sourcing in China are finding that the overall cost savings are less than they hoped for and what they experienced just a few years ago (Rein, 2012; Shister, 2011). Several authors have observed a possible loss of Chinese competitiveness. Some of it is due to rising costs and a strengthening Renminbi. Steeply rising wages and higher rents take a toll on factories that rely on cheap inputs (Bradsher, 2012; Rein, 2012) ${ }^{11}$. Because of rough labor conditions and workers becoming more assertive about their rights, there also appears to be more frequent factory riots, strikes and worker unrest in China (Barboza \& Bradsher, 2012; Wan, 2012). These result in plant closings; for example Foxconn Technology's production of iPhones was interrupted in the fall of 2012 (Foxconn supplies Apple, Dell, HP and Microsoft).

\section{Gain access to foreign markets and customers}

Setting up production arrangements or facilities in foreign countries can serve at least three purposes: 1) production for sale and consumption in the host country; 2) sourcing and production for exports back to the home country; and 3) production for sale and consumption to countries with which the host country has free trade agreements. An example of the third case would be to manufacture items in India that are marketed to other Asian countries. Such sales would often benefit from regional free trade agreements.

\footnotetext{
${ }^{11}$ In his 2012 book, Rein lists several reasons why China is in the process of losing its
} competitiveness, for example, 1) more expensive production through rising labor costs, high labor turnover, expensive land and buildings, rising currency, inflation, and higher commodities prices; and 2) business risks such as inconsistent product safety and quality, corruption, weak judicial system, corner cutting, shoddy real estate construction, and poor educational system. He also claims that China is not putting more emphasis on domestic consumption and production for its home markets (Rein, 2012) 


\section{Avoid Trade Barriers}

India's high import tariffs, trade restrictions and discrimination against foreign products $^{12}$ (India is not a signatory to the World Trade Organization's Agreement on Government Procurement (Makar, 2008)) often make it more attractive to manufacture within India the products to be sold there.

\section{Diversify Production}

From a supply continuity standpoint it makes perfect sense to diversify the production of high value products over two or more facilities. Diversification (having redundancies) is one of the classic mitigation methods for reducing overall supply chain vulnerability.

\section{Leverage Global Talent}

Multinationals such as IBM and Microsoft are benefiting from a good supply of Indian professionals with engineering, science and programming backgrounds.

Internally, large corporations can also free up expensive home country labor by shifting certain tasks to cheaper labor at other locations of their sprawling, global networks.

6. Reduce fixed costs at home and be more flexible

As Kotabe and Murray have pointed out, global outsourcing usually reduces the capital investment in in-house manufacturing facilities, thus lowering the company's

12 The U.S. Dept. of Commerce writes: "Current procurement practices can result in discrimination against foreign suppliers when goods or services of comparable quality and price are available locally" (Commercial_Service, 2012). 
fixed assets, its breakeven point, and boosting its ROA (return on assets) and ROE (return on equity) given the same operating margins (Kotabe \& Murray, 2004). Company executives have a strong incentive to seek better returns, and will tend to increase outsourcing to accomplish this. Switching from high fixed capital costs to a variable cost environment will be beneficial in a market that is unpredictable, volatile and in need of production and marketing flexibilities.

\section{Improve agility by shedding unnecessary overhead}

The flexibility created by moving to a variable cost scenario improves agility and the capability to respond quickly to changes in markets, technologies and the environment (Bowser \& Balasubramaniam, 2009; Christensen, 2003). Agility implies greater organizational flexibility and faster responsiveness to evolving customer needs (Cavusgil et al., 2008b).

\section{Gain access to suppliers' capabilities}

In complex supply chains, each link will have specific core competencies that add value to the "value chain"13. For many firms it is cheaper and makes more sense to find suppliers that can contribute value to the production process, rather than building up or continuing in-house activities. Indian suppliers have competitive strengths that add value to the total product, including but not limited to inexpensive and highly qualified

\footnotetext{
${ }^{13}$ Value chain: The sequence of value-adding activities performed by the participants in the supply chain in the process of developing, producing, marketing and servicing a product (Cavusgil et al., 2008b)
} 
labor, engineering and software coding talent, highly experienced textile workers and tailors, and valuable raw materials, especially mined and agricultural products.

\section{Further arguments for sourcing in India}

If "demographics is destiny", India will have an ample supply of labor for decades to come, creating an obvious and partially untapped potential. While cost reduction is the primary driver to India (Deresky, 2008), much has been written lately about other benefits of doing business or investing there. Examples include ongoing economic reforms, trade liberalization, deregulation, infrastructure investments, and the membership in the World Trade Organization. Many multinationals appreciate the advanced English skills, a "westernized" managerial class, and the convenience of opposite time zones (S. T. Cavusgil, G. Knight, \& J. R. Riesenberger, 2008a; CIA, 2012; Cullen \& Parboteeah, 2008; Economist, 2013a; Engardio, 2007; Makar, 2008).

Western firms are increasing their investments in India. The web version of the newspaper The Hindu recently reported that General Electric is investing \$200 million in Pune, which will be its first manufacturing facility in the country ${ }^{14}$. Through its joint venture with the Tata Global Beverages, Starbucks in 2013 opened its first stores in Mumbai and New Delhi. The Wall Street Journal reported that the initial plans were to invest $\$ 80$ million and open 80 stores in the country. The same article also wrote that Dunkin' Brands were planning to open 30 Dunkin' Donuts outlets together with its

${ }^{14}$ September 24, 2012: http://www.thehindu.com/business/global-firms-will-increaseinvestments-in-india-ge/article3932064.ece 
Indian partner by $2014 .{ }^{15}$ The Swedish giant retailer IKEA recently obtained approval by the Finance Ministry and plans to invest $\$ 1.75$ billion in as many as 25 new stores in the country. ${ }^{16}$ Following the recent relaxation of regulations on foreign (single brand) retailers in India, this would be the largest FDI (Foreign Direct Investment) by a foreign retailer ever recorded. ${ }^{17}$ These examples illustrate that foreign multinationals have an ongoing interest in getting established in India, either with manufacturing plants or with distribution and retail facilities to sell directly to the growing class of Indian consumers. India's continued economic growth, regulatory streamlining and improving infrastructure will increasingly make the country a more viable and less risky destination for sourcing and manufacturing. Foreign investors have to navigate both the federal and statewide mazes of rules, regulations, incentives and rivalries. Despite the potential long term benefits of doing business in India, sourcing from there can be a risky proposition. Mark Crone writes that the traditional three drivers of sourcing strategy cost, quality and service - now has a new important sibling: risk (Crone, 2006). Various risks are infiltrating supply chains, and sourcing and operating in India can present management with a multitude of challenges. It seems appropriate for us to research the particularities of the supply chain challenges experienced in India.

15 October 26, 2012:

http://online.wsj.com/article/SB10001424052970203922804578080072469407526.html

${ }^{16}$ http://online.wsj.com/news/articles/SB10001424127887323585604579008593008552768

17 November 19, 2012: http://ibnlive.in.com/news/finance-ministry-to-decide-on-ikeas-fdiproposal-on-tuesday/306324-7.html 


\section{CHAPTER 3: LITERATURE REVIEW AND CURRENT KNOWLEDGE}

Because this dissertation focuses on supply chain management risks in India, it is useful to provide appropriate definitions before we move on.

\section{a. Supply Chain Management}

A supply chain is a conceptual term for a string or network of companies from suppliers to end-users, with the intention of integrating supply and demand via coordinated company efforts (Frankel, Bolumole, Eltantawy, Paulraj, \& Gundlach, 2008). There are numerous, similar definitions of supply chain offered by many authors ${ }^{18}$ (for some examples, see Table 2). For the purposes of this research, the definition offered by the Council of Supply Chain Management Professionals will be used:

"Supply chain management encompasses the planning and management of all activities involved in sourcing and procurement, conversion, and all logistics management activities. Importantly, it also includes coordination and collaboration with channel partners, which can be suppliers, intermediaries, third party service providers, and customers. In essence, supply chain management integrates supply and demand management within and across companies"19.

18 (Canbolat, Gupta, Matera, \& Chelst, 2008; Cavinato, 2004; Chapman, Christopher, Jüttner, Peck, \& Wilding, 2002; Enyinda, Ogbuehi, \& Briggs, 2008; Frankel et al., 2008; Hallikas, Puumalainen, Vesterinen, \& Virolainen, 2005; Mangan et al., 2008; Ramsey \& Moffett, 2011; Ritchie \& Brindley, 2007; Sheffi, 2005; P. J. Singh, Smith, \& Sohal, 2005; Takahashi, 2012; Thun \& Hoenig, 2011).

${ }^{19}$ CSCMP's website: http://cscmp.org/aboutcscmp/definitions.asp 
Table 2: DEFINITIONS OF SUPPLY CHAIN, IN CHRONOLOGICAL ORDER

\begin{tabular}{|c|c|}
\hline Definition & Author \\
\hline $\begin{array}{l}\text { A network of interrelated entities that combine to } \\
\text { enable the satisfaction of customer demand. }\end{array}$ & (Chapman et al., 2002) p. 60 \\
\hline $\begin{array}{l}\text { The network of organizations that are involved, through } \\
\text { upstream and downstream linkages, in the different } \\
\text { processes and activities that produce value in the form } \\
\text { of products and services in the hands of the ultimate } \\
\text { consumer. }\end{array}$ & (Christopher \& Peck, 2004) p. 2 \\
\hline $\begin{array}{l}\text { The fundamental purpose of a supply chain is to match } \\
\text { supply with demand. }\end{array}$ & (Cohen \& Kunreuther, 2007) \\
\hline $\begin{array}{l}\text { Global supply chain refers to the firm's integrated } \\
\text { network of sourcing, production, and distribution, } \\
\text { organized on a worldwide scale and located in countries } \\
\text { where competitive advantage can be maximized. It } \\
\text { involves both upstream (supplier) and downstream } \\
\text { (customer) flows. }\end{array}$ & (Cavusgil et al., 2008b) p. 497 \\
\hline $\begin{array}{l}\text { A linked set of resources and processes that begins with } \\
\text { the sourcing of raw materials and extends through the } \\
\text { delivery of products and services to the end user across } \\
\text { the modes of transport. }\end{array}$ & $\begin{array}{l}\text { (ISO, 2011) } \\
\text { (International Organization for } \\
\text { Standardization) }\end{array}$ \\
\hline $\begin{array}{l}\text { Complex networks of different players, established with } \\
\text { core objectives to minimize the costs, maximize the } \\
\text { value and explore new markets through effectively } \\
\text { managed relationships between members. }\end{array}$ & $\begin{array}{l}\text { (Singhal, Agarwal, \& Mittal, 2011) } \\
\text { p. } 21\end{array}$ \\
\hline $\begin{array}{l}\text { A network of organizations possibly including suppliers, } \\
\text { manufacturers, logistics providers, } \\
\text { wholesalers/distributors, and retailers that aims to } \\
\text { produce and deliver products or services for the end } \\
\text { customer. }\end{array}$ & $\begin{array}{l}\text { (Manmohan S. Sodhi et al., 2012) } \\
\text { p. } 6\end{array}$ \\
\hline
\end{tabular}

Two of the definitions in Table 2 mention sourcing as an element of the supply chain. Sourcing is recognized as part of a set of activities named Supply Management. This term is broader than what was earlier referred to as Purchasing. The Institute of Supply Management (ISM) offers this definition: "The identification, acquisition, access, positioning, management of resources and related capabilities the organization needs or 
potentially needs in the attainment of its strategic objectives"20. Interestingly, "sourcing" is absent from this definition, as are the popular terms "procurement" and "purchasing". Burt et al. describe supply management as a five-step process consisting of identification of the need, identification of suppliers, establishing a price, establishing a purchase agreement, and finally managing the relationship with the chosen supplier (Burt, Petcavage, \& Pinkerton, 2010). Frankel et al. offer some historical perspective and a good compilation of definitions while describing the recent evolution from purchasing to supply management (Frankel et al., 2008). ISM lists this definition of "sourcing" in their online glossary: "(1) The process of identifying sources that could provide needed products or services for the acquiring organization; (2) The term used to reflect the entire purchasing process or cycle ${ }^{\prime 21}$. The process of identifying sources is not particularly risky or perilous. It is when the sourcing efforts result in ongoing supplier relationships that the buying organization is exposed to incremental hazards and risks. Table 3 lists four valid definitions of outsourcing.

You will notice that the third of the four definitions in Table 3 specifically includes production activities. This is an appropriate segue into the second and closely related functional focus of this dissertation, namely manufacturing and production activities in India. As mentioned, we are not particularly interested in the demand side of the supply chain, but both the sourcing and production sides are of concern. The

\footnotetext{
${ }^{20}$ https://www.ism.ws/Glossary/GlossaryTermDetail.cfm?TermID=2575

${ }^{21}$ http://www.ism.ws/Glossary/GlossaryTermDetail.cfm?TermID=2462
} 
main reason the demand side is not being targeted here is that those risks are deemed independent from the sourcing and manufacturing in India. Problems with constructing

Table 3: DEFINITIONS OF OUTSOURCING

\begin{tabular}{|l|l|}
\hline Definition & Author \\
\hline $\begin{array}{l}\text { A deliberate decision to have outsiders or strategic allies } \\
\text { perform certain activities in the value chain. }\end{array}$ & $\begin{array}{l}\text { (Cullen \& Parboteeah, 2008) p. } \\
225\end{array}$ \\
\hline $\begin{array}{l}\text { The use of professional, skilled, service-sector workers } \\
\text { located in countries other than that in which the firm is } \\
\text { domiciled. }\end{array}$ & (Deresky, 2008) p. 468 \\
\hline $\begin{array}{l}\text { The procurement of selected value-adding activities, } \\
\text { including production of intermediate goods or finished } \\
\text { products, from independent suppliers. Global sourcing [is] } \\
\text { the procurement of products or services from } \\
\text { independent suppliers or company-owned subsidiaries } \\
\begin{array}{l}\text { located abroad for consumption in the home country or a } \\
\text { third country. Offshoring refers to the relocation of a } \\
\text { business process or entire manufacturing facility to a } \\
\text { foreign country. }\end{array}\end{array}$ & $\begin{array}{l}\text { (Cavusgil et al., 2008b), 2008, } \\
\text { pages 266, 484 and 489 }\end{array}$ \\
\hline $\begin{array}{l}\text { Broadly, an activity may be organized in one of four } \\
\text { alternative ways: domestic outsourcing, offshore } \\
\text { outsourcing, domestic in-house, or offshore in-house. }\end{array}$ & (Gray, Roth, \& Leiblein, 2011) \\
\hline
\end{tabular}

reliable sales forecasts or predicting consumer demand patterns have little to do with

where the product is made. So we will exclude the demand side challenges and risks

from further analysis in this research. When we empirically survey supply chain

practitioners about their risk experiences, it is likely that they will provide answers that

reflect what they experience both on the supply side and the demand (downstream)

side, notwithstanding our preference to have them focus on the supply and production

side.

Returning to the realm of supply chain management, we now get a sense of the

human activities that go into the many steps of getting product from "dust to rust",

"farm to fork", "cradle to grave". The eight definitions in Table 4 give us a feel for the 
domain, including the lengthier CSCMP definition. "Management" is appropriately defined as "the process of guiding the development, maintenance, and allocation of resources to attain organizational goals" (Gitman \& McDaniel, 2009). Its four core activities consist of planning, organizing, leading and controlling. If they are done right, the company will benefit from organizational efficiency and effectiveness, and be able to achieve its mission and objectives (Gitman \& McDaniel, 2009).

Some of the seven definitions from Table 4 allude to the desirability of collaboration and coordination among the participants in the supply chain. Clusters of connected networks represent an extended enterprise perspective of supply chain management, providing us with an opportunity to impact the total system of interrelated companies for increased efficiency and effectiveness (J. J. Coyle, Langley, Novack, \& Gibson, 2013). Effectiveness is concerned with the extent to which company goals are accomplished. They usually include customer service measures such as leadtime, stock-out probability, and fill rates. Efficiency measures how well company resources are utilized, for which measures may include procurement, inventory and operating costs (Lai, Ngai, \& Cheng, 2002). The supply chain management challenge is to be effective in providing excellent customer service while keeping the overall costs down. 
Table 4: DEFINITIONS OF SUPPLY CHAIN MANAGEMENT (SCM)

\begin{tabular}{|c|c|}
\hline Definition & Author \\
\hline $\begin{array}{l}\text { The integration of key business processes from end user } \\
\text { through original suppliers that provides products, services, } \\
\text { and information that add value for customers and other } \\
\text { stakeholders. }\end{array}$ & $\begin{array}{l}\text { The Global Supply Chain Forum } \\
\text { (GSCF), as reported by (Lambert } \\
\text { \& Cooper, 2000) }\end{array}$ \\
\hline $\begin{array}{l}\text { The management of upstream and downstream } \\
\text { relationships with suppliers and customers in order to } \\
\text { create enhanced value in the final market place at less cost } \\
\text { to the supply chain as a whole. }\end{array}$ & (Christopher, 2002) p. 2 \\
\hline $\begin{array}{l}\text { SCM recognizes dependencies between firms. It has } \\
\text { achieved the status of a generic term for various } \\
\text { systematic processes that implicitly consider time- and } \\
\text { functional dependencies between firms' activities. }\end{array}$ & (Svensson, 2002) p. 116 \\
\hline $\begin{array}{l}\text { A multi-disciplinary and multi-functional set of activities } \\
\text { which deals not only with the more physical and tangible } \\
\text { attributes and activities (e.g. logistics), but equally the } \\
\text { more behavioural and intangible dimensions (e.g. } \\
\text { relationship building and management) }\end{array}$ & $\begin{array}{l}\text { (Ritchie \& Brindley, 2007) p. } \\
1401\end{array}$ \\
\hline $\begin{array}{l}\text { SCM is the integration and management of supply chain } \\
\text { organizations and activities through cooperative } \\
\text { relationships, effective business processes, and high levels } \\
\text { of information sharing to create high-performing value } \\
\text { systems that provide member organizations a sustainable } \\
\text { competitive advantage. }\end{array}$ & (Handfield, 2007) \\
\hline $\begin{array}{l}\text { SCM is interested in the coordination and collaboration of } \\
\text { processes and activities across functions within a network } \\
\text { of organizations. }\end{array}$ & (Olson, 2012) p. 12 \\
\hline $\begin{array}{l}\text { SCM encompasses the planning and management of all } \\
\text { activities involved in sourcing and procurement, } \\
\text { conversion, and all logistics management activities. } \\
\text { Importantly, it also includes coordination and } \\
\text { collaboration with channel partners, which can be } \\
\text { suppliers, intermediaries, third party service providers, } \\
\text { and customers. In essence, supply chain management } \\
\text { integrates supply and demand management within and } \\
\text { across companies. }\end{array}$ & $\begin{array}{l}\text { CSCMP, } 2012 \\
\text { (http://www.cscmp.org/about- } \\
\text { us/supply-chain-management- } \\
\text { definitions) }\end{array}$ \\
\hline $\begin{array}{l}\text { The management of material, information and financial } \\
\text { flows through the supply chain. It includes the } \\
\text { coordination and collaboration of processes and activities } \\
\text { across different functions such as marketing, sales, } \\
\text { production, product design, procurement, logistics, } \\
\text { finance, and information technology within the supply } \\
\text { chain. }\end{array}$ & $\begin{array}{l}\text { (Manmohan S. Sodhi et al., } \\
\text { 2012) p. } 6\end{array}$ \\
\hline
\end{tabular}


While it is quite clear that sourcing, procurement and materials management (the management of incoming supplies) are part of supply chain management, it may be a stretch to include production and manufacturing as activities under the purview of logistics and supply chain managers. As Coyle et al. point out, logistics, by its nature, focuses on processes that cut across traditional functional boundaries (J. J. Coyle et al., 2013). The supply chain interfaces and integrates with other functional areas such as marketing, manufacturing, operations, engineering, finance, accounting and human resources. Because the manufacturing or "conversion" processes are intensely dependent on input from the supply chain function, it makes sense for this research to study risks not just isolated to the logistics activities of a firm, but in a more integrative perspective that includes the manufacturing functions. The coupling between supply chain activities and manufacturing is so close that disturbances will tend to affect both. Nevertheless, we will not attempt to uncover or analyze disruptions that may occur solely as a result of manufacturing operations. For example, we will not be concerned with machine breakdowns (a manufacturing problem) unless they are caused by insufficient power supply or poor raw materials (supply chain problems).

Most risks that affect the supply chain, i.e. supply chain management risks, should squarely belong within the domain of the supply chain managers. Supply chain leaders cannot walk away from trouble as soon as disruptions inevitably happen, and they cannot customarily rely on other mechanisms and structures within the firm ${ }^{22}$ to

\footnotetext{
${ }^{22}$ For example, enterprise risk systems, security systems, procedures and personnel, insurance coordinators, etc.
} 
rectify perilous situations or provide safety nets. Generally, if the risks originated with the supply chain, they belong in the supply chain and should be handled primarily by supply chain people. ${ }^{23}$ We remarked earlier that the act of management consists of the four main activities of planning, organizing, leading and controlling. It would make sense that an awareness of risks should permeate and shape how managers think and act throughout the execution of these four activities. When supply chain managers formulate strategies, policies and operating procedures, risks and how to control them must be constantly in the back of their minds.

\section{b. Supply Chain Risks}

This part of the presentation will discuss the three concepts of risk, supply chain risk, and supply chain risk management. The dissertation will eventually arrive at a discussion of risks encountered when sourcing overseas, and particularly in India. An extensive literature review and the ensuing survey of supply chain professionals working in India will help us uncover and identify the specific risks experienced in India, their impacts and which methods practitioners find are useful in mitigating them.

\section{Stage 1: Risk}

The 2003 version of Guinness World Records features the highest fall survived without a parachute: In 1972, a Yugoslavian air stewardess survived a 33,000 foot fall after a midair airplane explosion (Folkard, 2003) ${ }^{24}$. Despite this miraculous story, the

\footnotetext{
${ }^{23}$ As we will see, there are of course exceptions to this. Many risk scenarios are serious enough to engage the entire organization, and they can potentially damage a lot more than just the supply chain.

${ }^{24}$ The author remembers this story. Supposedly the survivor was using the lavatory when it happened, and this encapsulated unit landed on a long and snowy slope that softened the impact.
} 
example of jumping from an airplane without a parachute has been used as an illustration of something totally risk "free": You are $100 \%$ certain to die, so there is no risk involved (Holton, 2004). Risk $\neq$ Certainty. Certainty also implies $100 \%$ probability and absolutely no variability of outcomes. Table 5 lists several definitions of risk by authors and thinkers both outside and inside the world of supply chain management. The three terms (bold print) that repeat themselves are 1) Probability ${ }^{25}$; 2) Variability ${ }^{26}$; and 3) Uncertainty ${ }^{27}$. Probability is a measure of relative frequency of an event and is limited within a range from zero (no chance) to one (certainty) (Waner \& Costenoble, 2007). Some probabilities are objectively determined; for example a fair coin toss has a probability of 0.5 (or $50 \%$ ) of landing on heads. Most other probabilities are subjectively determined: $60 \%$ chance of rain tomorrow; $90 \%$ certain that the company will meet its profitability target; between $90 \%$ and $100 \%$ probability that a magnitude 5 or higher earthquake will hit the Puget Sound region over the next 100 years $^{28}$. Although such estimates are often made by scientists and government agencies, they are still subjective probabilities that may be based on what the estimator knows and a combination of educated guessing, statistics, various forecasting and simulation techniques, and rounding. As Holton points out, probability quantifies perceived uncertainty, meaning that most probability assessments are based on incomplete information and possible ignorance of the "unknown unknowns"29 (Holton, 2004).

${ }^{25}$ Acceptable acronyms for probability are chance and likelihood.

${ }^{26}$ Acceptable acronyms for variability are fluctuations, variation and variance.

${ }^{27}$ An acceptable acronym for uncertainty is unpredictability.

${ }^{28}$ http://eqint.cr.usgs.gov/eqprob/2002/out/image.24079.jpg

${ }^{29} \mathrm{~A}$ statement most recently attributed to former Secretary of Defense Donald Rumsfeld. 
Table 5: DEFINITIONS OF RISK

\begin{tabular}{|c|c|}
\hline Definition & Author \\
\hline $\begin{array}{l}\text { Usually if the term "yield" were replaced by "expected } \\
\text { yield" or "expected return", and "risk" by "variance of } \\
\text { return", little change of apparent meaning would result. }\end{array}$ & (Markowitz, 1952) p. 89 \\
\hline $\begin{array}{l}\text { The threat of injury, damage or loss, a dangerous } \\
\text { element or factor, or the chance of loss. }\end{array}$ & (Merriam-Webster, 1976) \\
\hline $\begin{array}{l}\text { Explicit recognition of the [known] probabilities of } \\
\text { events outside the decision maker's control. }\end{array}$ & (Cleland \& Kocaoglu, 1981) p. 308 \\
\hline $\begin{array}{l}\text { Risk is always relative to the observer. It is subjective } \\
\text { just as is probability itself. It depends on what the } \\
\text { observer knows. }\end{array}$ & (Kaplan \& Garrick, 1981) p. 22 \\
\hline $\begin{array}{l}\text { Risk is an set of triplets; } R=\left[\left(s_{i}, p_{i}, x_{i}\right)\right], i=1,2, \ldots, N \text {, } \\
\text { where } s_{i} \text { is a scenario identification or description, } p_{i} \text { is } \\
\text { the probability of that scenario; and } x_{i} \text { is the } \\
\text { consequence or evaluation measure of that scenario, } \\
\text { i.e. the measure of damage. }\end{array}$ & (Kaplan \& Garrick, 1981) p. 13 \\
\hline $\begin{array}{l}\text { Reflecting variation in the distribution of possible } \\
\text { outcomes, their likelihoods, and their subjective values. }\end{array}$ & (March \& Shapira, 1987) p. 1404 \\
\hline $\begin{array}{l}\text { Risk has become increasingly a term referring not to the } \\
\text { unpredictability of outcomes but to their costs, } \\
\text { particularly their costs in terms of mortality and } \\
\text { morbidity. }\end{array}$ & (March \& Shapira, 1987) p. 1411 \\
\hline $\begin{array}{l}\text { Risk refers to variation in corporate outcomes or } \\
\text { performance that cannot be forecast ex ante. } \\
\text { Unpredictability in corporate outcome variables. }\end{array}$ & (Miller, 1992) p. 311 and p. 312 \\
\hline $\begin{array}{l}\text { The extent to which there is uncertainty about whether } \\
\text { potentially significant and/or disappointing outcomes of } \\
\text { decisions will be realized. }\end{array}$ & (Sitkin \& Pablo, 1992) p. 9 \\
\hline $\begin{array}{l}\text { The probability that a particular adverse event occurs } \\
\text { during a stated period of time, or results from a } \\
\text { particular challenge. As a probability in the sense of } \\
\text { statistical theory, risk obeys all the formal laws of } \\
\text { combining probabilities. }\end{array}$ & (Royal_Society, 1992) \\
\hline $\begin{array}{l}\text { The elements of the risk construct are a) potential } \\
\text { losses, b) significance of those losses, and c) the } \\
\text { uncertainty of those losses. }\end{array}$ & $\begin{array}{l}\text { (V.-W. Mitchell, 1995; Yates \& } \\
\text { Stone, 1992) }\end{array}$ \\
\hline $\begin{array}{l}\text { The risk of any particular type of loss is a combination } \\
\text { of the probability of that loss and the significance of } \\
\text { that loss to the individual or organization. }\end{array}$ & (V.-W. Mitchell, 1995) p. 116 \\
\hline $\begin{array}{l}\text { The uncertainty component of risk stems from } \\
\text { imperfect knowledge. }\end{array}$ & (V.-W. Mitchell, 1995) p. 116 \\
\hline $\begin{array}{l}\text { The risk of any particular type of loss is a combination } \\
\text { of the probability of that loss } P \text { (Loss } n \text { ) and the } \\
\text { significance of that loss to the individual or }\end{array}$ & (V.-W. Mitchell, 1995) p. 116 \\
\hline
\end{tabular}




\begin{tabular}{|c|c|}
\hline $\begin{array}{l}\text { organization, I }\left(\text { Loss }_{n}\right) \text {. Therefore, } \text { Risk }_{n}=P\left(\text { Loss }_{n}\right) \times I \\
\left(\text { Loss }_{n}\right)\end{array}$ & \\
\hline $\begin{array}{l}\text { A chance of danger, damage, loss, injury, or any other } \\
\text { undesired consequences. }\end{array}$ & $\begin{array}{l}\text { (Harland, Brenchley, \& Walker, } \\
\text { 2003) }\end{array}$ \\
\hline The probability of variance in an expected outcome. & (Spekman \& Davis, 2004) p. 416 \\
\hline Vulnerable; likely to be lost or damaged. & (Christopher \& Peck, 2004) p. 3 \\
\hline $\begin{array}{l}\text { Risk is perceived to exist when there is a relatively high } \\
\text { likelihood that a detrimental event can occur and that } \\
\text { event has a significant associated impact or cost. }\end{array}$ & $\begin{array}{l}\text { (Zsidisin, Ellram, Carter, \& } \\
\text { Cavinato, 2004) p. } 397\end{array}$ \\
\hline $\begin{array}{l}\text {...Knight's famous definition of risk. Risk relates to } \\
\text { objective probabilities. Uncertainty relates to } \\
\text { subjective probabilities. }\end{array}$ & $\begin{array}{l}\text { (Holton, 2004) p. } 20 \text { (referring to } \\
\text { Frank Knight's } 1921 \text { book) }\end{array}$ \\
\hline $\begin{array}{l}\text { Risk, then, is exposure to a proposition of which one is } \\
\text { uncertain. ...we can never operationally define risk. At } \\
\text { best, we can operationally define only our perception of } \\
\text { risk. }\end{array}$ & (Holton, 2004) p. 22 and p. 24 \\
\hline $\begin{array}{l}\text { Risk is calculable; it can be expressed in terms of odds. } \\
\text { Uncertainty is incalculable. }\end{array}$ & (Nohria, 2006) \\
\hline The expected outcome of an uncertain event & (Manuj \& Mentzer, 2008b) p. 196 \\
\hline $\begin{array}{l}\text { A common sense definition of risk - acknowledged by } \\
\text { the International Organization for Standardization (ISO, } \\
\text { 2002) - mainly deals with two of its essential } \\
\text { components: losses (along with related amounts) and } \\
\text { uncertainty of their occurrence. }\end{array}$ & (McCormack et al., 2008) p. 6 \\
\hline $\begin{array}{l}\text { The fluctuations (variability) around the expected value } \\
\text { (mean) of a measure. }\end{array}$ & (Wagner \& Bode, 2009) p. 6 \\
\hline $\begin{array}{l}\text { A situation is risky when it entails exposure to two } \\
\text { essential components: exposure to an event and the } \\
\text { uncertainty of possible outcomes - both of which are } \\
\text { necessary in completing a risky situation. }\end{array}$ & (Rao \& Goldsby, 2009) p. 100 \\
\hline Risk $=f($ Threat, Vulnerability, Consequence) & (TSA, 2010) \\
\hline $\begin{array}{l}\text { Fluctuations which cannot be predicted precisely and } \\
\text { change their nature, impact and occurrence over time. }\end{array}$ & (Singhal et al., 2011) p. 21 \\
\hline
\end{tabular}

The first entry in Table 5 exemplifies the financial interpretation of variability, and combined with Wagner \& Bode's (2009) more statistically derived statement towards the end of the same table, we get a sense that risk occurs when there is possible variability of future outcomes. Risk, in short, is that the reality might be different than what we prepared for. In the Capital Asset Pricing Model ("CAPM"), the variability of an asset's historical returns are divided into a systematic portion (returns 
that co-varies with the market return) and a nonsystematic (residual) portion that can be called the specific risk (March \& Shapira, 1987). Financial theory will penalize assets with highly variable returns by demanding a higher rate of return, or risk premium. The main rationale for this is found in utility theory, where decision makers (managers) display preferences for certain outcomes (Baird, 1989). Most decision makers are risk averse, implying that they want a premium (higher expected return) if they are to take on a wider range of possible outcomes ${ }^{30}$. Variability (or volatility) compared to a benchmark standard ${ }^{31}$ makes managers uncomfortable, and this has a price. Financial portfolio managers strive to create optimal mixtures of assets - yielding high returns with low risk - by combining investments with different attributes and performances. Supply chain managers aim for similar risk reduction by diversifying sources and taking steps to spread the exposure (Eule, 2012). Trkman and McCormack are touching upon this issue when they discuss supplier portfolio management in a 2009 paper (Trkman \& McCormack, 2009). They sorted suppliers into four categories ${ }^{32}$ depending on how they perform under endogenous and exogenous uncertainty, and concluded that the most desirable supplier mix depends on the operating environment of the supply chain leader, its strategy and the type of supply chain involved. They clearly endorsed using dual or multiple sourcing strategies, choosing suppliers with different performance

\footnotetext{
${ }^{30}$ Their risk preferences create a concave preference curve, where preference is plotted vis-à-vis monetary value or outcome.

${ }^{31}$ In the U.S. stock market, the benchmark is typically the S\&P 500 index, and stocks with a low variability compared to this (i.e. a "beta" below one) are considered low risk.

32 'Rocks', 'Stars', 'Millstones' and 'Bouncers' (e.g. the Stars perform well in turbulent environments)
} 
characteristics (recall financial "betas"). Aydin et al. write about decentralized supply risk management, where to reduce overall supply risks ${ }^{33}$ they recommend finding and developing non-correlated suppliers to make use of diversification. They see benefit in dividing the suppliers into clusters to enjoy the fruits of both supplier competition and diversification (Aydin, Babich, Beil, \& Yang, 2012). Adding to this type of positive thinking regarding risk, Richard de Neufville, in a paper about real options, encourages us to understand that uncertainty is not always a risk to be avoided, as it also presents valuable opportunities that can be exploited (Neufville, 2003). He encourages managing the risks instead of avoiding them. In that respect, real options theory ${ }^{34}$ underpins the claim that to build decisive advantage, a company must be faster at generating options and realigning resources than its competitors (Ponomarov \& Holcomb, 2009). In supply chain management, there seems to be similarities with financial management.

Several authors have suggested that companies should view supplier risk in much the same way as financial institutions look at investor or investment risks, meaning that a higher level of risk requires a higher level of reward to assume those risks (Favre \& McCreery, 2008). While it may be useful to use applications from financial risk management, supply chains present other types of risks, including the possibility of personal injury and property damage. Such safety issues can make it unethical and often unthinkable to tinker with the risk and reward relationship.

33 The three supply risks they highlight are 1) Shortage of critical parts or loss of supplier capacity; 2) Loss of finished goods inventory due to use of defective parts; and 3) Inflated supply costs

${ }^{34}$ Real options theory stipulates that systems are built flexible enough so that they can adapt to changing conditions, new strategies and changing environments. The structure gives the manager the option to choose alternative paths under ways. Having real options builds resilience into a system. 
Some academic articles attempt to optimize supplier networks by applying mathematical or statistical tools for trade-off analyses among metrics such as expected costs, quality acceptance levels and on-time delivery distributions. Wu and Olson authored a 2008 paper where they compared three different quantitative models: chance constrained programming (CCP), data envelopment analysis (DEA) and multiobjective programming (MOP), combined with (Monte Carlo) simulations for all three methods. Such methods can serve as useful tools to evaluate and improve supplier selection decisions in uncertain supply chain environments (Wu \& Olson, 2008).

Uncertainty is the third term that kept appearing in Table 5: Definitions of Risk. Some writers - notably Frank Knight - have attempted to separate risk from uncertainty by characterizing risk as measurable and uncertainty as unmeasurable, so that risk relates to objective probabilities and uncertainty relates to subjective probabilities (Holton, 2004). In this view, risk is calculable; it can be expressed in terms of odds, while uncertainty is incalculable (Nohria, 2006). This view of risk is quite ambitious, as it requires known probability distributions of possible outcomes. However, as Vilko et al. point out, the cases when probability distributions cannot be defined are much more common than those where probability distributions are known (Vilko, Edelmann, \& Hallikas, 2010).

It seems the literature is moving away from a strict interpretive separation between risk and uncertainty, and the two terms are often used interchangeably, or conjunctively, as in "risk occurs because there is uncertainty about the future" (Waters, 2011). Another take on this is that "the uncertainty component of risk stems from 
imperfect knowledge" (V.-W. Mitchell, 1995). Regardless of whether risk is part of uncertainty or vice versa, we are more interested in how risks and uncertainties can hurt supply chain operations.

The notion of risk involves both uncertainty and some kind of loss or damage that might be incurred. Kaplan and Garrick express this as risk = uncertainty + damage (Kaplan \& Garrick, 1981). This effectively cuts out the possible positive effects of risk, and limits our concern to risks that cause loss or damage. For our purposes, Culp's definition that risk can be defined as any source of randomness that may have an adverse impact on a person or corporation is useful (McCormack et al., 2008), as well as other descriptions that only cover the negative sides of risk: losses, disruptions, untoward situations, glitches, damage, hazards, disturbances, costs, etc.

Lastly, for any uncertain outcome to have a possibility of hurting us, we need to have exposure to or an interest in what might transpire. Risk, then, entails not only uncertainty, but also exposure, leading to Holton's definition: Risk is exposure to a proposition of which one is uncertain (Holton, 2004). Kent Miller offers a slightly different interpretation by stating that exposure refers to the sensitivity of a firm or project's cash flows to changes in any of a number of interrelated uncertain variables (Miller, 1992). According to Kaplan and Garrick, a risk analysis consists of answers to the following three questions, also dubbed their "set of triplets" (Kaplan \& Garrick, 1981):

1) What can happen, i.e. what can go wrong?

2) How likely is it that it might happen?

3) What are the consequences (impact) if it happens? 
This division into Scenario, Likelihood and Consequence can be used to calculate a risk distribution curve, where the risk that the organization faces is the whole curve. So to answer the question "what is the risk", a single number is not enough to communicate the idea of risk. As Kaplan and Garrick write, "It takes a whole curve". Similarly, risk can be defined as a collection of pairs of likelihood $(\mathrm{L})$ and outcomes ${ }^{35}(\mathrm{O})$, so that Risk $=\left[\left(L_{1}, O_{1}\right),\left(L_{2}, O_{2}\right), \ldots . .\left(L_{n}, O_{n}\right)\right]$ where each 2-tuple is a possible scenario (McCormack et al., 2008). The alternative to the distribution curve concept is the point concept of risk, which combines the probability of a particular type of loss with the significance (impact) of that loss to the organization: Risk $n=P\left(\operatorname{Loss}_{n}\right) \times I\left(\operatorname{Loss}_{n}\right)($ V.-W. Mitchell, 1995). To get an accurate depiction of the risk theatre, the whole distribution curve needs to be known. Many unacceptable and unpalatable risks can hide behind midpoints such as expected values and averages.

It is crucial for a company to determine whether it is truly exposed to any of the possible risks or hazards that exist. It becomes important to know whether its perception of exposure is commensurate with the risk level (sets of likelihoods multiplied by impacts) that can be anticipated. As Holton points out, there is no true risk because everything is a matter of perception. He claims we can at best only operationalize our perception of risk, and that is what we use to develop metrics and risk assessments, subjective as they may be (Holton, 2004). Experienced managers will learn to discern exaggerated anxieties and worries from more objectively derived and

\footnotetext{
${ }^{35}$ Outcomes are the same as impacts.
} 
cool-headed assessments of exposure and risk. Organizations are not vulnerable to every possible risk that may exist. Contrary to what the public may think, the instances of piracy in the Gulf of Aden are not a major threat to the integrity of the global transportation system. However, it is a real concern to the shipping lines trafficking that particular stretch of water. Risk identification and assessment is ultimately a very particular and individual endeavor.

\section{Stage 2: Supply Chain Risk}

Because risk is a product of exposure and uncertainty (Holton, 2004), one can conceptualize exposure as being inherent in the firm's nature ${ }^{36}$, while the uncertainty comes from the broader environment in which the firm is operating. In a systems sense, there is also a dynamic interplay between a firm's exposure and how it responds to its environment, and how the environment responds to the firm's exposure ${ }^{37}$. A firm's exposure to a disruptive event will influence how vulnerable it is to such an event (or scenario), as the firm's vulnerability to a disruptive event can be viewed as a combination of the likelihood of a disruption and its potential severity (Sheffi, 2005). Exposure makes a firm vulnerable to disruptions. There is agreement among supply chain academics and practitioners that over the past few decades, vulnerability of supply chains to disturbances or disruptions has increased (Christopher, 2002;

Christopher \& Lee, 2004; Kotabe \& Murray, 2004; S. Wagner \& C. Bode, 2006). The main

${ }^{36}$ Including its attributes such as business model, strategies, asset base, location, industries served, ownership structure, product range, management style, corporate culture, history, etc.

${ }^{37}$ Case in point: a well-guarded and protected warehouse is less likely to be a target for burglars or intruders. 
reasons for this increased vulnerability can be traced to three main and somewhat

intertwined factors:

1. Increased competitive pressures: This lead to efforts to make processes and supply chains both more efficient and more effective (responsive). Efficiencies were achieved by making supply chains leaner, which implied lower inventories and quicker turnaround times. Many firms switched to single sourcing of crucial supplies. Customer responsiveness was improved by better quality control, faster to market, better selection, higher fill rates and shrinking product life cycles. (Melnyk, Ragatz, \& Zsidisin, 2005). To stay relevant, firms were forced to embrace operational efficiencies.

2. Accelerated globalization of markets: Globalization made it easier to find cheaper sources overseas, and with both suppliers and customers in foreign markets, the supply chains experienced longer freight routes and longer lead times, in addition to various cultural and communications snags. Global supply chains have more delay points and greater uncertainties (Manuj \& Mentzer, 2008a; Vanderspek, 2012).

3. Increased inter-firm dependencies: The trend is towards increased collaboration within the supply chain networks to achieve better visibility and distribution accuracy. These couplings up and down the supply chain have created greater mutual dependencies and sensitivities.

The three factors have contributed to increasing the complexity of modern, global supply chains (ScienceWatch, 2011). In a network sense, the many new nodes, links, relationships and interactions have created supply chains that are vulnerable to a variety of internal and external disruptions and hiccups. Complexity of a supply chain can also more simply be defined as the sum of two components: the total number of nodes and the total number of forward, backward and within-tier materials flows within a given supply chain (Craighead, Blackhurst, Rungtusanatham, \& Handfield, 2007). As has been argued, accidents arise from systems, and they are inevitable if these systems are complex and tightly coupled (de_Koster, Stam, \& Balk, 2011; Perrow, 1999a, 1999b). Perrow's "Normal Accident Theory" holds that accidents become inevitable or normal in 
complex, tightly coupled technological systems (Perrow, 1999a; S. M. Wagner \& C.

Bode, 2006) $)^{38}$. Low visibility, tight couplings and a lack of slack could be detrimental to resilience, where resilience is defined as the ability to recover quickly from disturbances $\left(\right.$ Sheffi, 2005) ${ }^{39}$. Supply chain visibility is defined roughly as availability of and access to relevant data (O. Khan \& Zsidisin, 2012). Visibility reveals a bigger piece of the big picture, and allows for better planning and decision making. It entails having access to sales and production forecasts and inventory levels of both suppliers and customers, as well as updated information on availability of logistics resources (transportation and warehouse capacity, etc.) ${ }^{40}$ While lack of visibility is not strictly a risk, it is a deficiency in a defensive mechanism that healthy supply chains should possess.

There are many benefits to reshaping the supply chain structures and practices to make them more efficient and effective, but many authors point out that these efforts have made them more susceptible to risks in the business environment ( $S$. Wagner \& C. Bode, 2006). Modern supply chain management and the adoption of lean principles have resulted in "system fragility", according to Melnyk et al. Waste reduction strategies such as buffer reductions ${ }^{41}$ have led to a state where companies

\footnotetext{
${ }^{38}$ Complex systems imply complex interactions within the supply chain and between the supply chain and its environment (Speier, Whipple, Closs, \& Voss, 2011)

${ }^{39}$ A more elaborate definition is "the supply chain's ability to cope with the consequences of unavoidable risk events in order to return to its original operations or move to a new, more desirable state after being disturbed" (Christopher \& Peck, 2004; Jüttner \& Maklan, 2011).

${ }^{40}$ In classic information theory, the availability of information cuts down on uncertainty. For management purposes (planning, organizing, control), access to good information (through, for example, greater visibility) certainly helps in assessing the situation and making better decisions (Denning \& Bell, 2012)

${ }^{41}$ There are typically three types of buffers: safety stock, extended lead times and excess capacity (Melnyk et al., 2005)
} 
have less control over their operations and are less able to respond to disruptions. In stable and predictable markets these powerful tools for making operations leaner and more efficient are quite effective, but they have created more fragile supply chains that appear less resilient when faced with risks and disruptive events (Melnyk et al., 2005). Waters confirms this by stating that removing slack in the supply chain is creating inflexible chains where even small and unexpected events can bring everything to a standstill (Waters, 2011). Through surveying 760 German companies, Wagner and Bode were able to empirically show that several structural variables of supply design ${ }^{42}$ were relevant for a firm's exposure to supply chain risk. These supply chain design variables amplified a firm's exposure to risk (S. Wagner \& C. Bode, 2006). In their survey of German auto industry executives, Thun and Hoenig asked them to rank seven drivers of supply chain risk (Thun \& Hoenig, 2011). Globalization came out first, followed by product variety, outsourcing, reduction of suppliers, focus on efficiency, central distribution and centralized production.

Disruption risks are caused by events that create a supply shortage for certain durations (Haksöz \& Arslan, 2012). Disruptions can vary from everyday annoyances such as incoming deliveries that are late by a few hours to major catastrophic events that in the worst case might not only hurt people and the environment, but also force the company out of business. Just by reading the daily newspapers, one can easily find headlines announcing yet another supply chain disaster somewhere in the world. As this

${ }^{42}$ Such as the firm's degree of dependence on certain suppliers or customers, the degree of single sourcing or reliance on global supply sources. 
was written, the U.S. East Coast experienced Sandy - one of the worst hurricanes and floods in history; a generic Lipitor cholesterol drug produced in India was recalled because of findings of glass particles in the capsules, and a factory fire in Bangladesh killed more than 140 textile workers. ${ }^{43}$ The New York Times reported on January 23, 2013 that since 2005, factory fires in Bangladesh have killed 600 workers. A few months later, a Dhaka garment factory building collapsed, killing more than 1,100 workers.

Disruptions can be either internal or external to the focal supply chain, and they can be either caused by nature or by human actions. Table 6 lists definitions of supply chain risk by recognized authors in the field. In the spirit of the "triple bottom line" 44 , we appreciate definitions that mention negative consequences to people and the environment, in addition to the obvious profit degradation. With the possible exception of Harland et al.'s definition, the dozen variations in Table 6 do not contain direct references to these big picture risks, and only Zsidisin specifically mentions "threats to customer life and safety". From a financial standpoint, it is likely that any disaster that causes loss of life or environmental damage will ultimately be costly for a business and affect the bottom line, but when we define supply chain risks, a more deliberate and balanced mention of the non-financial outcomes seems reasonable. ${ }^{45}$ This view is

${ }^{43}$ After the November 2012 Bangladesh factory fire (following a similar fire just a few months earlier in Karachi, Pakistan), commentators pointed out that "low prices can have high costs". Favre and McCreery noted that "low dollar spend suppliers can be a source of significant risk exposure" (Favre \& McCreery, 2008)

${ }^{44}$ Or the popularly labeled 3 P's: People, Planet and Profit

${ }^{45}$ Sadly, people were still perishing from the after-effects of the November 2012 hurricane Sandy when several press commentators chirped in that this disaster would be "good for business". They were referring to greater sales of building materials and more work for contractors. 
Table 6: DEFINITIONS OF SUPPLY CHAIN RISK

\begin{tabular}{|c|c|}
\hline Definition & Author \\
\hline $\begin{array}{l}\text { A variation in the distribution of possible supply chain } \\
\text { outcomes, their likelihood, and their subjective value. }\end{array}$ & $\begin{array}{l}\text { (Jüttner, Peck, \& Christopher, 2003) } \\
\text { building on (March \& Shapira, } \\
\text { 1987) p. } 1404\end{array}$ \\
\hline $\begin{array}{l}\text { Any risks for the information, material and product } \\
\text { flows from original supplier to the delivery of the final } \\
\text { product for the end user. In simple terms, supply chain } \\
\text { risks refer to the possibility and effect of a mismatch } \\
\text { between supply and demand. }\end{array}$ & (Jüttner et al., 2003) p. 7 \\
\hline $\begin{array}{l}\text { Chance of danger, damage, loss, injury or any other } \\
\text { undesired consequences. }\end{array}$ & (Harland et al., 2003) p. 52 \\
\hline $\begin{array}{l}\text { The essence of most disruptions is a reduction in } \\
\text { capacity and therefore inability to meet demand. }\end{array}$ & (Sheffi, 2005) p. 14 \\
\hline $\begin{array}{l}\text { Unplanned and unanticipated events that disrupt the } \\
\text { normal flow of goods and materials within a supply } \\
\text { chain, and, as a consequence, expose firms within the } \\
\text { supply chain to operational and financial risks. }\end{array}$ & (Craighead et al., 2007) p. 132 \\
\hline $\begin{array}{l}\text { The distribution of performance outcomes of interest } \\
\text { expressed in terms of losses, probability, speed of } \\
\text { event, speed of losses, the time for detection of the } \\
\text { events, and frequency. }\end{array}$ & (Manuj \& Mentzer, 2008b) p.197 \\
\hline $\begin{array}{l}\text { The combination of ( } 1 \text { ) an unintended, anomalous } \\
\text { triggering event that materializes somewhere in the } \\
\text { supply chain or its environment, and ( } 2 \text { ) a } \\
\text { consequential situation which significantly threatens } \\
\text { normal business operations. }\end{array}$ & (Wagner \& Bode, 2008) p. 309 \\
\hline $\begin{array}{l}\text { Supply chain disruption: An unintended, untoward } \\
\text { situation. For the affected firms, it is an exceptional and } \\
\text { anomalous situation in comparison to every-day } \\
\text { business. }\end{array}$ & (McCormack et al., 2008) p. 6 \\
\hline $\begin{array}{l}\text { Risks can be classified into Source Risks, Make Risks, } \\
\text { Deliver Risks, and Return Risks. }\end{array}$ & (McCormack et al., 2008) p. 22 \\
\hline $\begin{array}{l}\text { Deviation from the expected value of a supply chain } \\
\text { performance objective resulting in negative } \\
\text { consequences for the affected firm. }\end{array}$ & (Wagner \& Bode, 2009) p. 5 \\
\hline $\begin{array}{l}\text { The negative outcome resulting from adverse events } \\
\text { that occur in supply chains, logistics networks, and } \\
\text { transportation operations. }\end{array}$ & (Wagner \& Bode, 2009) p. 5 \\
\hline $\begin{array}{l}\text { Risk is the potential to lose time and money or other- } \\
\text { wise not be able to accomplish an organization's goals. }\end{array}$ & (Gitman \& McDaniel, 2009) p. 4 \\
\hline $\begin{array}{l}\text { Operational risks and disruptions: Operational risks } \\
\text { involve inherent uncertainties for SC elements such as } \\
\text { customer demand, supply and cost. Disruption risks } \\
\text { come from disasters (natural and man-made) and from } \\
\text { economic crises. }\end{array}$ & (Olson, 2012) p. 13 \\
\hline
\end{tabular}


supported by Carter and Rogers, who in 2008 defined supply chain risk management as "the ability of a firm to understand and manage its economic, environmental, and social risks in the supply chain" (Carter \& Rogers, 2008).

Supply management refers to the upstream activities of sourcing and procurement, so it makes sense to include some alternative definitions of "supply risk" (as opposed to "supply chain risk"):

Table 7: DEFINITIONS OF SUPPLY RISK

\begin{tabular}{|l|l|}
\hline Definition & Author \\
\hline $\begin{array}{l}\text { The probability of an incident associated with inbound } \\
\text { supply from individual supplier failures or the supply } \\
\text { market occurring, in which its outcomes result in the } \\
\text { inability of the purchasing firm to meet customer } \\
\text { demand or cause threats to customer life and safety. }\end{array}$ & \\
\hline $\begin{array}{l}\text { Involving the potential occurrence of events } \\
\text { associated with inbound supply that can have } \\
\text { significant detrimental effects on the purchasing firm. }\end{array}$ & (Zsidisin, 2003b) \\
\hline Threats to supply continuity. & (Melnyk et al., 2005) \\
\hline $\begin{array}{l}\text { Supply risk is the uncertainty associated with supplier } \\
\text { activities and in general supplier relationships, i.e. the } \\
\text { transpiration of significant and/or disappointing } \\
\text { failures with inbound goods and services. }\end{array}$ & (Jüttner, 2005), and (Zsidisin, Panelli, \\
\hline $\begin{array}{l}\text { Risk related to a given supplier's characteristics } \\
\text { evolves from the deviation between the level of } \\
\text { manufacturer expectation and the actual supplier } \\
\text { performance. }\end{array}$ & (Levary, 2007) p. 392 \\
\hline $\begin{array}{l}\text { The distribution of outcomes related to adverse } \\
\text { events in inbound supply that affect the ability of the } \\
\text { focal firm to meet customer demand (in terms of both } \\
\text { quantity and quality) within anticipated costs and } \\
\text { time, or causes threats to customer life and safety }\end{array}$ & $\begin{array}{l}\text { (Manuj \& Mentzer, 2008b) p. 197, } \\
\text { building on (Zsidisin, 2003a) }\end{array}$ \\
\hline $\begin{array}{l}\text { Those risks associated with the sourcing of products } \\
\text { by a focal firm. }\end{array}$ & $\begin{array}{l}\text { (Christopher, Mena, Khan, \& Yurt, } \\
\text { 2011) p. 67 }\end{array}$ \\
\hline
\end{tabular}

Although the definition by Manuj \& Mentzer in Table 7 takes into account the customers and their well-being, we can think of costly risks and disruptions that do not necessarily trickle all the way down to the customer. Many everyday annoyances and 
delays can be costly and expensive to remedy, but they do not necessarily incapacitate the firm's ability to make deliveries and meet demand. Left unchecked, the many imperfections and inefficiencies in supply management will cause the overall cost level to rise over time, but firms are often able to satisfy demand regardless ${ }^{46}$. Risk management, then, becomes an effective method to help reduce the chaos.

Levary's definition from Table 7 is interesting from a risk theory standpoint. Risk occurs when there is a deviation between what is expected and what is experienced. What is expected should already be taken care of (discounted) through the company's regular management practices, and risk is encountered when something unexpected happens. Perhaps many of the everyday annoyances are to be expected, in which case they should be remedied through sound and regular management practices. Most low level disruptions can be dealt with as part of business as usual (Glendon, 2012). In supply chain risk management, if we can disregard many pedestrian disruptions that are bound to happen, the focus becomes on identifying, assessing, mitigating and controlling disruptions with probability and frequency, but with significant impact on the company's operations, the environment and human safety. Adam Prakash puts it this way: "...unpredictable changes - or "shocks" - are of primary concern. When shocks surpass a certain critical size or threshold and persist at those levels, traditional policy prescriptions and coping mechanisms are likely to fail" (Prakash, 2011).

${ }^{46}$ Undoubtedly, sloppy management practices can over time contribute to "death by a thousand cuts", so attention has to be paid to supply chain annoyances. Blake Johnson calls these "garden-variety business uncertainty" that needs to be dealt with (B. Johnson, 2012). 
It is a plausible assumption that money can be made on a sustained basis for companies that tackle and overcome risk better than others. The fact that risks exist and that things can go wrong serve as a natural barrier for over-establishment in any industry. There is seemingly something Darwinian ("survival of the fittest") about the ability to thrive and make money in any business. The ability to deal with (and over time adapt to) various risk factors is an important element for continued existence. Unprepared firms essentially gamble that they will avoid the effects of a disruptive or damaging event (Autry \& Bobbitt, 2008). Deliberate supply chain risk preparedness and management will be imperative to long term sustainability and should give the firm or supply chain competitive advantage in a perilous world.

A useful paper by Spekman and Davis groups supply chain risks into four general categories (Spekman \& Davis, 2004):

1. Risks inherent in supply chain flows (goods, information and money)

2. Risks associated with security (crimes). (Security management is an important subset of the realm of risk management) ${ }^{47}$

3. Risks associated with opportunistic behavior (trust issues)

4. Risks associated with corporate social responsibility (the "triple bottom line")

The prevailing view is now an all-risk strategy that emphasizes the firm and its employees' collective attention to both supply chain security management and supply chain risk management principles and methods (Autry \& Bobbitt, 2008; Closs \&

${ }^{47}$ Includes man-made threats such as terrorism, theft, vandalism, smuggling, piracy, riots and arson. 
McGarrell, 2004; J. J. Coyle et al., 2013; lakovou, Vlachos, \& Xanthopoulos, 2009;

Marucheck, Greis, Mena, \& Cai, 2011; Sweet, 2006; Williams, Lueg, \& LeMay, 2008) ${ }^{48,49}$.

The perception of risk is often what guides management and practitioners in

their decision making and prioritization. Perceived risk can be quite different than

statistical (objective) risk based on actual occurrences and trends. (C. S. Tang, 2006b;

Vanany, Zailani, \& Pujawan, 2009). Every decade has its highly publicized catastrophes, whether natural or man-made. Surveys of practitioners performed in the year 2012 typically list the more general supplier risk as the number one perceived risk. ${ }^{50} \mathrm{~A}$ recurring "risk-of-the-month" phenomenon illustrates our reactive nature and how our perception of reality is shaped by recent or close events. Gail Dutton remarks that "supply chain managers who focus on the most recent threat will be blind-sided by something else" (Dutton, 2013). Tversky and Kahneman wrote an important article on cognitive biases that stem from people's reliance on judgmental heuristics, especially when making judgments under uncertainty (Tversky \& Kahneman, 1974). Despite our instinctive inclination to be reactive and focus on recent events, it seems the literature on risk management has now arrived at a more balanced, "all-risk" perspective emphasizing the importance of being prepared for any eventualities. Several books on

\footnotetext{
${ }^{48}$ Williams et al. uses a definition from Closs \& McGarrell (2004): “The application of policies, procedures, and technology to protect supply chain assets (product, facilities, equipment, information and personnel) from theft, damage, or terrorism, and to prevent the introduction of unauthorized contraband, people or weapons of mass destruction into the supply chain" (Closs \& McGarrell, 2004; Williams et al., 2008) ${ }^{49}$ Autry \& Bobbitt describe a security breach as something that contaminates, damages or destroys products and/or supply chain assets.

${ }^{50}$ Avoiding suppliers that will ship bad or unsafe products or use hazardous production methods, for example.
} 
SCRM written over the past couple of years seem to reflect this more comprehensive perspective of risks (O. Khan \& Zsidisin, 2012; Kouvelis, Dong, Boyabatli, \& Li, 2012; Olson, 2012; Manmohan S. Sodhi \& Tang, 2012; Trent \& Roberts, 2010). Tang and Musa did an extensive literature review and found that the field of SCRM since 2000 has "evolved from passively reacting to vague general issues of disruptions towards more proactively managing supply chain risk from system perspectives" (O. Tang \& Musa, 2011).

\section{Stage 3: Supply Chain Risk Management}

As pointed out by Sodhi and Tang, supply chain risk management (SCRM) is a nascent field, going back only to the early 2000's (Manmohan S. Sodhi \& Tang, 2012). Several authors have carried out extensive and useful literature reviews on SCRM, and it is evident that this is an area of research and practice that is still in a relatively early stage (Ghadge, Dani, \& Kalawsky, 2011; Jüttner et al., 2003; Rao \& Goldsby, 2009; Vanany et al., 2009). Overlapping fields such as Enterprise Risk Management (ERM) and Emergency \& Disaster Preparedness have been around a bit longer, and for these there exists an older body of literature (Hale \& Moberg, 2005; Olson \& Wu, 2010). ERM embraces a broader and more general area of the risks that a company could run into, and can be defined as "... the discipline by which an organization in any industry assesses, controls, exploits, finances, and monitors risks from all sources for the purpose 
of increasing the organization's short- and long-term value to its stakeholders." (CAS, $2007)^{51}$

Organizations often discuss ERM in the context of financial and strategic risk (Handfield, 2007). Supply chain risks overlap with other risks experienced by organizations, and what is damaging to a company's supply chain will usually slop over and cause negative financial and marketing consequences. Based on a 2006 survey of financial executives that revealed that their greatest worry was supply chain risks, Harris Interactive advised that it is all too easy to look at risk in silos (Smyrlis, 2006). A 2009 survey by Sodhi et al. revealed that nearly three quarters of the respondents believed SCRM to be a subset of ERM or an extension of it (Manmohan S. Sodhi et al., 2012).

The definitions given in Table 8 reveal that we now have moved into the solution stage of organizational processes. What can managers do to the supply chain to anticipate and handle the inevitable risks? The literature seems to center around the following predicaments:

- We have this supply chain structure and we need to get this product to the customer!

- What can possibly go wrong or has gone wrong?

- How do we fix it and prevent it from happening again?

The SCRM literature is, therefore, quite prescriptive in its way of analyzing and recommending processes and solutions to the management. As Harland et al.

\footnotetext{
${ }^{51}$ A slightly different definition of ERM is offered by Wikipedia: "The methods and processes used by organizations to manage risks and seize opportunities related to the achievement of their objectives." Chapman is credited with this definition: "ERM as a set of coordinated actions about protecting and enhancing share value to satisfy the primary business objective of shareholder wealth maximization" (Yee, 2009)
} 
Table 8: DEFINITIONS OF SUPPLY CHAIN RISK MANAGEMENT (SCRM)

\begin{tabular}{|c|c|}
\hline Definition & Author \\
\hline $\begin{array}{l}\text { The identification and management of risks within the } \\
\text { supply chain, and risks external to it, through a } \\
\text { coordinated approach amongst supply chain } \\
\text { members, to reduce supply chain vulnerability }{ }^{52} \text { as a } \\
\text { whole. }\end{array}$ & (Chapman et al., 2002) p. 61 \\
\hline $\begin{array}{l}\text { The identification and management of risks within the } \\
\text { supply chain and risks external to it through a co- } \\
\text { ordinated approach amongst supply chain members } \\
\text { to reduce supply chain vulnerability as a whole. }\end{array}$ & (Christopher, 2002) p.2 \\
\hline $\begin{array}{l}\text { Aims to identify the potential sources of risk and } \\
\text { implement appropriate actions to avoid or contain } \\
\text { supply chain vulnerability. }\end{array}$ & (Jüttner et al., 2003) p. 9 \\
\hline $\begin{array}{l}\text { Effective supply risk [management] requires the } \\
\text { identification and monetization of risk events, } \\
\text { probability of occurrence, and the firm contingencies } \\
\text { for alternative sources of supply. }\end{array}$ & (Barry, 2004) p. 695 \\
\hline $\begin{array}{l}\text { A company manages risk in order to protect its assets } \\
\text { and profits, and stay in business. }\end{array}$ & (Finch, 2004) p. 194 \\
\hline $\begin{array}{l}\text { Risk management is primarily concerned with } \\
\text { removing the degree of ambiguity or uncertainty } \\
\text { concerning the task environment and the decision } \\
\text { specific variables. }\end{array}$ & (Brindley, 2004) p. 70 \\
\hline $\begin{array}{l}\text { To collaboratively with partners in a supply chain } \\
\text { apply risk management process tools to deal with } \\
\text { risks and uncertainties caused by, or impacting on, } \\
\text { logistics related activities or resources. }\end{array}$ & (Norrman \& Lindroth, 2004) p. 14 \\
\hline $\begin{array}{l}\text { Focusing on their supply chains in order to reduce } \\
\text { uncertainty and increase customer satisfaction, with } \\
\text { the ultimate aim of generating greater levels of } \\
\text { productivity, profitability and competitiveness. }\end{array}$ & (P. J. Singh et al., 2005) p. 3375 \\
\hline $\begin{array}{l}\text { The management of supply chain risks through } \\
\text { coordination or collaboration among the supply chain } \\
\text { partners so as to ensure profitability and continuity. }\end{array}$ & (C. S. Tang, 2006a) p. 453 \\
\hline $\begin{array}{l}\text { The organizational routines or regular and predictable } \\
\text { patterns of activity and sequence of coordinated ac- } \\
\text { tions that, when bundled with rent-yielding resour- } \\
\text { ces, enhance the abilities of the supply chain to reco- } \\
\text { ver expediently from a manifested disruption and to } \\
\text { create awareness of a pending or realized disruption. }\end{array}$ & (Craighead et al., 2007; Grant, 2002) \\
\hline
\end{tabular}

${ }^{52}$ Vulnerability is defined as "the degree to which people, property, resources, systems and cultural, economic, environmental and social activity is susceptible to harm, degradation, or destruction on being exposed to a hostile agent or factor" (Prakash, 2011). Also, vulnerability is a latent condition which becomes manifest if a disruptive event occurs (Jüttner \& Maklan, 2011). Not wearing a bicycle helmet is not a problem until you fall off your bike. 


\begin{tabular}{|c|c|}
\hline $\begin{array}{l}\text { The goal of risk management is to empower senior } \\
\text { decision makers with a rational basis for determining } \\
\text { which risk mitigation measures to enact versus how } \\
\text { much and where to accept other risks. }\end{array}$ & $\begin{array}{l}\text { (Ritter, Barrett, \& Wilson, 2007), p. } \\
86\end{array}$ \\
\hline $\begin{array}{l}\text { Risk management involves developing strategies for } \\
\text { reducing the probabilities of negative events and/or } \\
\text { their consequences should they occur. }\end{array}$ & (Cohen \& Kunreuther, 2007) \\
\hline $\begin{array}{l}\text { Having the objective to control, monitor and evaluate } \\
\text { supply chain risk. The core activity of SCRM is the } \\
\text { systematic identification, assessment and } \\
\text { quantification of potential supply chain disruptions. }\end{array}$ & $\begin{array}{l}\text { (McCormack et al., 2008) p. } 8 \text { and p. } \\
10\end{array}$ \\
\hline $\begin{array}{l}\text { The identification and evaluation of risks and } \\
\text { consequent losses in the global supply chain, and } \\
\text { implementation of appropriate strategies through a } \\
\text { coordinated approach among supply chain members } \\
\text { with the objective of reducing one or more of the } \\
\text { following - losses, probability, speed of event, speed } \\
\text { of losses, the time for detection of the events, } \\
\text { frequency, or exposure - for supply chain outcomes } \\
\text { that in turn lead to close matching of actual cost } \\
\text { savings and profitability with those desired. }\end{array}$ & (Manuj \& Mentzer, 2008b) p. 205 \\
\hline $\begin{array}{l}\text { Management controls create supply chain } \\
\text { capabilities, or attributes that enable an enterprise to } \\
\text { anticipate and overcome disruptions. }\end{array}$ & (Pettit, Fiksel, \& Croxton, 2010) \\
\hline $\begin{array}{l}\text { To evaluate, control and monitor risk in order to } \\
\text { safeguard supply continuity and maximize } \\
\text { profitability, and ... the process of planning, } \\
\text { organizing, leading and controlling the activities of an } \\
\text { organization in order to minimize the effects of risk } \\
\text { on an organization's capital and earnings (includes } \\
\text { financial, strategic, operational, accidental losses and } \\
\text { other risks). }\end{array}$ & (Trent \& Roberts, 2010) \\
\hline SCRM can be seen as the capacity to be agile. & $\begin{array}{l}\text { (Lavastre, Gunasekaran, \& } \\
\text { Spalanzani, 2012) p. } 830\end{array}$ \\
\hline $\begin{array}{l}\text { Supply chain solutions that ensure supply continues } \\
\text { to meet demand in case of a disruption or soon after } \\
\text { the occurrence of such a disruption. }\end{array}$ & $\begin{array}{l}\text { (Manmohan S. Sodhi \& Tang, 2012) } \\
\text { p. } 303\end{array}$ \\
\hline $\begin{array}{l}\text { Process to identify the likelihood of potential losses, } \\
\text { the impact on the business revenue, and mitigation } \\
\text { plans to reduce potential losses. }\end{array}$ & (Dow_Chemicals, 2012) \\
\hline $\begin{array}{l}\text { The practice of managing the risk of any factor or } \\
\text { event that can materially disrupt a supply chain, } \\
\text { whether within a single company or spread across } \\
\text { multiple companies. The ultimate purpose of SCRM is } \\
\text { to enable cost avoidance, customer service, and } \\
\text { market position. }\end{array}$ & (SCRLC, 2012) \\
\hline
\end{tabular}


observed, the combined, messy, intertwined effects of increasing product and service complexity, globalized outsourcing and e-business have resulted in more complex and dynamic supply networks (Harland et al., 2003). They recommend a variety of risk management tools to deal with this, including scenario planning ${ }^{53}$, expert panels, Delphi studies and statistically based forecasting methods. In addition, they stress the importance of contracting with and developing trustworthy suppliers. More importantly, they were the first to outline a step-by-step "supply network risk tool" that has become a conceptual framework for a lot of the prescriptive work in the SCRM field (we have tweaked this model, relabeled it "MIAMI", and used it as a framework later in this thesis):

1. Map supply network (structure, key measures, ownership)

2. Identify risk and its current location (type, potential loss)

3. Assess risk (likelihood of occurrence, stage in life cycle, exposure, likely triggers, likely loss)

4. Manage risk (develop risk position, develop scenarios)

5. Form collaborative supply network risk strategy

6. Implement supply network risk strategy

Arben Mullai outlines a risk analysis process that consists of nine steps: 1) System definition, 2) Analytical process, 3) Hazard identification, 4) Exposure analysis, 5) Consequence analysis, 6) Exposure evaluation, 7) Consequence evaluation, 8) Risk characterization and presentation, and 9) Sensitivity analysis (Mullai, 2004). Kessinger and McMorrow are industry practitioners who stress the importance of having a

${ }^{53}$ Also called "what if" analysis by some authors (Simchi-Levi, Snyder, \& Watson, 2002). "Whatif" scenarios are often used in stress-testing exercises (Jayashankar M. Swaminathan \& Tomlin, 2007) 
comprehensive and systematic process of prevention, preparedness, mitigation, response and recovery. They outline three crucial abilities:

1. Collect, communicate and respond

2. Assess the impact of uncertainty

3. Quantify supply chain performance and design supply strategies across uncertain business outcomes (Kessinger \& McMorrow, 2012)

As for studies pertaining to SCRM strategies and practices, one stream of research over the past decade has focused on developing mathematical models for supply chain issues, while another stream of research has tried to empirically establish relationships between supply chain practices and performance (Hendricks \& Singhal, 2012). Almost without fail, all of these papers have based their logical construct on the simplified Identify - Assess - Mitigate framework (What can go wrong, how can it impact us, and what can we do about it?) Trying to uncover definitional, process and methodology gaps in the SCRM literature, Sodhi et al. separated recent academic journal articles into four main elements of identification, assessment, mitigation, and responsiveness to operational and catastrophic risk incidents (Manmohan S. Sodhi et al., 2012). Most of the articles were of conceptual nature (framework building rather than empirical), and $45 \%$ of them covered identification, $58 \%$ assessment, $61 \%$ mitigation, and $19 \%$ responsiveness (several articles covered more than one element). While Jüttner et al. distinguish four basic constructs (supply chain risk sources, risk consequences, risk drivers and risk mitigating strategies) (Jüttner et al., 2003), we find 
the following five-step progression to be particularly meaningful, both conceptually and practically: ${ }^{54}$

1. Define (map) the company's supply chain

2. Identify relevant risks to which the company might be exposed

3. Assess these risks in terms of probability of occurrence and potential severity of impact

4. Mitigate the risks through prevention and damage control (contingency plans)

5. Monitor the risks and learn from past incidents, implying continuous improvement ${ }^{55}$

\section{c. The "MIAMI" Template}

An easy way to remember this five-step methodology could be to label it with the acronym MIAMI: Map, Identify, Assess, Mitigate and Improve!

\section{Mapping}

Mapping the supply chain is surprisingly challenging for many companies doing global sourcing and dealing with third party logistics providers (3PL's). This is a process that takes quite a bit of diligent detective work, and it can be hard to get reliable information from the first tier suppliers about their next level (second tier) of suppliers and their supply chain practices. However, going through a thorough process of defining and mapping the upstream supply network has several benefits and may reveal inefficiencies, redundancies and, of course, risks.

\footnotetext{
${ }^{54}$ Manuj and Mentzer present a similar five-step process that consists of risk identification, risk assessment \& evaluation, selection of appropriate risk management, implementation of supply chain risk management strategies, and mitigation of supply chain risks (Manuj \& Mentzer, 2008a)

55 There are some similarities here to the DMAIC (define-measure-analyze-improve-control) cycle found in the Six Sigma quality management theory. Lee and Whang wrote a paper on how to use Six Sigma to obtain higher supply chain security with lower cost (Lee \& Whang, 2005)
} 
In this early stage it also makes sense to recognize the risk drivers that the company operates under (Jüttner et al., 2003). These drivers tend to increase the risk exposure of the company. Examples are single sourcing, lean practices with low inventories and tight deadlines ${ }^{56}$, short product cycles, long transportation routes and complex products with suppliers scattered all over the world. Before worrying about what can go wrong we need to know who we are, how we operate and what our supply network looks like. As Jüttner points out, the supply chain structure and practices can be a risk factor and amplifier by themselves (Jüttner, 2005).

Mapping the flow of materials, information and money also involves describing who is doing what and how and where it is done. Producing in India involves incoming raw materials and supplies, and the analyst needs to know the layers of suppliers, the source of the raw materials, and the logistics steps that are necessary to get the merchandise in and out of the production facilities. A thorough analysis also looks at the internal production processes, and the logistical flow of the factory must be mapped out. The analyst needs to know where the product is coming from, how it is transported, how it is stored, how it is processed, and how it leaves the production facilities. Is the business power or water intensive? Does the business rely on unionized labor? Only through an intimate knowledge of the internal supply chain processes can the analyst start focusing on the identification and assessment of the risks and possible disruptions that can affect the specific supply chain. Although the risk identification and assessment

\footnotetext{
${ }^{56}$ Typical of Just-in-Time (JIT) type procurement and manufacturing practices.
} 
processes themselves serve as filters, elimination of irrelevant scenarios and simplification at the mapping stage make it easier to focus in on proper situational and circumstantial risks instead of spending time on hypothetical risks that the company will never fall victim to ${ }^{57}$. The process of mapping that we are describing here can be done in a structured fashion similar to the key steps recommended in a logistics/supply chain network design process. Such systematic processes - that often include audits to provide a comprehensive perspective on the company's logistics processes - are well described in many modern supply chain textbooks (J. J. Coyle et al., 2013). We are concerned with creating an initial system awareness (Zsidisin, Ragatz, \& Melnyk, 2004).

The Supply Chain Risk Leadership Council (SCRLC) recommends the risk management process begins with identifying internal and external environments (SCRLC, 2011). At this mapping stage, it is appropriate to give some thought to the organization's own forms, structures and processes, as these may relate to the operating environment. Because risks or risky situations often occur at the intercept of the firm's characteristics and the external environment in which it chooses to operate, the firm's own attributes or impediments may indeed contribute and add to the overall risk exposure. For example, an inability to adapt could be a sustainability problem and a risk factor on its own (Carter \& Rogers, 2008). It makes the firm more vulnerable. Deciding to source from or operate in India may consequently not be the ideal choice

57 "Never say never" is of course a valid objection to this simplification approach, as there is always a chance that the "unknown unknowns" will rear their ugly heads and surprise us. So we don't want to simplify too radically. 
for a company that suffers from various forms of inertia, unless it is able and willing to modify many of its operating practices, and thereby reduce its vulnerability.

\section{Identification}

Identifying relevant risks is perhaps the most important step. Kern et al. note that superior risk identification supports the subsequent risk assessment and this in turn leads to better risk mitigation (Kern, Moser, Hartmann, \& Moder, 2012). Several researchers have classified supply risks into operational (internal) risks ${ }^{58}$ and disruption (external) risks (Kouvelis, Chambers, \& Wang, 2006; C. S. Tang, 2006a). The operational risks can be internal to the company or internal to the extended supply chain (or network), while the disruption risks primarily consist of environmental and man-made ${ }^{59}$ hazards. Environmental risks can be remediated through "business continuity planning", while man-made attacks can be prevented with "supply chain security management". (Markmann, Gnatzy, von der Gracht, \& Darkow, 2011)..$^{60}$ Some authors use a finer filter to categorize risks. For example, Manuj \& Mentzer divide risks into eight categories: Supply, Operational, Demand, Security, Macro, Policy, Competitive, and Resource risks (Manuj \& Mentzer, 2008a). Regardless of the method used to categorize the relevant risks, the target of risk identification is to identify all potential threats and all relevant vulnerabilities within the upstream part of the supply chain (Kern et al., 2012). A

\footnotetext{
${ }^{58}$ Kleindorfer and van Wassenhove call them coordination (supply/demand matching) risks (Kleindorfer \& Van Wassenhove, 2004)

${ }^{59}$ By "man-made" we include risky behavior by women, too!

${ }^{60}$ That many of these terms are used interchangeably is exemplified by this definition of business continuity planning (BCP) by Rice and Caniato: "BCP means developing plans to be resilient - that is, to be prepared to respond to and restore operations after an unexpected, major disruption occurs" (Rice \& Caniato, 2003)
} 
necessary systems perspective forces the individual company and its management to adopt both a company perspective and a supply chain perspective, simultaneously (Paulsson, 2005). Christian Verstraete defines 'operational' risks as internal to the supply chain and which can be addressed through appropriate operational adjustments, while 'structural' risks are more environmental (exogenous) in nature and requires companies to change the way they operate. The latter type of risk requires a supply chain or network to be flexible enough to transform itself (Verstraete, 2008). What is particularly interesting about Verstraete's article is the impact various risks might have on the company's competitors or competing supply chains. Not only do managers need to worry about operational and structural risks in their own supply chains, but also in competing supply chains, as an integral part of the greater business environment and industry "system".

SupplyChainDigest's tri-annual listing of "The Top Supply Chain Disasters of All Time" (Gilmore, 2009) provides a glimpse of the severity of operational risks. Of the sixteen costly episodes listed, at least eleven of them pertain to disastrous transitions and implementations of new and ambitious operating processes, such as production or warehouse management systems. In fact, of the sixteen top-ranked disasters, none of them are external disruptions like natural or man-made disasters. Two take-aways from this exposé may be that 1) "change is risky", and 2) "the enemy is within (the supply chain)".

Monroe et al. wrote a whole article on cataloguing the various sources of risks recognized in the supply chain literature between 2003 and 2010 (Monroe, Teets, \& 
Martin, 2012). They looked for general categories of risk sources, finding that the five most mentioned were supply risk, demand risk, process risk, environmental risk and control/business controls. All-in-all they spotted 39 different sources covered in 20 journal articles, and proceeded to condense these into three general categories: demand-side risk, internal processes risk, and supply-side risks. Each of these was given sub-categories of physical, informational, financial and relational. Taking a less abstract tack, a dissertation written by Oehmen identified four specific risk scenarios when sourcing in China: 'total cost too high', 'insufficient delivery reliability', 'insufficient quality', and 'damage to reputation' (Oehmen, 2009).

Based on the structured interview technique ${ }^{61}$, Oke \& Gopalakrishnan performed a study of supply chain disruptions in the retail sector (Oke \& Gopalakrishnan, 2009). They asked many of the same questions we did in our electronic survey: the company's background, the type of risks the company and entire supply chain have been exposed to or perceived as potential risks, the impacts of those risks, and the mitigation strategies that are in place to cope with them. They were also concerned with placing the identified risks into a likelihood versus impact matrix, thus being able to separate the risks into four distinct corners or classes: low likelihood/low impact, low likelihood/high impact, high likelihood/low impact and high likelihood/high impact. As it turned out, many of the identified risks clustered in the middle as medium

${ }^{61}$ Basically asking the same questions, the same way and at the same time in the interviewing process (Shank, 2006) 
likelihood/medium impact ${ }^{62}$, while the ones found to be low likelihood and high impact were man-made disasters and natural disasters. The high likelihood but low impact risks ("irritants") were climate and delays due to the Chinese New-Year's celebration. These risks are predictable, annual occurrences that can easily be prepared for.

Correctly identifying plausible risks is a challenging process. Each supply chain has different attributes and exposures. The increased complexity of global supply chains relying on outsourcing and offshoring has added new levels of risk and interdependence that are sometimes not evident until disaster strikes, exposing hidden vulnerabilities and leading to large economic losses (Cohen \& Kunreuther, 2007; Kleindorfer \& Van Wassenhove, 2004). Producing lists of plausible risks involve internal and external sources of information, both tapping into the institutional memory bank (what colleagues and supply chain partners remember) and using a variety of published sources such as annual reports by insurance underwriters, government agencies, industry associations and consulting firms specializing in risk tracking and analysis.

With respect to sourcing and operating risks in India, there exists quite a bit of statistical and anecdotal material. Table 9 contains recent rankings by eight global organizations comparing the BRIC-M countries. ${ }^{63}$ These are all large, developing production economies that can be reasonably compared to India. Table 9 shows that India has an average composite score on par with Russia. Brazil, China and Mexico have

\footnotetext{
${ }^{62}$ Examples of these mid-range supply risks were loss of key supplier, gas prices, regulations and socioeconomic factors.

${ }^{63}$ Brazil, Russia, India, China and Mexico.
} 
Table 9: VARIOUS BUSINESS ENVIRONMENT INDICES

\begin{tabular}{|c|c|c|c|c|c|c|c|c|c|c|}
\hline Organization & Index & Year & 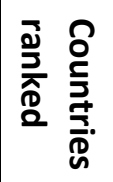 & $\frac{\bar{z}}{\frac{0}{D}}$ & $\begin{array}{l}\text { 品 } \\
\text { N. } \\
\text { N. }\end{array}$ & 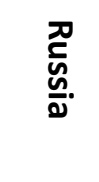 & $\frac{n}{\frac{7}{3}}$ & $\begin{array}{l}3 \\
\frac{1}{0} \\
\frac{x}{0}\end{array}$ & 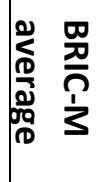 & 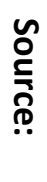 \\
\hline $\begin{array}{l}\text { Transparency } \\
\text { International }\end{array}$ & $\begin{array}{l}\text { Corruption } \\
\text { Perceptions }\end{array}$ & 2011 & 183 & 95 & 73 & 143 & 75 & 100 & 97 & $\underline{64}$ \\
\hline $\begin{array}{l}\text { International } \\
\text { Finance } \\
\text { Corporation } \\
\text { (World Bank) }\end{array}$ & $\begin{array}{l}\text { Doing } \\
\text { Business }\end{array}$ & 2012 & 183 & 132 & 126 & 120 & 91 & 53 & 104 & $\underline{65}$ \\
\hline $\begin{array}{l}\text { Heritage } \\
\text { Foundation }\end{array}$ & $\begin{array}{l}\text { Economic } \\
\text { Freedom }\end{array}$ & 2012 & 179 & 123 & 99 & 144 & 138 & 54 & 112 & $\underline{66}$ \\
\hline $\begin{array}{l}\text { World } \\
\text { Economic } \\
\text { Forum } \\
\end{array}$ & $\begin{array}{l}\text { Global } \\
\text { Competitiven } \\
\text { ess Report }\end{array}$ & 2012 & 144 & 59 & 48 & 67 & 29 & 53 & 51 & $\underline{67}$ \\
\hline $\begin{array}{l}\text { Legatum } \\
\text { Institute }\end{array}$ & $\begin{array}{l}\text { Legatum } \\
\text { Prosperity } \\
\text { Index }\end{array}$ & 2011 & 110 & 91 & 42 & 59 & 52 & 53 & 59 & $\underline{68}$ \\
\hline $\begin{array}{l}\text { United } \\
\text { Nations }\end{array}$ & $\begin{array}{l}\text { Human } \\
\text { Development } \\
\text { Index }\end{array}$ & 2011 & 187 & 134 & 84 & 66 & 101 & 57 & 88 & $\underline{69}$ \\
\hline $\begin{array}{l}\text { Global } \\
\text { Integrity }\end{array}$ & $\begin{array}{l}\text { Integrity } \\
\text { Indicators }\end{array}$ & 2011 & 100 & 70 & 76 & 71 & 64 & 68 & 70 & $\underline{70}$ \\
\hline $\begin{array}{l}\text { Property } \\
\text { Rights } \\
\text { Alliance }\end{array}$ & $\begin{array}{l}\text { International } \\
\text { Property } \\
\text { Rights Index }\end{array}$ & 2012 & 130 & 62 & 62 & 97 & 57 & 76 & 71 & $\underline{71}$ \\
\hline $\begin{array}{l}\text { Average } \\
\text { score }\end{array}$ & $\begin{array}{l}\text { The lower the } \\
\text { better }\end{array}$ & & & 95.8 & 76.3 & 95.9 & 75.9 & 64.3 & 81.6 & \\
\hline
\end{tabular}

better composite scores. India is the worst scoring country of the five in the categories

"Doing Business", "Prosperity", and "Human Development". It scores only better than

${ }^{64}$ http://cpi.transparency.org/cpi2011/results/

${ }^{65}$ http://www.doingbusiness.org/data/exploreeconomies/india

${ }^{66} \mathrm{http}: / /$ www.heritage.org/index/country/india

${ }^{67} \mathrm{http}: / /$ www3.weforum.org/docs/CSI/2012-13/GCR Rankings 2012-13.pdf

${ }^{68} \mathrm{http}: / /$ www.prosperity.com/country.aspx?id=IN

${ }^{69} \mathrm{http}: / / \mathrm{hdr}$.undp.org/en/statistics/

${ }^{70} \mathrm{http} / / /$ www.globalintegrity.org/report/India/2011

${ }^{71}$ http://www.internationalpropertyrightsindex.org/ranking 
average in the "Corruption Perceptions" and "International Property Rights" indexes.

Apparently India still has a macro and socio-economic environment that breeds many of the risks faced by companies operating there. It is still a poor country (see Table 10), with problems such as corruption, crime and insufficient infrastructure. Sourcing from this country will be made attractive only if the many potential risks are more than compensated for by cheaper production, access to resources (labor and raw materials), proximity to the markets, and an expectation that conditions will keep improving.

\section{Table 10: THE ECONOMIST'S EXPECTED GDP PER CAPITA IN 2013, SELECT ASIAN}

\section{COUNTRIES}

\begin{tabular}{|l|l|l|}
\hline Country & Population & GDP per capita \\
\hline Bangladesh & 171 million & $\$ 695$ \\
\hline China & 1.34 billion & $\$ 6,890$ \\
\hline India & $\mathbf{1 . 2 4}$ billion & $\mathbf{\$ 1 , 7 7 0}$ \\
\hline Indonesia & 251 million & $\$ 3,890$ \\
\hline Malaysia & 29 million & $\$ 11,580$ \\
\hline Pakistan & 184 million & $\$ 1,410$ \\
\hline Philippines & 106 million & $\$ 2,650$ \\
\hline Sri Lanka & 21 million & $\$ 3,150$ \\
\hline Thailand & 69 million & $\$ 5,800$ \\
\hline Vietnam & 90 million & $\$ 1,800$ \\
\hline
\end{tabular}

Source: (Economist, 2012b)

The South Asian cluster of India, Pakistan, Bangladesh and Sri Lanka has many shared socio-economic and climatic impediments. The region is prone to natural calamities such as typhoons, heavy monsoon flooding and earthquakes, and a poor and dense population causes social ills and deprives the governments the revenues they need to build infrastructure. Other problems include ethnic and religious animosities that frequently bubble up in the form of terrorist actions, riots and armed attacks. 
The Heritage Foundation in its "2012 Index of Economic Freedom" points out

that despite India's economic growth, the foundations for long-term economic

development remain fragile because of:

- An absence of an effectively functioning legal framework, where property rights are not protected effectively

- Serious corruption, especially in government procurement and defense contracts

- Government meddling in economic activity

- Restrictive and burdensome regulatory environment, where licensing takes too long and trade barriers are erected

- Inflationary pressure (Heritage_Foundation, 2012)

The World Bank and the International Finance Corporation, in their "Doing

Business 2012" report, give India very low scores in three categories, relative to 183

nations ranked (World_Bank, 2012):

- Starting a business (166 out of 183)

- Dealing with construction permits (181 out of 183)

- Enforcing contracts (182 out of 183)

India also scores worse than the average in:

- Getting electricity (98 out of 183)

- Resolving insolvency (128)

- Registering property (97)

- Paying taxes (147)

- Trading across borders (109)

Doing Business measured the time and steps needed to legally build a

warehouse in Mumbai, and found that it requires 34 procedures, takes 227 days and costs 16 times more than the average income per capita. The "Enforcing contracts" item was based on the set of procedural steps and time required to resolve a standardized commercial dispute through the courts. The main reason India placed second worst in the world on this measure was that filing such a case requires 46 procedures, an 
average of almost four years and an expense of $40 \%$ of the claim. ${ }^{72}$ Under "Trading across borders", obstacles such as excessive document requirements, burdensome customs procedures, inefficient port operations and inadequate infrastructure were listed as factors leading to extra costs and delays for exporters and importers. However, the time it takes to import or export has come down considerably over the past six years.

\section{Natural Disasters}

Appendix B contains tables, figures and maps showing frequencies and examples of the most typical natural disasters occurring in South Asia. Considering earthquakes and flooding, it turns out that India is not severely affected by the former. Almost every country in the vicinity tends to have more frequent and severe quakes than India.

Flooding is a greater concern for India. Flash floods, as well as widespread and destructive flooding from monsoonal rains (June - September) are a clear threat to people and property (Central_Intelligence_Agency, 2012). There are two types of flooding: flooding induced by excessive rainfall, and flooding as a result of rising sealevels. A 2008 analysis sponsored by the OECD predicted that India's port cities will be some of the worst affected by rising sea-levels by the year 2070. A "perfect storm" combination of population and economic growth, global sea-level rise, more intense storms and higher storm surges, and human-induced subsidence will cause severe salt

\footnotetext{
72 Another example of a slow court system was reported by Global Integrity in its "India Notebook 2011": In June of 2010, a court in Bhopal sentenced each of eight Indians to two years in jail for death by negligence in the Union Carbide gas plant leak, where thousands of people died. This verdict came down 26 years after the disaster (Global_Integrity, 2012).
} 
water flooding in coastal areas and port cities in India, including Chennai, Kolkata and Mumbai (Nicholls, 2008). Swiss Re identified India as one of the top ten countries in the world for flooding risk (Swiss-Re, 2012). Major flooding is most prevalent in the northern states of Gujarat, Rajasthan, Punjab, Haryana, Uttar Pradesh, Bihar and Assam, the eastern states of West Bengal, Orissa and Andhra Pradesh, and the southern state of Kerala (MapsOfIndia.com, 2012).

Lonely Planet writes that, generally speaking, India's climate is defined by three seasons - the hot, the wet (monsoon) and the cool (S. Singh \& Bindloss, 2007). The hot season (April - June) can bring with it periods of damaging draught, with sustained temperatures above 100 degrees $\mathrm{F}$. In the middle of the winter, temperatures can get very cold in the areas north of Delhi, and people freeze to death every year. Destructive and deadly cyclones tend to form between April and December, with peaks in May and November. An average of four to six major cyclones takes place in the North Indian Ocean every year.

India's worst natural disaster since the year 1900 in terms of casualties was an epidemic in 1920 that claimed 2 million lives. Droughts in 1942 and 1965 claimed approximately 1.5 million lives each. The natural disasters that affected the most people were droughts in May of 1987 and July of 2002, affecting more than 300 million people each event. The costliest event was a flood in July of 1993 that caused damages estimated at $\$ 7$ billion. ${ }^{73}$

\footnotetext{
${ }^{73}$ It is amazing how "inexpensive" disastrous events are in India in comparison with disasters of similar severity in the developed world. The starkest example is perhaps the 2004 tsunami, which claimed
} 
Compared to China and the United States, India cannot be characterized as

particularly disaster-prone, although its preponderance of man-made disasters seems

high (CIA, 2012; Swiss-Re, 2012):

Table 11: INDIAN DISASTERS VIS-A-VIS CHINA AND THE U.S. (\% share of world totals)

\begin{tabular}{|l|l|l|l|}
\hline Description & India \% of global & China \% of global & USA \% of global \\
\hline Natural disasters & $5.1 \%$ & $10.3 \%$ & $20.0 \%$ \\
\hline Man-made disasters & $8.7 \%$ & $6.0 \%$ & $2.0 \%$ \\
\hline Population & $17.0 \%$ & $19.2 \%$ & $4.5 \%$ \\
\hline Land area & $2.0 \%$ & $6.4 \%$ & $6.5 \%$ \\
\hline GDP, nominal & $2.6 \%$ & $10.4 \%$ & $21.4 \%$ \\
\hline Exports & $1.7 \%$ & $10.6 \%$ & $8.3 \%$ \\
\hline
\end{tabular}

In 2012, the British consultancy Maplecroft published an Asian Natural Hazards

Risk map that depicted the economic exposure of natural disasters. The map, which was compiled in cooperation with the UN, identifies Japan, China and Taiwan as having the highest economic exposure to natural hazards in absolute terms. India did not show areas of high or extreme risk on this map, except in the far north, where there is high risk of earthquakes (Maplecroft, 2012b).

\section{Man-made Disasters}

Another major source of disruptions is man-made (human induced) disasters, or "technological disasters" as EM-DAT labels them (EM-DAT, 2012). As Appendix C shows in more detail, these consist of industrial accidents such as chemical spills, structure collapses, explosions, fires, gas leaks and poisonings, in addition to a variety of

16,000 lives on the Indian east coast, but had damages assessed at only a little more than a billion dollars. The 2011 tsunami that hit Japan claimed about 20,000 lives and cost more than $\$ 210$ billion, the highest global damage estimate ever (Asian_Disaster_Reduction_Center, 2012). The reasons Indian disasters might seem financially cheap are a combination of cheap construction and low casualty insurance coverage. 
transportation accidents. Between the years 1900 and 2012, 658 such technological disasters caused the deaths of more than 32,000 people. The worst man-made disaster was the gas leak from Union Carbide's plant in Bhopal on December 3, 1984. An estimated 2,500 people perished, and 300,000 were affected. On August 11, 1979, the town of Morvi in Gujarat was flooded by a broken dam, killing 1,335 people and affecting 150,000 others. Poor quality infrastructure and high population density can be a deadly mixture. Major disasters are now being tracked closely by a variety of organizations, whether insurance underwriters or international aid agencies.

There is little evidence to support the contention that catastrophic events are becoming more frequent. The annual number of reported disasters has shown a

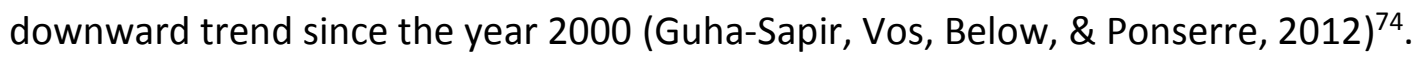
With increasing development, there is, however, a trend that the economic damage is getting higher ${ }^{75}$. L. Coleman writes, "the probability of any event impacting on people and assets has risen significantly because of the doubling of the world's population since about 1970, and a trend to locate assets - often of high value - in more hazardous areas such as coastlines" (Coleman, 2006). Wagner and Bode point out that "the vulnerability of supply chains to disturbance or disruption has increased" (S. Wagner \& C. Bode, 2006), because of a combination of factors such as more single and global sourcing.

74 Official statistics show, however, that there was a steady increase in reported disasters during the 25-year period from 1975 to 2000.

75 The three most expensive disasters (Hurricanes Katrina and Sandy, and the 2011 Japanese tsunami) have all happened within the past seven years. Note that they happened in the developed countries of the U.S. and Japan. 
Asia is the most disaster prone continent. From $2001-2010,40 \%$ of the natural disasters happened there, $90 \%$ of the victims (fatalities or affected) lived there, and $38 \%$ of the monetary damages happened there. Hydrological disasters (floods) usually have many victims, and this is a major reason for the high proportion in Asia. Flooding combined with population density ${ }^{76}$ is a dangerous combination. About half of the reported natural disasters that happened in Asia between 2001 and 2010 were hydrological (floods and mudslides).

\section{Terrorism}

Supply chains are often susceptible to property damage and interruptions caused by terrorist attacks, either directly because assets have been destroyed, or indirectly through transportation delays and security measures in the aftermaths of events. Although the timing and severity of global terrorist attacks are quite random, the locations of such attacks are mostly concentrated to a few areas. Unfortunately, India is one of those areas. Out of 158 nations, the publisher of the Global Terrorism Index - the Institute for Economics and Peace (IFEC) - ranked India as the country that was the fourth most impacted by terrorism in 2011. This was behind Iraq, Pakistan and Afghanistan (Humanity, 2013; IFEP, 2012).

So while many Middle Eastern countries are torn apart from sectarian violence and civil war, India has a somewhat different situation. IFEC writes that attacks on

\footnotetext{
${ }^{76}$ Bangladesh, India and Sri Lanka are three of the most densely populated countries in the world. According to Wikipedia, Bangladesh has a density of 1,034 people per square kilometer, India's is 368 , and Sri Lanka's is 345.
} 
Indian soil can be divided into foreign and home grown terrorism. The foreign breed has religious (Islamic vs. Hindu) overtones and is related to the conflict with Pakistan over Kashmir. The home grown one has to do with the Naxalite-Marxist insurgency in eastern India. It is notable that the Communist Party of India (Maoist) is responsible for $45 \%$ of all attacks in the country. IFEC points out that the vast majority of terrorism which occurs in India is by politically motivated nationalists and separatists. Overpopulation may be one underlying cause of these tensions. As noted by Mother Jones Magazine, "India, where the dynamics of overpopulation and overconsumption are most acute, where the lifelines between water, food, fuel, and 1.17 billion people $-17 \%$ of humanity subsisting on less than $2.5 \%$ of the globe's land - are already stretched dangerously thin" (Whitty, 2010). The size of India is less than a third of the United States, but the population is almost four times higher. From a business and supply chain standpoint, this dense population creates an abundant labor pool and promising sales opportunities, but downsides are the risk of congestion, delays and interruptions from terrorist attacks, riots or civil unrest.

Supply chain risk managers must be mindful of the potential interruptions from terrorism in India. Foreign owned or export oriented companies do not seem to be specifically targeted. Most of the attacks have been against soft targets, such as crowds of people, often in connection with public transportation. There does not seem to be a pervasive anti-western or anti-foreign sentiment in India, as the terrorism has mostly been of religious or domestic nature. 
Risk managers must stay informed about what trends may affect the countries they are operating in, such as India. For example, a recent report by the British consultancy Maplecroft warned that India's massive population and increasing demand for scarce resources make it (and Bangladesh) particularly sensitive to climate change. They recommend that "understanding climate vulnerability will help companies make their investments more resilient to unexpected change" (Guardian_The, 2010). The combination of high economic exposure and weak resilience make several Asian economies, including India, vulnerable to the fallout of large natural disasters. "These would not only include disruptions to their domestic economies, but also to the operations and supply chains of many of the world's largest corporations who invest in these locations because of their significant growth opportunities" (Maplecroft, 2012a).

\section{Risk Taxonomies and India}

Based on an in-depth review of the business related risk literature, Rao and Goldsby developed a detailed typology of supply chain risk (Rao \& Goldsby, 2009). They broke supply chain risk into five main factors, each with several sub factors as follows:

1. Environmental risk (Political, Policy, Macroeconomic and Social)

2. Industry risk (Input market, Product market and Competitive)

3. Organizational risk (Agency, Credit, Liability and Operating)

4. Problem specific risk (Risk interrelationship, Objectives and constraints, Task complexity)

5. Decision maker risk (Knowledge/Skill/Biases, Information seeking, Rules and procedures, Bounded rationality)

The typology is useful for managers in their identification and assessment of various operational risks. Companies should develop suitable typologies and 
breakdowns that fit their products and operating environments. For example, another useful listing of supply-related risks are provided by Sodhi and Lee (they also broke these risks into whether they needed strategic or operational decisions to be mitigated) (M.S. Sodhi \& Lee, 2007):

- Mergers-and-acquisitions threat (i.e. a competitor buying a major supplier)

- Acts of God and Acts of man (natural disasters, war, terrorism, sanctions)

- Political risk

- Capacity risk (too much or too little)

- Single sourcing (relying on too few suppliers)

- Intellectual property risk

- Supplier delays

- Inventory risk (obsolescence, space, cost)

In addition, they include these as "contextual" risks:

- Environmental risk and compliance

- Regulation compliance

- Exchange rates

- Financial risk

- Systems risk (information infrastructure and networks)

- Cultural differences

In comparing and ranking Chinese, Ukrainian and Brazilian suppliers, Reuven Levary chose to separate risks into four criteria: Supplier reliability, country risk, transportation company reliability, and reliability of the suppliers' suppliers (Levary, 2007) ${ }^{77}$. Mahendran et al. presented a paper in 2011 where they categorized numerous risks relevant for the Indian market. These were extracted using a case study and semi-

\footnotetext{
${ }^{77}$ Hereafter, reliability is defined as "the ability of a system or component to perform its required functions under stated conditions for a specified period of time, or even resist failure" (Schmitt \& Singh, 2012)
} 
structured interview of executives in the Indian pharmaceutical industry (Mahendran, Narasimhan, Nagarajan, \& S, 2011):

\section{A. Supply Risks:}

- Imports: Transport delays, customs delays, holiday delays, striking laborers

- Inferior quality of supply

- Non-availability of resources: raw materials, packaging materials

- Natural disasters (floods, earthquakes), Monsoon season

- Man-made disasters (terrorism, insurgencies, political rallies, protests)

- Selection of supplier

- Cost risk (increase in fuel cost, taxes, packaging materials)

\section{B. Production risks:}

- Malfunction of machinery

- Human risks (negligence, ignorance, labor unrest)

- Wrong packaging

- Power shutdown
C. Demand risks:

- Forecasting errors D. Miscellaneous risks:

- Transportation risks (delays, does not reach destination, hazardous materials )

- Quality risks

- Storage risks

- Information sharing risks

- Government safety regulations

The Boston Consulting Group's India office recently confirmed that Indian pharmaceutical companies continue to grapple with "a plethora of local challenges", for instance, poor infrastructure, paucity of skilled manpower, or the policy framework (Nandgaonkar \& Sebastian, 2012). Tang notes that outsourced manufacturing makes a supply chain more vulnerable to disruptions such as natural and man-made disasters. He suggests that the supply network design, including supplier selection, supplier order allocations and the structure of the supply contracts are important factors in reducing the overall supply management risk (C. S. Tang, 2006a). 
It is often not the damage from the disaster itself that impedes and slows down supply chain operations. If an explosion destroys train tracks or a highway, it will have a direct impact on that transportation route, but the indirect effects can be more severe, such as lengthy delays and intrusive security measures. Mishaps happening within supply chains can also have wide ranging consequences for other parts of a company's supply chain. In 2008, the Indian pharmaceutical company Ranbaxy was barred by the U.S. Food \& Drug Administration from shipping into the U.S. more than 30 different drugs made at factories in India. There had been quality lapses at Ranbaxy factories and the company lost the confidence of the main U.S. regulator. It is currently selling in the U.S. under a consent decree which requires the company to improve manufacturing procedures, ensure accurate product data, and undergo extra oversight and review by an independent third party for five years (L. A. Johnson, 2012).

In Tang and Musa's 2011 paper they separated 138 journal articles written between 1995 and 2008 into how they catalogued risk issues. Analyzing the foci of the articles, they conveniently organized them into a flow (material, financial and information) versus activity (source, make and deliver) perspective. The articles they studied contained suggested mitigation solutions (either qualitative or quantitative) for each risk issue listed (O. Tang \& Musa, 2011).

Another very comprehensive list of risk categories and their risk triggers is given by Tummala and Schoenherr in a 2011 paper. They provide a table of ten risk categories and dozens of affiliated risk triggers. For example, under what they label "sovereign risks" they include regional instability, communication difficulties, government 
regulations, loss of control, and intellectual property breaches as the risk triggers

(Tummala \& Schoenherr, 2011). Their listing is a smorgasbord for researchers and practitioners looking for suitable risk categories to use in their analyses and risk management processes.

Thun and Hoenig, as well, divided supply chain risks into external and internal risks when they surveyed German automotive executives on vulnerability. Their conclusion was that internal supply chain risks were regarded as more likely to occur and that such risks would have a greater impact on the supply chain (Thun \& Hoenig, 2011). They identified internal and external risks as follows:

- Internal: Supplier failure, Malfunction of IT system, Supplier quality problems, Transportation failure, Delivery chain disruptions, Increasing raw materials prices, Change in customer demand, Machine breakdowns, Technological change.

- External: Accident (e.g. fire), Strike, Terrorist attack, War, Increasing customs duty, Import restriction, Natural disaster, Oil crisis.

Some of these risks are overlapping or compounded. Looking at Thun \& Hoenig's dichotomy, it appears that the risk element 'transportation failure' could be either internal or external. The 2010 volcanic eruptions in Iceland caused transportation interruptions and failures, but such geophysical phenomena can hardly be regarded "internal" risks. However, if the company's truck breaks down, this would be an internal risk. Looking at the underlying cause should help us in cataloguing the risks and doing root-cause analyses. (Elkins, Handfield, Blackhurst, \& Craighead, 2005). Root cause analyses can reveal wicked problems, characterized by contradictions, ambiguities, constraints and conflicting interests, and complex enough to defy simple solutions. 
There are many challenges in managing risks within interdependent networks (Heal, Kearns, Kleindorfer, \& Kunreuther, 2006). Viewed as systems of interacting and interlocking networks, Helen Peck offers these reasons why supply chain risk is a wicked problem (Peck, 2005, 2009):

- Multiple stakeholders

- Competing interests and value sets

- No single common definitive goal

- No clarity of mission

- No universal solution

- To understand the problem you must understand the context Related to the internal vs. external risk debate is the perspective given by Trkman and McCormack. They look at endogenous risk as having its source within the supply chain and it can lead to changing relationships between the focal firm and the suppliers. Market and technology turbulence are mentioned as the most notable endogenous risks (Trkman \& McCormack, 2009). Exogenous risks originate from outside the supply chain. They divide these risks into discrete events such as terrorist attacks, epidemics and workers' strikes, and continuous risks such as inflation and price changes. They point out that mitigation of endogenous risks involve working with the suppliers, while exogenous risks cannot generally be reduced but be minimized through a level of preparedness and resilience. Most contextual, exogenous risks are beyond the control of the company or its supply chain and are less manageable than endogenous risks (Ritchie \& Brindley, 2007) ${ }^{78}$.

\footnotetext{
${ }^{78}$ Ritchie and Brindley also use the terms unavoidable or systematic for exogenous risks.
} 
Wagner and Bode prefer to classify risks into the three major sources of demand-side, supply-side and catastrophic (S. M. Wagner \& C. Bode, 2006). (Later they added two more classes: regulatory (including legal and bureaucratic) risks and infrastructure risks (Wagner \& Bode, 2008)). In several ways the risks associated with the classic business processes of "source, make and deliver" are intertwined (Yuan et al., $2012)^{79}$

From the recent literature we also considered problems such as misaligned incentives, moral hazards, adverse selection, lack of accountability, agency relationships and goal congruency, and found these issues somewhat useful in preparing our empirical survey (World_Economic_Forum, 2012a; Zsidisin \& Ellram, 2003; Zsidisin \& Smith, 2005). Many of Zsidisin's papers focus on uncovering and reducing supplier risk, suggesting proactive supply management tools to improve supplier quality and performance and preventing interruptions (Zsidisin, Ellram, et al., 2004). The supply risks he specifically identifies as relevant to in-bound supply are business (financial) risk, supplier capacity constraints, quality risk, technological change risk, product design change risk, and disasters (Zsidisin et al., 2000). Andreas Norrman points out that as agents, suppliers often have different objectives, information and risk attitudes, causing the classic pitfalls in agency theory of opportunism, self-interest and asymmetric information. He recommends well-specified contracts, including risk-sharing contracts, to prevent this and promote more cooperative, long-term and trusting exchange

79 The material flows of "source, make and deliver" are sometimes expressed as "supply, conversion and distribution" (Sheffi \& Rice, 2005). 
relationships (Norrman, 2008). Instead of just pushing risk onto the suppliers, risk and gain sharing contracts are encouraged.

The following classification of risks constitutes a preliminary framework for the survey questionnaire used in the empirical portion of this study. The risks eventually included in the survey were a distillate of these:

Table 12: CLASSIFICATION OF RISKS AND EXAMPLES RELEVANT TO INDIA

\begin{tabular}{|c|c|c|c|c|c|c|}
\hline$\sum^{0}$ & Subtype & $>$ Examples & $\begin{array}{l}\text { Internal } \\
\text { or } \\
\text { External }\end{array}$ & $\begin{array}{l}\text { Control- } \\
\text { able? }\end{array}$ & $\begin{array}{l}\text { Source, } \\
\text { make or } \\
\text { deliver }\end{array}$ & $\begin{array}{l}\text { Litera- } \\
\text { ture } \\
\text { source }\end{array}$ \\
\hline 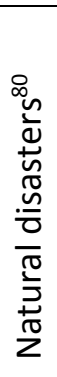 & $\begin{array}{l}\text { Geophysical } \\
\text { Meteorological } \\
\text { Hydrological } \\
\text { Climatological } \\
\text { Biological }\end{array}$ & $\begin{array}{l}>\text { Earthquake, } \\
\text { tsunami } \\
>\text { Wind storm } \\
>\text { Flood } \\
>\text { Drought, heat \& } \\
\text { cold waves } \\
>\text { Epidemics, } \\
\text { pandemics }\end{array}$ & External & No & $S, M, D$ & $\begin{array}{l}\text { (Guha- } \\
\text { Sapir et } \\
\text { al., 2012) }\end{array}$ \\
\hline 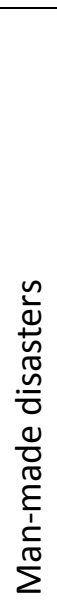 & $\begin{array}{l}\text { Transportation } \\
\text { accidents } \\
\text { Industrial } \\
\text { accidents } \\
\text { Human } \\
\text { misdeeds }\end{array}$ & $\begin{array}{l}>\text { Road } \\
>\text { Rail } \\
>\text { Air } \\
>\text { Water } \\
>\text { Fire } \\
>\text { Explosion } \\
>\text { Spills, leaks } \\
>\text { Collapses } \\
>\text { Terrorist attacks } \\
>\text { Mass murder } \\
>\text { Warfare } \\
>\text { Riots } \\
>\text { Sabotage }\end{array}$ & $\begin{array}{l}\text { Can be } \\
\text { both } \\
\text { External }\end{array}$ & Some & $\mathrm{S}, \mathrm{M}, \mathrm{D}$ & $\begin{array}{l}\text { (EM-DAT, } \\
2012 \text { ) }\end{array}$ \\
\hline
\end{tabular}

${ }^{80}$ It is easy to envision that compound, multifaceted disasters often happen. In tropical areas, a classic domino effect may be an earthquake that sets off a tsunami that causes severe flooding that triggers looting and riots and eventually starvation and a cholera epidemic. Later effects may be political and fiscal crises. In the words of the World Economic Forum, "the initial event results in a cascading disruption or failure across regions or industries" (World_Economic_Forum, 2012b). That organization separates the risks into environmental, geopolitical, economic and technological. 


\begin{tabular}{|c|c|c|c|c|c|c|}
\hline 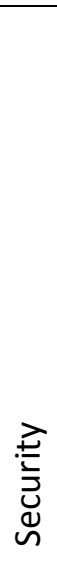 & $\begin{array}{l}\text { Violent crimes } \\
\text { Property } \\
\text { crimes } \\
\text { Financial } \\
\text { crimes } \\
\text { Product crimes }\end{array}$ & $\begin{array}{l}>\text { Murder \& assault } \\
>\text { Kidnapping } \\
>\text { Theft, robbery } \\
>\text { Cargo theft } \\
>\text { Vandalism } \\
>\text { I.P. violations } \\
>\text { Piracy } \\
>\text { Blackmail } \\
>\text { Corruption } \\
>\text { Bribery, kickbacks } \\
>\text { Contamination } \\
>\text { Counterfeiting }\end{array}$ & $\begin{array}{l}\text { Internal } \\
\text { Internal }\end{array}$ & Some & $S, M, D$ & $\begin{array}{l}\text { (Burges, } \\
\text { 2011) }\end{array}$ \\
\hline 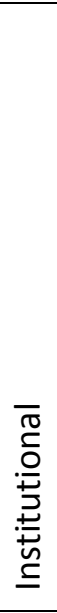 & $\begin{array}{l}\text { Governmental } \\
\text { regulations } \\
\text { Politics } \\
\text { Labor } \\
\text { regulations } \\
\text { Court system }\end{array}$ & $\begin{array}{ll} & \text { Restrictions } \\
> & \text { Licenses \& } \text { permits } \\
& \text { Red tape } \\
& 81 \\
> & \text { Tax laws } \\
> & \text { Customs delays }{ }^{82} \\
> & \text { Instability } \\
> & \text { Unpredictability } \\
> & \text { Conflicting, } \\
& \text { confusing } \\
> & \text { Restrictive } \\
> & \text { Slow } \\
> & \text { Discriminatory }\end{array}$ & $\begin{array}{l}\text { External } \\
\text { Can be } \\
\text { both } \\
\text { Can be } \\
\text { both }\end{array}$ & No & $S, M$ & Multiple \\
\hline 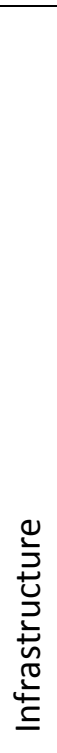 & $\begin{array}{l}\text { Transportation } \\
\text { Utilities }\end{array}$ & $\begin{aligned} & \text { Bad roads } \\
&> \text { Slow rail } \\
&> \text { Congested } \\
& \text { seaports } \\
&> \text { Congested } \\
& \text { airports } \\
&> \text { Poor public } \\
& \text { services } \text { Insufficient } \\
& \text { capacity } \\
&> \text { Unsatisfactory } \\
& \text { water supply } \\
&> \text { Unstable power } \\
& \text { supply } \\
&> \text { Internet } \\
&> \text { Telephone }\end{aligned}$ & $\begin{array}{l}\text { Can be } \\
\text { both }\end{array}$ & Some & $\mathrm{S}, \mathrm{M}, \mathrm{D}$ & $\begin{array}{l}\text { (World_E } \\
\text { conomic } \\
\text { Forum, } \\
\text { 2012a) }\end{array}$ \\
\hline
\end{tabular}

81 "A bureaucracy known for delays, dithering and lack of accountability" in the words of The Washington Post (Lakshmi, 2010)

${ }^{82}$ According to APCAC, Customs is still the primary chokepoint for supply chains (APCAC, 2011) 


\begin{tabular}{|c|c|c|c|c|c|c|}
\hline $\begin{array}{l}\bar{\pi} \\
\frac{0}{0} \\
\frac{0}{+0} \\
\frac{0}{0} \\
\frac{0}{0}\end{array}$ & $\begin{array}{l}\text { Manufacturing } \\
\text { Logistics }\end{array}$ & 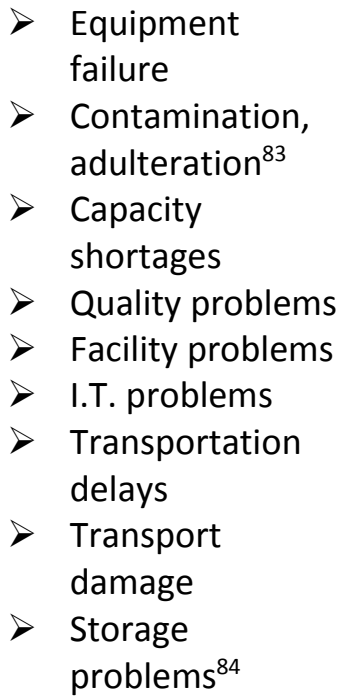 & Internal & Yes & S,M,D & Multiple \\
\hline 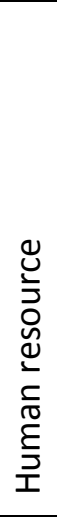 & $\begin{array}{l}\text { Education, } \\
\text { training } \\
\text { Quality } \\
\text { Cultural }\end{array}$ & $\begin{array}{l}>\text { Skills } \\
>\text { Language } \\
>\text { Productivity } \\
>\text { Poor work ethic } \\
>\text { Absenteeism } \\
>\text { High labor } \\
\text { turnover } \\
>\text { Misunder- } \\
\text { standings } \\
>\text { Miscommuni- } \\
\text { cation }\end{array}$ & Internal & Yes & $M$ & $\begin{array}{l}\text { (Kumar \& } \\
\text { Sethi, } \\
2005 \text { ) }\end{array}$ \\
\hline 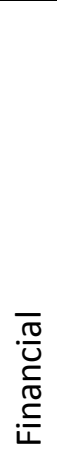 & $\begin{array}{l}\text { Macro- } \\
\text { economic }\end{array}$ & $\begin{array}{ll}> & \text { Inflation } \\
> & \text { High interest } \\
& \text { rates } \\
> & \text { Unstable } \\
& \text { exchange rates } \\
> & \text { Banking system } \\
> & \text { Bankrupt } \\
& \text { suppliers } \\
> & \text { Access to } \\
\text { financing }\end{array}$ & External & Some & $S, M$ & Multiple \\
\hline
\end{tabular}

${ }^{83}$ The 2013 European horse meat scandal is bound to become a classic SCRM story (Wise, 2013)

${ }^{84}$ The country's inefficient cold chain network results in spoilage of almost $40 \%$ of its total agricultural production (Subin, 2011), while $7 \%$ to $15 \%$ of wheat and rice stocks are lost each year largely due to poor pick up and distribution by the government run Food Corporation of India, FCI (Sen, 2012). 


\section{Assessment}

Risk assessment (estimating the likelihood of occurrence and the possible impact) aims at evaluating and understanding each risk in detail for its relevancy (Kern et al., 2012). Conventionally, the assessment phase of risk management involves comparing the probability of a given negative event to the impact such an event may have on the organization. The main purpose of such a binary comparison is to help managers identify the risks factors that may need more attention and resources to mitigate. Risks with both a high probability of occurrence and a high potential impact on the firm are obviously not desirable, and some sort of management action will be necessary to avoid serious disruptions or catastrophes. As stated by Sheffi and Blackhurst et al., the impact of disruptions on a system (i.e. an organization) varies depending on the level of resiliency within the supply chain (Blackhurst, Dunn, \& Craighead, 2011; Sheffi, 2005). Supply chain resilience is the firm's ability to recover from disruptive events (Rice \& Caniato, 2003) ${ }^{85}$. A firm's resiliency enhancers are defined as attributes that increase the ability to quickly and efficiently recover from a disruptive event (Blackhurst et al., 2011). These attributes are the resources and capabilities that the firm can muster to prevent and recover from unexpected disruptions. Jüttner and Maklan found that the four capabilities of flexibility, velocity, visibility and collaboration are the most frequently mentioned in the literature (Jüttner \& Maklan, 2011). Blackhurst et al. use systems theory to regard firms or supply chains

${ }^{85}$ Christopher and Peck define resilience as "the ability of a system to return to its original state or move to a new, more desirable state after being disturbed" (Christopher \& Peck, 2004) 
that dynamically interact with their environments, and a resource-based view to study how firms use a variety of their resources to enhance their defenses against disruptions and maintain a desirable resilience for quick recovery. Their research looked at resilience enhancers, such as the company's many resources, vis-à-vis resiliency reducers, which mostly came about as a result of the supply chain's construction and operating environment (e.g. complexity, volatilities, constraints, or regulations). According to this, the key to sustained success is to find an optimal (or at least a dynamic ${ }^{86}$ ) way to activate and mobilize the firm's resources to neutralize or reduce the detrimental elements inherent in the supply chain.

Risk assessment is the third phase of a structured risk management process. In a 2005 empirical study focusing on supply risk, Blackhurst et al. found that executives felt they needed a tool for quantitative assessment applied to the supply chain that could identify high probability "nodes" for disruptions. This would possibly give them the tools needed for disruption discovery, recovery and eventual supply chain redesign (Blackhurst et al., 2005). The executives were looking for models ("dynamic risk index tools" ${ }^{\prime \prime 7}$ ) that could provide early warning signs of potential or increasing supply risks. Through a thorough literature search, Vanany et al. found that a variety of assessment approaches were used, including brainstorming, process mapping, risk impact analysis,

${ }^{86}$ Blackhurst et al. state rather curtly that "the optimization model is no longer valid - it is a brittle model. Therefore, dynamic supply-chain models are needed." (Blackhurst, Craighead, Elkins, \& Handfield, 2005)

${ }^{87}$ Such an index could contain elements such as location, global calendar, strike negotiations, volume and capacity, weather patterns, supplier health measures, etc. 
scenario planning and a method called FMEA (failure mode and effect analysis) (Vanany et al., 2009).

Assessing probabilities becomes a process of weighing statistical likelihood against subjective, experience based "guesstimates". Unless the estimation of probability is a mathematical absolute (like rolling a fair dice, where by necessity the long term occurrence of any number is one sixth), any assignment of probability is a subjective process. The estimator's thinking is influenced by perception, mood, experience, information access and quality, traditional methodology, and recent events. Statistically we may find that India experiences an average of four or five deadly terrorist attacks every year, providing an analyst with a certain indication of probability for that type of a risk. However, unless you are a passenger on the train system or live in a northwestern state, the impact of such an attack may be minimal, especially on the typical supply chain. The difficulty is to assign probabilities to the risk factors identified, so as to gauge the possible impact. This difficulty is compounded by the fact that global sourcing often causes the firm to unwittingly be subjected to a greater risk for natural disasters, lower safety standards and less reliable legal systems, among other risks (Bosman, 2006). The more control and/or visibility the analyst has over the global supply chain, the easier it becomes to do the research and assign more realistic disruption probabilities and impact assessments. Having good information and understanding risks in quantifiable terms provide a roadmap that is crucial for risk management and continuity planning (Braun, 2012). 
While suggesting five generic risk management strategies (accept, avoid, reduce, transfer or share), Andersson and Norrman look at sourcing risks through four definitional steps: scenario, cause, effect and business impact (Andersson \& Norrman, 2004). Looking at the chain of cause and effect is useful in understanding risks and their sources, although to operationalize this it will be necessary to add some measure of probability of occurrence. According to Ellis et al., behavioral research suggests that perceptual rather than objective assessments of risk tend to guide decision-making behavior (Ellis, Henry, \& Shockley, 2010; March \& Shapira, 1987). Ellis et al. define overall supply disruption risk as an individual's perception of the total potential loss associated with the disruption of supply of a particular purchased item from a particular supplier. This appears to be a very pragmatic way of handling the risk analysis: assess each product (or at least product category) by each supplier. Various products will face different risk scenarios, as will the various suppliers, depending on their operating practices, experience, size, financial situation and geographic location. Ellis et al. define probability of supply disruption as the perceived (judged) likelihood that a supply disruption will occur and the magnitude of supply disruption as the perception of the severity of losses that may result from a disruption. The manager judging probabilities and severities is influenced by several factors, including the person's position, age, education, expertise, experience, cognitive ability, mood, the immediacy of disruption, risk preference, problem framing, and prior success (Sitkin \& Pablo, 1992).

Giunipero et al. add two more situational factors that determine and influence the company's level of investment in risk management systems: degree of product 
technology, and need for security (Giunipero \& Eltantawy, 2004). They state that the distinguishing characteristics of each purchasing situation are expected to have a differential impact on the need for risk management. The degree of product technology relates to the item characteristics, such as overall product complexity. High tech markets require more extensive risk management than low-tech markets with a slower pace of technological change. Up to this point in time India has been a source of relatively low tech products (at least merchandise, maybe not services). Under this theory an increased technological sophistication will compound the overall risk from producing there. For India, the key to capturing more technological manufacturing might be to work to reduce the other major risk factors that straddle the country. As for the need for security, Giunipero and Eltantawy point to products with high security requirements, such as high tech products, foodstuffs, pharmaceuticals and weapons systems. China has had problems with the security of its food supply chain, while India has recent, published examples of problems with pharmaceutical products (L. A. Johnson, 2012).

The severity or impact on a company can consist of anything from a short-term inconvenience to apocalyptic, "Black Swan" events that put the company under. Frequent, high probability, low impact disruptions can be dealt with through good management practices, while the scarier disruptions are the ones that have relatively low probabilities but high and devastating impacts should they happen, and made worse if the company is unprepared. Kouvelis et al. suggest that "normal business risks" can be 
dealt with by possessing robustness ${ }^{88}$, while disruption risks require resilience (Kouvelis et al., 2012). Risks pose threats to the company's bottom lines (in a triple bottom line sense), as well as brand reputation and stock value. In a 2012 report, IHS divided supplier risks into two categories, resting risks and reactive risks. They claimed that the resting risks are of the more predictable business-as-usual kind and can be analyzed: supplier bankruptcy, lack of supply due to high demand, cost risks, regulatory compliance, obsolescence, and counterfeit parts. The reactive risks cannot be predicted in advance and include unforeseen economic conditions, natural disasters like floods and earthquakes, and product recalls (IHS, 2012). Such a division between resting risks and reactive risks may make sense, although the examples IHS provided did not seem overly convincing: In India, annual floods are probably more predictable than supplier bankruptcies, for example. In the same report, IHS makes the sensible observation that it is seldom one single incident or failure that causes a catastrophe, but a confluence of events that in combination leads to significant problems. Events often have a domino effect with unpredictable and perhaps exponential consequences.

Kleindorfer and Saad highlight a few statistically based methodologies used in the industry to aid in the "SAM" process (Specifying, Assessing and Mitigating risks). (Kleindorfer \& Saad, 2005). There are many similar models offered in the literature, all stressing the importance of a systematic and quantitative approach to risk assessment

\footnotetext{
${ }^{88}$ Robust supply chain strategies 1 ) enable the company to manage supply and demand fluctuations efficiently in the typical supply chain management context, and 2) help the company sustain operations at some basic level during a disruption and restore operations soon after (Manmohan S. Sodhi \& Tang, 2012)
} 
(Knemeyer, Zinn, \& Eroglu, 2009). Some authors advocate combining the frequency data with expert judgments, scenario planning and subjective probabilities. Some infrequent but high impact disasters seem to follow a power law distribution ${ }^{89}$, while chaos theory may also be useful in dispelling notions of linearity, predictability and controllability of events (M. Mitchell, 2009). Chaotic systems are sensitive to the initial or starting conditions, so while it may be difficult to predict where a disaster will go as soon as it is unleashed, it may be useful to study what conditions might trigger such cascading events. As Knemeyer et al. point out, while a supply chain manager does not know exactly when and where a tornado will strike, he can find out information about what conditions typically lead to their occurrence, when and where they are most frequent, and their likely paths. Because a chaotic system is not totally random, awareness of the initial conditions help in confining a "chaotic" string of events to within a certain range. For example, heavy Indian monsoon rains in the month of June will inevitably lead to flooding somewhere at some near point in time. The "somewhere" portion can be pinpointed fairly accurately by using observed data from previous seasons.

The consequences of certain major disruptions could be severe. Empirical research by Hendricks and Singhal and published over several articles demonstrated how major supply chain disruptions negatively affected corporate performance (Hendricks \& Singhal, 2003, 2005a, 2005b, 2012; Hendricks, Singhal, \& Zhang, 2009).

89 Instead of a normal or poisson distribution, a power law follows an exponentially declining path (practically a straight line on a log-log plot), implying a much higher probability of an extreme event happening than if a normal bell shaped distribution was used as a guide (Watts, 2003). Occasional huge failures are more likely to happen than one might think (Banker, 2009). 
Publicly announced supply chain disruptions had an immediate negative effect on share prices (about a 7\% drop), but the long term (two years following the announcement) damage to shareholder value was much worse, with an almost $40 \%$ drop ${ }^{90}$. They also were able to show that firms that suffered from disruptions experienced a lower growth rate in revenues, more variable returns, higher total costs, and were regarded as riskier by the investors, thus requiring higher returns. Hendricks and Singhal separated what they labeled "glitches" from supply chain disruptions, where they found that even glitches caused an abnormal decrease in shareholder value of more than $10 \%$. Compared to the more dramatic external disruptions such as natural disasters, glitches were defined as arising from within the supply chain, and could be a symptom of unreliable and unresponsive supply chains. From production or shipment delays, glitches ${ }^{91}$ caused mismatches between supply and demand, and were met with punishment by the financial markets.

Pyke and Tang describe the many and substantial costs incurred in connection with a product recall, both during the recall process and in the aftermath of it (Pyke \& Tang, 2010). They cite Intel Corporation's loss of $\$ 500$ million from a 1993 recall of 5.3 million Pentium microprocessors with calculation flaws. Problems with lead paint in products sourced in China prompted toy maker Mattel to recall 967,000 toys, losing two Christmas seasons and experiencing a 50\% decline in its stock price from 2007 to 2009

\footnotetext{
90 This was adjusted compared to the market, so that an abnormal return is the difference between the return on a stock and the return on an appropriate benchmark (Hendricks \& Singhal, 2005b)

${ }^{91}$ Examples of these internal glitches were inaccurate forecasts, poor planning, parts shortages, quality problems, production problems, equipment breakdowns, capacity shortfalls, and operational constraints (Hendricks \& Singhal, 2003)
} 
(Dunn, 2011) ${ }^{92}$. After a series of problems that plagued its global operations over the last three years ${ }^{93}$, Toyota announced in December of 2012 that it was recalling 7.43 million cars worldwide (NBC, 2012). This particular recall was related to a potentially defective power window switch which could cause fires. Although this is as much a manufacturing problem as a supply chain problem, the supply chain will be suffering mightily from all the costly activities in connection with the recall processing and repairs. In addition to bad PR possibly causing loss of market share, Toyota executives had to testify in front of the U.S. Congress in 2010, a $\$ 17.35$ million fine was levied on them at the end of 2012, and the Wall Street Journal reported in 2010 that the financial impact of the recalls that year could cost Toyota more than $\$ 5$ billion ${ }^{94}$. Based on a survey of supply chain executives, the Aberdeen Group reported in 2008 that $58 \%$ of companies suffered financial losses as a result of supply chain disruptions (Sadlovska, Spinks, \& Shecterle, 2008). One company surveyed in a 2003 study by MIT's Center for Transportation and Logistics estimated a $\$ 50$ million to $\$ 100$ million cost impact for each day of disruption in its supply network (Rice \& Caniato, 2003).

The last example in Table 13 illustrates a typical compound risk, or domino effect. When the Indian partner was suspected of engaging in corruption to obtain

\footnotetext{
${ }^{92}$ It should be noted here that 2007 to 2009 was a period with generally big declines in the stock markets.

${ }^{93}$ The Economist Magazine reported that Toyota suffered through a series of major safetyrelated recalls in 2009-10. The underlying causes were lean production methods, unrealistic sales goals and overwhelmed (often single source) suppliers. The negative impacts included negative PR, slumping sales and market shares, and executives being forced to testify to the US Congress (The_Economist, 2010)

${ }^{94}$ March 9, 2010: http://online.wsj.com/article/SB10001424052748704145904575111341893725992.html
} 
licenses (an internal risk), the Supreme Court arguably over-reacted by cancelling the

licenses, thereby causing the foreign investor to lose hundreds of millions of dollars.

Foreign investors obviously don't cherish this type of uncertainty.

A classic tool in risk assessment is to use a probability versus impact matrix.

Figure 3 depicts one example that we used in a recent article on supply chain disasters

Table 13: WIDELY PUBLICIZED DISASTERS 2010 - 2012 AND THEIR IMPACT

\begin{tabular}{|c|c|c|}
\hline Disaster & Underlying cause & Impact \\
\hline \multicolumn{3}{|c|}{ 1) Internal to the supply chain: } \\
\hline $\begin{array}{l}\text { Operational: Multiple Toyota } \\
\text { auto recalls }\end{array}$ & $\begin{array}{l}\text { Pressures to increase } \\
\text { production rates and } \\
\text { market share leading to } \\
\text { rushed production. }\end{array}$ & $\begin{array}{l}\text { Customers hurt or killed; } \\
\text { several billion dollars in } \\
\text { financial losses. }\end{array}$ \\
\hline $\begin{array}{l}\text { Operational and H.R.: E-coli } \\
\text { outbreak in Germany from } \\
\text { bean sprouts from an organic } \\
\text { farm (Fox_News, 2011) }\end{array}$ & $\begin{array}{l}\text { Contaminated water or } \\
\text { seeds; ideal growing } \\
\text { condition for bacteria, } \\
\text { possibly unhygienic } \\
\text { practices. }\end{array}$ & $\begin{array}{l}\text { About } 30 \text { deaths; farm shut } \\
\text { down; Spanish farm sector } \\
\text { initially suspected lost millions } \\
\text { of Euros, Russian import } \\
\text { embargo. }\end{array}$ \\
\hline \multicolumn{3}{|c|}{ 2) External (environmental) risks: } \\
\hline $\begin{array}{l}\text { Geophysical natural disaster: } \\
\text { Hundreds of Japanese } \\
\text { factories shut down for several } \\
\text { days or weeks (Ramsey \& } \\
\text { Moffett, 2011) }\end{array}$ & $\begin{array}{l}\text { Severe earthquake and } \\
\text { tsunami off Japan's east } \\
\text { coast. }\end{array}$ & $\begin{array}{l}\text { Besides loss of } 20,000 \text { lives } \\
\text { and the most expensive } \\
\text { natural disaster ever (\$300 } \\
\text { billion), worldwide plant } \\
\text { closures due to lack of } \\
\text { Japanese parts, especially in } \\
\text { the auto sector (Guha-Sapir et } \\
\text { al., 2012; McClory, 2012) }\end{array}$ \\
\hline $\begin{array}{l}\text { Institutional: Cancellation of } \\
\text { joint venture Uninor's mobile } \\
\text { licenses by India's Supreme } \\
\text { Court. }\end{array}$ & $\begin{array}{l}\text { The Indian partner was } \\
\text { involved in corruption in } \\
\text { connection with the award } \\
\text { of the licenses (arguably an } \\
\text { internal risk, too) }\end{array}$ & $\begin{array}{l}\text { Telenor (the Norwegian } \\
\text { partner) had to write off } \$ 721 \\
\text { million on the joint venture; } \\
\text { loss of market share (Source: } \\
\text { Bloomberg.com) }\end{array}$ \\
\hline
\end{tabular}

and externalities. The disruptions or risks to be concerned about are found in the "management zone", while companies cannot operate for long in the "unsustainable" or “insignificance" zones. (Udbye, 2013). The main usefulness of this two-dimensional plotting (aka Vulnerability Map) is that risks can be easily compared. 
Vulnerability maps will vary from supply chain to supply chain, and risks may be added or subtracted as the circumstances prescribe. The results of our survey should enable us to imagine an aggregate and current vulnerability map for India, keeping in mind that such a "map" will only be an average of the interpretations of risk by the companies and managers responding to the survey.

\section{Figure 2: THE PROBABILITY (LIKELIHOOD) VS. THE IMPACT (CONSEQUENCES) OF}

\section{DISRUPTIONS}

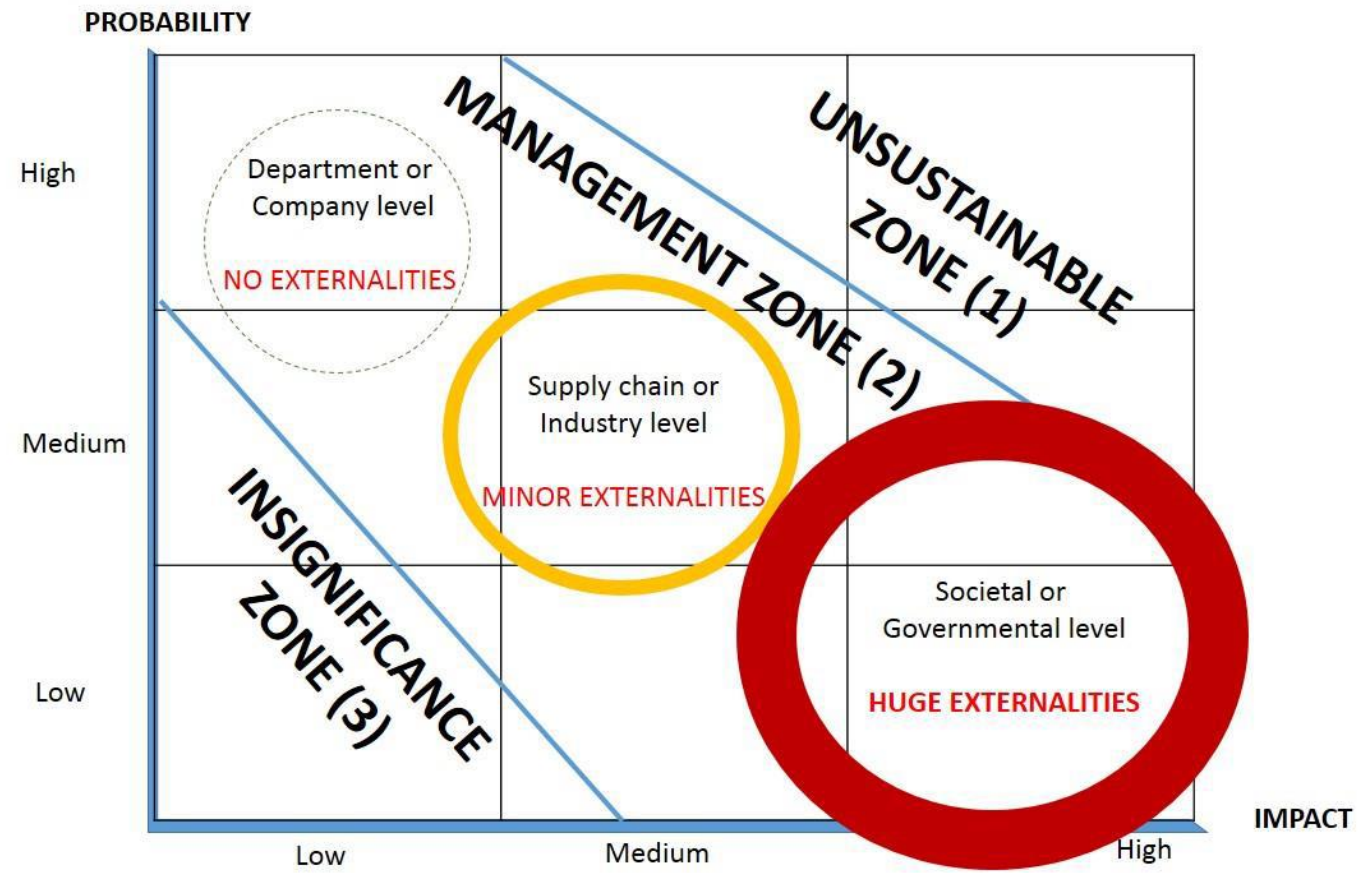

Rather than 'light' and 'severe', Tummala and Schoenherr use four levels to categorize the consequence severity: catastrophic, critical, marginal and negligible. And instead of 'low' and 'high', they use these risk probability categories: often, infrequent, rare and extremely rare (Tummala \& Schoenherr, 2011). It is problematic to find a smooth, ordinal scale when using words to describe degrees of anything. These authors, did, however, provide qualitative descriptions of their scale, so that catastrophic was 
defined as a plant closure of more than a month, critical was more than a week, marginal was decreased service levels, and negligible was no impact to service levels. 'Often' was defined as once per week, infrequent was once per month, rare was once a year, and extremely rare once every ten years. In Tummala and Schoenherr's research, the four consequence levels and four risk probability levels were assigned index scores, so that, for example, the catastrophic level would get a 4, while negligible was given a 1 . Similarly, on the probability scale an 'often' was assigned a 4, while 'extremely rare' was given a 1. By multiplying the scores for the consequence and the probability, they got what they called a "risk exposure value of risk factor", obviously with a range of 1 to 16 . By assigning estimated monetary losses to these risks, they were able to compare them to the risk control costs (again using an index) and suggest a tool for prioritizing control efforts or investments.

With respect to India, the pharmaceutical company Ranbaxy that shipped out Lipitor with glass particles was barred from selling many of its products in the U.S. This obviously caused a substantial loss of revenue in addition to legal costs. The U.S. Food and Drug Administration also sanctioned another Indian drug maker (Claris), and the U.S. giant Pfizer recalled a veterinary antibiotic from its Pune-based supplier Emcure Pharmaceuticals due to contamination (K. Singh, 2010). As India gains prominence as a manufacturer to the world, it is likely that the public will hear more about product recalls from there over the next few years. Greater investments and more modern factories should help reduce the overall incidences of product quality problems. Of the grand total of 14,076 product recalls registered with the U.S. Consumer Product Safety 
Commission between 1985 and June of 2012, as many as 2,412 were for products from China, while only 70 were for products from India 95 . On the surface this sounds promising until one realizes that 70 recalls was still the third highest in Asia (after China and Thailand), and that merchandise imports from India are still very low compared to China.

Except for negative effects on the people and businesses directly affected by the November 2008 terrorist attacks in Mumbai, the economies of Mumbai and India were not set back significantly after these attacks. Columbia University professor Arvind Panagariya wrote in Forbes Magazine in the days after the attack, "the large part of the measurable economic costs of the attacks will consist of: the cost of restoring the damaged structures of Hotel Taj, Hotel Oberoi and Nariman House; lost income earnings for those who lost their lives; expenditures on the care of those injured and suffering trauma due to lost family members; and increased expenditures on anti-terrorist measures and security precautions... A slight temporary drop in tourist activity and foreign investment may also occur" (Panagariya, 2008).

\section{Mitigation}

All the activities of mapping our supply chain, identifying relevant risks, and assessing the likelihood and impact of these risks give managers suitable information to help them figure out what to do about disruptions before and after they happen. Risk

\footnotetext{
${ }^{95}$ Source: www.saferproducts.gov
} 
mitigation covers the activities of prevention and continuity management. This section of the dissertation will focus on severe risks, including Indian risk factors and how to prepare for and avoid the various supply chain disruptions encountered there. In general, companies or supply chains can take steps to eliminate risks, reduce risks, transfer risks, or decide to assume the risks (Aliahmadi, Jafari, \& Amiri, 2006). There is a fifth option, and that is to defer the risk - or at least the impact of the risk - to enable further analysis and processing. "Kicking the can down the road" may be a justified approach if it enables better decision making. A deferment ${ }^{96}$ strategy may work well to avoid rash and expensive decisions, provided there is enough time.

In order to be effective, risk management strategies require participation of all supply chain partners (Bakshi \& Kleindorfer, 2009). Cooperation ${ }^{97}$ within the supply chain is crucial for a coordinated approach to all the upstream and downstream processes, including the physical, information and monetary flows. Sourcing represents a particular challenge in this respect, where inherent disparities and competing interests within the supply chain often result in disappointment. The interest of one supply chain participant may not be $100 \%$ aligned with the other participants, and this divergence leads to friction. ${ }^{98}$ Choosing suppliers solely on price may generate short term improvements in profitability, but will often backfire in the form of inferior quality. This

\footnotetext{
${ }^{96}$ We deliberately use the word deferment here, as a possibly better word, postponement, has a different and very specific meaning in supply chain management (i.e. delaying the completion of a product to enable flexibility)

${ }^{97}$ Bakshi and Kleindorfer made a case for "co-opetition" in their 2009 paper.

98 This particular wording was adopted from an article about Facebook in the New York Times,
} 12-19-2012. 
can be regarded a risky strategy in itself (Ritchie \& Brindley, 2007). Building on earlier articles, Christopher et al. write that any sequences of activities and the control mechanisms that support them are potential sources of risk, and they label these "process and control" risks (Christopher et al., 2011; Christopher \& Peck, 2004; Manuj \& Mentzer, 2008a). Mismatched, hapless or inappropriate management strategies and practices would fit under this category, as would more structural problems such as lack of visibility, lack of risk management strategies, dependencies and mistrust.

Zsidisin et al. suggest four major activities for ensuring supply continuity: 1) Creating system awareness, 2) Preventing supply discontinuity, 3) Remediating supply interruptions, and 4) Managing knowledge (Zsidisin, Ragatz, et al., 2004). Many authors are discussing the merits of creating a resilient supply chain, or one that can withstand disruptions, learn from them, and bounce back even stronger (Ball, 2012; Blackhurst et al., 2011; Christopher \& Peck, 2004; Ponomarov \& Holcomb, 2009; Sheffi, 2005; Zsidisin \& Ritchie, 2008) The Aberdeen Group defines four foundational pillars for a resilient supply chain: 1) visibility, 2) planning and measurement (e.g. having contingency plans), 3) sourcing and supplier management (e.g. having multiple suppliers in multiple locations), and 4) timely execution (Ball, 2012). Resilience is something the supply chain exhibits after an event or disruption has taken place. It can be enhanced by having redundancies, flexibilities and agility. Prior to a possible event, it is important to have processes in place that reduce the likelihood of being victimized by a disruption (Sheffi \& Rice, 2005). A workable definition of supply chain visibility it provided by Barratt and Oke: "the extent to which actors within a supply chain have access to or share 
information which they consider as key or useful to their operations and which they consider will be of mutual benefit" (Barratt \& Oke, 2007). Having good visibility up and down the supply chain means that the uncertainties and risks are lowered. The company will save money by allowing lower buffer inventories, ordering more accurate quantities, using more economical transportation methods, etc. A recent Ph.D. dissertation by Hung Vu Nguyen used empirical survey results to conclude that visibility is the critical relationship-specific capability that needs to develop for buying firms to mitigate supplier risk proactively (Nguyen, 2011). Visibility is enhanced by promoting and ensuring collaborative behavior within the company and within the extended supply chain. Such collaboration and communication help break down functional silos and can be, for example, between the internal departments of logistics and marketing, or externally between important suppliers and the procurement department (Ellinger, Keller, \& Hansen, 2006). Visibility is primarily accomplished through information sharing, and Lee et al. found that both inventory reduction and cost reduction are achieved through this (Lee, So, \& Tang, 2000). Moberg et al. expand on this and claim that the sharing of information and the coordination of activities among firms in supply chains can both reduce total logistics costs and enhance value delivered to the customer, leading to sustainable competitive advantage for the firm (Moberg, Cutler, Gross, \& Speh, 2002). Bode et al. use the word "bridging" for these relationship building activities, while "buffering" is the term they use for building slack resources such as safety inventories, redundant suppliers and flexible production processes (Bode, Wagner, Petersen, \& Ellram, 2011). Bridging is quite dependent on close relationships 
and trust, so to be on the safe side, companies often engage in buffering activities as additional assurance.

Another term often seen around the concepts of collaboration and coordination is "integration". According to Frankel et al., the "phenomenon of integration may be considered supply chain management's focal concept of interest" (Frankel et al., $2008)^{99}$. In a 2006 empirical survey, Germain and lyer found that to achieve better supply chain performance through external integration, a company should start with internal (inter-departmental) integration first (Germain \& Iyer, 2006). They concluded their research by stating that "the key for managers is to understand that integration should be undertaken both internally and downstream". We assume that similar benefits will be derived from upstream integration, i.e. towards the company's suppliers and logistics providers. As summarized by Richey et al., barriers to successful integration efforts include lack of trust, failure to understand the importance of supply chain integration, fear associated with losing control, misaligned goals and objectives, poor infrastructure systems, short-term as opposed to long-term focus, and supply chain complexity issues (Richey Jr., Roath, Whipple, \& Fawcett, 2010). For a variety of reasons, it is likely that most of these challenges will be present in the process of establishing successful supplier relationships in India.

99 They used a definition of integration provided in Webster's 1966 edition: "the unified control of a number of successive or similar economic or especially industrial processed formerly carried on independently". 
Two other ubiquitous terms in modern supply chain management are flexibility and agility. Rice and Caniato stress that an important distinction between flexibility and redundancy is that redundancy adds capacity, while flexibility entails redeploying previously committed capacity (Rice \& Caniato, 2003). Swafford et al. define supply chain agility as the supply chain's capability to adapt or respond in a speedy manner to a changing marketplace environment (Swafford, Ghosh, \& Murthy, 2006). They regard flexibility as being an antecedent of agility, where agility is seen as an externally focused capability and flexibility as an internally generated competency.

Swafford et al. describe adaptability as the ability to change from one state to another state in a timely and cost effective manner. Organizations or supply chains can be looked upon as "agents" in complex systems, but to survive in dynamic environments the capabilities and decision rules of the agents have to evolve over time. Learning from experience is part of this adaptation process (Bowser \& Balasubramaniam, 2009; Sterman, 2004). Lee writes about the "Triple-A Supply Chain", where he advocates agility, adaptability and alignment as all being integral to sustained competitive advantage. Alignment deals with information exchange, collaboration and the division of labor among the customers, suppliers and service providers in the supply chain network (Lee, 2004). Tang and Tomlin are concerned with "how much flexibility do we need?" They use calculus to find that to reduce supply chain risks, only a certain degree of flexibility is all it takes. Looking at various flexibility strategies, they show analytically that there is no need to go overboard with too much flexibility and too many suppliers (C. Tang \& Tomlin, 2008). 
The 2011 paper by Christopher et al. ("Approaches to managing global sourcing risk") was based on fifteen case studies (in-depth semi-structured interviews) with UK based companies, and provides four excellent high-level (generic) strategies for dealing with typical sourcing risks in several industry sectors (Christopher et al., 2011): network re-engineering, collaboration, agility, and a risk management culture.

Craighead et al. found that the severity of supply chain disruptions appears to be positively related to the supply chain density, where density is a measure of the geographic proximity of entities within a supply chain (Craighead et al., 2007). When something happens to clusters of suppliers, there is potential for more severe disruptions. The remedy for this would be to disperse the suppliers geographically. It would also make sense to broaden the concept of density to include non-geographic variables such as concentration of ownership and even foreign exchange rates. Onesidedness may provide simplicity and certain economies of scale in the short run, but can be risky if something serious disrupts the clusters. This goes for suppliers located in one area, transportation modes owned by the same company or goods purchased in the same currency.

In the same article, Craighead et al. found that complexity and the severity of supply chain disruptions also appear to be positively related. This has to do with interdependencies among the nodes and flows of the supply chain, and how disruptions tend to spread within the network when these nodes are tightly connected. While simplifying the supply network may be a good mitigation strategy, the supply chain manager ought to be mindful of too much simplification, like ending up with only one 
supplier and one transportation provider. An optimal level of supply chain complexity would appear be found in the "sweet spot" between rigidity and "chaos"100. A third problem highlighted in Craighead et al.'s article pertains to node criticality. If certain nodes (e.g. suppliers or major distribution centers) are highly critical in the supply chain, then disruptions to these would naturally have a major negative impact. A critical path analysis will help in identifying such critical nodes, and should enable management to take actions to reduce risky dependencies. Interventions such as substitute sources and rerouting are typical tools to recover capability after disruptions (Craighead et al., 2007). To be effective in the recovery efforts, communication and cooperation with the suppliers and logistics providers are also needed. To this we must add the importance of good internal communication and collaboration, which is especially critical in multinational companies.

In June of 2012, Dow Chemicals presented a paper at a CSCMP conference in Mumbai, where they listed the following examples of mitigation actions they are applying in markets like India (Dow_Chemicals, 2012)

- Change specifications to industry standard

- Qualify new suppliers

- If single sourced, qualify that supplier's products which are produced in other geographies or plants for backup

- Concentrate business with suppliers who view Dow as "core"

- Place more spend under contract

- Utilize suppliers in "safe" zones (away from hurricanes, earthquakes, etc.)

- Only do business with suppliers who have net worth over $\$ 10$ million

${ }^{100}$ We are dealing here with a version of what George Klir calls the reconstruction problem and the basic simplification principle: "a sound simplification of a system should minimize the loss of relevant information with respect to the required reduction of its complexity. ...the loss of information is measured here by the increase in uncertainty" (Klir, 2001), p.465. 
- Do business with suppliers who have short lead times

- Pick suppliers where Dow is small \% of total capacity

In a 2005 article, Elkins et al. listed eighteen "best practices" for SCRM, based on the authors' own experience and interviews with supply chain executives. The eighteen practices were tied to four key functions; 1) Strategic sourcing and advanced procurement; 2) Supply-base management; 3) Real-time operations management; and 4) Enterprise risk management/strategic supply chain design. One important finding from this project was that adopting SCRM practices can yield continuous improvement of supply chain operations and help staff members gain a better understanding of the supply chain structure and interdependencies (Elkins et al., 2005). The process itself is useful in getting to know your supply chain. The act of qualifying suppliers is part of the important process of supplier development, which includes efforts undertaken by the firm to enhance the supplier's product quality, reliability and financial performance. Such efforts include technical assistance, direct investments into supplier operations, paying visits to supplier plants, and training their personnel (Matook, Lasch, \& Tamaschke, 2009).

In the process of transforming a company to be able to see the big picture and think long term, Peter Senge's famous disciplines to create a true "learning organization" may be valuable. In a process of training the supply chain organization to be better informed and grasp a more global picture, the five disciplines of personal mastery, mental models, building shared vision, team learning and adopting a systems perspective can be productive as a starting point for instigating congruence and 
developing end-to-end visibility within the supply chain organization (Senge, 2006).

Based on a Marsh Insurance Co. survey, Enslow calls for company-wide strategic risk management, which entails process consistency, cross-functional teams and assessment procedures (including analytics and risk metrics) for plants, warehouses, stores, suppliers, second-tier suppliers, and logistics and transportation providers (Enslow, 2008). Michael Hammer extends this internal process to encourage the coordination and streamlining of intercompany processes for both cost reduction and risk mitigation (Hammer, 2001). In 2012 the Aberdeen Group wrote the following conclusion after surveying 128 companies about their supply chain visibility status: "It is important that a standardized and structured system roadmap is developed to integrate these system events and data flows as companies bring on line new capabilities and new event tracking" (Heaney, 2012). They find that companies now look further upstream into their supply chains to address visibility "blind spots", and that companies also seem to be moving towards centralized supply chain management organizations and moving to visibility under centralized control. The Aberdeen Group makes the interesting statement that "companies with shared, centralized, and more fully integrated information systems tend to be more successful in their connectivity and visibility improvement initiatives". Based on research comparing supply chain resilience to vulnerability and SCRM, Jüttner and Maklan suggested that centralized supply chain planning with decentralized local capacity could be one of the overarching principles for achieving the necessary flexibility, visibility, velocity and collaboration (Jüttner \& Maklan, 2011). In practical terms this means that a company with operations in India 
would institute a company-wide SCRM strategy, but still leave several operational problem solving decisions to the managers on the ground. Kinder recommends making every employee a risk manager by empowering them to proactively manage risk (Kinder, 2008).

Adding credence to this, the Boston Consulting Group's India office writes that "deploying risk management more broadly requires simple, foolproof, and easy-to-use systems that make risk transparent to people at the frontline, provides them a toolkit for risk mitigation and defines escalation thresholds" (Nandgaonkar \& Sebastian, 2012). A counterpoint to this view is provided by Swaminathan and Tomlin, who write "if you allow the risk attitudes and planning horizons of individual managers to determine resiliency, you cannot expect to have a consistent and coherent policy across your organization" (Jayashankar M. Swaminathan \& Tomlin, 2007). To ensure consistency they recommend standardized risk-assessment and risk management procedures across the organization. With respect to Indian operations, it may be beneficial to rely on a mixture of expatriates and local management in a crisis situation. Being somewhat ambivalent to Indian management skills, Kumar and Sethi write that "in circumstances where bold and aggressive action needs to be undertaken fast, with full backing of the [foreign] head office, expatriates can provide that extra edge" (Kumar \& Sethi, 2005). We believe that the nationalities of the management employees are less important than providing proper training and internal communication. If branch operations are left to their own devices, it is hard to know what might happen in a crisis situation. Corporate 
procedures and good training and preparation should make any disaster response more predictable, thereby reducing the overall risk ${ }^{101}$ for the corporation.

Lavastre et al. identified and ranked 21 risk mitigation methods used by French managers to "effectively and efficiently" minimize risk (Lavastre et al., 2012). The top five were:

1. Communication and information exchange

2. Accompanying providers/suppliers in improving their performance

3. Forecast accuracy

4. Long term continuity in relations with partners

5. Safety stocks (e.g. vendor-owned inventory or in-house)

The top four methods were based on close collaboration and the availability of solid information. The old "standby", safety stocks, was only number five on this list. The AMR study contained in Table 14 below does not even list safety stocks among its top ten mitigation methods. Again, closer collaboration was ranked number one.

There should be a match or at least a compromise between strategies to alleviate supply uncertainties and adjust to demand uncertainties. The ideal scenario is alignment between the interests of the customers and the upstream risk mitigation methods. Lee writes about such matched strategies (Lee, 2002). Supply chain managers also need to tailor the mitigation methods to the prevailing competitive landscape on the supply side. For example, there are definite risks in outsourcing that creates unilateral dependencies or exposure to supplier opportunism or complacency (Lonsdale, 1999). It takes two to tango, and collaboration must be based on mutual trust and

${ }^{101}$ In this case, the risk of an inappropriate or wrong response to a disruption. 
shared objectives. Based on interviews with supply chain executives, Manuj and Mentzer suggest several appropriate strategies (e.g. postponement, speculation, hedging, control/share/transfer, security and avoidance) depending on the supply and demand side uncertainty levels. They adopt a systems perspective by including team composition, supply chain complexity and inter-organizational learning into this formula, thus being mindful of the dynamics between the actors, the proper actions and the salient supply chain conditions (Manuj \& Mentzer, 2008b). In addition, business conditions change, supply chains evolve, and new risks emerge over time (Melnyk et al., 2005). Even though risk management protocols can handle localized disruptions, some high-profile events have such cascading and unintended consequences that they plainly cannot be mitigated by just one organization alone, as pointed out by the Supply Chain Risk Leadership Council (SCRLC, 2013). Adding to this, the World Economic Forum writes that "systemic risks are created or magnified by the way supply chain systems are configured", making then not easily solved by individual actors (Bhatia, Lane, \& Wain, 2013).

The expenses of protecting against a possible event can exceed the expected negative impact of the disruption. It is worth spending to protect human lives, but when it comes to potential economic losses from supply chain activities, restraint is often in order. As Norrman and Jansson point out, "to safeguard logistics processes too much could be both counteractive to current practice in logistics as well as too costly" (Norrman \& Jansson, 2004). The cost of prevention may exceed the cost of interruption. Measures such as inventory buffers, longer lead times, extra suppliers and physical 
safeguards often run counter to the prevailing necessity of leaner and more agile supply chains. Modern data harvesting and processing make collaboration, visibility and flexibility more achievable and popular, partially replacing the need for high levels of inventory and many suppliers. Inventory was the primary buffer against uncertainty for decades. Pettit et al. warn against a potential state of "unbalanced resilience", where low vulnerabilities are fought with high capabilities, subsequently eroding the firm's profitability (Pettit et al., 2010). However, to assure supply chain security, such as protection against criminal actions, there is a definite trade-off between up-front security costs versus the potentially catastrophic costs represented by a significant discontinuous event (Ritter et al., 2007). In global trade, there is no avoiding the extra expenses of physical security and compliance, although determining the "optimal" level of investment and supply chain interruption ${ }^{102}$ is always up for discussion, political debate and budgetary constraints. In other words, some disruptions should be prevented through regulation while others we just have to take and pay for (Shavell, 1984). In a world where we know that supply chain disruptions are not a question of if, but when, the issue is always how much time, money and effort should be allocated to prevention versus response (Robinson, 2012).

Using buffers such as inventory and lead time are obvious and uncomplicated measures to assure fulfillment. For that reason, the customers and sales force usually love inventories. In 2012 Schmitt and Singh published a paper wherein they used a

102 Interruption in terms of compliance requirements, delays for inspections and scanning, reporting, etc. 
discrete simulation program (Arena) to show the benefits of quick responses and buffer inventories. Indeed, they showed it was better to have the ability to quickly mobilize small buffer quantities than waiting longer for larger quantities. This implies being flexible and keeping moderate inventory buffers throughout the supply chain (Schmitt \& Singh, 2012). The "Theory of Constraints" supports this view of strategically placed buffers (Goldratt, 1992). In support of keeping some inventory throughout the system, Schmitt and Singh stated that "while minimizing inventory is an important and moneysaving endeavor, it should not be undertaken without consideration that it has a direct bearing on increasing both demand side risk and supply chain risk". Both Tomlin and Sodhi \& Tang have published articles applying mathematics and statistics to model and show how both theoretical risks and inventory levels can be reduced with independence and randomness of key variables (Manmohan S. Sodhi \& Tang, 2009; Tomlin, 2006). Regardless, as the granddaddy of risk mitigation tools, inventory will continue to have a place in the toolbox.

Table 14 presents an interesting comparison to some of the results our own research will uncover with respect to the most prevalent Indian supply chain disruptions. The four surveys in the table are not focused on India. 


\section{Table 14: HOW RECENT SURVEYS RANKED SOURCES OF DISRUPTION}

\begin{tabular}{|c|c|c|c|}
\hline Survey & $\begin{array}{l}\text { Source and } \\
\text { notable finding }\end{array}$ & Top ranked disruptions & $\begin{array}{l}\text { Consequences of } \\
\text { disruptions }\end{array}$ \\
\hline $\begin{array}{l}\text { "Supply Chain } \\
\text { Resilience } \\
2012 \text { " by The } \\
\text { Business } \\
\text { Continuity } \\
\text { Institute. } \\
\text { International } \\
\text { survey of } \\
\text { more than } \\
530 \\
\text { organizations } \\
\text { from over } 65 \\
\text { countries. }\end{array}$ & $\begin{array}{l}\text { (Glendon, 2012) } \\
73 \% \\
\text { experienced at } \\
\text { least one } \\
\text { disruptive } \\
\text { supply chain } \\
\text { incident }^{103} \text { in the } \\
\text { past } 12 \text { months, } \\
\text { with an average } \\
\text { level of five } \\
\text { incidents. }\end{array}$ & $\begin{array}{l}\text { 1. Unplanned IT or telecom } \\
\text { outages } \\
\text { 2. Adverse weather } \\
\text { 3. Outsourcer service } \\
\text { provision failure } \\
\text { 4. Earthquake/tsunami }{ }^{104} \\
\text { 5. Currency exchange rate } \\
\text { volatility }{ }^{105} \\
\text { 6. Energy scarcity } \\
\text { 7. New laws or regulations } \\
\text { 8. Fire } \\
\text { 9. Insolvency in the supply } \\
\text { chain } \\
\text { 10. Loss of talent/skills }\end{array}$ & $\begin{array}{l}\text { Loss of productivity; } \\
\text { Increased cost of } \\
\text { working; Service } \\
\text { outcome impaired; Loss } \\
\text { of revenue; Customer } \\
\text { complaints received; } \\
\text { Product release delay; } \\
\text { Delayed cash flows; } \\
\text { Damage to brand } \\
\text { reputation \& image; } \\
\text { Stakeholder \& } \\
\text { shareholder concern; } \\
\text { Expected increase in } \\
\text { regulatory scrutiny; } \\
\text { Product recall or } \\
\text { withdrawal; Payment of } \\
\text { service credits; Fined } \\
\text { for non-compliance; } \\
\text { Share price fall }\end{array}$ \\
\hline $\begin{array}{l}\text { Mckinsey } \\
\text { quarterly } \\
\text { (2006) global } \\
\text { survey of } \\
\text { business } \\
\text { executives }\end{array}$ & $\begin{array}{l}\text { (Enyinda et al., } \\
\text { 2008; } \\
\text { Muthukrishnan } \\
\text { \& Shulman, } \\
\text { 2006) } \\
\text { Two out of three } \\
\text { executives said } \\
\text { they face } \\
\text { increasing risks } \\
\text { to their ability to } \\
\text { supply their } \\
\text { customers with } \\
\text { goods and } \\
\text { services } \\
\text { effectively. }\end{array}$ & $\begin{array}{l}\text { 1. Availability of quality } \\
\text { labor } \\
\text { 2. Regulatory concerns } \\
\text { 3. Reliability of suppliers } \\
\text { 4. Commodity shortages or } \\
\text { price fluctuations } \\
\text { 5. Fluctuations in foreign } \\
\text { exchange rates } \\
\text { 6. Intellectual property } \\
\text { theft } \\
\text { 7. Obsolescence of product } \\
\text { inventory or technology } \\
\text { 8. War, terrorism, other } \\
\text { geo-political concerns } \\
\text { 9. Problems with supply } \\
\text { chain infrastructure }\end{array}$ & $\begin{array}{l}\text { Inability to supply } \\
\text { customers. }\end{array}$ \\
\hline
\end{tabular}

103 In this dissertation, "incident" is synonymous with "disruption", as well as "event". Some authors also use the word "glitch" (Hendricks \& Singhal, 2003, 2005a), although this is usually used for an operational (internal) disruption.

104 This is unusually high because of the wide impact of the Japanese earthquake and tsunami in March of 2011.

105 The fact that this financial problem pops up in a supply chain survey illustrates the interconnected nature of risks and how difficult (and futile?) it is to put risks in functional silos. 


\begin{tabular}{|c|c|c|c|}
\hline & & $\begin{array}{l}\text { 10. Plant breakdowns or } \\
\text { mechanical failures } \\
\text { 11. Natural disasters }\end{array}$ & \\
\hline $\begin{array}{l}\text { Marsh and } \\
\text { Risk } \\
\text { Insurance } \\
\text { Magazine } \\
\text { survey of } 110 \\
\text { North } \\
\text { American } \\
\text { supply chain } \\
\text { risk managers }\end{array}$ & $\begin{array}{l}\text { (Enslow, 2008) } \\
\text { Risks perceived } \\
\text { as having grown } \\
\text { more significant, } \\
\text { complex and } \\
\text { costly since } \\
2005 \text {, and many } \\
\text { firms feel } \\
\text { unprepared to } \\
\text { deal with the } \\
\text { elevated } \\
\text { exposures. Only } \\
\text { 18\% of firms had } \\
\text { consistent, } \\
\text { company-wide } \\
\text { processes for } \\
\text { SCRM. }\end{array}$ & $\begin{array}{l}\text { 1. Pricing risks (55\%) } \\
\text { 2. Risks and delays with } \\
\text { suppliers ( } 50 \%) \\
\text { 3. Risks with own plants, } \\
\text { warehouses, stores (41\%) } \\
\text { 4. Logistics delays and } \\
\text { disruptions ( } 40 \%) \\
\text { 5. Natural disasters (40\%) } \\
\text { 6. Customer-facing risks } \\
\text { (e.g. demand volatility) } \\
\text { (36\%) } \\
\text { 7. Brand reputation risk } \\
\text { (product recalls, fair } \\
\text { labor) (29\%) } \\
\text { 8. IP theft, counterfeiting, } \\
\text { gray market (26\%) }\end{array}$ & $\begin{array}{l}\text { Fragmentation of risk } \\
\text { management } \\
\text { responsibilities within } \\
\text { the firm, poor } \\
\text { coordination and knee- } \\
\text { jerk reactions. }\end{array}$ \\
\hline $\begin{array}{l}\text { AMR study } \\
\text { looking at } \\
\text { real impact of } \\
\text { risks, with a } \\
\text { global sample } \\
\text { of } 503 \\
\text { respondents. }\end{array}$ & $\begin{array}{l}\text { (Kelly, 2011) } \\
45 \% \text { of firms } \\
\text { experienced a SC } \\
\text { disruption that } \\
\text { impacted ability } \\
\text { to meet demand } \\
\text { in the past } 12 \\
\text { months. }\end{array}$ & $\begin{array}{l}\text { 1. Supply failure (41\%) } \\
\text { 2. Product quality failures } \\
\text { ( } 29 \%\end{array}$ & $\begin{array}{l}\text { Most successful } \\
\text { mitigation methods: } \\
\text { 1. Closer } \\
\text { collaboration } \\
(17 \%) \\
\text { 2. Multi sourcing } \\
(12 \%) \\
\text { 3. Vertical } \\
\text { integration of SC } \\
\text { (12\%) } \\
\text { 4. Outsourcing (10\%) } \\
\text { 5. Near-shoring } \\
\text { (10\%) } \\
\text { 6. Performance- } \\
\text { based contracts } \\
\text { (9\%) } \\
\text { 7. Business } \\
\text { continuity } \\
\text { planning (8\%) } \\
\text { 8. Increased IT \& } \\
\text { visibility (7\%) } \\
\text { 9. Commodity } \\
\text { hedges (6\%) } \\
\text { 10. Using modeling } \\
\text { tools (6\%) } \\
\text { 11. Third party } \\
\text { intelligence (4\%) }\end{array}$ \\
\hline
\end{tabular}




\section{Improving}

The last step in the "MIAMI" progression (Map-Identify-Assess-MitigateImprove) is crucial to allow the company and extended supply chain to learn from their experiences and adapt their operating procedures to the changing environments. It is not necessary to view this as a linear or chronological process, as learning, improvement and adaptation should be permeating the whole risk management area. As Closs and McGarrell put it, "supply chain security is a journey, not a destination" (Closs \& McGarrell, 2004). While Lean Six Sigma has its DMAIC ${ }^{106}$ wheel, our MIAMI wheel's improvement step has similarities to the Six Sigma Improve and Control steps in that it deals with improving the operational metrics and procedures, including optimization and sensitivity analyses where practical (Martin, 2007).

Supply chain risk management often entails "learning the hard way. A painful and expensive ( $\$ 400$ million) experience with a supply chain accident made Swedish telecommunications giant Ericsson realize the importance of proactive SCRM and taking prompt and localized action when incidents are experienced (Norrman \& Jansson, 2004).

After interviewing 20 companies, Rice and Caniato found that the survey respondents with the most progressive security and resilience initiatives had already suffered meaningful losses from previous disruptions. Subsequently these companies

${ }^{106}$ DMAIC = define, measure, analyze, improve, control 
wised up and developed business continuity plans and more secure and resilient operations (Rice \& Caniato, 2003). They could no longer rely on luck.

"If you can't measure it, you can't manage it" is a quote accredited to several people $^{107}$. Tracking and monitoring should enable management to review both the effectiveness and efficiency of the risk management efforts. There is high utility from such monitoring and subsequent tweaking of the risk management practices for both frequent operational glitches, and infrequent low probability, high impact disruptions. Even though disasters play out differently each time, they represent learning opportunities for future improvement, both with respect to warning systems, prevention efforts and business continuity programs. The ability to learn and improve will build greater supply chain resilience. Closs and McGarrell's guiding thesis in a 2004 paper is that both security and supply chain efficiencies can be maximized, but to achieve this will require changes in thinking, sustained leadership, and continual learning (Closs \& McGarrell, 2004). Having an internal way of detecting and communicating potential hazards - a warning capability - is an important step towards agility and the ability to not only avoid and deflect disruptions, but also recover from the ones that the company cannot escape from.

Implicitly or explicitly, cost-benefit considerations are part of a SCRM monitoring process. Aiming for a risk free existence is expensive and erodes the profitability of the firm. Being better than the competitors in managing the various risks is what is needed

${ }^{107}$ See, for example http://www.quotationspage.com/forum/viewtopic.php?t=225 
for sustained profitability. Being better at risk management entails excelling at identifying and mitigating the risks that could really cause severe damage. The monitoring, controlling and improving processes involve the estimation of the cost impacts (efficiencies) of the mitigation efforts. Several methods are used, including balanced scorecards (Olson, 2012), TCO and NPV ${ }^{108}$ calculations, as well as optimizations comparing the marginal cost of disruption to the marginal cost of mitigation. Most of these types of calculations involve using estimates or forecasts, making them subject to statistical errors and only as good as the assumptions and data used.

For newcomers to a country like India it will take some time to get used to the various risk scenarios encountered there, and it will take time to figure out which mitigation efforts are most useful and economical. It is likely that Indian companies or foreign companies that have been there for a while will have better evolved systems for evading and handling risks. They have adapted to the Indian business and supply chain risk environments. As one of its aims, this dissertation attempts to check whether Indian domicile and/or longevity in the country have any bearing on the negative impacts experienced by supply chain disruptions, and whether there are significant differences in the mitigation methods.

108 TCO = Total Cost of Ownership; NPV = Net Present Value 


\section{CHAPTER 4: RESEARCH OBJECTIVE AND METHODOLOGY:}

In our investigation of which sourcing and production risks are currently encountered in India, what the operational impacts of these risks may have been, what mitigation methods may have been deemed useful, and what the risk expectations are for the future, we performed primary research on the ground in India. A survey questionnaire to a targeted group of at least four thousand high level managers, incl. supply chain professionals, was distributed ${ }^{109}$. The processes of defining risks in a supply chain management context and of refining the MIAMI framework were useful in extracting the right questions to ask and structuring our questionnaire. We also received useful feedback from industry experts practicing in India, as well as the Indian diaspora residing in Seattle.

By running a search on either India supply chain risk or Indian supply chain risk in Google Scholar ${ }^{110}$, the top twenty ${ }^{111}$ search results produced the following works, summarized in Table 15 and roughly in order of appearance ("relevance").

With one exception, all of the twenty papers were conceptual articles that mostly mentioned India as an example to illustrate a point. The paper by Sutton was based on surveys of car manufacturers in China and India, and only six companies in India were polled. Empirical or survey based supply chain management articles based on Indian data are in limited supply, and even more scarce when it comes to the

109 This is an estimated number, as the four supporting organizations guard their membership information closely and were not willing to share exact numbers with us.

${ }^{110}$ Done on January 14, 2013

111 Top twelve from each, but four of them were the same 
emerging field of SCRM. Of the over 400 articles and books we reviewed, quantitative surveys were used only in the papers cited in Table 16. These results are in line with

Table 15: ARTICLE SEARCH RESULTS FOR “INDIA(N) SUPPLY CHAIN RISK":

\begin{tabular}{|c|c|c|c|}
\hline Author: & Title: & Type: & Citation: \\
\hline Faisal, et al. & $\begin{array}{l}\text { Supply chain risk } \\
\text { mitigation: modeling the } \\
\text { enablers }\end{array}$ & Conceptual & $\begin{array}{l}\text { (M. N. Faisal, D. K. } \\
\text { Banwet, \& R. } \\
\text { Shankar, 2006) }\end{array}$ \\
\hline Chopra \& Sodhi & $\begin{array}{l}\text { Managing Risk to Avoid } \\
\text { Supply-Chain Breakdown }\end{array}$ & Conceptual & $\begin{array}{l}\text { (Sunil Chopra \& } \\
\text { Sodhi, 2004) }\end{array}$ \\
\hline Manuj \& Mentzer & $\begin{array}{l}\text { Global supply chain risk } \\
\text { management }\end{array}$ & Conceptual & $\begin{array}{l}\text { (Manuj \& Mentzer, } \\
\text { 2008a) }\end{array}$ \\
\hline Manuj \& Mentzer & $\begin{array}{l}\text { Global supply chain risk } \\
\text { management strategies }\end{array}$ & $\begin{array}{l}\text { Conceptual and } \\
\text { qualitative study } \\
\text { (14 interviews in } \\
\text { the US) }\end{array}$ & $\begin{array}{l}\text { (Manuj \& Mentzer, } \\
\text { 2008b) }\end{array}$ \\
\hline Swaminathan, et al. & $\begin{array}{l}\text { Modeling supply chain } \\
\text { dynamics: A multiagent } \\
\text { approach }\end{array}$ & $\begin{array}{l}\text { Conceptual and } \\
\text { modeling (not } \\
\text { risk focused) }\end{array}$ & $\begin{array}{l}\text { (J.M. Swaminathan, } \\
\text { Smith, \& Sadeh, } \\
\text { 1998) }\end{array}$ \\
\hline Wu \& Olson & $\begin{array}{l}\text { Supply chain risk, } \\
\text { simulation, and vendor } \\
\text { selection }\end{array}$ & $\begin{array}{l}\text { Conceptual and } \\
\text { simulation }\end{array}$ & (Wu \& Olson, 2008) \\
\hline $\begin{array}{l}\text { Trkman \& } \\
\text { McCormack }\end{array}$ & $\begin{array}{l}\text { Supply chain risk in } \\
\text { turbulent environments - } \\
\text { A conceptual model for } \\
\text { managing supply chain } \\
\text { network risk }\end{array}$ & Conceptual & $\begin{array}{l}\text { (Trkman \& } \\
\text { McCormack, 2009) }\end{array}$ \\
\hline Humphrey & $\begin{array}{l}\text { Globalization and supply } \\
\text { chain networks: the auto } \\
\text { industry in Brazil and } \\
\text { India }\end{array}$ & $\begin{array}{l}\text { Case studies (not } \\
\text { risk focused) }\end{array}$ & (Humphrey, 2003) \\
\hline $\begin{array}{l}\text { Giunipero \& } \\
\text { Eltantawy }\end{array}$ & $\begin{array}{l}\text { Securing the upstream } \\
\text { supply chain: a risk } \\
\text { management approach }\end{array}$ & Conceptual & $\begin{array}{l}\text { (Giunipero \& } \\
\text { Eltantawy, 2004) }\end{array}$ \\
\hline Waters & $\begin{array}{l}\text { Supply chain risk } \\
\text { management: } \\
\text { vulnerability and } \\
\text { resilience in logistics }\end{array}$ & Book & (Waters, 2011) \\
\hline Faisal, et al. & $\begin{array}{l}\text { Mapping supply chains } \\
\text { on risk and customer } \\
\text { sensitivity dimensions }\end{array}$ & $\begin{array}{l}\text { Conceptual, } \\
\text { modeling }\end{array}$ & $\begin{array}{l}\text { (M. N. Faisal, D. } \\
\text { Banwet, \& R. } \\
\text { Shankar, 2006) }\end{array}$ \\
\hline Seuring \& Müller & $\begin{array}{l}\text { From a literature review } \\
\text { to a conceptual } \\
\text { framework for }\end{array}$ & $\begin{array}{l}\text { Conceptual, not } \\
\text { risk related }\end{array}$ & $\begin{array}{l}\text { (Seuring \& Müller, } \\
\text { 2008) }\end{array}$ \\
\hline
\end{tabular}




\begin{tabular}{|c|c|c|c|}
\hline & $\begin{array}{l}\text { sustainable supply chain } \\
\text { management }\end{array}$ & & \\
\hline Laeequddin, et al. & $\begin{array}{l}\text { Supply chain partners' } \\
\text { trust building process } \\
\text { through risk evaluation: } \\
\text { the perspectives of UAE } \\
\text { packaged food industry }\end{array}$ & $\begin{array}{l}\text { Conceptual } \\
\text { framework and } \\
\text { survey in United } \\
\text { Arab Emirates }\end{array}$ & $\begin{array}{l}\text { (Laeequddin, } \\
\text { Sardana, Sahay, } \\
\text { Waheed, \& Sahay, } \\
\text { 2009) }\end{array}$ \\
\hline Harland, et al. & Risk in supply networks & $\begin{array}{l}\text { Conceptual, } 4 \\
\text { case studies }\end{array}$ & (Harland et al., 2003) \\
\hline Ellram, et al. & $\begin{array}{l}\text { Understanding and } \\
\text { managing the services } \\
\text { supply chain }\end{array}$ & $\begin{array}{l}\text { Conceptual, not } \\
\text { risk focused }\end{array}$ & $\begin{array}{l}\text { (Ellram, Tate, \& } \\
\text { Billington, 2006) }\end{array}$ \\
\hline Sutton & $\begin{array}{l}\text { The Auto-component } \\
\text { Supply Chain in China } \\
\text { and India-A Benchmark } \\
\text { Study }\end{array}$ & $\begin{array}{l}\text { Surveyed six car } \\
\text { manufacturers in } \\
\text { India }\end{array}$ & (Sutton, 2004) \\
\hline Faisal, et al. & $\begin{array}{l}\text { Supply chain risk } \\
\text { management in SMEs: } \\
\text { analysing the barriers }\end{array}$ & $\begin{array}{l}\text { Conceptual and } \\
\text { model } \\
\text { development }\end{array}$ & $\begin{array}{l}\text { (Faisal, Banwet, \& } \\
\text { Shankar, 2007) }\end{array}$ \\
\hline Rahman & $\begin{array}{l}\text { Use of internet in supply } \\
\text { chain management: a } \\
\text { study of Indian } \\
\text { companies }\end{array}$ & Not risk related & (Rahman, 2004) \\
\hline Jiang, et al. & $\begin{array}{l}\text { An analysis of job } \\
\text { dissatisfaction and } \\
\text { turnover to reduce } \\
\text { global supply chain risk: } \\
\text { Evidence from China }\end{array}$ & $\begin{array}{l}\text { Empirical study } \\
\text { in China }\end{array}$ & $\begin{array}{l}\text { (Jiang, Baker, \& } \\
\text { Frazier, 2009) }\end{array}$ \\
\hline Chopra, et al. & $\begin{array}{l}\text { The importance of } \\
\text { decoupling recurrent and } \\
\text { disruption risks in a } \\
\text { supply chain }\end{array}$ & $\begin{array}{l}\text { Conceptual, } \\
\text { mathematical }\end{array}$ & $\begin{array}{l}\text { (S. Chopra, Reinhardt, } \\
\text { \& Mohan, 2007) }\end{array}$ \\
\hline
\end{tabular}

recent and extensive literature reviews performed by several authors (Ghadge et al., 2011; Monroe et al., 2012; Rao \& Goldsby, 2009; Singhal et al., 2011; Manmohan S.

Sodhi et al., 2012; O. Tang \& Musa, 2011; Vanany et al., 2009; Williams et al., 2008).

32 papers published since 1999 describe empirical research studies pertaining to supply chain risk management (summarized in Table 16 in chronological order). All of these studies considered were survey (questionnaire) based. Another 30 papers 
described studies based on qualitative research techniques, such as case studies,

structured interviews and the Delphi technique.

Table 16: EMPIRICAL RESEARCH STUDIES (SURVEY BASED)

\begin{tabular}{|c|c|c|}
\hline Authors \& Year & Purpose & Sampling frame \\
\hline $\begin{array}{l}\text { (Laios \& } \\
\text { Moschuris, 1999) }\end{array}$ & $\begin{array}{l}\text { Assess the risk of making erroneous } \\
\text { make or buy decisions. }\end{array}$ & $\begin{array}{l}\text { Senior executive with companies } \\
\text { in Greece. } 85 \text { respondents (28\%) }\end{array}$ \\
\hline (Svensson, 2002) & $\begin{array}{l}\text { Develop a set of dimensions of } \\
\text { vulnerability in firms' inbound } \\
\text { logistics flows from their first-tier } \\
\text { suppliers, and the vulnerability in the } \\
\text { firms' outbound logistics flows to } \\
\text { their first-tier customers. }\end{array}$ & $\begin{array}{l}\text { Triangulation through } 2 \text { phases: } \\
\text { Interviews with } 17 \text { Volvo } \\
\text { executives and survey to } \\
\text { managers in the Swedish } \\
\text { automobile industry. } 418 \\
\text { responses }(83.2 \%)\end{array}$ \\
\hline $\begin{array}{l}\text { (Zsidisin \& } \\
\text { Ellram, 2003) }\end{array}$ & $\begin{array}{l}\text { Uses agency theory to assess } \\
\text { management behavior in response to } \\
\text { supply risk and the impact of } \\
\text { detrimental events. }\end{array}$ & $\begin{array}{l}\text { U.S. purchasing professionals } \\
\text { associated with the Institute for } \\
\text { Supply Management (ISM). } 261 \\
\text { responses (28\%) }\end{array}$ \\
\hline $\begin{array}{l}\text { (P. J. Singh et al., } \\
\text { 2005) }\end{array}$ & $\begin{array}{l}\text { Exploratory study with a view to } \\
\text { articulate contemporary supply chain } \\
\text { issues organizations in the industry } \\
\text { face. }\end{array}$ & $\begin{array}{l}\text { Managers from the Australian } \\
\text { automotive industry. } 18 \text { semi- } \\
\text { structured interviews with } 28 \\
\text { managers, then follow-up } \\
\text { seminars. }\end{array}$ \\
\hline (Jüttner, 2005) & $\begin{array}{l}\text { Explore the state of knowledge and } \\
\text { current practices of SCRM, and } \\
\text { examine the business requirements } \\
\text { for assessing and managing SC risks. }\end{array}$ & $\begin{array}{l}\text { Members of the UK-based } \\
\text { Chartered Institute for Logistics } \\
\text { and Transport with an interest in } \\
\text { SCM. } 137 \text { respondents (8\%) }\end{array}$ \\
\hline $\begin{array}{l}\text { (Hendricks \& } \\
\text { Singhal, 2005a, } \\
\text { 2005b) }\end{array}$ & $\begin{array}{l}\text { Investigate the long term stock price } \\
\text { effects and equity risk effects of } \\
\text { supply chain disruptions. }\end{array}$ & $\begin{array}{l}\text { Qualifying companies trading on } \\
\text { U.S. stock exchanges (NYSE, } \\
\text { AMEX, and NASDAQ). The effect } \\
\text { of } 827 \text { disruption } \\
\text { announcements between } 1989 \\
\text { and } 2000 .\end{array}$ \\
\hline $\begin{array}{l}\text { (Blackhurst et al., } \\
2005 \text { ) }\end{array}$ & $\begin{array}{l}\text { Seeks insights into issues within } \\
\text { global sourcing and supply-chain } \\
\text { disruptions, incl. disruption } \\
\text { discovery, recovery, and supply chain } \\
\text { redesign. }\end{array}$ & $\begin{array}{l}\text { U.S. automotive supply chain } \\
\text { executives (case studies), } \\
\text { executives from various } \\
\text { industries (semi-structured } \\
\text { interviews), and focus groups. }\end{array}$ \\
\hline (Fitzgerald, 2005) & $\begin{array}{l}\text { Survey the low-cost country sourcing } \\
\text { strategies (incl. risk mitigation) supply } \\
\text { management executives prioritized } \\
\text { for the next } 3 \text { years (Aberdeen Group } \\
\text { study) }\end{array}$ & $\begin{array}{l}\text { U.S. procurement and supply } \\
\text { chain executives who source in } \\
\text { low cost countries. } 187 \\
\text { enterprises. }\end{array}$ \\
\hline
\end{tabular}




\begin{tabular}{|c|c|c|}
\hline $\begin{array}{l}\text { (Sahay et al., } \\
\text { 2006; Sahay \& } \\
\text { Mohan, 2003) }\end{array}$ & $\begin{array}{l}\text { Assessing whether Indian companies } \\
\text { have aligned their supply chain } \\
\text { objectives with their business } \\
\text { objectives. Found that Indian } \\
\text { companies carry huge inventories. }\end{array}$ & $\begin{array}{l}\text { Senior management of large } \\
\text { member organizations of CII and } \\
\text { ASSOCHAM in India. } 156 \text { valid } \\
\text { responses }(9 \%)\end{array}$ \\
\hline (Smyrlis, 2006) & $\begin{array}{l}\text { Harris Interactive survey of financial } \\
\text { executives on how they perceive and } \\
\text { address risks, including supply chain } \\
\text { disruptions. }\end{array}$ & $\begin{array}{l}600 \text { financial executives from } \\
\text { around the world. }\end{array}$ \\
\hline $\begin{array}{l}\text { (S. Wagner \& C. } \\
\text { Bode, 2006; } \\
\text { Wagner \& Bode, } \\
\text { 2008) }\end{array}$ & $\begin{array}{l}\text { Study SC characteristics as drivers of } \\
\text { SC vulnerability and the relationship } \\
\text { between these drivers and negative } \\
\text { impacts experienced by firms as a } \\
\text { result of SC disruptions. Also, } \\
\text { examine link between SC risk sources } \\
\text { and SC performance. }\end{array}$ & $\begin{array}{l}\text { Top-level German executives in } \\
\text { logistics and supply chain } \\
\text { management. } 760 \text { responses } \\
(15.4 \%)\end{array}$ \\
\hline $\begin{array}{l}\text { (Kocabasoglu, } \\
\text { Prahinski, \& } \\
\text { Klassen, 2007) }\end{array}$ & $\begin{array}{l}\text { Assess the linkages between reverse } \\
\text { supply chain investments, } \\
\text { organizational risk propensity and } \\
\text { business uncertainty. }\end{array}$ & $\begin{array}{l}\text { Plant managers in Canadian } \\
\text { manufacturing companies. } \\
126 \text { respondents }(27 \%)\end{array}$ \\
\hline $\begin{array}{l}\text { (Ferrer, Hintlian, } \\
\text { \& Karlberg, 2007) } \\
\text { (Accenture) }\end{array}$ & $\begin{array}{l}\text { Explore whether corporations have } \\
\text { implemented integrated global } \\
\text { operations strategies and capabilities } \\
\text { (i.e. risk control) while taking } \\
\text { advantage of low-cost sourcing and } \\
\text { manufacturing. }\end{array}$ & $\begin{array}{l}\text { Corporations with revenues of } \\
\$ 500 \text { million or more and with } \\
\text { global operations. } 300 \text { phone } \\
\text { interviews resulted in } 100 \text { usable } \\
\text { responses. }\end{array}$ \\
\hline $\begin{array}{l}\text { (Sadlovska et al., } \\
\text { 2008) }\end{array}$ & $\begin{array}{l}\text { An Aberdeen Group survey to assess } \\
\text { degree of SCRM resilience among } \\
\text { companies. }\end{array}$ & $\begin{array}{l}\text { Online and interview survey of } \\
\text { executives with } 138 \text { companies, } \\
\text { worldwide, but } 63 \% \text { in North } \\
\text { America. }\end{array}$ \\
\hline (Enslow, 2008) & $\begin{array}{l}\text { Asking whether perception of supply } \\
\text { chain risk has increased, whether } \\
\text { financial impact has grown, and } \\
\text { whether firms are prepared. }\end{array}$ & $\begin{array}{l}\text { Survey of } 110 \text { North American } \\
\text { risk managers. }\end{array}$ \\
\hline $\begin{array}{l}\text { (Jiang et al., } \\
\text { 2009) }\end{array}$ & $\begin{array}{l}\text { Identify root causes of job } \\
\text { dissatisfaction leading to turnover } \\
\text { and labor-related supply chain risks } \\
\text { in Chinese factories. }\end{array}$ & $\begin{array}{l}\text { Chinese migrant workers from } \\
\text { different industries and factories } \\
\text { in Guangzhou. } 634 \text { responses } \\
(21.3 \%)\end{array}$ \\
\hline $\begin{array}{l}\text { (Hendricks et al., } \\
\text { 2009) }\end{array}$ & $\begin{array}{l}\text { Examines whether operational slack, } \\
\text { business diversification, geographic } \\
\text { diversification, and vertical } \\
\text { relatedness influence the stock } \\
\text { market reaction to supply chain } \\
\text { disruptions. }\end{array}$ & $\begin{array}{l}\text { Qualifying companies trading on } \\
\text { U.S. stock exchanges (NYSE, } \\
\text { AMEX, and NASDAQ). The effect } \\
\text { of } 307 \text { disruption } \\
\text { announcements between } 1987 \\
\text { and } 1998 .\end{array}$ \\
\hline $\begin{array}{l}\text { (Braunscheidel \& } \\
\text { Suresh, 2009) }\end{array}$ & $\begin{array}{l}\text { Investigates the impact of market } \\
\text { orientation and learning orientation, }\end{array}$ & $\begin{array}{l}\text { Executives who were members of } \\
\text { the Institute of Supply }\end{array}$ \\
\hline
\end{tabular}




\begin{tabular}{|c|c|c|}
\hline & $\begin{array}{l}\text { and three organizational practices on } \\
\text { firms' SC agility for risk mitigation } \\
\text { and response. }\end{array}$ & $\begin{array}{l}\text { Management (ISM), mostly U.S. } \\
218 \text { responses }(7.4 \%)\end{array}$ \\
\hline $\begin{array}{l}\text { (Laeequddin et } \\
\text { al., 2009) }\end{array}$ & $\begin{array}{l}\text { Assessing whether to build trust to } \\
\text { reduce supply chain risk, or reduce } \\
\text { risk to increase supply chain trust. }\end{array}$ & $\begin{array}{l}\text { Senior managers in the UAE } \\
\text { packaged food industry. } 102 \\
\text { respondents. }\end{array}$ \\
\hline (Ellis et al., 2010) & $\begin{array}{l}\text { Investigate the causal relationships } \\
\text { amongst situation, representations of } \\
\text { supply disruption risk, and decision } \\
\text { making within purchasing. }\end{array}$ & $\begin{array}{l}\text { U.S. purchasing managers and } \\
\text { buyers of direct materials (ISM } \\
\text { members). } 223 \text { respondents } \\
(7.1 \%)\end{array}$ \\
\hline $\begin{array}{l}\text { (Arntzen, 2010a, } \\
\text { 2010b) (Arntzen, } \\
\text { 2010c) through } \\
\text { MIT's CTL. }\end{array}$ & $\begin{array}{l}\text { Survey business and supply chain } \\
\text { managers on their opinions about the } \\
\text { importance of risk prevention } \\
\text { compared to response preparedness, } \\
\text { frequency and importance of internal } \\
\text { and external risks, and whether they } \\
\text { have SCR managers or practices. }\end{array}$ & $\begin{array}{l}1,461 \text { valid responses from } 70 \\
\text { countries, including } 65 \text { in India. }\end{array}$ \\
\hline $\begin{array}{l}\text { (Speier et al., } \\
\text { 2011) }\end{array}$ & $\begin{array}{l}\text { Investigate the security actions taken } \\
\text { by firms and the resulting response } \\
\text { to possible disruption threats. }\end{array}$ & $\begin{array}{l}\text { Survey of executives from the } \\
\text { U.S. food industry. } 199 \text { usable } \\
\text { responses (14\%) }\end{array}$ \\
\hline $\begin{array}{l}\text { (Bode et al., } \\
\text { 2011) }\end{array}$ & $\begin{array}{l}\text { Assessing why, how and under what } \\
\text { conditions firms respond to } \\
\text { disruptions, looking for buffering and } \\
\text { bridging strategies. }\end{array}$ & $\begin{array}{l}\text { Survey of sr. supply chain } \\
\text { managers in } 3,945 \text { firms in } \\
\text { Germany, Austria and } \\
\text { Switzerland. } 455 \text { usable } \\
\text { responses }(11.5 \%)\end{array}$ \\
\hline (Rizzon, 2011) & $\begin{array}{l}\text { A.T. Kearney's } 2011 \text { Assessment of } \\
\text { Excellence in Procurement to survey } \\
\text { sourcing and purchasing } \\
\text { performance, incl. risk management } \\
\text { (vulnerability, supply surety, } \\
\text { transportation network frailty, } \\
\text { supplier monitoring, crisis planning } \\
\text { and management) }\end{array}$ & $\begin{array}{l}\text { Executives from more than } 200 \\
\text { companies worldwide, incl. more } \\
\text { than } 20 \text { in Australia, from a } \\
\text { variety of industries. }\end{array}$ \\
\hline (Nguyen, 2011) & $\begin{array}{l}\text { Link key relationship-specific } \\
\text { capabilities (e.g. visibility) to } \\
\text { proactive supplier risk mitigation. }\end{array}$ & $\begin{array}{l}\text { U.S. manufacturing firms } \\
\text { sourcing abroad. } 66 \\
\text { respondents. }\end{array}$ \\
\hline $\begin{array}{l}\text { (Gualandris \& } \\
\text { Kalchschmidt, } \\
\text { 2011) }\end{array}$ & $\begin{array}{l}\text { Assess the relationships among risk } \\
\text { conditions, postponement and firm } \\
\text { perception of supply risks. }\end{array}$ & $\begin{array}{l}\text { Supply chain managers in } \\
\text { medium-sized Italian } \\
\text { manufacturing companies. } 54 \\
\text { respondents (18\%) }\end{array}$ \\
\hline $\begin{array}{l}\text { (Thun \& Hoenig, } \\
\text { 2011) }\end{array}$ & $\begin{array}{l}\text { Analyze the supply chain risk } \\
\text { management practices and } \\
\text { measuring differences between } \\
\text { reactive and preventative SCRM. }\end{array}$ & $\begin{array}{l}\text { Supply chain and logistics } \\
\text { managers at companies in the } \\
\text { German automotive industry. } 67 \\
\text { responses. }\end{array}$ \\
\hline $\begin{array}{l}\text { (Markmann et } \\
\text { al., 2011) }\end{array}$ & $\begin{array}{l}\text { Identify the most relevant topics and } \\
\text { dimensions (changes and challenges) }\end{array}$ & $\begin{array}{l}\text { Security experts (industry, } \\
\text { academia, public sector \& }\end{array}$ \\
\hline
\end{tabular}




\begin{tabular}{|l|l|l|}
\hline & $\begin{array}{l}\text { in SC security management until } \\
2030 .\end{array}$ & $\begin{array}{l}\text { associations) from 25 countries. } \\
80 \text { experts participated in online } \\
\text { Delphi survey. }\end{array}$ \\
\hline $\begin{array}{l}\text { (Vilko \& Hallikas, } \\
\text { 2011) }\end{array}$ & $\begin{array}{l}\text { Illustrate the network relationships } \\
\text { and centrality of different actors in } \\
\text { SCRM. }\end{array}$ & $\begin{array}{l}\text { Managerial practitioners in SCM } \\
\text { in Finland. Structured interviews } \\
\text { with 27 experts, plus panel } \\
\text { discussion. }\end{array}$ \\
\hline $\begin{array}{l}\text { (Kern et al., } \\
\text { 2012) }\end{array}$ & $\begin{array}{l}\text { Assessing whether supply chain risk } \\
\text { identification, assessment, mitigation } \\
\text { and continuous improvement } \\
\text { activities have a positive impact on } \\
\text { supply chain risk performance. }\end{array}$ & $\begin{array}{l}\text { Senior supply chain executives of } \\
\text { medium to large German } \\
\text { manufacturing companies. 162 } \\
\text { responses (14.1\%). }\end{array}$ \\
\hline $\begin{array}{l}\text { (Lavastre et al., } \\
\text { 2012) }\end{array}$ & $\begin{array}{l}\text { Assess attitudes toward risk, tools } \\
\text { used to understand risk, and the } \\
\text { ways in which decisions are made. }\end{array}$ & $\begin{array}{l}\text { General managers and logistics } \\
\text { and supply chain managers in 50 } \\
\text { different French companies. 142 } \\
\text { respondents. }\end{array}$ \\
\hline $\begin{array}{l}\text { (Manmohan S. } \\
\text { Sodhi et al., }\end{array}$ & $\begin{array}{l}\text { Survey supply chain management } \\
\text { researchers on definitional, process } \\
\text { and methodology gaps in the SCRM } \\
\text { literature. }\end{array}$ & $\begin{array}{l}\text { Supply chain management } \\
\text { researchers from worldwide } \\
\text { attending 2009 INFORMS } \\
\text { meeting. 133 responses. }\end{array}$ \\
\hline (Heaney, 2012) & $\begin{array}{l}\text { Aberdeen Group survey of supply } \\
\text { chain visibility practices. }\end{array}$ & $\begin{array}{l}\text { Surveyed 128 enterprises in } \\
\text { North America (64\%), Europe } \\
\text { and Asia-Pacific. }\end{array}$ \\
\hline
\end{tabular}

Only two of the 32 papers in Table 16 performed any sort of empirical survey in $\underline{\text { India }}$ (highlighted above). One, Arntzen and MIT's global risk management practices study, included 65 responses from India out of more than 1,400 valid responses worldwide. The other, Sahay and Mohan's survey, was conducted more than ten years ago, and analyzed whether Indian companies had aligned their supply chain objectives with their business objectives. Their research was less risk oriented, although a byproduct was a finding that Indian companies kept large physical inventories as a precaution.

In February of 2013, the Indian office of the consulting firm AT Kearney published a report summarizing the results of interviews with nearly thirty C-level executives and senior supply chain professionals. This useful report touched upon the complexities and challenges of operating in India, but did not specifically address the 
many supply chain risks and their mitigation (Madhavan, Doshi, Chandra, \& Pansari,

2013).

\section{The Sample Population}

India now has a large enough population of supply chain managers that a

questionnaire-based survey would be appropriate. After traveling to Mumbai at the end of February 2013 and visiting with relevant organizations, the author received

commitments from the following trade associations and chambers to participate in this study:

1. The Bombay Chamber of Commerce and Industry (BCCl)

2. The Indian Merchants' Chamber (IMC)

3. The Indo-American Chamber of Commerce (IACC)

4. Council of Supply Chain Management Professionals (CSCMP) India

5. All India Association of Industries (AIAI)

6. AmCham India

7. World Trade Centre Mumbai

8. U.S. India Importers' Council (USIIC)

The first four organizations (BCCI, IMC, IACC and CSCMP), with a combined membership of several thousand companies, eventually participated fully in the study by sending out e-mail broadcasts to their memberships (or portions of their memberships), containing links to the electronic questionnaire. These four organizations have members that are involved in international trade (sourcing and producing in India), most of whom constitute a highly relevant sampling frame for this study. We feel the target population of managers in India working with upstream supply chain management issues is very well represented with a sampling frame consisting of the full or partial membership rosters of these four organizations. It was not deemed critical 
that the respondents were all supply chain managers, as acceptable and informed answers could also be obtained from people within the organizations involved in general management or the finance function, for example. The mailing lists of the supporting organizations contain mostly top executives of the member companies, ensuring that the questionnaires reached personnel with a strategic and big-picture perspective.

The e-mails sent out by the four supporting organizations contained a brief explanation of the project followed by a link (button style) to the actual questionnaire. In an attempt to standardize the introductory explanations, we provided the organizations with appropriate content that they could copy and paste into their emails. The introductory comments contained no statements or claims that could potentially bias the responses.

The four Indian trade associations sent the e-mail broadcasts out to their members in May and June of 2013. They each sent one reminder out after a few weeks $^{112}$. We closed the survey by the middle of July, 2013.

\section{The Survey Instrument}

The electronic survey instrument (questionnaire) was administered using Qualtrics Survey Software, to which Portland State University is a subscriber. When the Indian managers and potential respondents clicked on the link embedded in the e-mail from one of the trade associations mentioned above, they were automatically routed to our questionnaire lodged on Qualtrics' server. For added credibility, the questionnaire

\footnotetext{
112 When we requested a second reminder be sent out, a couple of the associations balked.
} 
contained the logos of Portland State University and the supporting organization in the top banner. We feel the overall sample design was very appropriate and effective in reaching out to relevant professionals and practitioners dealing with supply chain management issues in India. The responses were completely anonymous. We had no intention or desire to track or identify individual respondents.

A full copy of the questionnaire is attached as Appendix A to this dissertation. The first sixteen questions established the profile of the respondent. These questions answer some of the "MAPPING" concerns (who, what, where, when, etc.) Several options were offered for each question.

Q1. Is your company sourcing in India or producing goods or services in India? Q2. What is your organizational level?

Q3. What is your functional area within the company?

Q4. What is your company's general sector(s)?

Q5. In which country is your company's global headquarters located?

Q6. What is your company's ownership?

Q7. The company... [Owns and operates its own production or development facilities in India] or [Sources from Indian companies] or [Other or none of the above]

Q8. Which businesses are your company involved with globally (incl. India)?

Q9. What are your company's annual global sales in U.S. dollars?

Q10. What kind of activity does your company do in India?

Q11. Which categories of goods or services does your company source or produce in India?

Q12. What is the annual value of what your company is sourcing, producing or developing (incl. services) in India, in Indian Rupees?

Q13. How many persons does your company directly employ in India?

Q14. What percentage of your company's products or services sourced or produced in India is exported out of India (i.e. sold abroad)?

Q15. Where are the locations of your major Indian suppliers and/or your major Indian production facilities (incl. services)?

Q16. For how many years has your company been sourcing or producing in India?

After the initial profiling questions, the respondents encountered a string of four questions meant to measure their recent supply chain disruption experience, the impact 
of the disruptions, whether certain mitigation methods were useful, and which

disruptions they expected to experience the next three years:

1. How many times the past three years (since early 2010) was your Indian supply chain affected by the following supply chain disruptions? (thirteen alternatives were offered here, plus two write-in options) "IDENTIFYING"

2. Please indicate the operational impact of the disruptions you checked in the previous question (the choices offered were no, minor, moderate, major and catastrophic)

"ASSESSING"

3. In your opinion, how useful were these mitigation methods in preventing or limiting the negative impact on your supply chain of the [disruption chosen]? (the mitigation methods we stipulated were buffering, redundancy, flexibility, visibility and insourcing)

"MITIGATING"

4. How frequently do you expect the following disruptions will affect your supply chain in India over the next three years (as compared to the previous three years)? (the same thirteen alternatives were offered here, plus two write-in options)

"IMPROVING"

Questions 2 and 3 (impact and mitigation methods) were only asked for the disruptions the respondents checked in question 1. In structuring this survey and formulating the questions, the methodologies and suggestions outlined in Robert Groves et al. (Groves et al., 2009) and the "Improving Survey Questions" book by Floyd Fowler were found to be useful (Fowler, 1995). The questionnaire went through many iterations and tests before we arrived at the final version.

Beginning with the disruptions discussed in the literature review and listed in Table 12, for our survey instrument the disruptions were limited to thirteen types, as shown in the first column of Table 17. This table also shows how the mitigation methods were simplified based on a careful evaluation of risks reported in India and feedback from experts and practitioners. Five categories of mitigations were included in the survey: buffering, redundancy, flexibility, visibility/collaboration, and insource. 
Table 17: DISRUPTION AND MITIGATION MATRIX

\begin{tabular}{|c|c|c|c|c|c|c|c|c|c|c|c|c|c|}
\hline Mitigation: & $\begin{array}{l}\frac{7}{3} \\
\frac{7}{\pi} \\
\frac{0}{0} \\
\frac{3}{0} \\
\frac{0}{0} \\
\frac{0}{4}\end{array}$ & 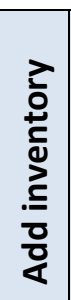 & 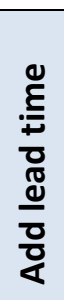 & 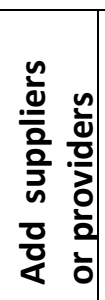 & 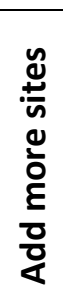 & 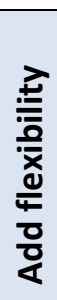 & 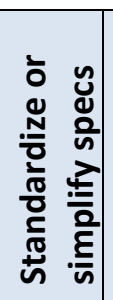 & 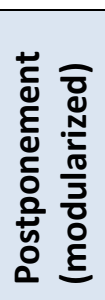 & 这 & 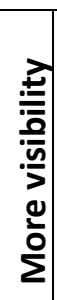 & 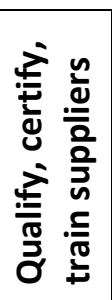 & 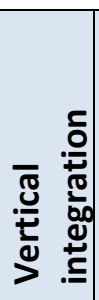 & 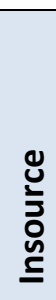 \\
\hline $\begin{array}{l}\text { Flooding and } \\
\text { weather related }\end{array}$ & & & & & & & & & & & & & \\
\hline $\begin{array}{l}\text { Major } \\
\text { Accidents }\end{array}$ & & & & & & & & & & & & & \\
\hline Terrorism, riots & & & & & & & & & & & & & \\
\hline $\begin{array}{l}\text { Transportation } \\
\text { infrastructure }\end{array}$ & & & & & & & & & & & & & \\
\hline $\begin{array}{l}\text { Logistics } \\
\text { infrastructure }\end{array}$ & & & & & & & & & & & & & \\
\hline $\begin{array}{l}\text { Utilities } \\
\text { infrastructure }\end{array}$ & & & & & & & & & & & & & \\
\hline $\begin{array}{l}\text { Property or } \\
\text { violent crimes }\end{array}$ & & & & & & & & & & & & & \\
\hline $\begin{array}{l}\text { Intellectual } \\
\text { property crimes }\end{array}$ & & & & & & & & & & & & & \\
\hline $\begin{array}{l}\text { Corruption or } \\
\text { bribery }\end{array}$ & & & & & & & & & & & & & \\
\hline $\begin{array}{l}\text { Bureaucracy } \\
\text { and red tape }\end{array}$ & & & & & & & & & & & & & \\
\hline Labor problems & & & & & & & & & & & & & \\
\hline $\begin{array}{l}\text { Tax system } \\
\text { problems }\end{array}$ & & & & & & & & & & & & & \\
\hline $\begin{array}{l}\text { Supplier } \\
\text { problems }\end{array}$ & & & & & & & & & & & & & \\
\hline Simplified to: & \multicolumn{3}{|c|}{ BUFFERING } & \multicolumn{2}{|c|}{$\begin{array}{l}\text { REDUN- } \\
\text { DANCY }\end{array}$} & \multicolumn{3}{|c|}{ FLEXIBILITY } & \multicolumn{3}{|c|}{ VISIBILITY } & \multicolumn{2}{|c|}{$\begin{array}{c}\text { IN- } \\
\text { SOURCE }\end{array}$} \\
\hline
\end{tabular}

Guidelines were provided in the questionnaire regarding the five categories

presented:

Buffering: $\quad H a v e$ safety inventories, extended lead times or excess capacity

Redundancy: Have multiple suppliers, sites or equipment

Flexibility: Have suppliers or facilities that can quickly respond, adjust or change over 


\begin{abstract}
Visibility/
collaboration: Collaborate with and get timely information from trusted suppliers, customers and service providers

Insource: $\quad$ Produce and source internally instead of relying on outside suppliers or sources; or integrate vertically
\end{abstract}

An early version of the questionnaire was reviewed by students in a graduate class at the Engineering \& Technology Management Department of Portland State University. They provided critical remarks and very useful feedback for improving the questionnaire and making it less ambiguous. Travels to India in the spring of 2013 were useful in pretesting and obtaining feedback on the survey instrument. We attended a two-day conference of the Indian chapter of CSCMP (Council of Supply Chain Management Professionals), and after many constructive conversations further changes to the survey were made. About twenty of the conference delegates received draft versions of the questionnaire to review. Also, managers with the supporting trade associations were helpful in providing suggestions and feedback. All of these executives were based in India and presumably had a good grasp of the operational realities there. All-in-all, the feeling is that the questionnaire was well vetted before the final version was sent out ${ }^{113}$.

${ }^{113}$ It was suggested by the author's Indian contacts that there is "survey fatigue" in India, and that attention needed to be paid to how the questionnaire was presented to potential respondents. First of all, it should be endorsed by one of more of the organizations, and there should be a way to reward people who completed the questionnaire with something. One of the Indian contacts (a board member of two of the organizations) suggested using live telephone surveyors - for example, Indian college students - to produce a higher response rate. This was an option that was considered, but eventually rejected with the expectation that the e-mail broadcasts went out to a sufficient number of people. 
Statistical validity refers to how well the data measure what they are supposed to measure (Triola, 2008). Using direct and unambiguous questions, we asked the managers to self-report about the construct we are measuring (Indian supply chain risk management, as manifested through risk factors, frequencies, impacts, remedies and expectations). Because of the difficulty (perhaps impossibility) of obtaining objective data on risk severities and mitigation, asking a representative sample of managers about this is an excellent way to measure the underlying risk environment. The assumption is that what is reported is what was experienced. The questionnaire struck a balance between a level of detail and the time demanded of the respondents. We feel that the questionnaire integrated the crucial areas of the construct we intended to measure, and both construct and content validity were achieved. 


\section{CHAPTER 5: FINDINGS AND RESULTS OF THE RESEARCH}

The survey structure resembled the MIAMI template we utilized and discussed in the main body of the dissertation (it is not a perfect resemblance, but very useful as a logical and chronological framework):

- Mapping: Developing a respondent profile, e.g. ownership, size, industry, etc. (questions 2 - 16)

- Identifying: Respondents chose relevant risks and how frequently these were encountered the past three years (a measure of disruption probabilities) (question 17)

- Assessing: To measure impact, respondents indicated how seriously they were affected by the chosen risks (question 18). The frequencies and impacts were subsequently combined into a "severity" score

- Mitigating: Respondents let us know which of five methods were useful in mitigating the identified risks (question 19)

- Improving: Respondents let us know which risks they expect to encounter the next three years, and whether these would occur with greater frequency than in the recent past (from an improving/monitoring standpoint, this may imply that they are somewhat prepared) (question 20)

Based on information from the four cooperating associations, we estimate the email broadcasts went out to 4-5,000 people (but possible more) ${ }^{114}$ (see footnote 109.) 119 people started the survey, but usable responses were only 43 . This is a relatively low number ${ }^{115}$, but because of the length and detail of the questionnaire, we find that the sample still yields a rich amount of valid and high quality information. A total of 4,020 "data points" were collected, which is an average of 93.5 per respondent.

\footnotetext{
${ }^{114} \mathrm{BCCl}$ had 4,539 members as of 3-31-2013; IACC reported "more than 2,000", CSCMP said "almost 1,000 people", and IMC claims more than 3,000. Only a portion of these were engaged in supply chain activities. ${ }^{115}$ An article by Hoskisson et al. discusses various difficulties with sampling and data collection in emerging economies, but we feel that corporate India anno 2013 is fully up to speed in terms of communications and research sophistication. Our problem may have been the length and detail of the self-administered questionnaire, in addition to the issue brought up in the previous footnote (Hoskisson, Eden, Lau, \& Wright, 2000).
} 
This was an exploratory survey, so no pre-survey hypotheses were postulated.

Besides descriptive statistics, the results lent themselves to a certain amount of statistical manipulation such as pairwise comparisons of means, ANOVA (group comparisons) and factor analysis. There was no discernable difference between early and late responses. Of the 43 usable responses, 22 of them submitted their responses in the month of May, and the remaining 21 between June 3 and July 14 . We ran an independent samples t-test, where the two groups (early and late responses) were compared with respect to equality of means and homogeneity of variances. We ran this against the responses to the six most frequent disruptions. Table 18 shows that none of the means or variances were significantly different at the $95 \%$ confidence level.

\section{TABLE 18: OUTPUT FROM SPSS SHOWING NO DIFFERENCES BETWEEN EARLY AND LATE} RESPONSES

\begin{tabular}{|c|c|c|c|c|c|c|c|c|}
\hline \multirow{2}{*}{\multicolumn{2}{|c|}{$\begin{array}{l}\text { Frequencies of six highest } \\
\text { ranked disruptions: }\end{array}$}} & \multicolumn{2}{|c|}{$\begin{array}{c}\text { Levene's Test } \\
\text { for Equality of } \\
\text { Variances }\end{array}$} & \multirow[b]{2}{*}{$t$} & \multirow[b]{2}{*}{$d f$} & \multirow[b]{2}{*}{$\begin{array}{l}\text { Sig. (2- } \\
\text { tailed) }\end{array}$} & \multirow[b]{2}{*}{$\begin{array}{c}\text { Mean } \\
\text { Difference }\end{array}$} & \multirow[b]{2}{*}{$\begin{array}{l}\text { Std. Error } \\
\text { Difference }\end{array}$} \\
\hline & & $F$ & Sig. & & & & & \\
\hline F_Transport & $\begin{array}{l}\text { Equal variances } \\
\text { assumed }\end{array}$ & .314 & .579 & .038 & 40 & .970 & .018 & .480 \\
\hline F_Logistics & $\begin{array}{l}\text { Equal variances } \\
\text { assumed }\end{array}$ & .553 & .461 & -.490 & 39 & .627 & -.224 & .457 \\
\hline F_Utilities & $\begin{array}{l}\text { Equal variances } \\
\text { assumed }\end{array}$ & .000 & .996 & 1.361 & 39 & .181 & .646 & .474 \\
\hline F_RedTape & $\begin{array}{l}\text { Equal variances } \\
\text { assumed }\end{array}$ & .214 & .646 & -.584 & 39 & .563 & -.261 & .447 \\
\hline F_Labor & $\begin{array}{l}\text { Equal variances } \\
\text { assumed }\end{array}$ & 2.235 & .143 & -1.253 & 40 & .217 & -.577 & .461 \\
\hline F_Suppliers & $\begin{array}{l}\text { Equal variances } \\
\text { assumed }\end{array}$ & 2.310 & .136. & .338 & 41 & .737 & .156 & .461 \\
\hline
\end{tabular}


Because some of the supporting organizations sent out the links to the questionnaire later than others, it is impossible to know whether the late responders acted upon the first e-mail, or whether they started the survey after receiving reminders.

When tabulating the results and to obtain high enough sample sizes for meaningful group comparisons, we decided to compress seven of the profile categories asked in the beginning of the survey. We can call these descriptors predictor variables. The first sixteen questions asked factual information about the respondents and the companies. Appendix D shows a summary of the responses to the profile questions. The two questions regarding types of business and categories of products offered up to 22 alternatives, but the responses were too scattered to provide enough observations to perform meaningful analyses of group differences. However, seven of the other questions provided us with answers that could sensibly be lumped into two main groups, with the number of responses shown below in Table 19. When doing this simplification, we tried to arrive at a fairly equal number of respondents in each group, within reasonable bounds.

Possible co-linearity between any of the remaining predictor variables was a concern. For any two variables very closely correlated - for example with coefficients of 0.8 or higher - it makes sense to prune one of them away. It would not add much value to the ensuing statistical analysis and the remaining variable can serve as its "proxy".

Using Kendall's tau (for non-parametric data) and running a correlation matrix with all of the eight variables, it was evident that location of the headquarters and 
ownership were closely and significantly related. The correlation coefficient was .813 and significant at the 0.01 level. We consequently decided to ignore the variable location and let the variable ownership represent both in the subsequent analysis. None of the remaining seven predictor variables were more closely correlated than about .48, and we decided to retain all seven ${ }^{116}$. While working on simplifying the predictor variables, we also ran them through a factor analysis to look for underlying components. It was not surprising that two components were identified: 1) a cluster consisting of sales, value of Indian sourced, number of employed, years in India, and to a lesser extent percentage exported; and 2) a cluster consisting of location and ownership. The former can be dubbed "size" and the latter "Indian". They had eigenvalues of 2.24 and 2.09 respectively, for a cumulative variance explanation of $61.7 \%$. However, we found that the ANOVA and comparison of means gave more meaningful information.

Table 19: SIMPLIFICATION OF THE SEVEN PREDICTOR VARIABLES

1. Question 4: What is your company's general sector(s)?

- Non-durable goods or consumables 8

- Durable goods

- Capital goods

- Natural resources

- $\quad$ Services, incl. IT

8
10
7
6
16

SIMPLIFIED INTO: Goods $\quad 31$ Services $\quad 16$

2. Question 6: What is your company's ownership?

- Fully Indian

- Fully foreign

- Mixed, with majority Indian owned

\section{8}

5

4

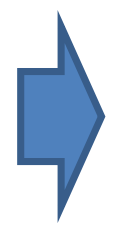

SIMPLIFIED INTO: Indian owned 32 Mixed, with majority foreign owned 6

${ }^{116}$ In Table 32 we added back the "Industry" question to take a closer look at the service sector. 
3. Question 9: What are your company's annual global sales in US dollars?

- Less than $\$ 1,000,000$

- $\$ 1,000,000-\$ 10,000,000$

- $\$ 10,000,000-\$ 100,000,000$

14

- $\$ 100,000,000-\$ 1,000,000,000$

- $\$ 1,000,000,000-\$ 10,000,000,000$

- More than $\$ 10,000,000,000$

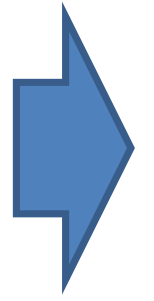

SIMPLIFIED INTO:

Small $(<\$ 10$ mill) 23

Large (>\$10 mill) 17

This grouping compared roughly to the categorization used by the Small \& Medium Enterprise Chamber of India, which defines SME's as companies with an annual turnover less than 25 crore, or about US\$ 4.2 million at current exchange rates.

4. Question 12: What is the annual value of what your company is sourcing, producing or developing in India?

- Less than 10 lakhs

- 10 lakhs to 1 crore

- 1 crore to 10 crores

- 10 crores to 100 crores

- 100 crores to 1,000 crores

- More than 1,000 crores

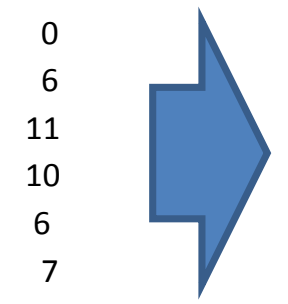

SIMPLIFIED INTO:

Low (<10 crores) 17

High ( $>10$ crores) 23

5. Question 13: How many persons does your company directly employ in India?

- None

- $1-10$

- $11-100$

- $101-1,000$

- $1,001-10,000$

- $10,000-100,000$

- More than 100,000

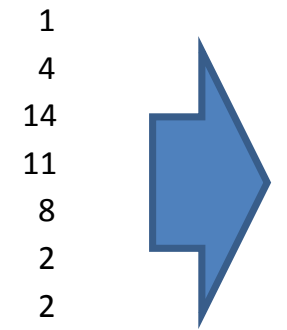

SIMPLIFIED INTO: Few $(<100) \quad 19$ Many $(>100) \quad 23$

6. Question 14: What percentage of your company's products or services sourced or produced in India is exported out of India?

- $100 \%$

- $75-99 \%$

- $50-74 \%$

- $25-49 \%$

- $1-24 \%$

- $0 \%$

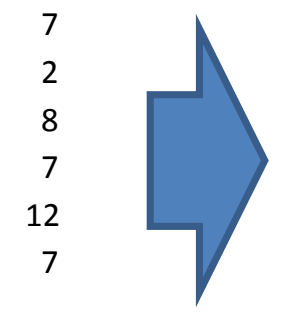

SIMPLIFIED INTO:

High \% $(25 \%+) \quad 24$

Low \% (<25\%) 19

7. Question 16: For how many years has your company been sourcing or producing in India?

- Less than 3 years

- 3-10 years

- $10-20$ years

- More than 20 years

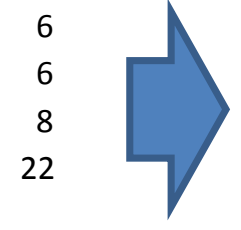

SIMPLIFIED INTO:

Short time $(<20) 20$

Long time $(>20) \quad 22$ 
In this research we are dealing with categorical variables, and in some cases ordered ("ordinal") categorical data.

\section{Summary of Results}

In this section we will review and discuss the findings related to:
a) Frequency of disruptions
b) Impact of disruptions
c) Severity of disruptions
d) Mitigation of disruptions
e) Expected disruptions

\section{a) Frequency of Disruptions}

We asked how many times the past three years the Indian supply chain had been affected by thirteen different categories of disruptions. In addition, responders could write in additional disruptions they may have encountered. Table 20 lists these other disruptions. Many of them we safely reclassified to one of the existing categories, as noted in the last column.

Table 21 lists the thirteen disruptions in the order they appeared on the questionnaire. For most of the disruptions, the "Zero times" alternative was chosen, as those risks were presumably not encountered the past three years. For tabulation, the "10+ times" presents a bit of a dilemma, as the actual number could be from 10 to infinity. For the rest of this analysis, we have chosen a very conservative approach, where "10+" has been interpreted as 10 times. 
TABLE 20: WRITE-INS WITH RESPECT TO FREQUENCIES OF DISRUPTIONS.

\begin{tabular}{|l|l|l|}
\hline OTHER DISRUPTION (verbatim) & $\begin{array}{l}\text { REPORTED } \\
\text { FREQUENCY }\end{array}$ & $\begin{array}{l}\text { WE RECLASSIFIED IT } \\
\text { AS }\end{array}$ \\
\hline Machine Breakdowns & $10+$ times & None \\
\hline Draught & $1-3$ times & $\begin{array}{l}\text { Flooding \& weather } \\
\text { related }\end{array}$ \\
\hline Fluctuating fuel cost. & $7-9$ times & Supplier related \\
\hline $\begin{array}{l}\text { Miscommunication between different logistics } \\
\text { providers (wrong deliveries since no tracking } \\
\text { method provided) }\end{array}$ & $4-6$ times & Supplier related \\
\hline $\begin{array}{l}\text { Qualified human resources } \\
\text { Strike due to Telangana issue in Andhra } \\
\text { Pradesh State }\end{array}$ & No frequency given & $\begin{array}{l}\text { Labor related (1-3 } \\
\text { times) }\end{array}$ \\
\hline Strikes by vendors & $4-6$ times & Labor related \\
\hline Uttarakhad flood this time. & No frequency given & $\begin{array}{l}\text { Flooding \& weather } \\
\text { related (1-3 times) }\end{array}$ \\
\hline Within Department Coordination & $4-6$ times & None \\
\hline $\begin{array}{l}\text { Lack of proper packaging care taken (different } \\
\text { materials have to be handled differently) }\end{array}$ & $4-6$ times & None \\
\hline Rising Inflation & $7-9$ times & None \\
\hline Strikes at ports/IT failure at customs & $4-6$ times & Supplier related \\
\hline $\begin{array}{l}\text { Spare parts Non Availability } \\
\text { No frequency given }\end{array}$ & $\begin{array}{l}\text { Supplier related (1-3 } \\
\text { times) }\end{array}$ \\
\hline
\end{tabular}

Table 22 ranks and summarizes the frequency information in the form of a total number of reported occurrences of each risk, and the weighted average of each. For example, 4.35 times is the average per respondent frequency of disruptions due to insufficient transportation infrastructure over the past three years. To be able to calculate sums and averages, the following logical conversions were applied (keeping in mind the "10+" dilemma):

Zero times $=0$

$1-3$ times $=2$

$4-6$ times $=5$

$7-9$ times $=8$

$10+$ times $=10$ 
Table 21: FREQUENCY OF DISRUPTIONS (in the same order as in the questionnaire):

\begin{tabular}{|c|c|c|c|c|c|c|c|}
\hline Disruption: & Valid & Missing & $\begin{array}{l}\text { Zero } \\
\text { times }\end{array}$ & $\begin{array}{l}1-3 \\
\text { times }\end{array}$ & $\begin{array}{l}4-6 \\
\text { times }\end{array}$ & $\begin{array}{l}7-9 \\
\text { times }\end{array}$ & $\begin{array}{l}10+ \\
\text { times }\end{array}$ \\
\hline $\begin{array}{l}\text { Flooding and weather related } \\
\text { events }\end{array}$ & 40 & 3 & 14 & 23 & 2 & 1 & 0 \\
\hline $\begin{array}{l}\text { Major accidents, incl. fires, } \\
\text { explosions, structural collapses, } \\
\text { or spills }\end{array}$ & 40 & 3 & 25 & 13 & 2 & 0 & 0 \\
\hline Terrorism, riots or civil unrest & 40 & 3 & 30 & 8 & 2 & 0 & 0 \\
\hline $\begin{array}{l}\text { Inadequate or slow } \\
\text { transportation infrastructure } \\
\text { (road, rail, ports or air) }\end{array}$ & 42 & 1 & 11 & 10 & 7 & 4 & 10 \\
\hline $\begin{array}{l}\text { Inadequate logistics } \\
\text { infrastructure (distribution, } \\
\text { warehousing, or cold storage) }\end{array}$ & 41 & 2 & 14 & 6 & 10 & 5 & 6 \\
\hline $\begin{array}{l}\text { Inadequate utilities } \\
\text { infrastructure (electricity, water, } \\
\text { sewer, telephone or internet) }\end{array}$ & 41 & 2 & 14 & 8 & 7 & 4 & 8 \\
\hline $\begin{array}{l}\text { Property or violent crimes } \\
\text { (theft, robbery, hijackings, } \\
\text { vandalism, computer viruses or } \\
\text { fraud) }\end{array}$ & 40 & 3 & 31 & 6 & 1 & 1 & 1 \\
\hline $\begin{array}{l}\text { Intellectual property crimes } \\
\text { (counterfeiting, copyright } \\
\text { violations, or hacking) }\end{array}$ & 39 & 4 & 36 & 2 & 1 & 0 & 0 \\
\hline Corruption or bribery & 41 & 2 & 21 & 10 & 6 & 1 & 3 \\
\hline $\begin{array}{l}\text { Bureaucracy (red tape, unclear, } \\
\text { inconsistent restrictions or } \\
\text { regulations) }\end{array}$ & 41 & 2 & 14 & 10 & 8 & 3 & 6 \\
\hline $\begin{array}{l}\text { Labor problems (strikes, skills } \\
\text { shortages, incompetence, } \\
\text { turnover, absenteeism) }\end{array}$ & 42 & 1 & 12 & 14 & 3 & 4 & 9 \\
\hline $\begin{array}{l}\text { Tax system (burdensome, } \\
\text { arbitrary, or inconsistent) }\end{array}$ & 41 & 2 & 19 & 14 & 3 & 4 & 1 \\
\hline $\begin{array}{l}\text { Supplier problems (quality, } \\
\text { reliability, timeliness, or } \\
\text { financial strength) }\end{array}$ & 43 & 0 & 13 & 10 & 6 & 5 & 9 \\
\hline $\begin{array}{l}\text { Other disruptions written in } \\
\text { (before redistribution) }\end{array}$ & 12 & 31 & 5 & 1 & 3 & 1 & 2 \\
\hline
\end{tabular}


TABLE 22: RANKING, SUMMARY AND AVERAGE OF OCCURRENCES:

\begin{tabular}{|c|c|c|}
\hline Disruption: & $\begin{array}{l}\text { Total } \\
\text { reported } \\
\text { occurrences }\end{array}$ & $\begin{array}{l}\text { Average } \\
\text { occurrences } \\
(n=43)\end{array}$ \\
\hline $\begin{array}{l}\text { Inadequate or slow } \\
\text { transportation infrastructure } \\
\text { (road, rail, ports or air) }\end{array}$ & 187 times & 4.35 times \\
\hline $\begin{array}{l}\text { Supplier problems (quality, } \\
\text { reliability, timeliness, or financial } \\
\text { strength) }\end{array}$ & 180 & 4.19 \\
\hline $\begin{array}{l}\text { Labor problems (strikes, skills } \\
\text { shortages, incompetence, } \\
\text { turnover, absenteeism) }\end{array}$ & 165 & 3.84 \\
\hline $\begin{array}{l}\text { Inadequate utilities } \\
\text { infrastructure (electricity, water, } \\
\text { sewer, telephone or internet) }\end{array}$ & 163 & 3.79 \\
\hline $\begin{array}{l}\text { Inadequate logistics } \\
\text { infrastructure (distribution, } \\
\text { warehousing, or cold storage) }\end{array}$ & 162 & 3.77 \\
\hline $\begin{array}{l}\text { Bureaucracy (red tape, unclear, } \\
\text { inconsistent restrictions or } \\
\text { regulations) }\end{array}$ & 144 & 3.35 \\
\hline Corruption or bribery & 88 & 2.05 \\
\hline $\begin{array}{l}\text { Tax system (burdensome, } \\
\text { arbitrary, or inconsistent) }\end{array}$ & 85 & 1.98 \\
\hline $\begin{array}{l}\text { Flooding and weather related } \\
\text { events }\end{array}$ & 64 & 1.49 \\
\hline $\begin{array}{l}\text { Major accidents, incl. fires, } \\
\text { explosions, structural collapses, } \\
\text { or spills }\end{array}$ & 36 & 0.84 \\
\hline $\begin{array}{l}\text { Property or violent crimes (theft, } \\
\text { robbery, hijackings, vandalism, } \\
\text { computer viruses or fraud) }\end{array}$ & 35 & 0.81 \\
\hline Terrorism, riots or civil unrest & 26 & 0.61 \\
\hline $\begin{array}{l}\text { Intellectual property crimes } \\
\text { (counterfeiting, copyright } \\
\text { violations, or hacking) }\end{array}$ & 9 & 0.21 \\
\hline
\end{tabular}


b) Impact of Disruptions:

The next step in traditional risk assessment and analysis is to estimate the operational and financial impact of the disruptions experienced. The respondents were asked to indicate the operational impact of the disruptions they checked on the question about frequencies. In Table 23, the numbers of respondents in the third column, "Missing", are high because impact data was not asked for disruptions that were not checked (the electronic questionnaire automatically skipped those). In addition, some respondents who checked frequencies did not follow through by indicating the impacts of those disruptions. However, the disruptions with the highest frequencies (Table 21) are also the ones with the highest valid counts in Table 23.

The various impacts were given categorical scores from zero to 4, as follows:

$\begin{array}{ll}\text { No impact }= & 0 \\ \text { Minor impact }= & 1 \\ \text { Moderate impact }= & 2 \\ \text { Major impact }= & 3 \\ \text { Catastrophic impact }= & 4\end{array}$

Table 24 provides a ranking of the impacts, showing average impact scores and an interpretation of these. The calculated scores show the average impact for the respondents who provided impact data (so $n$ varies from 1 to 25 ). In the table, an average impact score of 1.91 is close to 2.0 , which is equivalent to "Moderate impact" on our scale. 
Table 23: IMPACT OF DISRUPTIONS (in the same order as in the questionnaire):

\begin{tabular}{|c|c|c|c|c|c|c|c|}
\hline & & & Imp & & & & \\
\hline Disruption: & Valid & Missing & No & Minor & $\begin{array}{l}\text { Mode- } \\
\text { rate }\end{array}$ & Major & $\begin{array}{l}\text { Cata- } \\
\text { strophic }\end{array}$ \\
\hline $\begin{array}{l}\text { Flooding and weather } \\
\text { related events }\end{array}$ & 18 & 25 & 0 & 11 & 5 & 2 & 0 \\
\hline $\begin{array}{l}\text { Major accidents, incl. } \\
\text { fires, explosions, } \\
\text { structural collapses, or } \\
\text { spills }\end{array}$ & 12 & 31 & 1 & 5 & 4 & 2 & 0 \\
\hline $\begin{array}{l}\text { Terrorism, riots or civil } \\
\text { unrest }\end{array}$ & 6 & 37 & 2 & 3 & 0 & 1 & 0 \\
\hline $\begin{array}{l}\text { Inadequate or slow } \\
\text { transportation } \\
\text { infrastructure (road, rail, } \\
\text { ports or air) }\end{array}$ & 25 & 18 & 2 & 8 & 7 & 8 & 0 \\
\hline $\begin{array}{l}\text { Inadequate logistics } \\
\text { infrastructure } \\
\text { (distribution, } \\
\text { warehousing, or cold } \\
\text { storage) }\end{array}$ & 22 & 21 & 0 & 7 & 10 & 5 & 0 \\
\hline $\begin{array}{l}\text { Inadequate utilities } \\
\text { infrastructure (electricity, } \\
\text { water, sewer, telephone } \\
\text { or internet) }\end{array}$ & 21 & 22 & 1 & 9 & 7 & 4 & 0 \\
\hline $\begin{array}{l}\text { Property or violent crimes } \\
\text { (theft, robbery, hijackings, } \\
\text { vandalism, computer } \\
\text { viruses or fraud) }\end{array}$ & 9 & 34 & 0 & 5 & 2 & 2 & 0 \\
\hline $\begin{array}{l}\text { Intellectual property } \\
\text { crimes (counterfeiting, } \\
\text { copyright violations, or } \\
\text { hacking) }\end{array}$ & 1 & 42 & 0 & 1 & 0 & 0 & 0 \\
\hline Corruption or bribery & 15 & 28 & 1 & 4 & 9 & 1 & 0 \\
\hline $\begin{array}{l}\text { Bureaucracy (red tape, } \\
\text { unclear, inconsistent } \\
\text { restrictions or regulations) }\end{array}$ & 22 & 21 & 1 & 5 & 11 & 5 & 0 \\
\hline $\begin{array}{l}\text { Labor problems (strikes, } \\
\text { skills shortages, } \\
\text { incompetence, turnover, } \\
\text { absenteeism) }\end{array}$ & 24 & 19 & 1 & 8 & 8 & 6 & 1 \\
\hline $\begin{array}{l}\text { Tax system (burdensome, } \\
\text { arbitrary, or inconsistent) }\end{array}$ & 15 & 28 & 2 & 5 & 6 & 2 & 0 \\
\hline
\end{tabular}




\begin{tabular}{|l|l|l|l|l|l|l|l|}
\hline $\begin{array}{l}\text { Supplier problems } \\
\text { (quality, reliability, } \\
\text { timeliness, or financial } \\
\text { strength) }\end{array}$ & 23 & 20 & 2 & 7 & 9 & 5 & 0 \\
\hline $\begin{array}{l}\text { Other disruptions written } \\
\text { in (before redistribution) }\end{array}$ & 13 & 30 & 0 & 1 & 4 & 8 & 0 \\
\hline
\end{tabular}

TABLE 24: RANKING AND SUMMARY OF IMPACT SCORES

\begin{tabular}{|c|c|c|}
\hline Disruption: & $\begin{array}{l}\text { Average } \\
\text { impact }\end{array}$ & $\begin{array}{l}\text { Interpretation of average } \\
\text { score }\end{array}$ \\
\hline $\begin{array}{l}\text { Inadequate logistics infrastructure } \\
\text { (distribution, warehousing, or cold storage) }\end{array}$ & 1.91 & \multirow{7}{*}{ Moderate impact } \\
\hline $\begin{array}{l}\text { Bureaucracy (red tape, unclear, } \\
\text { inconsistent restrictions or regulations) }\end{array}$ & 1.91 & \\
\hline $\begin{array}{l}\text { Inadequate or slow transportation } \\
\text { infrastructure (road, rail, ports or air) }\end{array}$ & 1.84 & \\
\hline $\begin{array}{l}\text { Supplier problems (quality, reliability, } \\
\text { timeliness, or financial strength) }\end{array}$ & 1.83 & \\
\hline $\begin{array}{l}\text { Labor problems (strikes, skills shortages, } \\
\text { incompetence, turnover, absenteeism) }\end{array}$ & 1.80 & \\
\hline Corruption or bribery & 1.69 & \\
\hline $\begin{array}{l}\text { Inadequate utilities infrastructure } \\
\text { (electricity, water, sewer, telephone or } \\
\text { internet) }\end{array}$ & 1.67 & \\
\hline $\begin{array}{l}\text { Major accidents, incl. fires, explosions, } \\
\text { structural collapses, or spills }\end{array}$ & 1.55 & \multirow{4}{*}{ Minor to moderate impact } \\
\hline $\begin{array}{l}\text { Tax system (burdensome, arbitrary, or } \\
\text { inconsistent) }\end{array}$ & 1.53 & \\
\hline $\begin{array}{l}\text { Property or violent crimes (theft, robbery, } \\
\text { hijackings, vandalism, computer viruses or } \\
\text { fraud) }\end{array}$ & 1.50 & \\
\hline Flooding and weather related events & 1.45 & \\
\hline Terrorism, riots or civil unrest & 1.29 & \multirow[b]{2}{*}{ Minor impact } \\
\hline $\begin{array}{l}\text { Intellectual property crimes } \\
\text { (counterfeiting, copyright violations, or } \\
\text { hacking) }\end{array}$ & 1.00 & \\
\hline
\end{tabular}


As can be seen from Table 24, the seven highest ranked impacts represented the same disruptions as the seven highest ranked frequencies, albeit in a slightly different order. They consist of the three infrastructure related risks, labor and supplier problems, the bureaucracy/red tape risk, and corruption/bribery. Figure 4 shows how these cluster on a frequency versus impact chart ("vulnerability map"). The diameter of the circles indicates the number of responses under those risks (the bigger the circle, the more responses were provided under the impact question). The frequency of corruption is low enough that it falls into the "medium" risk cluster, joining the other four risks of taxes, flooding/weather, accidents and crimes. Located in the lower left hand corner, terrorism and intellectual property crimes are not deemed very severe to the participants in this study.

Figure 4 shows a distinct relatively high severity cluster consisting of six risks: the three infrastructure risks (transportation, logistics and utilities), the two risks related to labor and supplier problems, and bureaucracy/red tape.

c) Severity of disruptions ("risk assessment score"):

In this dissertation, severity is the multiplication of two factors, the individual frequency score multiplied by the individual impact score. The "Sum of individual severity scores" in Table 25 is the sum of these multiplications for the respondents where we had both frequency and impact data. The main usefulness of this information is that it signifies how much more the companies have been affected by the top half of the risks than the bottom half. For example, there is an enormous difference in aggregate severity between supplier problems and intellectual property violations, 
FIGURE 3: FREQUENCY VERSUS IMPACT CHART FOR EACH DISRUPTION

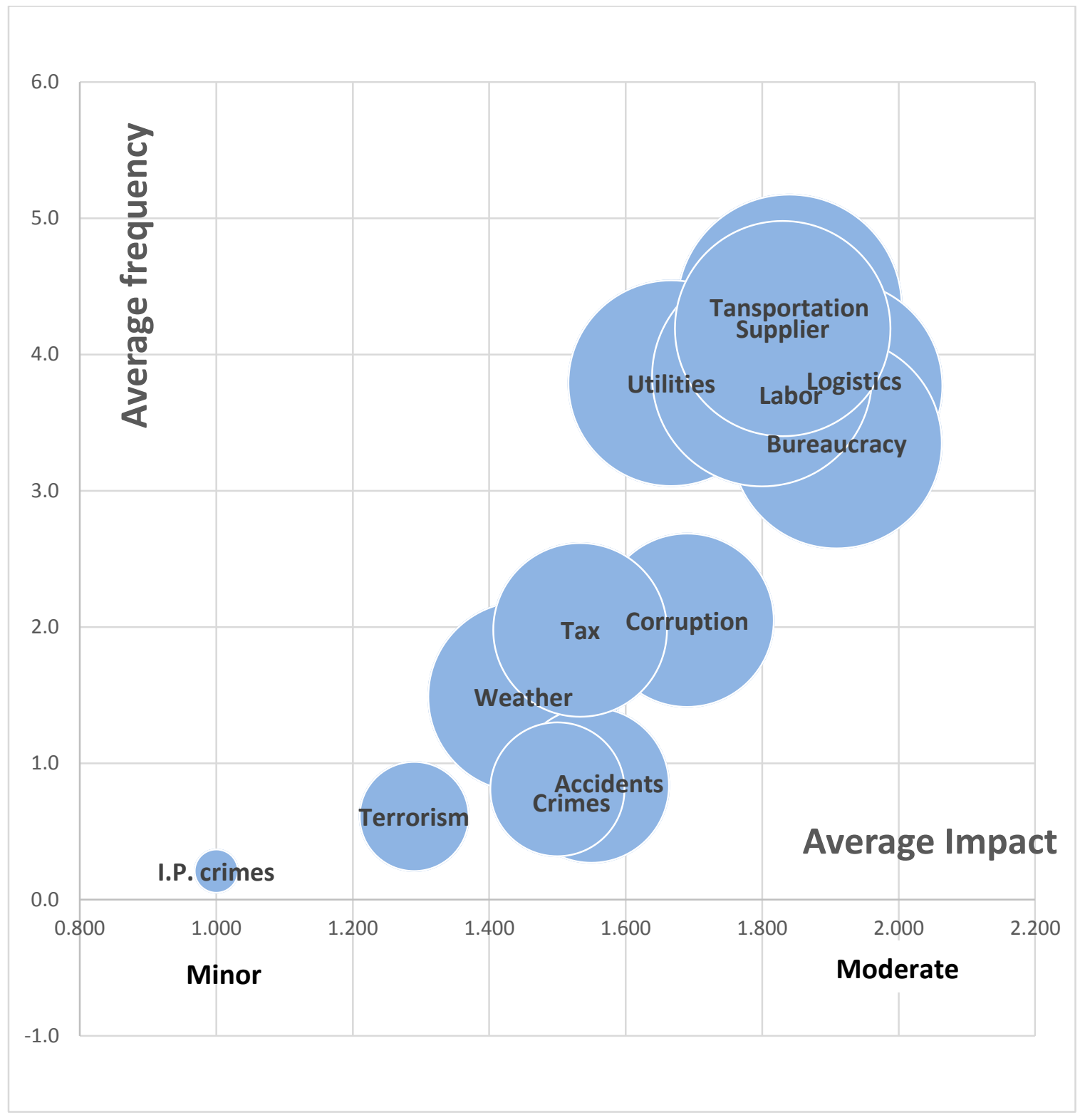

the latter of which in our sample affected only one company. The average scores are calculated for the companies reporting both frequency and impact on any one risk ( $n$ varies from 1 to 25 ). Naturally, the six top risks (shaded) are the ones we recognize from the cluster in the upper right hand corner of Figure 4. 


\begin{tabular}{|l|l|l|}
\hline Disruption: & $\begin{array}{l}\text { Sum of } \\
\text { individual } \\
\text { severity } \\
\text { scores: }\end{array}$ & $\begin{array}{l}\text { Average } \\
\text { severity } \\
\text { (frequency x } \\
\text { impact) } \\
\text { score: }{ }^{117}\end{array}$ \\
\hline $\begin{array}{l}\text { Supplier problems (quality, reliability, timeliness, or financial } \\
\text { strength) }\end{array}$ & 325 & 14.13 \\
\hline $\begin{array}{l}\text { Inadequate logistics infrastructure (distribution, } \\
\text { warehousing, or cold storage) }\end{array}$ & 296 & 14.10 \\
\hline $\begin{array}{l}\text { Inadequate or slow transportation infrastructure (road, rail, } \\
\text { ports or air) }\end{array}$ & 344 & 13.76 \\
\hline $\begin{array}{l}\text { Labor problems (strikes, skills shortages, incompetence, } \\
\text { turnover, absenteeism) }\end{array}$ & 324 & 13.50 \\
\hline $\begin{array}{l}\text { Bureaucracy (red tape, unclear, inconsistent restrictions or } \\
\text { regulations) }\end{array}$ & 254 & 11.55 \\
\hline $\begin{array}{l}\text { Inadequate utilities infrastructure (electricity, water, sewer, } \\
\text { telephone or internet) }\end{array}$ & 235 & 11.19 \\
\hline Corruption or bribery & 133 & 8.31 \\
\hline Tax system (burdensome, arbitrary, or inconsistent) & 90 & 6.00 \\
\hline $\begin{array}{l}\text { Property or violent crimes (theft, robbery, hijackings, } \\
\text { vandalism, computer viruses or fraud) }\end{array}$ & 47 & 5.88 \\
\hline $\begin{array}{l}\text { Intellectual property crimes (counterfeiting, copyright } \\
\text { violations, or hacking) }\end{array}$ & 5 & 5.00 \\
\hline $\begin{array}{l}\text { Major accidents, incl. fires, explosions, structural collapses, } \\
\text { or spills }\end{array}$ & 57 & 3.00 \\
\hline Flooding and weather related events & 76 \\
\hline Terrorism, riots or civil unrest & 21 \\
\hline
\end{tabular}

Not surprisingly, there is a statistically significant difference between the severity of utilities infrastructure (ranked No. 6) and corruption (No. 7). A paired samples t-test produced a t-score of 2.77 and a significance level of 0.02 with 10 degrees of freedom.

117 The reason these scores are not equal to the product of the average frequency and average impact scores is they were calculated with pairwise data, as well as different denominators ( 43 for the frequency averages, and from 1 to 25 for the impact averages) 
The top six, as reported, are significantly more severe than the bottom seven disruptions.

When considering the reported frequencies and impacts, we find that some companies report more frequent and severe disruptions than others. The histogram (density function) in Figure 5 shows a concentration of companies with severity scores of less than 50 , while some reported a variety of risks and accumulated scores of up to about 200. Five companies which reported frequencies of particular risks did not indicate their impacts, resulting in severity scores of zero.

Figure 4: HISTOGRAM OF SEVERITY SCORES

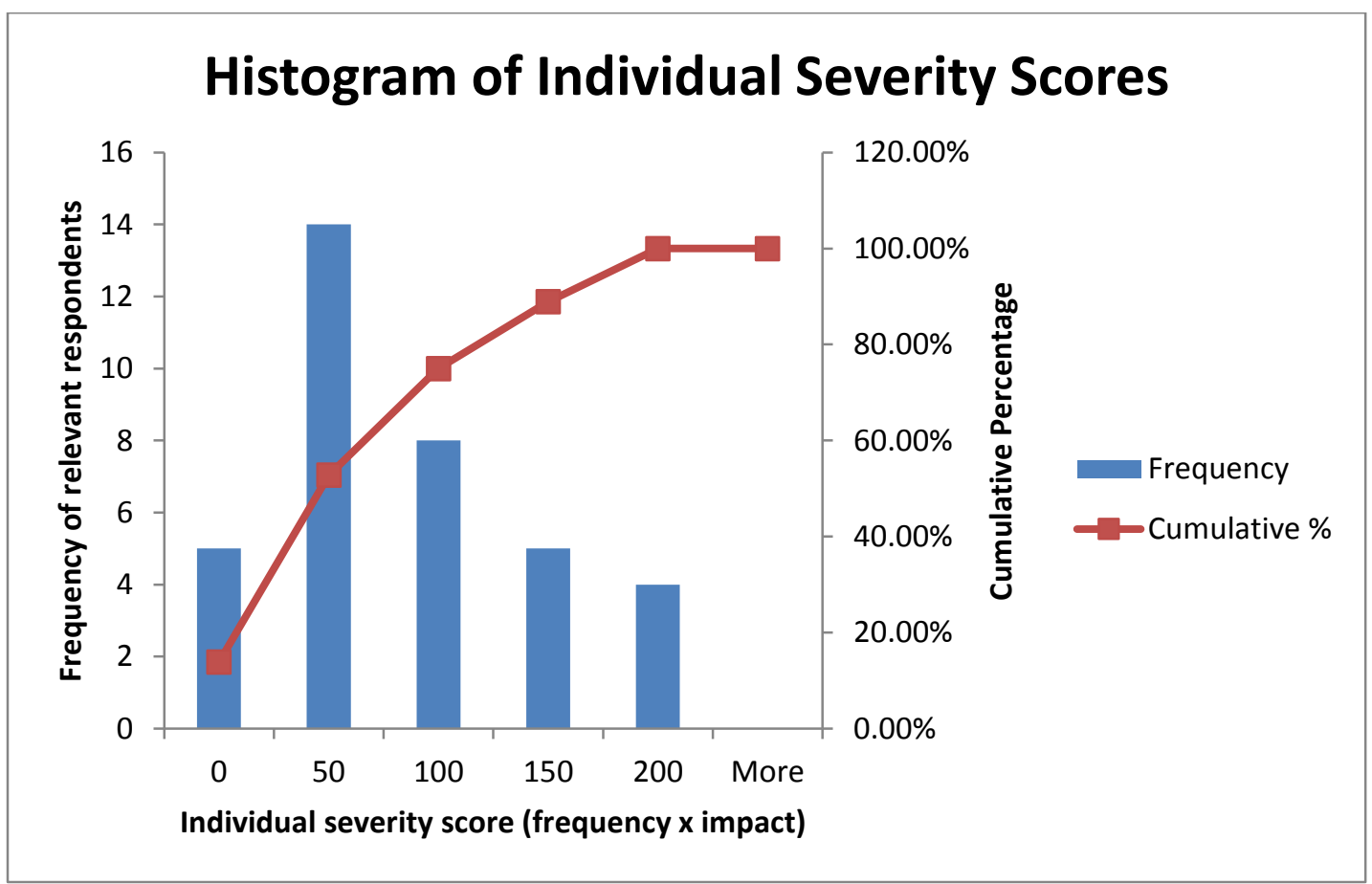

We looked at the profiles of the four respondents with the highest severity scores (the last bar in figure 5), but the characteristics of the four varied a lot. In a later section we will take a closer look at group differences. 
d) Mitigation of disruptions:

This section takes a look at the findings pertaining to the mitigation methods that respondents may have found beneficial or useful in preventing or limiting the supply chain disruptions they previously reported. The discussion around Table 17 explains how we arrived at the five general methods we offered as alternatives.

The question we asked was: "In your opinion, how useful were these mitigation methods in preventing or limiting the negative impact on your supply chain of the [one of 13] problem?" The choices were:

$\begin{array}{llll}\text { Not useful at all } & 0 & \text { Useful } & 2 \\ \text { Somewhat useful } & 1 & \text { Very useful } & 3\end{array}$

The electronic questionnaire only asked for mitigation methods for risks that the respondents had earlier marked with a frequency. Also, some respondents who indicated frequency did not follow up with a responses on the mitigation methods, or gave only partial responses to these questions.

Table 26 summarizes the mitigation method responses by listing the average scores (on the usefulness scale from 0 to 3 ) on each of the five methods offered. The highest score for each disruption is in bold print.

The highest score (2.10 in the first row) was given to redundancy in fixing supplier problems, and can be interpreted as an average usefulness of a tad more than "useful". The average of the weighted average scores was 1.11 , or a smidgen higher than "somewhat useful". The last line shows that on average, buffering and redundancy 
were considered about the same, while flexibility and visibility also had practically

identical average scores. Insourcing scored quite far behind the others.

\section{Table 26: USEFULNESS OF MITIGATION METHODS}

\begin{tabular}{|c|c|c|c|c|c|c|}
\hline & & & verage & Mitigat & on Scol & \\
\hline Disruption: & $\begin{array}{l}\text { Respondents } \\
\text { affected by } \\
\text { this } \\
\text { disruption }(n)\end{array}$ & 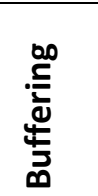 & 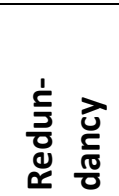 & 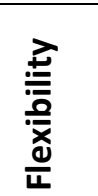 & 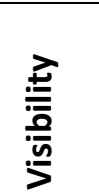 & 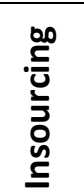 \\
\hline $\begin{array}{l}\text { Supplier problems (quality, reliability, } \\
\text { timeliness, or financial strength) }\end{array}$ & 20 & 1.85 & 2.10 & 1.60 & 1.55 & 1.20 \\
\hline $\begin{array}{l}\text { Inadequate logistics infrastructure } \\
\text { (distribution, warehousing, or cold } \\
\text { storage) }\end{array}$ & 22 & 1.77 & 1.48 & 1.25 & 1.33 & 1.14 \\
\hline $\begin{array}{l}\text { Inadequate or slow transportation } \\
\text { infrastructure (road, rail, ports or air) }\end{array}$ & 24 & 1.67 & 1.43 & 1.43 & 1.57 & 0.83 \\
\hline $\begin{array}{l}\text { Labor problems (strikes, skills } \\
\text { shortages, incompetence, turnover, } \\
\text { absenteeism) }\end{array}$ & 25 & 1.13 & 1.29 & 1.28 & 1.21 & 1.16 \\
\hline $\begin{array}{l}\text { Bureaucracy (red tape, unclear, } \\
\text { inconsistent restrictions / regulations) }\end{array}$ & 21 & 0.62 & 0.67 & 0.76 & 0.76 & 0.57 \\
\hline $\begin{array}{l}\text { Inadequate utilities infrastructure } \\
\text { (electricity, water, sewer, telephone } \\
\text { or internet) }\end{array}$ & 21 & 1.38 & 1.24 & 1.14 & 1.05 & 0.65 \\
\hline Corruption or bribery & 14 & 0.31 & 0.50 & 0.36 & 0.43 & 0.21 \\
\hline $\begin{array}{l}\text { Tax system (burdensome, arbitrary, } \\
\text { or inconsistent) }\end{array}$ & 16 & 0.69 & 0.63 & 0.63 & 0.63 & 0.38 \\
\hline Flooding and weather related events & 21 & 1.52 & 1.20 & 1.35 & 1.15 & 0.50 \\
\hline $\begin{array}{l}\text { Major accidents, incl. fires, explo- } \\
\text { sions, structural collapses, or spills }\end{array}$ & 14 & 1.50 & 1.85 & 1.83 & 1.50 & 0.83 \\
\hline $\begin{array}{l}\text { Property or violent crimes (theft, } \\
\text { robbery, hijackings, vandalism, } \\
\text { computer viruses or fraud) }\end{array}$ & 9 & 0.44 & 0.63 & 0.75 & 1.14 & 0.50 \\
\hline Terrorism, riots or civil unrest & 8 & 1.50 & 1.13 & 0.88 & 1.13 & 0.75 \\
\hline $\begin{array}{l}\text { Intellectual property crimes } \\
\text { (counterfeiting, copyright violations, } \\
\text { or hacking) }\end{array}$ & 2 & 0.50 & 0.50 & 0.50 & 0.50 & 0.50 \\
\hline $\begin{array}{l}\text { WEIGHTED AVERAGE OF } \\
\text { MITIGATION METHODS }\end{array}$ & & 1.25 & 1.22 & 1.15 & 1.14 & 0.77 \\
\hline
\end{tabular}


For the top cluster of six risks, the following methods were found to be the most useful:

TABLE 27: SUMMARY OF MITIGATION USEFULNESS FOR TOP SIX RISKS

\begin{tabular}{|l|l|l|l|}
\hline Disruption: & Mitigation: & Score: & Usefulness \\
\hline Supplier problems & Redundancy & 2.10 & Useful \\
\hline Inadequate logistics infrastructure & Buffering & 1.77 & Useful \\
\hline $\begin{array}{l}\text { Inadequate transportation } \\
\text { infrastructure }\end{array}$ & Buffering & 1.67 & Useful \\
\hline Labor problems & & & \\
\hline Bureaucracy & Redundancy & 1.29 & Somewhat useful \\
\hline Inadequate utilities infrastructure & $\begin{array}{l}\text { Flexibility } \\
\text { Visibility }\end{array}$ & 0.76 & $\begin{array}{l}\text { Somewhat useful } \\
\text { Somewhat useful }\end{array}$ \\
\hline
\end{tabular}

Another way to look at the popularity of mitigation methods is to separate the respondents who found them useful or very useful (i.e. gave them scores of 2 or 3 ). Table 28 shows what percentage of the total respondents found the various methods useful or very useful for the six top ranked risks (top score for each in bold print):

Overall, redundancy has a slight edge on the other five methods, with insourcing in a clear last place. Buffering, redundancy, flexibility and visibility/collaboration are all solidly established and recognized methods for handling supply chain risk. In the survey we asked how useful the various mitigation methods were in preventing or limiting the negative impact of particular risks, and we tend to believe that the answers reflect experiences the respondents have actually had, and not just what they thought might be useful methods. 
Table 28: MITIGATION METHODS DEEMED USEFUL OR VERY USEFUL FOR THE TOP SIX RANKED DISRUPTIONS

\begin{tabular}{|c|c|c|}
\hline Disruption: & Mitigation Method: & $\begin{array}{l}\text { Deemed useful } \\
\text { or very useful: }\end{array}$ \\
\hline $\begin{array}{l}\text { Supplier problems (quality, reliability, } \\
\text { timeliness, or financial strength) }\end{array}$ & $\begin{array}{l}\text { Buffering } \\
\text { Redundancy } \\
\text { Flexibility } \\
\text { Visibility/Collaboration } \\
\text { Insourcing }\end{array}$ & $\begin{array}{l}65 \% \\
76 \% \\
55 \% \\
57 \% \\
35 \%\end{array}$ \\
\hline $\begin{array}{l}\text { Labor problems (strikes, skills shortages, } \\
\text { incompetence, turnover, absenteeism) }\end{array}$ & $\begin{array}{l}\text { Buffering } \\
\text { Redundancy } \\
\text { Flexibility } \\
\text { Visibility/Collaboration } \\
\text { Insourcing }\end{array}$ & $\begin{array}{l}24 \% \\
44 \% \\
42 \% \\
28 \% \\
28 \%\end{array}$ \\
\hline $\begin{array}{l}\text { Inadequate or slow transportation } \\
\text { infrastructure (road, rail, ports or air) }\end{array}$ & $\begin{array}{l}\text { Buffering } \\
\text { Redundancy } \\
\text { Flexibility } \\
\text { Visibility/Collaboration } \\
\text { Insourcing }\end{array}$ & $\begin{array}{l}58 \% \\
52 \% \\
48 \% \\
61 \% \\
22 \%\end{array}$ \\
\hline $\begin{array}{l}\text { Inadequate logistics infrastructure } \\
\text { (distribution, warehousing, or cold storage) }\end{array}$ & $\begin{array}{l}\text { Buffering } \\
\text { Redundancy } \\
\text { Flexibility } \\
\text { Visibility/Collaboration } \\
\text { Insourcing }\end{array}$ & $\begin{array}{l}64 \% \\
52 \% \\
45 \% \\
52 \% \\
36 \%\end{array}$ \\
\hline $\begin{array}{l}\text { Bureaucracy (red tape, unclear, inconsistent } \\
\text { restrictions or regulations) }\end{array}$ & $\begin{array}{l}\text { Buffering } \\
\text { Redundancy } \\
\text { Flexibility } \\
\text { Visibility/Collaboration } \\
\text { Insourcing }\end{array}$ & $\begin{array}{l}14 \% \\
24 \% \\
33 \% \\
33 \% \\
24 \%\end{array}$ \\
\hline $\begin{array}{l}\text { Inadequate utilities infrastructure } \\
\text { (electricity, water, sewer, telephone or } \\
\text { internet) }\end{array}$ & $\begin{array}{l}\text { Buffering } \\
\text { Redundancy } \\
\text { Flexibility } \\
\text { Visibility/Collaboration } \\
\text { Insourcing }\end{array}$ & $\begin{array}{l}43 \% \\
38 \% \\
43 \% \\
38 \% \\
15 \%\end{array}$ \\
\hline $\begin{array}{l}\text { Average "useful" or "very useful" scores } \\
\text { for the six top ranked disruptions }\end{array}$ & $\begin{array}{l}\text { Buffering } \\
\text { Redundancy } \\
\text { Flexibility } \\
\text { Visibility/Collaboration } \\
\text { Insourcing }\end{array}$ & $\begin{array}{l}45 \% \\
48 \% \\
44 \% \\
45 \% \\
27 \% \\
\end{array}$ \\
\hline
\end{tabular}




\section{e) Expected disruptions}

The last portion of the survey asked the respondents to indicate the frequency of supply chain risks they expect to experience over the next three years. Asking what risks to expect implies that the managers are aware of potential upcoming disruptions and that they have somehow taken implicit or explicit steps to minimize them. This fits into the "Improvement" part of the MIAMI template. If nothing else, thinking ahead of which risks may occur should trigger some sort of preparatory moves by management. Of course, the level of preparedness and proactivity vary a lot between firms. As evident from Table 29, of the 43 respondents, between 30 and 33 elected to provide answers to each of our questions about upcoming risks.

While many of the respondents chose to indicate that they did not expect specific risks to happen, the remaining provided risks estimates of frequency (less, same or more). We chose to scale this as follows:

$\begin{array}{lr}\text { Less frequent than previously }= & -1 \\ \text { Same frequency as previously }= & 0 \\ \text { More frequent than previously }= & +1\end{array}$

This will give us a feel for how far from zero (same frequency) the average consensus is for each disruption ${ }^{118}$. The lower the number, the less frequent the risk is expected, relative to the current situation. The disruptions offered are the same thirteen we have used throughout this survey. In addition, respondents could write in additional disruptions they expected.

\footnotetext{
${ }^{118}$ The average of the "less", "same" or "more" responses, excluding the "does not expect".
} 
Table 29: EXPECTED FREQUENCY OF DISRUPTIONS THE NEXT THREE YEARS

\begin{tabular}{|c|c|c|c|c|c|c|}
\hline Disruption: & $\mathbf{n}$ & 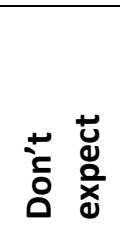 & 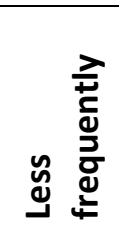 & 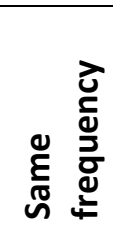 & 这 & 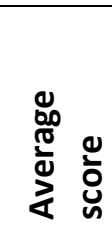 \\
\hline Flooding and weather related events & 30 & 13 & 9 & 7 & 2 & -0.39 \\
\hline $\begin{array}{l}\text { Major accidents, incl. fires, } \\
\text { explosions, structural collapses, or } \\
\text { spills }\end{array}$ & 31 & 17 & 12 & 2 & 1 & -0.73 \\
\hline Terrorism, riots or civil unrest & 31 & 20 & 9 & 3 & 0 & -0.75 \\
\hline $\begin{array}{l}\text { Inadequate or slow transportation } \\
\text { infrastructure (road, rail, ports or } \\
\text { air) }\end{array}$ & 33 & 11 & 15 & 6 & 1 & -0.64 \\
\hline $\begin{array}{l}\text { Inadequate logistics infrastructure } \\
\text { (distribution, warehousing, or cold } \\
\text { storage) }\end{array}$ & 32 & 12 & 15 & 6 & 0 & -0.71 \\
\hline $\begin{array}{l}\text { Inadequate utilities infrastructure } \\
\text { (electricity, water, sewer, telephone } \\
\text { or internet) }\end{array}$ & 31 & 13 & 11 & 7 & 0 & -0.61 \\
\hline $\begin{array}{l}\text { Property or violent crimes (theft, } \\
\text { robbery, hijackings, vandalism, } \\
\text { computer viruses or fraud) }\end{array}$ & 31 & 23 & 6 & 3 & 0 & -0.67 \\
\hline $\begin{array}{l}\text { Intellectual property crimes } \\
\text { (counterfeiting, copyright violations, } \\
\text { or hacking) }\end{array}$ & 31 & 23 & 6 & 2 & 1 & -0.56 \\
\hline Corruption or bribery & 31 & 16 & 7 & 8 & 1 & -0.38 \\
\hline $\begin{array}{l}\text { Bureaucracy (red tape, unclear, } \\
\text { inconsistent restrictions or } \\
\text { regulations) }\end{array}$ & 30 & 12 & 7 & 11 & 1 & -0.32 \\
\hline $\begin{array}{l}\text { Labor problems (strikes, skills } \\
\text { shortages, incompetence, turnover, } \\
\text { absenteeism) }\end{array}$ & 32 & 11 & 10 & 10 & 2 & -0.36 \\
\hline $\begin{array}{l}\text { Tax system (burdensome, arbitrary, } \\
\text { or inconsistent) }\end{array}$ & 32 & 12 & 14 & 3 & 3 & -0.55 \\
\hline $\begin{array}{l}\text { Supplier problems (quality, } \\
\text { reliability, timeliness, or financial } \\
\text { strength) }\end{array}$ & 32 & 12 & 12 & 6 & 2 & -0.50 \\
\hline
\end{tabular}

On average, all thirteen risks were expected to occur less frequently the next three years compared to the past three. But there are differences in the degree of optimism, as Table 30 shows. This lists the disruptions in order of expectation: 
TABLE 30: EXPECTED DISRUPTIONS BY RANK

\begin{tabular}{|c|c|c|}
\hline Disruption: & $\begin{array}{l}\text { Average } \\
\text { score: }\end{array}$ & $\begin{array}{l}\text { \% of Respondents who } \\
\text { expect it same or more: }\end{array}$ \\
\hline $\begin{array}{l}\text { Bureaucracy (red tape, unclear, inconsistent } \\
\text { restrictions or regulations) }\end{array}$ & -0.32 & $40 \%$ \\
\hline $\begin{array}{l}\text { Labor problems (strikes, skills shortages, } \\
\text { incompetence, turnover, absenteeism) }\end{array}$ & -0.36 & $38 \%$ \\
\hline Corruption or bribery & -0.38 & $29 \%$ \\
\hline Flooding and weather related events & -0.39 & $30 \%$ \\
\hline $\begin{array}{l}\text { Supplier problems (quality, reliability, } \\
\text { timeliness, or financial strength) }\end{array}$ & -0.50 & $25 \%$ \\
\hline $\begin{array}{l}\text { Tax system (burdensome, arbitrary, or } \\
\text { inconsistent) }\end{array}$ & -0.55 & $19 \%$ \\
\hline $\begin{array}{l}\text { Intellectual property crimes (counterfeiting, } \\
\text { copyright violations, or hacking) }\end{array}$ & -0.56 & $10 \%$ \\
\hline $\begin{array}{l}\text { Inadequate utilities infrastructure (electricity, } \\
\text { water, sewer, telephone or internet) }\end{array}$ & -0.61 & $23 \%$ \\
\hline $\begin{array}{l}\text { Inadequate or slow transportation } \\
\text { infrastructure (road, rail, ports or air) }\end{array}$ & -0.64 & $21 \%$ \\
\hline $\begin{array}{l}\text { Property or violent crimes (theft, robbery, } \\
\text { hijackings, vandalism, computer viruses or } \\
\text { fraud) }\end{array}$ & -0.67 & $10 \%$ \\
\hline $\begin{array}{l}\text { Inadequate logistics infrastructure } \\
\text { (distribution, warehousing, or cold storage) }\end{array}$ & -0.71 & $19 \%$ \\
\hline $\begin{array}{l}\text { Major accidents, incl. fires, explosions, } \\
\text { structural collapses, or spills }\end{array}$ & -0.73 & $10 \%$ \\
\hline Terrorism, riots or civil unrest & -0.75 & $10 \%$ \\
\hline
\end{tabular}

The risks making up the cluster of six are scattered throughout this ranking. The three least expected to improve (bureaucracy, labor problems, and corruption) are all 
related to human behavior (or misbehavior). For example, as many as 40 per cent expected bureaucracy/red tape to continue at the same or higher frequency. We already found that bureaucracy and labor problems exhibited high severity (frequency $x$ impact), and the expectations are that supply chain managers will continue to be affected by these two risks to a high degree over the next three years. The infrastructure risks (utilities, transportation, logistics) are ranked quite a bit better with respect to future expectations, perhaps reflecting a belief that these impediments are easier to fix through anticipated investments and construction.

Table 31 shows which disruptions the respondents did not expect to experience or expected to experience less over the next three years, ranked in order of the "don't expect" gauge of optimism. The visible disruptions covered by the media (i.e. crimes, terrorism, accidents and to an extent flooding/weather) are apparently not the ones that supply managers expect to encounter or suffer from. The more mundane risks that typically are not written about in the media are the ones that cause operational and financial worries.

By studying tables 29, 30 and 31 closer, one gets the impression that supply chain managers are split on the issue of upcoming risks. This is perhaps not so strange, as every supply chain is different. No firm has the same risk exposure or profile. Future expectations are shaped by the recent experiences of the subjects and what businesses they are in, so a great deal of variation would be expected. 
Table 31: RISKS NOT EXPECTED THE NEXT THREE YEARS:

\begin{tabular}{|l|c|l|}
\hline \multirow{2}{*}{ Disruption } & \multicolumn{2}{|l|}{$\%$ of respondents who } \\
\cline { 2 - 3 } & $\begin{array}{l}\text { Don't expect next } \\
\text { three years }\end{array}$ & $\begin{array}{l}\text { Expect less next three } \\
\text { years }\end{array}$ \\
\hline Crimes & $74 \%$ & $16 \%$ \\
\hline I.P. crimes & $74 \%$ & $16 \%$ \\
\hline Terrorism & $65 \%$ & $25 \%$ \\
\hline Accidents & $55 \%$ & $35 \%$ \\
\hline Corruption & $52 \%$ & $19 \%$ \\
\hline Flooding/weather & $43 \%$ & $27 \%$ \\
\hline Utilities & $42 \%$ & $35 \%$ \\
\hline Bureaucracy & $40 \%$ & $20 \%$ \\
\hline Logistics & $38 \%$ & $43 \%$ \\
\hline Taxes & $38 \%$ & $43 \%$ \\
\hline Suppliers & $38 \%$ & $37 \%$ \\
\hline Labor & $34 \%$ & $28 \%$ \\
\hline Transportation & $33 \%$ & $46 \%$ \\
\hline
\end{tabular}

Some respondents wrote in further comments as to which risks they expected

the next three years (the comments are cited verbatim):

\section{Rising Population}

2. Shipping

3. Debt or finance problems (cost of loans or capital)

4. India has got many potential ways to improve its supply chain infrastructure. Multifaceted problems are faced today and they cannot be attributed to any one factor only. India must work hard and subjugate vested personal interests and must think long-term. Policies to improve infrastructure should be fast-tracked and it must become easy to invite foreign inflows in India (of course keeping welfare of Indian people in mind first)

5. Mitigation methods in preventing or limiting the negative impact MUST BE REDEFINED.

6. Better discipline required

7. Quality human resources

8. Those companies in the middle of Supply Chain get hammered from both ends of the Supply chain-the customers as well as suppliers

9. The impact on our business is not that high. Of course my customers business sometimes major way gets affected. 
Comment number 5 regarding mitigation methods is interesting because it illustrates the potential deficiency in using classic supply chain mitigation methods in fighting socio-economic or cultural impediments such as corruption, bureaucracy and the tax system. Our five suggested mitigation methods are likely most useful for tangible challenges such as delays and damage caused by suppliers or infrastructure problems.

\section{Further Statistical Analysis}

Our findings lend themselves to some interesting statistical evaluations. We will look at:

1) Are there group differences with respect to the severity of disruptions? For example, does it matter whether a company is Indian or foreign owned on how it reported severity? We will use Analysis of Variance (ANOVA) to study this.

2) Are the predictor (profile) variables related or correlated, so that certain combinations of factors (Indian/foreign, small/large, etc.) possess a certain proclivity for severity of disruptions?

3) Can the company profile predict severity of disruptions? We will use multiple regression to study that. ${ }^{119}$

${ }^{119}$ We attempted a dimension reduction by running a Principal Component Analysis using the Factor function in SPSS. Our first run with nine of the disruptions resulted in a "non-positive definite" correlation matrix, due to too few data points for that many variables. We tried again with the top seven disruptions, which gave us results, but did not properly satisfy the KMO (Kaiser-Meyer-Olkin) measure of sampling adequacy (the combined measure was only 0.511 , and none of the coefficients in the anti-image matrix exceeded the recommended 0.5 threshold). We therefore decided against factor analysis on this data. 


\section{Group comparisons}

In Table 19, we kept seven profile variables, each split into two groups. The two groups for each predictor variable were:

- General sector: Goods or Services

- Ownership: Indian or Foreign

- Global sales: Small or Large

- Value sourced: Low or High

- Employed: Few or Many

- Exported: High \% or Low \%

- Years in India: Short time or Long time

In addition, we revisited the data to categorize respondents into two groups:

manufacturing and service. This categorization is somewhat different than the "general sector" above, and is created by putting firms with activities in the first six categories of NIC 2008 into one group, and firms in the remaining 15 activities into another group (see question 8 under Appendix A). Therefore,

- Industry: Manufacturing or Service

Of the 43 respondents, $65 \%$ were found to be representing manufacturing, and the remaining $35 \%$ the service industry.

To check for significant group differences, these eight profile (predictor) variables were compared to the seven disruptions with the most severity, from Table 25 , as well as a summarized assessment variable. This last variable is the sum of the severity scores on all the disruptions for each respondent. The histogram in Figure 5 showed that respondents varied a lot with respect to combined severity over all thirteen disruptions. We find that it makes more sense to run group comparisons on the combined severity scores rather than either the reported frequency or impact scores 
separately. As explained, the severity score is a better measure of overall risk. Table 32

displays the significance levels found after running an ANOVA between the seven

Table 32: CHECKING FOR SIGNIFICANT GROUP DIFFERENCES USING SIGNIFICANCE SCORES

\begin{tabular}{|c|c|c|c|c|c|c|c|c|}
\hline Predictor & $\frac{\frac{.}{2}}{\frac{0}{0}}$ & ㅎํㅁ & $\begin{array}{l}\frac{1}{0} \\
\frac{0}{0} \\
\frac{1}{5} \\
\frac{10}{1}\end{array}$ & 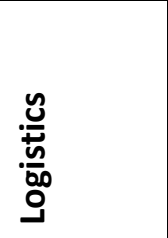 & 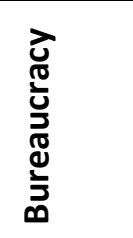 & 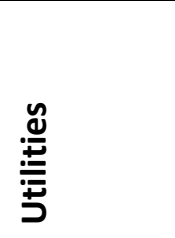 & $\begin{array}{l}\frac{0}{0} \\
\frac{0}{2} \\
\frac{2}{2} \\
0\end{array}$ & 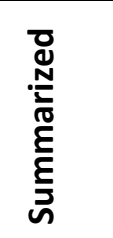 \\
\hline $\begin{array}{l}\text { Sector: } \\
\text { Goods or } \\
\text { Services }\end{array}$ & .176 & .792 & $\begin{array}{l}.072 \\
\text { Services }\end{array}$ & .362 & 909 & .235 & .253 & .110 \\
\hline $\begin{array}{l}\text { Industry: } \\
\text { Manuf. or } \\
\text { Services }\end{array}$ & .320 & .908 & .103 & $\begin{array}{l}.033 \\
\text { Services } \\
120\end{array}$ & .984 & $\begin{array}{l}.094 \\
\text { Services }\end{array}$ & .931 & .298 \\
\hline $\begin{array}{l}\text { Ownership: } \\
\text { Indian or } \\
\text { Foreign }\end{array}$ & $\begin{array}{l}.076 \\
\text { Indian } \\
121\end{array}$ & .720 & .728 & .383 & $\begin{array}{l}.089 \\
\text { Indian }\end{array}$ & $\begin{array}{l}.064 \\
\text { Indian }^{122}\end{array}$ & .404 & .824 \\
\hline $\begin{array}{l}\text { Sales: } \\
\text { Small or } \\
\text { Large }\end{array}$ & $\begin{array}{l}.017 \\
\text { Small } \\
123\end{array}$ & .102 & .124 & $\begin{array}{l}.012 \\
\text { Small } \\
124\end{array}$ & $\begin{array}{l}.001 \\
\text { Small } \\
125\end{array}$ & .425 & .852 & $\begin{array}{l}.070 \\
\text { Small }\end{array}$ \\
\hline $\begin{array}{l}\text { Sourcing \$: } \\
\text { Low or } \\
\text { High }\end{array}$ & .697 & .920 & .331 & .238 & .853 & .680 & .207 & .751 \\
\hline $\begin{array}{l}\text { Employees: } \\
\text { Few or } \\
\text { Many }\end{array}$ & .679 & .947 & .714 & .330 & .698 & .881 & .427 & .975 \\
\hline $\begin{array}{l}\text { Exported: } \\
\text { Hi \% or } \\
\text { Low \% }\end{array}$ & .508 & $\begin{array}{l}.077 \\
\text { Low } \\
\%\end{array}$ & .143 & .960 & .867 & .695 & .144 & .660 \\
\hline $\begin{array}{l}\text { Longevity: } \\
\text { Short or } \\
\text { Long }\end{array}$ & .755 & .802 & $\begin{array}{l}.070 \\
\text { Short }\end{array}$ & .363 & .149 & .923 & .966 & .309 \\
\hline
\end{tabular}

120 This particular group comparison violated the Levene test for homogeneity of variances, with a significance score of 0.049

121 This particular group comparison violated the Levene test for homogeneity of variances, with a significance score of 0.022 .

122 Violation of the Welch robust test for equality of means, with significance score 0.025

${ }^{123}$ Violation of the Welch robust test for equality of means, with significance score 0.011 .

${ }^{124}$ Violation of the Welch robust test for equality of means, with significance score 0.006 .

${ }^{125}$ Violation of the Welch robust test for equality of means, with significance score 0.000 . 
Explanation: Table 32 shows statistical significance scores, where scores lower than 0.10 are considered significant at the $90 \%$ confidence level. Such scores are shown in the lightly shaded boxes, in bold print, followed by the direction of the relationship. For example, the interpretation of the bolded box in the first row is that services sector firms were significantly more affected by transportation disruptions than firms in the goods sector.

predictors and the eight disruption factors. This analysis checks if there is a significant

difference between the severity scores between two groups, for example between companies involved in goods versus companies involved in services. As this is a one-way analysis, values of 0.100 or lower would be statistically significant at the $90 \%$ confidence level. We decided to use the $90 \%$ level because combined with the low sample sizes, the resulting wide confidence intervals give us appropriate guidance for management purposes.

Table 32 indicates 12 significant group differences at the $90 \%$ confidence level:

a) Sector (is the company selling goods or services):

Companies selling services experienced more severe transportation infrastructure disruptions.

b) Industry (is the company in the manufacturing or services industry): Companies in the services industry experienced more severe logistics and utilities infrastructure disruptions.

c) Ownership (is the company Indian or foreign owned):

Companies with Indian or predominantly Indian ownership experienced more severe supplier problems, bureaucracy/red tape, and utilities infrastructure problems.

d) Sales (does the company have small or large global sales, i.e. less or more than US\$ 10 million p.a.):

Companies with small sales experienced more severe supplier problems, more severe logistics infrastructure problems, more bureaucracy/red tape, and were more severely affected overall by supply chain disruptions.

e) Exported (high or low percentage of total sales):

Companies with a low proportion of exports out of India (<25\%) experienced more severe labor problems. 


\section{f) Longevity (long or short tenure in India):}

Companies which have operated in India less than 20 years experienced more severe transportation infrastructure problems.

As for the "Summarized" (last) column in Table 32, it is noteworthy to look at the general direction of the relationships, whether the group differences were significant or not. We already observed that small firms were more prone to disruptions overall (with 93\% confidence), while the other seven factors show:

TABLE 33: DIRECTION OF RELATIONSHIP

\begin{tabular}{|l|l|l|}
\hline FACTOR & GROUP & $\begin{array}{l}\text { Summarized highest disruption } \\
\text { severity experienced by: }\end{array}$ \\
\hline Sector & Goods or Services & Services \\
\hline Industry & Manufacturing or Services & Services \\
\hline Ownership & Indian or Foreign & Indian \\
\hline Sales & Small or Large & Small (SIGNIFICANT; sig = 0.070) \\
\hline Sourcing \$ & Low or High & Low \\
\hline Employees & Few or Many & No difference (sig = 0.975) \\
\hline Exported & Hi \% or Low \% & Low $\%$ \\
\hline Longevity & Short or Long & Short
\end{tabular}

Perusing tables 32 and 33, one gets the impression that by being small, or being Indian owned, or being in the services sector will significantly expose such firms to more supply chain disruptions.

\section{Combinations of Predictor Variables?}

We ran a correlation matrix with the basic seven predictor variables that we used, and found statistically significant correlations (at the $95 \%$ level) between the following four ${ }^{126}$ :

${ }^{126}$ As a correlation coefficient Kendall's tau was used, due to the non-parametric nature and small dataset. 
TABLE 34: SIGNIFICANT CROSS-CORRELATIONS BETWEEN PREDICTOR VARIABLES

\begin{tabular}{|l|c|c|c|}
\hline PREDICTOR & $\begin{array}{l}\text { Value of items } \\
\text { sourced in India }\end{array}$ & Employed in India & Years in India \\
\hline Global Sales & .484 & .564 & .396 \\
\hline $\begin{array}{l}\text { Value of items } \\
\text { sourced in India }\end{array}$ & - & .587 & .327 \\
\hline Employed in India & - & - & .510 \\
\hline
\end{tabular}

This means that companies with high global sales also tend to source heavily in India, have many employees in India, and will have been in India for quite a while. These four variables have a tendency to move in unison. Comparing these findings to the group comparisons in Table 32 does not give us much additional information. It showed that companies with low global sales were more prone to report supply chain problems, including more severe supplier, logistics infrastructure and bureaucracy disruptions. Because of the close correlation with value sourced, Indian employment and tenure in India, it is likely that smaller and younger companies experience more of these problems. Table 34 shows the whole cross-correlation matrix for the predictor variables.

\section{Prediction and Multiple Regression}

The seven predictor variables were run against the summarized severity score as the dependent variable. The purpose was to assess how much of the variability in the summarized severity could be explained from the seven predictors. The first model summary in Table 35 includes all seven predictors and show that the explanatory power (R Square) is $33.9 \%$. However, it is worrisome that the adjusted R square is $17.9 \%$, or only about half. Only two of the slope (beta) coefficients were significant at the $95 \%$ 
TABLE 35: COMPLETE PREDICTOR VARIABLE CROSS-CORRELATION TABLE

Correlations

\begin{tabular}{|c|c|c|c|c|c|c|c|c|}
\hline & & $\begin{array}{c}\text { SECT } \\
\text { OR }\end{array}$ & $\begin{array}{c}\text { OWN } \\
\text { ER }\end{array}$ & $\begin{array}{c}\text { SALES } \\
2\end{array}$ & $\begin{array}{c}\text { VALUE } \\
2\end{array}$ & $\begin{array}{l}\text { EMPLO } \\
\text { YED_2 }\end{array}$ & $\begin{array}{l}\text { EXPOR } \\
\text { TED_2 }\end{array}$ & $\begin{array}{c}\text { YEARS } \\
2\end{array}$ \\
\hline \multirow{3}{*}{ SECTOR } & $\begin{array}{l}\text { Correlation } \\
\text { Coefficient }\end{array}$ & 1.000 & -.021 & .074 & -.005 & .042 & .174 & -.106 \\
\hline & Sig. (2-tailed) & & .892 & .650 & .974 & .793 & .266 & .501 \\
\hline & $\mathrm{N}$ & 42 & 42 & 39 & 40 & 41 & 42 & 41 \\
\hline \multirow{2}{*}{ OWNER } & $\begin{array}{l}\text { Corr } \\
\text { Coef }\end{array}$ & -.021 & 1.000 & .263 & .076 & -.003 & .122 & -.191 \\
\hline & tailed) & $\begin{array}{r}.892 \\
42\end{array}$ & 43 & $\begin{array}{r}.100 \\
40\end{array}$ & $\begin{array}{r}.633 \\
40\end{array}$ & $\begin{array}{r}.987 \\
42\end{array}$ & $\begin{array}{r}.428 \\
43\end{array}$ & $\begin{array}{r}.221 \\
42\end{array}$ \\
\hline \multirow{2}{*}{ SALES_2 } & & .074 & .263 & 1.000 & $.484^{* *}$ & $.564^{\star \star *}$ & -.083 & .396 \\
\hline & tailed) & $\begin{array}{r}.650 \\
39\end{array}$ & $\begin{array}{r}.100 \\
40\end{array}$ & 40 & $\begin{array}{r}.003 \\
39\end{array}$ & $\begin{array}{r}.001 \\
39\end{array}$ & $\begin{array}{r}.606 \\
40\end{array}$ & $\begin{array}{r}.015 \\
39\end{array}$ \\
\hline \multirow{2}{*}{ VALUE_2 } & & -.005 & .076 & $.484^{* *}$ & 1.000 & $.587^{\star \star}$ & -.079 & $.327^{*}$ \\
\hline & $\begin{array}{l}\text { Sig. (2-tailed) } \\
N\end{array}$ & $\begin{array}{r}.974 \\
40\end{array}$ & $\begin{array}{r}.633 \\
40\end{array}$ & $\begin{array}{r}.003 \\
39\end{array}$ & 40 & $\begin{array}{r}.000 \\
39\end{array}$ & $\begin{array}{r}.621 \\
40\end{array}$ & $\begin{array}{r}.044 \\
39\end{array}$ \\
\hline \multirow{3}{*}{$\begin{array}{l}\text { EMPLOYED } \\
22\end{array}$} & tion & .042 & -.003 & $.564^{* *}$ & $.587^{* *}$ & 1.000 & .057 & $.510^{*}$ \\
\hline & Coe & & & & & & & \\
\hline & -tailed) & $\begin{array}{r}.793 \\
41\end{array}$ & $\begin{array}{r}.987 \\
42\end{array}$ & $\begin{array}{r}.001 \\
39\end{array}$ & $\begin{array}{r}.000 \\
39\end{array}$ & 42 & $\begin{array}{r}.714 \\
42\end{array}$ & $\begin{array}{r}.001 \\
41\end{array}$ \\
\hline \multirow{2}{*}{$\begin{array}{l}\text { EXPORTED } \\
-2\end{array}$} & $\begin{array}{l}\text { Corre } \\
\text { Coeff }\end{array}$ & .174 & .122 & -.083 & -.079 & .057 & 1.000 & .100 \\
\hline & $\begin{array}{l}\text { Sig. (2-tailed) } \\
N\end{array}$ & $\begin{array}{r}.266 \\
42\end{array}$ & $\begin{array}{r}.428 \\
43\end{array}$ & $\begin{array}{r}.606 \\
40\end{array}$ & $\begin{array}{r}.621 \\
40\end{array}$ & $\begin{array}{r}.714 \\
42\end{array}$ & 43 & $\begin{array}{r}.521 \\
42\end{array}$ \\
\hline \multirow{3}{*}{ YEARS_2 } & $\begin{array}{l}\text { Correlation } \\
\text { Coefficient }\end{array}$ & -.106 & -.191 & $.396^{*}$ & $.327^{*}$ & $.510^{* *}$ & .100 & 1.000 \\
\hline & Sig. & .501 & .221 & .015 & .044 & .001 & .521 & \\
\hline & $\mathrm{N}$ & 41 & 42 & 39 & 39 & 41 & 42 & 42 \\
\hline
\end{tabular}

confidence level: global sales had a negative coefficient, and employment a positive coefficient. In the bottom panel of Table 35 we ran the regression with only the four relatively highly correlated variables from Table 33 . The adjusted $\mathrm{R}$ square rose a bit, and the same two predictors (global sales and employment) had significant slope coefficients.

With such a low predictive ability, the multiple regression analysis is of limited benefit, if any. It seems that group comparisons using ANOVA and one-way analysis are 
a better way to predict overall supply chain risk severity, at least predictor by predictor. It would be hard to imagine a formula where a company could plug in its profile data and obtain a robust prediction of its supply chain risk exposure. Nevertheless, much of the information uncovered in the many tables above can be of great use.

\section{TABLE 36: MODEL SUMMARIES OF MULTIPLE REGRESSION}

Model Summaryb

\begin{tabular}{|c|c|c|c|c|c|c|c|c|c|c|}
\hline \multirow[t]{2}{*}{ Model } & \multirow[t]{2}{*}{$\mathrm{R}$} & \multirow{2}{*}{$\begin{array}{c}\text { R } \\
\text { Squa } \\
\text { re }\end{array}$} & \multirow{2}{*}{$\begin{array}{c}\text { Adjuste } \\
\text { d R } \\
\text { Square }\end{array}$} & \multirow{2}{*}{$\begin{array}{c}\text { Std. } \\
\text { Error of } \\
\text { the } \\
\text { Estimate }\end{array}$} & \multicolumn{5}{|c|}{ Change Statistics } & \multirow{2}{*}{$\begin{array}{l}\text { Durbin- } \\
\text { Watson }\end{array}$} \\
\hline & & & & & $\begin{array}{c}\text { R Square } \\
\text { Change }\end{array}$ & $\begin{array}{c}\mathrm{F} \\
\text { Change }\end{array}$ & df1 & df2 & $\begin{array}{c}\text { Sig. F } \\
\text { Change }\end{array}$ & \\
\hline 1 & $\begin{array}{r}.582 \\
\mathrm{a}\end{array}$ & .339 & .179 & 51.622 & .339 & 2.125 & 7 & 29 & .073 & 1.461 \\
\hline
\end{tabular}

a. Predictors: (Constant), YEARS_2, EXPORTED_2, SECTOR, OWNER, VALUE_2, SALES_2, EMPLOYED_2

b. Dependent Variable: S_Total

\begin{tabular}{|c|c|c|c|c|c|c|c|c|c|c|}
\hline \multicolumn{11}{|c|}{ Model Summaryb } \\
\hline \multirow[t]{2}{*}{ Model } & \multirow[t]{2}{*}{$\mathrm{R}$} & \multirow{2}{*}{$\begin{array}{c}\mathrm{R} \\
\text { Squar } \\
\mathrm{e}\end{array}$} & \multirow{2}{*}{$\begin{array}{c}\text { Adjuste } \\
\text { d R } \\
\text { Square }\end{array}$} & \multirow{2}{*}{$\begin{array}{c}\text { Std. Error } \\
\text { of the } \\
\text { Estimate }\end{array}$} & \multicolumn{5}{|c|}{ Change Statistics } & \multirow{2}{*}{$\begin{array}{l}\text { Durbin- } \\
\text { Watson }\end{array}$} \\
\hline & & & & & $\begin{array}{c}\text { R Square } \\
\text { Change }\end{array}$ & $\begin{array}{c}\mathrm{F} \\
\text { Change } \\
\end{array}$ & df1 & $\mathrm{df} 2$ & $\begin{array}{c}\text { Sig. F } \\
\text { Change } \\
\end{array}$ & \\
\hline 1 & .555 & .308 & .222 & 50.274 & .308 & 3.565 & 4 & 32 & .016 & 1.308 \\
\hline
\end{tabular}

a. Predictors: (Constant), YEARS_2, VALUE_2, SALES_2, EMPLOYED_2

b. Dependent Variable: S_Total

It is worth stating that any of the correlations we found do not imply causation. For example, small firms do not cause supplier problems. All we can observe is that there are a few statistically significant relationships, as illustrated in Table 32, which may give us an indication of possible exposure rather than any cause and effect associations. 


\section{CHAPTER 6: DISCUSSION OF FINDINGS}

This chapter draws some conclusions from the findings in this study. It will also touch upon additional and supporting information gathered from industry professionals and people familiar with today's India.

Table 37 is a helpful comparison of the frequencies, impacts, severity, most useful mitigation methods, and expected frequency. It is color coded so that the disruptions can be visually tracked.

Table 37: COMPARISON OF RANKING OF FREQUENCY, IMPACT, SEVERITY, MITIGATION AND EXPECTED RISKS

\begin{tabular}{|c|c|c|c|c|c|}
\hline Rank & $\begin{array}{l}\text { Highest } \\
\text { frequency last } \\
3 \text { years }\end{array}$ & $\begin{array}{l}\text { Highest } \\
\text { impact last } 3 \\
\text { years }\end{array}$ & $\begin{array}{l}\text { Highest } \\
\text { severity last } 3 \\
\text { years }\end{array}$ & $\begin{array}{l}\text { Most useful } \\
\text { mitigation } \\
\text { for most } \\
\text { severe risk }\end{array}$ & $\begin{array}{l}\text { Expected least } \\
\text { likely to fall next } \\
3 \text { years }\end{array}$ \\
\hline 1 & $\begin{array}{l}\text { Transportation } \\
\text { infrastructure }\end{array}$ & $\begin{array}{l}\text { Logistics } \\
\text { infrastructure }\end{array}$ & $\begin{array}{l}\text { Supplier } \\
\text { problems }\end{array}$ & Redundancies & Bureaucracy \\
\hline 2 & $\begin{array}{l}\text { Supplier } \\
\text { problems }\end{array}$ & Bureaucracy & $\begin{array}{l}\text { Logistics } \\
\text { infrastructure }\end{array}$ & Buffering & Labor problems \\
\hline 3 & $\begin{array}{l}\text { Labor } \\
\text { problems }\end{array}$ & $\begin{array}{l}\text { Transportation } \\
\text { infrastructure }\end{array}$ & $\begin{array}{l}\text { Transportation } \\
\text { infrastructure }\end{array}$ & Buffering & Corruption \\
\hline 4 & $\begin{array}{l}\text { Utilities } \\
\text { infrastructure }\end{array}$ & $\begin{array}{l}\text { Supplier } \\
\text { problems }\end{array}$ & $\begin{array}{l}\text { Labor } \\
\text { problems }\end{array}$ & Redundancies & Flooding/weather \\
\hline 5 & $\begin{array}{l}\text { Logistics } \\
\text { infrastructure }\end{array}$ & $\begin{array}{l}\text { Labor } \\
\text { problems }\end{array}$ & Bureaucracy & $\begin{array}{l}\text { Flexibility } \\
\text { Visibility (tie) }\end{array}$ & $\begin{array}{l}\text { Supplier } \\
\text { problems }\end{array}$ \\
\hline 6 & Bureaucracy & Corruption & $\begin{array}{l}\text { Utilities } \\
\text { infrastructure }\end{array}$ & Buffering & Tax system \\
\hline 7 & Corruption & $\begin{array}{l}\text { Utilities } \\
\text { infrastructure }\end{array}$ & Corruption & Redundancy & I.P. Crimes \\
\hline
\end{tabular}

Even though supplier problems were not ranked first in frequency or impact, the combined effect caused this risk to place highest in severity. The pairwise multiplication of frequency and impact is the reason for this, illustrating clearly that neither frequency nor impact by themselves are sufficient to fully assess risk. From a management standpoint, severity is what hurts, and both frequency and impact must be controlled. 
The seven top ranked risks are the ones that grind at managers day in and day out. Individually, they are undramatic disruptions that hardly get written about in the newspapers. For supply chain managers, the newsworthy disruptions like terrorism, major accidents and major crimes do not frequently bother them. Although the impact of such events could be catastrophic, they are few and far between, and tend to be insurable. The chronic infrastructure inadequacies, supplier/labor problems, red tape and corruption are ubiquitous impediments that managers operating in India are forced to deal with and find appropriate solutions to. Interestingly, a risk that did not rank highly in the experience ratings - flooding and weather related events - came in fourth as an expected disruption for the next three years. In conversations with industry professionals they expressed a general concern that global climate change would start to affect their operations. Perhaps unease with what is going on with the weather is what elevates this risk factor.

The seven top ranked risks can be lumped onto three main categories:

1) Operational problems internal to the supply chain (supplier and labor problems)

2) Problems due to inadequate infrastructure (transportation, logistics and utilities)

3) Bureaucracy/red tape and corruption

Problems related to suppliers and labor are usually considered internal to a company's extended supply chain, while infrastructure, bureaucracy and corruption disruptions are primarily externally thrust upon a firm. That said, supply chains are not closed systems, and some of the underlying causes of labor and supplier problems may well be problems considered exogenous, such as national labor strikes, road closures 
and shortages of raw materials. The supplier and labor problems embody a complex web of systems, management, technical, cultural and operational glitches and systemic impediments. The risks are also intertwined, meaning that the same disruption (for instance, a late delivery) can be characterized as both a supplier and infrastructure problem. One company's labor problem becomes its customer's supplier problem. The nature of closely coupled supply chains means that disruptions spread beyond the borders of the individual firms.

The fact that the three infrastructure related disruptions did not rank highly in the expectation column either points towards a certain optimism that these are problems that are being remedied and expected to improve, or at least a certain hope that they won't get worse. In a November 2012 statement, India's Minister for Urban Development and Parliamentary Affairs, Kamal Nath, said India will spend USD 1 trillion on infrastructure development in the country over the next five years ${ }^{127}$. The spending on transportation, logistics and utilities has historically been low, so perhaps this represents a bit of a tidal change for the country. Leading business associations, business executives and surveys like these keep reiterating the fact that the infrastructure is deficient, pushing for a greater political will, urgency and ability to allocate more resources to it. Insufficient infrastructure is a substantial drain on the Indian economy and a competitive disadvantage. Executives with a visiting Indian delegation felt that infrastructure problems should be listed as the top future concern,

${ }^{127}$ http://articles.economictimes.indiatimes.com/2012-11-06/news/34946433 1 kamal-nathindia-house-private-sector 
in particular the insufficient transportation infrastructure. Hopefully, what Stanley

Wolpert calls Indians' "general lack of action-mindedness" won't prevail when it comes to these needed infrastructure improvements (Wolpert, 2009).

The results of this survey were presented to several insightful Indian managers and practitioners. These experts were invited to comment on the results and encouraged to contribute background information and suggestions for root causes. The conversations with these experts confirmed the intertwined nature of risks. For example, the visiting delegation of Indian business executives ${ }^{128}$ suggested that labor problems were related to political problems, meaning that political maneuvering often results in strikes and work stoppages. One root cause for labor problems may therefore be political instability and jockeying. In fact, some of the delegates felt that "ineffective political system" should have been included as a separate choice in this survey.

In November of 2013, we presented the findings to another seven industry experts $^{129}$ and asked them to comment on possible root causes and contributing factors. We were especially interested in learning more about underlying dynamics and details surrounding the highly ranked risks of supplier and labor problems. These seven experts on Indian supply chains possessed extensive hands-on experience and knowledge of

\footnotetext{
${ }^{128}$ A delegation of eighteen members of the Mumbai based US-India Importers Council (USIIC) visited Washington State in early November, 2013.

129 Of the seven, six resided in the Seattle area, and one in Bangalore. Two were owners and operators of a mid-sized importing company with extensive and frequent sourcing from India, one was a franchise executive working on setting up U.S. franchises in India, one was an Indian-American software consultant currently working out of Bangalore, one was a commercial lawyer specializing in U.S.-Indian business transactions, one was a leader of an U.S.-Indian trade association, and one was the former Commercial Counselor at the U.S. Embassy in Delhi.
} 
current business conditions in India ${ }^{130}$. Besides what we already knew and have written

about in this study, the communication with the experts resulted in the following useful comments and observations, summarized here in bullet point style:

- None of the seven were surprised that supplier and labor problems were ranked as severe

- The two problems are intertwined, meaning that labor problems may be behind the purported supplier problems

- Structurally, Indian manufacturing is quite labor intensive, meaning that relationship and union issues are always at the forefront

- Strong growth in sales and orders causes "growing pains", meaning that suppliers, especially small and medium sized businesses, are not able to keep up with customer demand and provide good service

- The growth in orders has several negative effects, including difficulty of finding or retaining qualified labor, corner cutting and lowering of overall quality, "sacrifice" of smaller customers if somebody bigger comes along with a major order (smaller importers compete against the large, international buyers, like chain stores)

- Many of these large, international importers negotiate so hard on prices and terms that quality eventually suffers

- Many Indian export articles are still hand-made and produced locally in small factories. Most of the producers have capacity limits and a hard time scaling up their operations

- It is becoming more difficult for these firms to recruit younger workers willing to work with their hands in relatively low-paid positions, as many seek white collar jobs in the cities

- The strong growth has caused a lack of managerial experience, skills and talent. Managers are often not properly empowered, and are frequently distrusted by workers

- Small and mid-sized firms find it difficult to obtain the necessary financing to expand and automate their operations, including procuring machinery that would improve output and quality

- Infrastructure problems pay a certain role, and the lack of sufficient warehousing, transportation hubs and other facilities make it harder for suppliers to deliver

- There exists an educational gap in India, with a lack of vocational and trade programs to educate and prepare workers in emerging and growing industries

${ }^{130}$ The main forum was a working luncheon with five of the experts, while the input from the remaining two were obtained through a personal meeting and a Skype conversation. 
- Larger companies are more prone to being affected by politically motivated labor strikes and other union actions

- The definition of "inadequate" (as used to characterize the transportation, logistics and utilities infrastructure) in our questionnaire is subjective, and raises the question "compared to what?"

Their suggestions for alleviating some of these risks include maintaining close relationships with trusted suppliers, ensuring worker loyalty and creating a feeling of family among employees, making frequent visits to suppliers' factories, and having a quality control or inspection mechanism in place before items are exported out of India. Also, competitive advantage can often be maintained by cultivating close bonds with suppliers manufacturing unique and high quality niche products. Cost pressures and commoditization efforts will fuel quality and delivery problems. One expert also suggested that businesses not focus so much on changing India as on changing their management and operating procedures when doing business there. India undoubtedly needs to change to remain competitive in the global business environment. However, this expert did raise a good point regarding the requisite resilience that is required to successfully navigate the Indian business landscape. To thrive and survive, businesses do what they have to do in the environment that surrounds them.

Depending on the nature of "internal" problems such as supplier and labor disruptions, a piece of good news is that they might be fixable with better management and internal control systems. Supplier and labor problems are not unique to India, and more sophisticated management structures and I.T. systems may help in alleviating them. As one of the experts commented, all companies operating in India are faced with the same set of supplier and labor problems, and this constitutes a "level playing field" 
amongst competitors. The winners will be the companies best able to manage and mitigate the various operational risks. However, we have seen from the data in this survey that there are differences in how categories of companies perceive risk, as manifested through frequencies and impact. Notably, and as seen in Table 32, Indian owned companies reported significantly more severe supplier, bureaucracy and utilities problems, while smaller companies were more severely affected by supplier, logistics, bureaucracy and overall disruptions. Companies doing services were also more prone to experience risks. We can only make educated guesses as to why this is so. Somewhat counterintuitively, being Indian owned does not seem to be of benefit in repelling problems, and small firms report being bothered more than large firms with respect to disruption severity. Perhaps the ownership of the firm is of little relevance in managing local risks, as most of the managers are Indian anyway whether the firm is Indian or foreign. Whether large and/or foreign firms are able to hire and pay for better managers remains an issue that our survey cannot answer. Whether foreign firms interpret risks differently than Indian firms is another interesting question, but we don't have enough information in this study to verify whether this implies some sort of cultural difference.

The respondents to this survey suggested that redundancies would be the best mitigation method for both supplier and labor disruptions. Redundancies imply having multiple suppliers, sites or equipment, rendering the company with available backup capabilities. Possessing redundancies is usually costlier than single source, but in the long run considered economically wiser from a risk management standpoint. The other stalwart, buffering (holding inventory and adding lead times) was popular for the 
logistics and utilities infrastructure problems. Overall, the four methods of buffering, redundancies, flexibility and visibility/collaboration ranked very closely in perceived usefulness ( $44 \%$ to $48 \%$ of the respondents ranked them useful or very useful), while insourcing was not highly ranked. The latter is possibly a more strategic step, which puts it out of immediate reach for most supply chain managers dealing with operational issues. It is also worth keeping in mind the feedback we got on the relevancy of our five suggested mitigation methods with respect to some of the more pesky risks encountered in India, like bureaucracy, the tax system and corruption. Holding inventory or having several suppliers are hardly the best methods for circumventing red tape and bribery. The respondent who added the note did not suggest suitable mitigation steps for these non-physical problems, but it is evident that the supply chain manager's classic tool box may be lacking suitable methods for dealing with such impediments.

If we check back with Table 14 ("How recent surveys ranked sources of disruption"), we see that three of those global studies ranked labor and supplier disruptions on top (the fourth had utilities infrastructure ranked first). The results of our research, therefore, seem consistent with major global studies performed by multinational consulting or insurance companies. We are the first study which specifically looked at India. Paradoxically, the consultancy A.T. Kearney in a 2010 study gave India the best relative score in "people skills and availability", which was quantified as “suppliers' experience and skills, labor-force availability, education and language proficiency, and attrition rate" (Cavusgil, Knight, \& Riesenberger, 2011). The same 
consulting firm, however, this year downgraded India in their bi-annual Foreign Direct Investment Confidence Index. While holding the second best ranking in 2005, 2007, and 2012, India fell to fifth place in 2013 (Kearney, 2013).

Bureaucracy and corruption placed lower than some of our experts would have thought. This may have to do with the profile of our respondents, who mostly dealt with supply chain problems. It is possible that they were less involved with management situations exposing them to activities typically susceptible to bureaucracy and bribery, such as bidding processes, sales, licensing and permitting.

As discussed, dramatic, Black Swan events did not flourish in our sample. One manager commented that the 2008 Mumbai terrorist attacks did not slow down business or supply chains at all. It certainly slowed down public transportation for a few days and tourism for a great deal longer, but from a purely operational supply chain standpoint, terrorism against soft targets tends to be of lesser concern. It was also encouraging to see that our sample was not affected by major crimes or intellectual property (IP) violations. Although IP violations are most commonly associated with China, India has for several years appeared on the U.S. Trade Representative's Priority Watch List for intellectual property violations, with nine other countries (Marantis, 2013). Because IP infringements are not directly physical or necessarily acute problems, they may not often rise to the attention of supply chain managers.

Some of the visiting delegates felt that the category "flooding or weather related problems" was a bit too limiting, and suggested a broader label such as "climate change problems" or "environmental impact". They speculated that perhaps the responses to 
the flooding question could have been influenced by the timing of the survey. The presence and immediacy of the annual monsoon season may have colored the responses. The survey was distributed in May-July, which is usually in the midst of this season, but flooding was still not listed as a top risk. Thus it appears seasonality was not a problem with respect to this question.

If there is a silver lining to the fact that supplier, labor and infrastructure disruptions were found to be the most severe supply chain problems, it may be that country experience and skillful management practices go a long way in remedying them. Supply chain managers have to be resourceful, diplomatic and smart when navigating the every-day business climate and impediments found in India. Companies with talented local management should be able to succeed and gain competitive advantage in this environment. In a recent report, the well regarded firm company Kohlberg Kravis Roberts stated that India would not achieve its full potential until it does at least three things better, and the first thing listed was "invest more in infrastructure" (KKR, 2012). The interconnected nature of many of India's challenges means that a seriously upgraded physical infrastructure should help reduce other problems, such as supplier reliability and corruption.

\section{Significance, Contribution and Limitations of this Work}

With its resources, India will continue to grow as a supplier of goods and services to the world. This dissertation has outlined a method for treating supply chain risk management by applying a template called MIAMI for analyzing risks in India. MIAMI is 
an acronym for mapping, identifying, assessing, mitigating and improving. We decided to use the template in a somewhat modified form to conduct an empirical survey of supply chain risks in India, with particular emphasis on the upstream portion (sourcing and operations). While a few international studies were useful in formulating our survey questions, only three studies partially touched upon our subject area and India (Arntzen, 2010a, 2010b, 2010c; Madhavan et al., 2013; Sahay et al., 2006; Sahay \& Mohan, 2003). These studies kept the emphasis at a more general and strategic level, and did not specifically drill into supply chain risk frequencies, impacts, mitigation methods or expectations. Ours is the only study so far to query supply chain managers about these fairly detailed risk considerations, and is the only study to present a current picture of supply chain risk severity in India.

The utility of the study is evidenced by the fact that it gives supply chain managers crucial information on which risks to expect while operating in India, and an assessment of the severity of these risks. This information will prove useful in preparing for and managing the day-to-day challenges of this complex business environment.

We set up an empirical survey using the practical MIAMI framework to frame the questions and ensure construct validity. A significant contribution lies in the fact that we have uncovered Indian supply chain risks and their severities by querying supply chain managers on the ground in India. The outcome of the study revealed some unexpected and also not-so-surprising results. For instance, it is noteworthy that companies are most severely affected by the chronic, relatively low-grade risks of inadequate infrastructure, supplier and labor problems, and bureaucracy. None of the highly 
publicized risks of natural disasters, terrorism, accidents and serious crimes were ranked highly overall. The significance of this from a management standpoint is that competent, day-to-day management will go a long way in remedying the chronic, societal risks.

We had great cooperation from four leading trade associations in India, and they were willing to send links to our questionnaire out to their members. However, even after reminders, we were only able to garner 43 usable responses, for a very low response rate. These organizations guard their membership data closely, and did not share with us how many people the broadcasts went out to. We believe 5,000 or so may be a realistic number. 119 people started the survey, but perhaps they discontinued after realizing the level of detail and the time it would take to complete it properly. A complete survey would take about 15-30 minutes to do, and that is too long for most busy practitioners. Regardless, the 43 responses gave us a rich amount of data, and we feel the sample is representative of the target population of supply chain managers.

On disruption severities, please keep in mind a few dilemmas or limitations:

\section{1) The open-endedness of frequencies of 10+:}

If somebody wanted to report that a risk happened 36 times in the past three years, we were limited to record that as 10 times, thus understating the frequency or likelihood of any such risks. If a disruption did happen 36 times it would presumably have a minor or moderate impact, as it would be difficult for any organization to survive or stomach major or catastrophic disruptions on a monthly basis. 


\section{2) Individual or combined impacts:}

Do the reported impacts pertain to each and every of the reported frequencies, or did the respondents report the aggregate impact? For example, if a company experienced eight risks within the three-year period, did they all have a moderate impact, or were they eight minor disruptions that combined produced a moderate or major impact ("death by a thousand cuts")? Ideally, a survey would ask for the specific impact of each and every event, but getting into such detail would require a different type of investigative tool, probably more akin to an audit.

\section{3) Subjectivity when assessing and comparing impact:}

Somebody risk averse with a low threshold may have stipulated "major" on a risk that another would characterize as "minor". We did not ask the respondents to provide monetary impact estimates, which may have given us a more objective comparison (and an even longer questionnaire to complete). However, as we discussed earlier, risk assessments are highly subjective by nature, so perhaps leaving the severity estimates without clear benchmarks is fine after all. Statistical averaging tends to even out individual proclivities for over or understating.

\section{4) The scaling problem:}

How do you compare a catastrophic disruption to a minor disruption? Using our scale it may seem like a catastrophe is only five times more serious than a minor event, while in reality it could be thousands of times worse from a financial and operational standpoint. We elected not to assign arbitrary values to weigh the various impacts, so a plain ranking from 0 to 4 is what we stayed with. The benefit of not inflating major or 
catastrophic impacts is that we avoid suffocating the rest of the data, thereby making everyday disruptions seem insignificant. Again, at the risk of too lengthy a survey, maybe monetary impacts should have been asked for.

Because our survey covers a variety of business sectors and industries, and with only a few respondents representing each, it is difficult to use the results to detect differences down to such a detailed level. For example, segments of the Indian I.T. industry are considered world class, but this survey does not have enough I.T. firms responding - only 4 - to justify any conclusions. A limitation of this research is its coarseness, and that only the eight general group comparisons we looked at in tables 32 and 33 would be meaningful.

We suggest that further research on the topic of Indian supply chain risks attempts to segregate both the industry sectors and the risk categories. Ours is a broad study, while what seems needed now is detailed research into particular risks affecting particular sectors. For example, combined with quantitative surveys, qualitative research such as case studies and interviews can be used to unearth problems relevant to important sectors of the Indian economy. Case on point: It seems appropriate to investigate and decipher underlying elements and causes of the intertwined supplier and labor risks. If this is done in a sectorial context (e.g., I.T.), it would shed important light on exposures and provide platforms for effective remedies. 


\section{CHAPTER 7: CONCLUSIONS AND RECOMMENDATIONS}

This dissertation helps fill an information gap regarding supply chain risks in the emerging nation of India. By performing a quantitative, empirical study we have established certain traits based on the hands-on experience of Indian supply chain manager and experts. Focusing on the upstream portion of the supply chain, we uncovered which disruptions have the highest frequency, impact and ensuing severity. We have explored which mitigation methods were the most useful in alleviating the risks. Lastly, we gathered information on which risk factors the supply chain profession expects to encounter over the coming three years.

We built our research approach on a modified version of a time tested model for risk management and control. The stepwise and logical methodology of MIAMI mapping, identifying, assessing, mitigating and improving - was found immensely useful in structuring the survey. The questionnaire was built around the MIAMI framework and roughly asked five main questions:

1. Tell us about your Indian supply chain (Mapping)

2. What went wrong in your supply chain? (Identifying risks)

3. How did this impact your operations? (Assessing)

4. What did you do about it? (Mitigating)

5. Which risks do you expect to encounter in the future? (Improving) The results showed that Indian supply chains are most severely affected by the chronic risks of inadequate infrastructure, supplier and labor problems, and stifling 
bureaucracy. We broke the infrastructure risks into three categories - transportation, logistics, and utilities - and although all three came out as highly ranked problems, transportation infrastructure was deemed the worst. Potential disruptions that we read about in the press, such as natural disasters, terrorism and crime, were not ranked as that severe by our sample of managers. Dramatic episodes and disasters may individually cause a major impact, but the daily grind of poor infrastructure, labor/ supplier problems and bureaucracy is what relentlessly takes up management time and chips away at a company's bottom line.

We learned that certain categories of firms are exposed to different degrees of severity when it comes to particular disruptions. For example, Indian owned companies reported greater severity (defined as frequency times impact) in the areas of supplier problems, bureaucracy/red tape and inadequate utilities infrastructure. Smaller companies (in terms of global sales) reported significantly more severe disruptions overall, and specifically in the categories of supplier problems, logistics infrastructure, and bureaucracy/red tape. Service companies seemed more affected by logistics and utilities infrastructure risks. Is it possible that foreign owned and/or large firms and/or manufacturers possess greater resources and perhaps better supply chain talent to properly manage and fend off these problems? Without more research and investigation, we just don't know yet what the underlying causes of these disruptions are, and why certain categories of companies are more exposed.

As for useful and appropriate risk mitigation methods, our sample ranked buffering and redundancies on top for problems related to suppliers, labor and 
infrastructure. For bureaucracy, flexibility and visibility/collaboration were found to be the most useful. Comments from respondents and other industry experts indicated that the traditional supply chain mitigation methods (buffering, redundancies, flexibility, visibility/collaboration) were not sufficient to lessen many of the risks experienced in India. Keeping extra inventories helps little to alleviate corruption, the remnants of the "permit Raj" and various tax challenges.

The knowledge that most of the serious supply chain risks are either infrastructure related or internal to the supply chain (supplier and labor problems) should help companies in prioritizing their efforts and organizational practices. A silver lining is that such problems are partially fixable through competent management practices. Resilient companies gradually learn how to successfully navigate the challenging Indian business environment. This takes resources in the form of superb managers, robust information systems, and strong internal routines for how to handle and dissipate disruptions.

Future research should attempt to further dissect the nature of the individual disruptions. As we suggested, a qualitative study of the supplier and labor problems would be very valuable in uncovering subcategories, root causes and the intertwined nature of these serious risks. A qualitative or case based approach will enable researchers to analyze individual instances of disruptions and limited to specific sectors of the Indian economy. The financial impact of disruptions should also be explored further. It would moreover be valuable to investigate which mitigation methods work best to tackle India's non-physical supply chain impediments, such as the regulatory 
conditions, corruption/bribery, and the complex and opaque interstate tax regimes. The purpose of all of this research is to make managers better prepared and to suggest realistic venues for policy makers. 


\section{REFERENCES}

Aliahmadi, A. R., Jafari, M., \& Amiri, B. (2006). Management of risks in supply chain projects. Paper presented at the 2nd National Conference on Logistics \& Supply Chain, Iran. http://www.civilica.com/EnPaper-NCLSCO2-NCLSC02 019.html

Andersson, D., \& Norrman, A. (2004). Outsourcing advanced logistics: A shipper's and provider's perspective on risks. In C. Brindley (Ed.), Supply Chain Risk. Aldershot, UK: Ashgate Publishing Company.

APCAC. (2011). U.S. Trade With the Asia-Pacific Region: Recommendations from the Asia-Pacific Council of American Chambers of Commerce Annual Meeting. Singapore.

Arntzen, B. (2010a). Global Supply Chain Risk Management Part 1: Differences in Attitudes. MIT CTL White Paper. http://ctl.mit.edu/research

Arntzen, B. (2010b). Global Supply Chain Risk Management Part 2: Differences in Frequencies and Priorities. MIT CTL White Paper. http://ctl.mit.edu/research

Arntzen, B. (2010c). Global Supply Chain Risk Management Part 3: Differences in Practices. MIT CTL White Paper. http://ctl.mit.edu/research

Asian_Disaster_Reduction_Center. (2012). Natural Disaster Data Book 2011 (An Analytical Overview). Japan.

Autry, C. W., \& Bobbitt, L. M. (2008). Supply chain security orientation: conceptual development and a proposed framework. The International Journal of Logistics Management, 19(1), 42-64.

Aydin, G., Babich, V., Beil, D., \& Yang, Z. (2012). Decentralized Supply Risk Management. In P. Kouvelis, L. Dong, O. Boyabatli \& R. Li (Eds.), The Handbook of Integrated Risk Management in Global Supply Chains. Hoboken, NJ: John Wiley \& Sons, Inc.

Baird, B. F. (1989). Managerial Decisions under Uncertainty: An introduction to the analysis of decision making. New York, NY: John Wiley \& Sons, Inc.

Bakshi, N., \& Kleindorfer, P. R. (2009). Co-opetition and Investment for Supply-Chain Resilience. Production and Operations Management, 18(6), 583-603.

Ball, B. (2012). CSCO View of Resilient Supply Chains Analyst Insight.

Banker, S. (2009). 'Power Curves' and Supply Chain Risk Management. Logistics Viewpoints. http://logisticsviewpoints.com/2009/06/15

Barboza, D., \& Bradsher, K. (2012, Sept. 25, 2012). Factory Riot Underscores Rift in China, The New York Times.

Barratt, M., \& Oke, A. (2007). Antecedents of supply chain visibility in retail supply chains: A resource-based theory perspective. Journal of Operations Management, 25, 1217-1233.

Barry, J. (2004). Supply chain risk in am uncertain global supply chain environment. International Journal of Physical Distribution \& Logistics Management, 34(9), 695-697.

Bhatia, G., Lane, C., \& Wain, A. (2013). Building Resilience in Supply Chains. http://www.accenture.com/SiteCollectionDocuments/PDF/Accenture-BuildingResilience-Supply-Chains.pdf

Blackhurst, J., Craighead, C. W., Elkins, D., \& Handfield, R. B. (2005). An empirically derived agenda of critical research issues for managing supply-chain disruptions. International Journal of Production Research, 43(19), 4067-4081.

Blackhurst, J., Dunn, K. S., \& Craighead, C. W. (2011). An Empirically Derived Framework of Global Supply Resiliency. Journal of Business Logistics, 32(4), 374-391. 
Bode, C., Wagner, S. M., Petersen, K. J., \& Ellram, L. M. (2011). Understanding Responses to Supply Chain Disruptions: Insights from Information Processing and Resource Dependence Perspectives. Academy of Management Journal, 54(4), 833-856.

Bosman, R. (2006). The new supply chain challenge: Risk management in a global economy: FM Global.

Bowser, R., \& Balasubramaniam, K. (2009). In Search of Supply Chain Excellence. http://www.cognizant.com/InsightsCognizantiarticles/Cognizanti In-Search-ofExcellence Supply\%20Chain.pdf

Bradsher, K. (2012, May 8, 2012). Chinese Exporters' Weakness at Fair Points to Broader Economic Anxiety, The New York Times.

Braun, M. (2012). Supply Chain Risk Management: Developing the Roadmap. Powerpoint presentation to Massachusetts RIMS, March 2012: FM Global Business Risk Consulting.

Braunscheidel, M. J., \& Suresh, N. C. (2009). The organizational antecedents of a firm's supply chain agility for risk mitigation and response. Journal of Operations Management, 27, 119-140.

Brindley, C. (Ed.). (2004). Supply Chain Risk. Aldershot, England: Ashgate Publishing Company.

Burges, D. (2011). FreightWatch International Global Threat Assessment. http://www.transportschaden.biz/html/documents/FreightWatch Global Threat Asses sment 2011.pdf

Burges, D. (2012). FreightWatch International Global Threat Assessment: Global Cargo Theft Risk. Distribution Business Management Journal, 14, 59-62.

Burt, D., Petcavage, S., \& Pinkerton, R. (2010). Supply Management (8th ed.). New York, NY: McGraw-Hill.

Canbolat, Y. B., Gupta, G., Matera, S., \& Chelst, K. (2008). Analysing risk in sourcing design and manufacture of components and sub-systems to emerging markets. International Journal of Production Research, 46(18), 5145-5164.

Carter, C. R., \& Rogers, D. S. (2008). A framework of sustainable supply chain management: moving toward new theory. International Journal of Physical Distribution \& Logistics Management, 38(5), 360-387.

CAS. (2007). CAS Enterprise Risk Management (ERM) Vision (4/2/07). http://www.casact.org/area/erm/CASERMVision.pdf

Cavinato, J. L. (2004). Supply chain logistics risks: From the back room to the board room. International Journal of Physical Distribution \& Logistics Management, 34(5), 383-387.

Cavusgil, S. T., Knight, G., \& Riesenberger, J. R. (2008a). International Business: Strategy, Management, and the New Realities. Upper Saddle River, NJ: Pearson Prentice Hall.

Cavusgil, S. T., Knight, G., \& Riesenberger, J. R. (2011). International Business: The New Realities (2nd ed.). Upper Saddle River, NJ Prentice Hall.

Cavusgil, S. T., Knight, G., \& Riesenberger, J. S. (2008b). International Business: Strategy, management, and the new realities. Upper Saddle River, NJ: Pearson Prentice Hall.

Central_Intelligence_Agency. (2012). The CIA World Factbook 2012. New York, NY: Skyhorse Publishing, Inc.

Chapman, P., Christopher, M., Jüttner, U., Peck, H., \& Wilding, R. (2002). Identifying and Managing Supply-Chain Vulnerability. Logistics and Transport Focus, 4(4), 59-64.

Chopra, S., Reinhardt, G., \& Mohan, U. (2007). The importance of decoupling recurrent and disruption risks in a supply chain. Naval Research Logistics (NRL), 54(5), 544-555.

Chopra, S., \& Sodhi, M. S. (2004). Managing Risk to Avoid Supply-Chain Breakdown. MIT Sloan Management Review, Fall 2004, 53-61. 
Christensen, C. M. (2003). The Innovator's Dilemma. New York, NY: HarperCollins Publishers Inc. Christopher, M. (2002). Supply Chain Vulnerability: Executive Report: Cranfield University School of Management.

Christopher, M., \& Lee, H. (2004). Mitigating supply chain risk through improved confidence. International Journal of Physical Distribution \& Logistics Management, 34(5), 388-396.

Christopher, M., Mena, C., Khan, O., \& Yurt, O. (2011). Approaches to managing global sourcing risk. Supply Chain Management: An International Journal, 16(2), 67-81.

Christopher, M., \& Peck, H. (2004). Building the resilient supply chain. The International Journal of Logistics Management, 15(2), 1-13.

CIA, C. I. A. (2012). The CIA World Factbook 2012. New York, NY: Skyhorse Publishing, Inc.

Cleland, D. I., \& Kocaoglu, D. F. (1981). Engineering Management. New York: McGraw-Hill.

Closs, D. J., \& McGarrell, E. F. (2004). Enhancing Security Throughout the Supply Chain Special Report Series: Michigan State University.

Cohen, M. A., \& Kunreuther, H. (2007). Operations risk management: Overview of Paul Kleindorfer's contributions. Production and Operations Management, 16(5), 525-541.

Coleman, L. (2006). Frequency of Man-Made Disasters in the 20th Century. Journal of Contingencies and Crisis Management, 14(1), 3-11.

Commercial_Service, U. S. (2012). Doing Business in India: 2012 Country Commercial Guide for U.S. Companies. Delhi.

Coyle, J. C., Novack, R. A., Gibson, B. J., \& Bardi, E. J. (2011). Transportation: A Supply Chain Perspective (7th ed.). Mason, $\mathrm{OH}$ : South-Western Cengage Learning.

Coyle, J. J., Langley, C. J. J., Novack, R. A., \& Gibson, B. J. (2013). Supply Chain Management: A Logistics Perspective (9th edition ed.). Mason, OH: South-Western Cengage Learning.

Craighead, C. W., Blackhurst, J., Rungtusanatham, M. J., \& Handfield, R. B. (2007). The severity of supply chain disruptions: design characteristics and mitigation capabilities. Decision Sciences, 38(1), 131-156.

Crone, M. (2006). Are global supply chains too risky? A practitioner's perspective. . Supply Chain Management Review, 10(4), 28-35.

Cullen, J. B., \& Parboteeah, K. P. (2008). Multinational Management: A Strategic Approach. Mason, $\mathrm{OH}$ : Thomson South-Western.

de_Koster, R. B. M., Stam, D., \& Balk, B. M. (2011). Accidents happen: The influence of safetyspecific transformational leadership, safety consciousness, and hazard reducing systems on warehouse accidents. Journal of Operations Management, 29, 753-765.

Denning, P. J., \& Bell, T. (2012). The Information Paradox. American Scientist, 100(6), 470-477.

Deresky, H. (2008). International Management: Managing Across Borders and Cultures (6th ed.). Upper Saddle River, NJ: Pearson Prentice Hall.

Dow_Chemicals. (2012). Risk Management at Dow. Paper presented at the CSCMP India 2012 Conference, Mumbai. http://cscmp.org/events/india/proceedings/presentation3.pdf

Dunn, A. G. (2011). Managing risks in your global supply chain [Power Point Presentation to Institute of Management Accountants, Tacoma, WA]: GDI Consulting \& Training Company.

Dutton, G. (2013). Is Your Supply Chain Safe? World Trade 100, January 2013, 35-40.

Economist, T. (2012a). Aim Higher: Special Report India. The Economist Magazine.

Economist, T. (2012b, Nov. 8, 2012). The World in 2013. The Economist.

Economist, T. (2013a). Wasting Time: India will soon have a fifth of the world's working-age population. It urgently needs to provide them with better jobs. The Economist, 23-26.

Economist, T. (2013b, December, 2013). The World in 2014. The Economist. 
Elkins, D., Handfield, R. B., Blackhurst, J., \& Craighead, C. W. (2005). 18 Ways to Guard Against Disruption. Supply Chain Management Review, 9(1), 46-53.

Ellinger, A. E., Keller, S. B., \& Hansen, J. D. (2006). Bridging the divide between logistics and marketing: Facilitating collaborative behavior. Journal of Business Logistics, 27(2), 1-27.

Ellis, S. C., Henry, R. M., \& Shockley, J. (2010). Buyer perceptions of supply disruption risk: A behavioral view and empirical assessment. Journal of Operations Management, 28, 3446.

Ellram, L. M., Tate, W. L., \& Billington, C. (2006). Understanding and managing the services supply chain. Journal of Supply Chain Management, 40(4), 17-32.

EM-DAT. (2012). The OFDA/CRED International Disaster Database. Brussels, Belgium: Universite Catholique de Louvain.

Engardio, P. (2007). Chindia: How China and India Are Revolutionizing Global Business. New York. NY: McGraw-Hill.

Enslow, B. (2008). Stemming the rising tide of supply chain risks: How risk managers' roles and responsibilities are changing.

Enyinda, C. I., Ogbuehi, A., \& Briggs, C. (2008). Global supply chain risk management: A new battleground for gaining competitive advantage. Paper presented at the 15th Annual Conference, Las Vegas.

Eule, A. (2012, Nov. 26, 2012). Equanimity and Equities. Barron's.

Faisal, M. N., Banwet, D., \& Shankar, R. (2006). Mapping supply chains on risk and customer sensitivity dimensions. Industrial Management \& Data Systems, 106(6), 878-895.

Faisal, M. N., Banwet, D., \& Shankar, R. (2007). Supply chain risk management in SMEs: analysing the barriers. International Journal of Management and Enterprise Development, 4(5), 588-607.

Faisal, M. N., Banwet, D. K., \& Shankar, R. (2006). Supply chain risk mitigation: modeling the enablers. Business Process Management Journal, 12(4), 535-552.

Favre, D., \& McCreery, J. (2008). Coming to grips with supplier risk. Supply Chain Management Review(September 2008), 26-32.

Ferrer, J., Hintlian, J., \& Karlberg, J. (2007). Integration: the key to global success. Supply Chain Management Review, 11(March, 2007).

Finch, P. (2004). Supply chain risk management. Supply Chain Managenent: An International Journal, 9(2), 183-196.

Fitzgerald, K. R. (2005). Big savings, but lots of risk: low-cost country sourcing (LCCS) promises big benefits. But before they adopt a LCCS strategy, companies need to understand the related risks and how to mitigate them Supply Chain Management Review, 16(Dec. 2005).

Folkard, C. (2003). Guinness World Records 2003. London, UK: Guinness World Records Ltd.

Fowler, F. J. (1995). Improving Survey Questions: Design and Evaluation. Thousand Oaks, CA: Sage Publications.

Fox_News. (2011). E. Coli Outbreak Likely Caused by Bean Sprouts. Fox News. http://www.foxnews.com/health/2011/06/05/e-coli-outbreak-overwhelms-germanhospitals/print\#

Frankel, R., Bolumole, Y. A., Eltantawy, R. A., Paulraj, A., \& Gundlach, G. T. (2008). The domain and scope of SCM's foundational disciplines - Insights and issues to advance research. Journal of Business Logistics, 29(1), 1-20.

Germain, R., \& lyer, K. N. S. (2006). The interaction of internal and downstream integration and its association with performance. Journal of Business Logistics, 27(2), 29-52. 
Ghadge, A., Dani, S., \& Kalawsky, R. (2011). Supply chain risk management: An analysis of present and future scope. Paper presented at the 16th International Symposium on Logistics (ISL 2011), Berlin.

Gilmore, D. (2009). The Top Supply Chain Disasters of All Time. SupplyChainDigest. www.scdigest.com

Gitman, L. J., \& McDaniel, C. (2009). The Future of Business: The Essentials (4th ed.). Mason, OH: South-Western Cengage Learning.

Giunipero, L. C., \& Eltantawy, R. A. (2004). Securing the upstream supply chain: a risk management approach. International Journal of Physical Distribution \& Logistics Management, 34(9), 698-713.

Glendon, L. (2012). Supply Chain Resilience 2012: 4th Annual Survey. www.thebci.org

Global_Integrity. (2012). India Notebook 2011 \& India Timeline 2011. Global Integrity Report. www.globalintegrity.org/report/India/2011/

Goldratt, E. M. (1992). The Goal: A process of ongoing improvement (2nd Revised ed.). Great Barrington, MA: The North River Press Publishing Corp.

Grant, R. M. (2002). The resource-based theory of competitive advantage: Implications for strategy formulation. In D. Faulkner (Ed.), Critical Perspectives on Business and Management (pp. 135-157). London: Routledge.

Gray, J. V., Roth, A. V., \& Leiblein, M. J. (2011). Quality risk in offshore manufacturing: Evidence from the pharmaceutical industry. Journal of Operations Management, 29, 737-752.

Groves, R. M., Fowler, F. J., Couper, M. P., Lepkowski, J. M., Singer, E., \& Tourangeau, R. (2009). Survey Methodology. Hoboken, NJ: John Wiley \& Sons, Inc.

Gualandris, J., \& Kalchschmidt, M. (2011). The impact of risk conditions and postponement on upstream supply chain vulnerability. Paper presented at the POMS 22nd Annual Conference, Reno, NV.

Guardian_The. (2010). Climate change threatens emerging superpowers, warns report. The Guardian. www.guardian.co.uk

Guha-Sapir, D., Vos, F., Below, R., \& Ponserre, S. (2012). Annual Disaster Statistical Review 201: The numbers and trends. Brussels: Centre for Research on the Epidemiology of Disasters (CRED).

Haksöz, Ç., \& Arslan, Ö. (2012). Enerjisa: Managing procurement risks in the Turkish energy industry. In O. Khan \& G. A. Zsidisin (Eds.), Handbook for Supply Chain Risk Management (pp. 125-135). Ft. Lauderdale, FL: J. Ross Publishing, Inc.

Hale, T., \& Moberg, C. R. (2005). Improving supply chain disaster preparedness: A decision process for secure site location. International Journal of Physical Distribution \& Logistics Management, 35(3), 195-207.

Hallikas, J., Puumalainen, K., Vesterinen, T., \& Virolainen, V.-M. (2005). Risk-based classification of supplier relationships. Journal of Purchasing \& Supply Management, 11(2/3), 72-82.

Hammer, M. (2001). The Superefficient company. Harvard Business Review(Sept. 2001), 82-91.

Handfield, R. (2007). Reducing the impact of disruptions to the supply chain. Sascom magazine. http://www.sas.com/resources/asset/sascom.pdf

Harland, C., Brenchley, R., \& Walker, H. (2003). Risk in supply networks. Journal of Purchasing \& Supply Management, 9, 51-62.

Heal, G., Kearns, M., Kleindorfer, P., \& Kunreuther, H. (2006). Interdependent security in interconnected networks Seeds of disaster, roots of response: How private action can reduce public vulnerability.

Heaney, B. (2012). Supply Chain Visibility Excellence: Mastering Complexity and Landed Costs. 
Hendricks, K. B., \& Singhal, V. R. (2003). The effect of supply chain glitches on shareholder wealth. Journal of Operations Management, 21(5), 501-522.

Hendricks, K. B., \& Singhal, V. R. (2005a). Association Between Supply Chain Glitches and Operating Performance. Management Science, 51(5), 695-711.

Hendricks, K. B., \& Singhal, V. R. (2005b). An Empirical Analysis of the Effect of Supply Chain Disruptions on Long-Run Stock Price Performance and Equity Risk of the Firm. Production and Operations Management, 14(1), 35-52.

Hendricks, K. B., \& Singhal, V. R. (2012). Supply Chain Disruptions and Corporate Performance. In H. Gurnani, A. Mehrotra \& S. Ray (Eds.), Supply Chain Disruptions: Theory and Practice of Managing Risk. London: Springer Verlag London Ltd.

Hendricks, K. B., Singhal, V. R., \& Zhang, R. (2009). The effect of operational slack, diversification, and vertical relatedness on the stock market reaction to supply chain disruptions. Journal of Operations Management, 27, 233-246.

Heritage_Foundation. (2012). 2012 Index of Economic Freedom. http://www.heritage.org/index/country/india

Holton, G. A. (2004). Defining Risk. Financial Analysts Journal, 60(6), 19-25.

Hoskisson, R. E., Eden, L., Lau, C. M., \& Wright, M. (2000). Strategy in Emerging Economies. Academy of Management Journal, 43(3), 249-267.

Humanity, V. o. (2013). Global Terrorism Index. from http://www.visionofhumanity.org/globalterrorismindex/\#/2011/OVER/

Humphrey, J. (2003). Globalization and supply chain networks: the auto industry in Brazil and India. Global Networks, 3(2), 121-141. doi: 10.1111/1471-0374.00053

lakovou, E., Vlachos, D., \& Xanthopoulos, A. (2009). Risk and Security Management for Logistics Service Providers: Trends, Challenges, and Opportunities. In S. Wagner \& C. Bode (Eds.), Managing Risk and Security. Berne: Haupt Publisher.

IFEP. (2012). Global Terrorism Index: Capturing the Impact of Terrorism from 2002 - 2011. www.visionofhumanity.org

IHS. (2012). Comprehensive Supplier Risk Modeling. IHS Supplier Risk White Paper. www.ihs.com/SupplierRisk

ISO. (2011). ISO 28002:2011 - Security management systems for the supply chain - Development of resilience in the supply chain - Requirements with guidance for use. In International_Organization_for_Standardization (Ed.). Geneva.

Jiang, B., Baker, R. C., \& Frazier, G. V. (2009). An analysis of job dissatisfaction and turnover to reduce global suppy chain risk: Evidence from China. Journal of Operations Management, 27, 169-184.

Johnson, B. (2012). Creating Value Through Supply Chain Risk Management. Supply Chain Brain. Johnson, L. A. (2012, Dec. 3, 2012). Generic Lipitor from India recalled, The Associated Press. Jüttner, U. (2005). Supply chain risk management: Understanding the business requirements from a practitioner perspective. The International Journal of Logistics Management, 16(1), 120-141.

Jüttner, U., \& Maklan, S. (2011). Supply chain resilience in the global financial crisis: an empirical study. Supply Chain Managenent: An International Journal, 16(4), 246-259.

Jüttner, U., Peck, H., \& Christopher, M. (2003). Supply chain risk management: Outlining an agenda for future research. International Journal of Logistics Research and Applications, 6(4), 197-210.

Kaplan, S., \& Garrick, B. J. (1981). On the Quantitative Definition of Risk. Risk Analysis, 1(1), 1127. 
Kearney, A. T. (2013). Foreign Direct Confidence Index Top 25. Retrieved Nov. 4, 2013, from www.atkearney.com/research-studies/foreign-direct-investment-confidence-index

Kelly, J. V. (2011). Four Steps to Improved Supplier Risk Management. Supply \& Demand Chain Executive Magazine. www.sdcexec.com

Kern, D., Moser, R., Hartmann, E., \& Moder, M. (2012). Supply risk management: model development and empirical analysis. International Journal of Physical Distribution \& Logistics Management, 42(1), 60-82.

Kessinger, C., \& McMorrow, J. (2012). Supply Chain Risk Management: A Perspective from Practice. In P. Kouvelis, L. Dong, O. Boyabatli \& R. Li (Eds.), The Handbook of Integrated Risk Management in Global Supply Chains. Hoboken, NJ: John Wiley \& Sons, Inc.

Khan, O., \& Zsidisin, G. A. (2012). Handbook for Supply Chain Risk Management: Case Studies, Effective Practices and Emerging Trends. Ft. Lauderdale, FL: J. Ross Publishing, Inc.

Khan, S. (2012). India Notebook 2011: Architects of an Evil Design. Global Integrity Report. www.globalintegrity.org/report/India/2011/notebook

Kinder, A. (2008). Mitigating Risk Through Best Practices. Supply \& Demand Chain Executive Magazine. www.sdcexec.com

KKR. (2012). India: Unlocking the Demographic Dividend. Insights: Globasl Macro Trends, 2.10.

Kleindorfer, P. R., \& Saad, G. H. (2005). Managing disruption risk in supply chains. Production and Operations Management, 14(1), 53-68.

Kleindorfer, P. R., \& Van Wassenhove, L. N. (2004). Managing Risk in Global Supply Chains. In H. Gatigon \& J. Kimberly (Eds.), The Alliance on Globalization: Cambridge University Press.

Klir, G. J. (2001). Facets of Systems Science (2nd ed.). New York: Kluwer Academic/Plenum Publishers.

Knemeyer, A. M., Zinn, W., \& Eroglu, C. (2009). Proactive planning for catastrophic events in supply chains. Journal of Operations Management, 27, 141-153.

Kocabasoglu, C., Prahinski, C., \& Klassen, R. D. (2007). Linking forward and reverse supply chain investments: The role of business uncertainty. Journal of Operations Management, 25, 1141-1160.

Kotabe, M., \& Murray, J. Y. (2004). Global sourcing strategy and sustainable competitive advantage. Industrial Marketing Management, 33(1), 7-14.

Kouvelis, P., Chambers, C., \& Wang, H. (2006). Supply Chain Management Research and Production and Operations Management: Review, Trends, and Opportunities. Production and Operations Management, 15(3), 449-469.

Kouvelis, P., Dong, L., Boyabatli, O., \& Li, R. (Eds.). (2012). The Handbook of Integrated Risk Management in Global Supply Chains. Hoboken, NJ: John Wiley \& Sons Inc.

Kumar, R., \& Sethi, A. K. (2005). Doing Business in India. New York, NY: Palgrave MacMillan.

Laeequddin, M., Sardana, G., Sahay, B., Waheed, K. A., \& Sahay, V. (2009). Supply chain partners' trust building process through risk evaluation: the perspectives of UAE packaged food industry. Supply Chain Management: An International Journal, 14(4), 280-290.

Lai, K.-h., Ngai, E. W. T., \& Cheng, T. C. E. (2002). Measures for Evaluating Supply Chain Performance in Transport Logistics. Transportation Research Part E: Logistics and Transportation Review, 38(6), 439-456.

Laios, L., \& Moschuris, S. (1999). An Empirical Investigation of Outsourcing Decisions. The Journal of Supply Chain Management, 35(1), 33-41.

Lakshmi, R. (2010, Oct. 2, 2010). On eve of Commonwealth Games, India's persistent red tape is in spotlight, The Washington Post. 
Lambert, D. M., \& Cooper, M. C. (2000). Issues in Supply Chain Management. Industrial Marketing Management, 29, 65-83.

Lavastre, O., Gunasekaran, A., \& Spalanzani, A. (2012). Supply chain risk management in French companies. Decision Support Systems, 52, 828-838.

Lavelle, M., Smith, J., \& Byerly, R. (2012). India Power Outage Spotlights Energy Planning Failure. National Geographic Daily News.

http://news.nationalgeographic.com/news/energy/2012/07/120731-india-poweroutage-analysis/

Lee, H. L. (2002). Aligning Supply Chain Strategies with Product Uncertainties. California Management Review, 44(3), 105-119.

Lee, H. L. (2004). The Triple-A Supply Chain. Harvard Business Review, 82(10), 102-112.

Lee, H. L., So, K. C., \& Tang, C. S. (2000). The value of information sharing in a two-level supply chain. Management Science, 46(5), 626-643.

Lee, H. L., \& Whang, S. (2005). Higher supply chain security with lower cost: Lessons from total quality management. International Journal of Production Economics, 96, 289-300.

Levary, R. R. (2007). Ranking foreign suppliers based on supply risk. Supply Chain Management: An International Journal, 12(6), 392-394.

Lonsdale, C. (1999). Effectively managing vertical supply relationships: a risk management model for outsourcing. Supply Chain Management: An International Journal, 4(4), 176-183.

Madhavan, K., Doshi, S., Chandra, N., \& Pansari, M. (2013). Creating Competitive Advantage Through Supply Chain: India Insights. A.T. Kearney study for CSCMP India, February 2013. Mumbai: A.T. Kearney Ltd.

Mahendran, H., Narasimhan, K., Nagarajan, N., \& S, G. (2011, July 6-8, 2011). Investigation of Supply Chain Risk in the Indian Pharmaceutical Industry: A Case Study. Paper presented at the World Congress on Engineering 2011, London, UK.

Makar, E. M. (2008). An American's Guide to Doing Business in India: A Practical Guide to Achieving Success in the Indian Market. Avon, MA: Adams Business.

Mangan, J., Lalwani, C., \& Butcher, T. (2008). Global Logistics and Supply Chain Management. Chichester, UK: John Wiley \& Sons, Ltd.

Manuj, I., \& Mentzer, J. T. (2008a). Global Supply Chain Risk Management. Journal of Business Logistics, 29(1), 133-155.

Manuj, I., \& Mentzer, J. T. (2008b). Global supply chain risk management strategies. International Journal of Physical Distribution \& Logistics Management, 38(3), 192-223.

Maplecroft. (2012a). Economies of Bangladesh, Philippines, Myanmar, India, Viet Nam at highest risk from natural hazards - Risk Atlas. www.maplecroft.com

Maplecroft. (2012b). Natural Hazards Risk Atlas. Retrieved Jan. 7, 2014, from http://maplecroft.com/about/news/nha 2012.html

MapsOfIndia.com (Cartographer). (2012). India Flood Prone Areas. Retrieved from http://www.mapsofindia.com/top-ten/geography/india-flood.html

Marantis, D. (2013). 2013 Special 301 Report. Washington DC: Office of the United States Trade Representative.

March, J. G., \& Shapira, Z. (1987). Managerial Perspectives on Risk and Risk Taking. Management Science, 33(11), 1404-1418.

Markmann, C., Gnatzy, T., von der Gracht, H. A., \& Darkow, I.-L. (2011). Supply chain security 2030 - How security issues will affect global supply chains. Paper presented at the 16 th International Symposium on Logistics (ISL 2011), Berlin.

Markowitz, H. (1952). Portfolio Selection. Journal of Finance, 7(1), 77-91. 
Martin, J. W. (2007). Lean Six Sigma for Supply Chain Management: The 10-step solution process. New York: McGraw Hill.

Marucheck, A., Greis, N., Mena, C., \& Cai, L. (2011). Product safety and security in the global supply chain: Issues, challenges and research opportunities. Journal of Operations Management, 29, 707-720.

Matook, S., Lasch, R., \& Tamaschke, R. (2009). Supplier development with benchmarking as part of a comprehensive supplier risk management framework. International Journal of Operations \& Production Management, 29(3), 241-267.

McClory, C. (2012). De-Risking the Supply Chain. Spend Matters, (June 19, 2012). http://www.spendmatters.com/index.cfm/2012/6/19/DeRisking-the-Supply-Chain

McCormack, K., Wilkerson, T., Marrow, D., Davey, M., Shah, M., \& Yee, D. (2008). Managing risk in your organization with the SCOR methodology.

McKinsey, C. (2013). Reimagining India (C. Chandleer \& A. Zainulbhai Eds.). New York, NY: Simon \& Schuster.

Melnyk, S. A., Ragatz, G. L., \& Zsidisin, G. A. (2005). The dark side of supply chain management. Supply Chain Management Review, 9(2), 46-52.

Merriam-Webster, A. (Ed.) (1976). Springfield, MA: G. \& C. Merriam Company.

Miller, K. D. (1992). A framework for integrated risk management in international business. Journal of International Business Studies, 23(2), 311-331.

Mitchell, M. (2009). Complexity: a guided tour. New York: Oxford University Press.

Mitchell, V.-W. (1995). Organizational Risk Perception and Reduction: A Literature Review. British Journal of Management, 6(2), 115-133.

Moberg, C. R., Cutler, B. D., Gross, A., \& Speh, T. W. (2002). Indentifying antecedents of information exchange within supply chains. International Journal of Physical Distribution \& Logistics Management, 32(9), 755-770.

Monroe, R. W., Teets, J. M., \& Martin, P. R. (2012). Supply chain risk management: An analysis of sources of risk in the literature.

Mullai, A. (2004). A Risk Analysis Framework for Marine Transport of Packaged Dangerous Goods. In C. Brindley (Ed.), Supply Chain Risk. Aldershot, UK: Ashgate Publishing Ltd.

Muthukrishnan, R., \& Shulman, J. A. (2006). Understanding supply chain risk: A McKinsey Global Survey. McKinsey Quarterly. www.mckinseyquarterly.com/article print.aspx?L2=1\&L3=26\&ar=1847

Nandgaonkar, S., \& Sebastian, X. (2012). Thriving in a Volatile World: Conversations with Leaders.

http://www.cii.in/PublicationDetail.aspx?enc=/wZUwSs+pu/ty+v2V02LLFjRxB+GsDTOuj qvbGmOiZRysiBpelNfGwtU65z8f3gdpAnkKS57r8yyErmtIRW+veDA1qkRqgPeieB8OplG3K Nfiv1mt8aqZ00kPndhlrWDQLumDrs7ihkStHclkcwE7g==

NBC. (2012). Toyota to hold world's biggest car recall in 16 years. NBC News Wire Services. http://www.nbcnews.com/business/toyota-hold-worlds-biggest-car-recall-16-years$1 \mathrm{C6374378}$

Neufville, R. d. (2003). Real Options: Dealing with Uncertainty in Systems Planning and Design. Integrated Assessment, 4(1), 26-34.

Nguyen, H. V. (2011). Risk and Visibility in Global Supply Chains: An Empirical Study. (Ph.D. Ph.D. dissertation), Georgia State University.

Nicholls, R. J. (2008). The Exposure of Port Cities to Flooding: A Comparative Global Analysis. http://www.oecd-ilibrary.org/environment/ranking-port-cities-with-high-exposure-andvulnerability-to-climate-extremes 011766488208 
Nohria, N. (2006). Risk, Uncertainty, and Doubt. Harvard Business Review, 84(2), 39-40.

Norrman, A. (2008). Supply chain risk-sharing contracts from a buyer's perspective: content and experiences. International Journal of Procurement Management, 1(4), 371-393.

Norrman, A., \& Jansson, U. (2004). Ericsson's proactive supply chain risk management approach after a serious sub-supplier accident. International Journal of Physical Distribution \& Logistics Management, 34(5), 434-456.

Norrman, A., \& Lindroth, R. (2004). Categorization of Supply Chain Risk and Risk Management. In C. Brindley (Ed.), Supply Chain Risk. Aldershot, UK: Ashgate Publishing Co.

Oehmen, J. P. H. (2009). Managing Supply Chain Risks: The Example of Successful Sourcing from China. (Doctor of Sciences Dissertation), ETH Zurich.

Oke, A., \& Gopalakrishnan, M. (2009). Managing disruptions in supply chains: A case study of a retail supply chain. International Journal of Production Economics, 118, 168-174.

Olson, D. L. (2012). Supply Chain Risk Management: Tools for Analysis. New York, NY: Business Expert Press LLC.

Olson, D. L., \& Wu, D. (2010). Enterprise risk management models. Berlin: Springer Verlag.

Oshri, I., Kotlarsky, J., \& Willcocks, L. P. (2011). The Handbook of Global Outsourcing and Offshoring (2nd ed.). U.K.: Palgrave Macmillan.

Panagariya, A. (2008, Nov. 29, 2008). The Economic Cost of the Mumbai Tragedy. Forbes.

Paulsson, U. (2005, June 9-10, 2005). Developing a supply chain flow risk model. Paper presented at the NOFOMA 2005 Conference, Copenhagen.

Peck, H. (2005). Drivers of supply chain vulnerability: an integrated framework. International Journal of Physical Distribution \& Logistics Management, 35(4), 210-232.

Peck, H. (2009). Supply Chain Risk \& Business Continuity [Power point presentation]: Cranfield University, College of Management \& Tehnology.

Perrow, C. (1999a). Normal Accidents: Living with High Risk Technologies. Princeton, NJ: Princeton University Press.

Perrow, C. (1999b). Organizing to Reduce the Vulnerabilities of Complexity. Journal of Contingencies and Crisis Management, 7(3), 150-155.

Perry, M. (2007). Natural disaster management planning: A study of logistics managers responding to the tsunami. International Journal of Physical Distribution \& Logistics Management, 37(5), 409-433.

Pettit, T. J., Fiksel, J., \& Croxton, K. L. (2010). Ensuring supply chain resilience: Development of a conceptual framework. Journal of Business Logistics, 31(1), 1-21.

Ponomarov, S. Y., \& Holcomb, M. C. (2009). Understanding the concept of supply chain resilience. The International Journal of Logistics Management, 20(1), 124-143.

Prakash, A. (2011). Why volatility matters. In A. Prakash (Ed.), Safeguarding Food Security in Volatile Global Markets (pp. 3-26): FAO.

Pyke, D., \& Tang, C. S. (2010). How to mitigate product safety risks proactively? Process, challenges and opportunities. International Journal of Logistics Research and Applications, 13(4), 243-256.

Rahman, Z. (2004). Use of internet in supply chain management: a study of Indian companies. Industrial Management \& Data Systems, 104(1), 31-41.

Ramsey, M., \& Moffett, S. (2011, March 23, 2011). Japan Parts Shortage Hits Auto Makers, The Wall Street Journal.

Rao, S., \& Goldsby, T. J. (2009). Supply chain risks: a review and typology. The International Journal of Logistics Management, 20(1), 97-123. 
Rein, S. (2012). The End of Cheap China: Economic and Cultural Trends that will Disrupt the World. Hoboken, NJ: John Wiley \& Sons, Inc.

Rice, J. B., \& Caniato, F. (2003). Building a secure and resilient supply network. Supply Chain Management Review(September/October), 22-30.

Richey Jr., R. G., Roath, A. S., Whipple, J. M., \& Fawcett, S. E. (2010). Exploring a governance theory of supply chain management: Barriers and facilitators to integration. Journal of Business Logistics, 31(1), 237-256.

Ritchie, B., \& Brindley, C. (2007). An Emergent Framework for Supply Chain Risk Management and Performance Measurement. The Journal of the Operational Research Society, 58(11), 1398-1400.

Ritter, L., Barrett, J. M., \& Wilson, R. (2007). Securing Global Transportation Networks. New York, NY: McGraw Hill.

Rizzon, E. (2011). Assessment of Excellence in Procurement Survey. Melbourne, Aus.

Robinson, C. H. (2012). Going Global: Building a Sustainable Logistics Model in the Age of Globalization. White Paper. http://www.chrobinson.com/en/us/Resources/WhitePapers/

Royal_Society. (1992). Risk Analysis, Perception and Management. London: Royal Society Publishing.

Sadlovska, V., Spinks, M., \& Shecterle, R. (2008). Supply Chain Risk Management: Building a Resilient Global Supply Chain. http://www.cleartrack.com/content/content/Aberdeen RISK.pdf

Sahay, B. S., Gupta, J. N. D., \& Mohan, R. (2006). Managing supply chains for competitiveness: the Indian scenario. Supply Chain Management: An International Journal, 11(1), 15-24.

Sahay, B. S., \& Mohan, R. (2003). Supply chain management practices in Indian industry. International Journal of Physical Distribution \& Logistics Management, 33(7), 582-606.

Schmitt, A. J., \& Singh, M. (2012). A quantitative analysis of disruption risk in a multi-echelon supply chain. International Journal of Production Economics, 139, 22-32.

ScienceWatch. (2011). Stephan M. Wagner Discusses Supply Chain Risk Management. ScienceWatch.com. http://archive.sciencewatch.com/dr/nhp/2011/11maynhp/11maynhpWagn/

SCRLC. (2011). Supply Chain Risk Management: A Compilation of Best Practices: Supply Chain Risk Leadership Council.

SCRLC. (2012). Supply Chain Risk Leadership Council. www.scrlc.com/about.php

SCRLC. (2013). SCRLC Emerging Risks in the Supply Chain 2013: Supply Chain Risk Leadership Council.

Sen, S. (2012, Nov. 14, 2012). Ease domestic supply chain before FDI, Economic Times.

Senge, P. M. (2006). The Fifth Discipline: The Art and Practice of the Learning Organization (Revised and Updated ed.). New York: Doubleday.

Seuring, S., \& Müller, M. (2008). From a literature review to a conceptual framework for sustainable supply chain management. Journal of cleaner production, 16(15), 16991710.

Shank, G. D. (2006). Qualitative Research: A Personal Skills Approach (2nd ed.). Upper Saddle River, NJ: Pearson Merrill Prentice Hall.

Shavell, S. (1984). A model of the optimal use of liability and safety regulation. Rand Journal of Economics, 15(2), 271-280.

Sheffi, Y. (2005). The Resilient Enterprise: Overcoming Vulnerability for Competitive Advantage (Paperback edition ed.). Cambridge, MA: MIT Press 
Sheffi, Y., \& Rice, J. B. (2005). A supply chain view of the resilient enterprise. MIT Sloan Management Review(Fall 2005), 41-48.

Shister, N. (2011). Small Manufacturers: Can Small part Companies Hang On?

Uncertainty in China. Supply Chain Risk Review, (4th quarter, 2011). www.scrlc.com/newsletter.php

Simchi-Levi, D., Snyder, L., \& Watson, M. (2002). Strategies for Uncertain Times. Supply Chain Management Review(January/February), 11-12.

Singh, K. (2010, Nov. 11, 2010). Pfizer recalls drug from US, Electronic, The Economic Times.

Singh, P. J., Smith, A., \& Sohal, A. S. (2005). Strategic supply chain management issues in the automotive industry: An Australian perspective. International Journal of Production Research, 43(16), 3375-3399.

Singh, S., \& Bindloss, J. (2007). Lonely Planet: India (12th ed.). Victoria, Aus.: Lonely Planet Publications Pty Ltd.

Singhal, P., Agarwal, G., \& Mittal, M. L. (2011). Supply chain risk management: review, classification and future research directions. International Journal of Business Science and Applied Management, 6(3), 15-42.

Sitkin, S. B., \& Pablo, A. L. (1992). Reconceptualizing the determinants of risk behavior. Academy of Management Review, 17(1), 9-38.

Smyrlis, L. (2006). Risky Business: There has been a significant increase in external risks during the past five years and supply chain is the major concern, new survey shows. . Canadian Transportation and Logistics, June 1, 2006, 16.

Sodhi, M. S., \& Lee, S. (2007). An Analysis of Sources of Risk in the Consumer Electronics Industry. The Journal of the Operational Research Society, 58(11), 1430-1439.

Sodhi, M. S., Son, B.-G., \& Tang, C. S. (2012). Researchers' Perspectives on Supply Chain Risk Management. Production and Operations Management, 21(1), 1-13.

Sodhi, M. S., \& Tang, C. S. (2009). Modeling supply-chain planning under demand uncertainty using stochastic programming: A survey motivated by asset-liability management. International Journal of Production Economics, 121, 728-738.

Sodhi, M. S., \& Tang, C. S. (2012). Managing Supply Chain Risk. New York: Springer Science + Business Media.

Speier, C., Whipple, J. M., Closs, D. J., \& Voss, M. D. (2011). Global supply chain design considerations: Mitigating product safety and security risks. Journal of Operations Management, 29, 721-736.

Spekman, R. E., \& Davis, E. W. (2004). Risky business: expanding the discussion on risk and the extended enterprise. International Journal of Physical Distribution \& Logistics Management, 34(5), 414-433.

Sterman, J. D. (2004). Business Dynamics: Systems Thinking and Modeling for a Complex World (International ed.). Boston: McGraw Hill.

Subin, R. (2011). Country: India's Cold Chain Industry: U.S. Commercial Service.

Sutton, J. (2004). The Auto-component Supply Chain in China and India-A Benchmark Study. LSE STICERD Research Paper No. EI34.

Svensson, G. (2002). A conceptual framework of vulnerability in firms' inbound and outbound logistics flows. International Journal of Physical Distribution \& Logistics Management, 32(2), 110-134.

Swafford, P. M., Ghosh, S., \& Murthy, N. (2006). The antecedents of supply chain agility of a firm: Scale development and model testing. Journal of Operations Management, 24, 170-188. 
Swaminathan, J. M., Smith, S. F., \& Sadeh, N. M. (1998). Modeling supply chain dynamics: A multiagent approach*. Decision Sciences, 29(3), 607-632.

Swaminathan, J. M., \& Tomlin, B. (2007). How to avoid the 6 risk management pitfalls. Supply Chain Management Review(July/August 2007), 35-42.

Sweet, K. M. (2006). Transportation and Cargo Security: Threats and Solutions. Upper Saddle River, NJ: Pearson Prentice Hall.

Swiss-Re. (2012). Natural catastrophies and man-made disasters in 2011: historic losses surface from record earthquakes and floods. In J. V. Cordova (Ed.), SIGMA (Vol. 2). Zurich, Switzerland.

Takahashi, Y. (2012, April 23, 2012). Japanese Auto Makers Riding Out Resin Supply Problem, The Wall Street Journal.

Tang, C., \& Tomlin, B. (2008). The power of flexibility for mitigating supply chain risks. International Journal of Production Economics, 116, 12-27.

Tang, C. S. (2006a). Perspectives in supply chain risk management. International Journal of Production Economics, 103, 451-488.

Tang, C. S. (2006b). Robust strategies for mitigating supply chain disruptions. International Journal of Logistics Research and Applications, 9(1), 33-45.

Tang, O., \& Musa, S. N. (2011). Identifying risk issues and research advancements in supply chain risk management. International Journal of Production Economics, 133, 25-34.

Tatham, P., Oloruntoba, R., \& Spens, K. (2012). Cyclone preparedness and response: an analysis of lessons identified using an adapted military planning framework. Disasters, 36(1), 5482.

The_Economist. (2010). Toyota's overstretched supply chain: The machine that ran too hot. The Economist Newspaper.

The_Economist. (2013). Special Report: Outsourcing and Offshoring. Here, there and everywhere. . The Economist Magazine.

Thun, J.-H., \& Hoenig, D. (2011). An empirical analysis of supply chain risk management in the German automotive industry. International Journal Production Economics, 131, 242-249.

Tomlin, B. (2006). On the Value of Mitigation and Contingency Strategies for Managing Supply Chain Disruption Risks. Management Science, 52(5), 639-657.

Trent, R. J., \& Roberts, L. R. (2010). Managing Global Supply and Risk - Best Practices, Concepts, and Strategies. Fort Lauderdale: J. Ross Publishing, Inc.

Triola, M. F. (2008). Elementary Statistics (10th ed.). Boston: Pearson Education, Inc. .

Trkman, P., \& McCormack, K. (2009). Supply chain risk in turbulent environments - A conceptual model for managing supply chain network risk. International Journal of Production Economics, 119, 247-258.

TSA. (2010). Transportation Systems Sector-Specific Plan: An Annex to the National Infrastructure Protection Plan. Washington, DC: U.S. Department of Homeland Security Retrieved from

http://www.tsa.gov/sites/default/files/assets/pdf/transportation systems ssp web.pdf

Tummala, R., \& Schoenherr, T. (2011). Assessing and managing risks using the Supply Chain Risk Management Process (SCRMP). Supply Chain Management: An International Journal, 16(6), 474-483.

Tversky, A., \& Kahneman, D. (1974). Judgment under Uncertainty: Heuristics and Biases. Science, 185(4157), 1124-1131. 
Udbye, A. (2013). Global Supply Chains, Disasters and Externalities: How complex supply networks create damaging externalities and its consequences. Paper presented the International Society for Systems Sciences, Haiphong, Vietnam.

Vanany, I., Zailani, S., \& Pujawan, N. (2009). Supply chain risk management: Literature review and future research. International Journal of Information Systems and Supply Chain Management, 2(1), 16-33.

Vanderspek, P. (2012). Strategies for Reducing Supply Chain Risk. Supply Chain Brain.

Verstraete, C. (2008). Share and share alike. CSCMP's Supply Chain Quarterly(Quarter 2, 2008).

Vilko, J., Edelmann, J., \& Hallikas, J. (2010). Defining the levels of uncertainty in supply chains. http://www.emara.ee/bw client files/mereakadeemia/public/img/File/Microsoft Wor $\mathrm{d}$ - Defining the levels of uncertainty in supply chains Jyri Vilko .pdf

Vilko, J., \& Hallikas, J. (2011). Risk control and collaboration in maritime supply chains. Paper presented at the 16th International Symposium on Logistics (ISL 2011), Berlin.

Wagner, S., \& Bode, C. (2006). An empirical investigation into supply chain vulnerability experienced by German firms. In W. Kersten \& T. Blecker (Eds.), Managing Risks in Supply Chains: How to build reliable collaboration in logistics (pp. 79-96). Berlin: Erich Schmidt Verlag.

Wagner, S. M., \& Bode, C. (2006). An empirical investigation into supply chain vulnerability. Journal of Purchasing \& Supply Management, 12(6), 301-312.

Wagner, S. M., \& Bode, C. (2008). An empirical examination of supply chain performance along several dimensions of risk. Journal of Business Logistics, 29(1), 307-325.

Wagner, S. M., \& Bode, C. (2009). Managing Risk and Security: The Safeguard of Long-Term Success for Logistics Service Providers. Berne, Switzerland: Haupt Publisher.

Wan, W. (2012, Sept. 26, 2012). Foxconn riot highlights working conditions, economic woes, The Washington Post.

Waner, S., \& Costenoble, S. R. (2007). Finite Mathematics and Applied Calculus (4th ed.). Belmont, AC: Thomson Brooks/Cole.

Waters, C. D. J. (2011). Supply chain risk management: vulnerability and resilience in logistics (2nd ed.). London Kogan Page.

Watts, D. J. (2003). Six Degrees: The Science of a Connected Age. New York: W.W. Norton \& Co.

Webb, J. (2012). Indian supply chain security risk: an underestimated threat? Retrieved from procurement-iu.com website: http://www.procurementiu.com/blog/2011/1/indian supply chain security risk an underestimated threat

Whitty, J. (2010). The Last Taboo: There are 7 billion humans on earth, so why can't we talk about population? Mother Jones, (May/June 2010).

http://www.motherjones.com/environment/2010/05/population-growth-indiavatican?page $=1$

Williams, Z., Lueg, J. E., \& LeMay, S. A. (2008). Supply chain security: an overview and research agenda. The International Journal of Logistics Management, 19(2), 254-281.

Wise, M. (2013). No horsing around with supply chain risk. Supply Chain Risk Review, (First quarter, 2013).

WMO. (2012). Tropical Cyclone Operational Plan for the South-West Indian Ocean Technical Document (2012 ed.). Geneva: World Meteorological Organization.

Wolpert, S. (2009). India (4th ed.). Berkeley, CA: University of California Press.

World_Bank, T. (2012). Doing Business 2012: Economy Profile: India. Washington, DC: The World Bank Group Retrieved from http://www.doingbusiness.org/data/exploreeconomies/india. 
World_Economic_Forum. (2012a). Global Competitiveness Report 2012-2013, India Country/Economic Profile. Geneva: World Economic Forum.

World_Economic_Forum. (2012b). New Models for Addressing Supply Chain and Transport Risk. Industry Agenda. http://www3.weforum.org/docs/WEF SCT RRN NewModelsAddressingSupplyChainTra nsportRisk IndustryAgenda 2012.pdf

Wu, D., \& Olson, D. L. (2008). Supply chain risk, simulation, and vendor selection. International Journal of Production Economics, 114, 646-655.

Yates, J. F., \& Stone, E. R. (1992). The Risk Construct. In J. F. Yates (Ed.), Risk Taking Behaviour (pp. 3-25). Chichester, UK: John Wiley \& Sons.

Yee, D. (2009). Managing Risk in Your Organization with the SCOR Methodology: Supply Chain Council, Inc.

Yuan, C., Cheng, F., Dao, H., Ettl, M., Lin, G., \& Sourirajan, K. (2012). A Bayesian Framework for Supply Chain Risk Management Using Business Process Standards. In P. Kouvelis, L. Dong, O. Boyabatli \& R. Li (Eds.), The Handbook of Integrated Risk Management in Global Supply Chains. Hoboken, NJ: John Wiley \& Sons, Inc.

Zsidisin, G. A. (2003a). A grounded definition of supply risk. Journal of Purchasing \& Supply Management, 9(5-6), 217-224.

Zsidisin, G. A. (2003b). Managerial perceptions of supply risk. Journal of Supply Chain Management, 39(1), 14-25.

Zsidisin, G. A., \& Ellram, L. M. (2003). An Agency Theory Investigation of Supply Risk Management. The Journal of Supply Chain Management, 39(3), 15-27.

Zsidisin, G. A., Ellram, L. M., Carter, J. R., \& Cavinato, J. L. (2004). An analysis of supply risk assessment techniques. International Journal of Physical Distribution \& Logistics Management, 34(5), 397-413.

Zsidisin, G. A., Panelli, A., \& Upton, R. (2000). Purchasing organization involvement in risk assessments, contingency plans, and risk management: an exploratory study. Supply Chain Managenent: An International Journal, 5(4), 187-198.

Zsidisin, G. A., Ragatz, G. L., \& Melnyk, S. A. (2004). Effective practices and tools for ensuring supply continuity. In C. Brindley (Ed.), Supply Chain Risk. Aldershot, UK: Ashgate Publishing Company.

Zsidisin, G. A., \& Ritchie, B. (2008). Supply chain risk : a handbook of assessment, management, and performance. New York: Springer.

Zsidisin, G. A., \& Smith, M. E. (2005). Managing Supply Chain Risk with Early Supplier Involvement: A Case Study and Research Propositions. The Journal of Supply Chain Management, 41(4), 44-57. 


\section{APPENDIX A: COPY OF THE SURVEY}

\section{Indian Supply Chain Risks Survey}

\section{Portland State}

Q1. Is your company sourcing in India or producing goods or services in India?

O Yes (1)

O No (2)

If No Is Selected, Then Skip To End of Survey

Q2. What is your organizational level? (Choose one)

O Chair, Owner, CEO, President (1)

O Managing Director, VP, General Manager, C-Level Executive (2)

Director, Senior Manager (3)

O Manager (4)

Analyst, Specialist, Coordinator, Consultant (5)

O Other (6)

Q3. What is your functional area within the company? (Choose all that apply)

$\square$ General management (1)

- Supply chain management (incl. procurement, logistics, transportation) (2)

- Financial management (incl. accounting and I.T.) (3)

- Sales and marketing management (4)

- Production and manufacturing management (5)

Engineering and product development (6)

Human resource management (7)

$\square$ Other (8)

Q4. What is your company's general sector(s)? (Choose all that apply)

- Non-durable goods or consumables (1)

Durable goods (2)

Capital goods (buildings, machines, heavy equipment, etc.) (3)

Natural resources (4)

Services, incl. software, IT, education and government (5)

Q5. In which country is your company's global headquarters located? (Write in)

O India (1) $\quad 36$

Other than India (write in):

Q6. What is your company's ownership? (Choose one)

Fully Indian (1)

Fully foreign (2)

Mixed, with majority Indian owned (4)

Mixed, with majority foreign owned (5) 
Q7. The company... (Choose all that apply)

Owns and operates its own production or development facilities in India (1)

- Sources from Indian companies (2)

$\square$ Other or none of the above (3)

Q8. Which businesses are your company involved with globally (incl. India)? (Choose all that apply) [The categories correspond to the National Industrial Classification 2008]

A. Agriculture, forestry or fishing (1)

B. Mining or quarrying (2)

C. Manufacturing (3)

D. Electricity, gas, steam or air conditioning supply (4)

E. Water supply, sewerage, waste management or remediation activities (5)

F. Construction (6)

G. Wholesale and retail trade, repair of motor vehicles or motorcycles (7)

H. Transportation or storage (8)

I. Accommodation or food service activities (9)

J. Information or communication, incl. software or IT services (10)

G. Financial or insurance activities (11)

L. Real estate activities (12)

M. Professional, scientific or technical activities (13)

N. Administrative or support service activities (14)

O. Public administration or defense; compulsory social security (15)

P. Education (16)

Q. Human health or social work activities (17)

R. Arts, entertainment or recreation (18)

S. Other service activities, incl. trade associations (19)

T. Activities of households as employers, indifferentiated goods- and services producing activities of households for own use (20)

U. Activities of extraterritorial organizations or bodies (21)

Q9. What are your company's annual global sales in U.S. dollars? (Choose one) Approximate exchange rate is 50 INR to the dollar.

O Less than US\$1,000,000 (1)

O US\$ $1,000,000-10,000,000(2)$

O US\$10,000,000-100,000,000 (3)

O US\$100,000,000-1,000,000,000 (4)

O US\$1,000,000,000-10,000,000,000 (5)

O More than US\$10,000,000,000 (6)

Q10. What kind of activity does your company do in India? (Choose all that apply)

Production or development, incl. goods or all kinds of services (1)

Marketing and Sales (2)

Sourcing (3)

口 Other (4) 
Q11. Which categories of goods or services does your company source or produce in India? (Choose all that apply) [The categories correspond to the official ones used by Reserve Bank of India and the International Monetary Fund]

Agricultural and allied products (incl. meat, fish) (1)

$\square$ Ores and minerals (2)

Leather and manufactures (3)

Chemicals and related products (incl. pharmaceuticals, cosmetics) (4)

Engineered goods (incl. transportation equipment, machinery) (5)

Textiles and textile products (6)

Gems and jewelry (7)

- Handicrafts (8)

Other manufactured goods (9)

口 Petroleum products (10)

Electricity, gas or water supply (11)

$\square$ Other products (12)

Transportation services (goods or passengers) (13)

Travel, hospitality, tourism (14)

- Telecommunications, computer or information services (incl. IT, software, BPO, ITES, media) (15)

Construction services, incl. architecture (16)

Insurance services (17)

Financial services, incl. banking (18)

Other business services, (incl. accounting, law, consulting, R\&D, storage) (19)

- Personal, cultural or recreational services (incl. audiovisual, educational) (20)

Government goods or services (21)

- Maintenance, repairs or manufacturing services (22)

Q12. What is the annual value of what your company is sourcing, producing or developing (incl. services) in India, in Indian Rupees? (Choose one)

L Less than INR 10,00,000 (10 lakhs) (1)

O INR $10,00,000-1,00,00,000$ (10 lakhs to 1 crore) (2)

O INR $1,00,00,000-10,00,00,000$ ( 1 crore to 10 crores) (3)

O INR $10,00,00,000-1,00,00,00,000$ (10 crores to 100 crores) (4)

O INR $1,00,00,00,000-10,00,00,00,000$ (100 crores to 1,000 crores) (5)

More than INR $10,00,00,00,000$ (more than 1,000 crores) (6)

Q13. How many persons does your company directly employ in India? (Choose one)
O None (7)
O 1-10 (1)
O $11-100(2)$
O $101-1,000(3)$
O 1,001-10,000 (4)
O $10,001-100,000$ (5)
O 100,001 or more (6) 
Q14. What percentage of your company's products or services sourced or produced in India is exported out of India (i.e. sold abroad)? (Choose one)
O $100 \%(1)$
O $75-99 \%(2)$
O $50-74 \%(3)$
O $25-49 \%(4)$
O $1-24 \%(5)$
$0 \%(6)$
Don't know (7)

Q15. Where are the locations of your major Indian suppliers and/or your major Indian production facilities (incl. services)? (Choose all that apply)

$\square$ Central India (1)
$\square \quad$ East India (2)
$\square$ North India (3)
$\square$ North-East India (4)
$\square$ South India (5)
$\square$ West India (6)

Q16. For how many years has your company been sourcing or producing in India? (Choose one)

$O$ Less than 3 years (1)

O $3-10$ years (2)

O $10-20$ years (3)

O More than 20 years (4)

Don't know (5)

You are now presented with thirteen categories of disruptions that could affect supply chain operations in India. We ask how often any of these disruptions may have affected your company for the past three years, what the negative impacts may have been, whether any of five mitigation methods helped to prevent or limit the impact, and which of these disruptions you expect to encounter over the next three years. There is also room to write in up to two additional disruptions or risks if you don't find them on the list. ("Disruption" can be defined as an unexpected event that throws the supply chain into minor or major disorder.) 


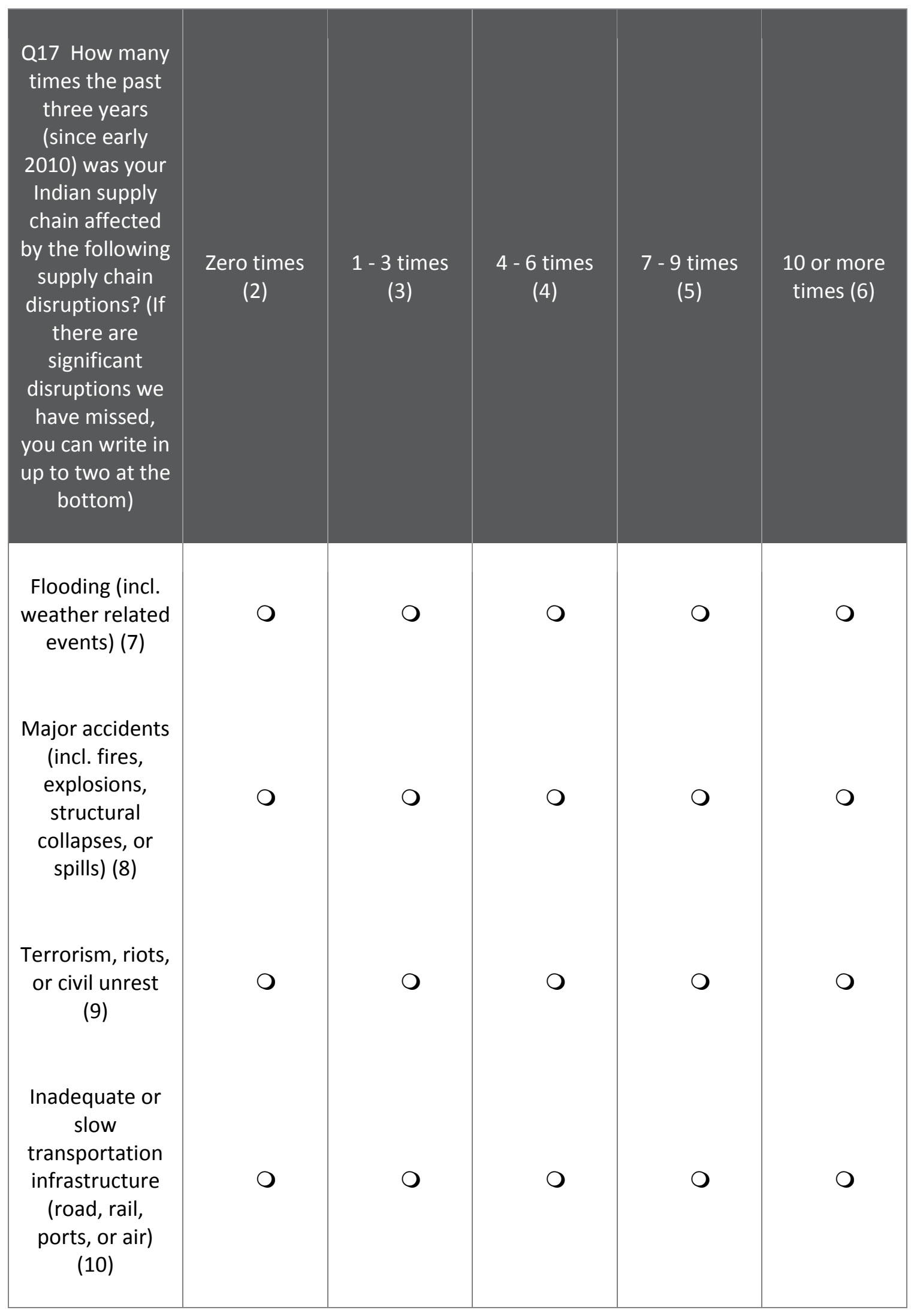




\begin{tabular}{|c|c|c|c|c|c|}
\hline $\begin{array}{c}\text { Inadequate } \\
\text { logistics } \\
\text { infrastructure } \\
\text { (distribution, } \\
\text { warehousing, } \\
\text { or cold storage) } \\
\text { (11) }\end{array}$ & 0 & 0 & 0 & 0 & 0 \\
\hline $\begin{array}{c}\text { Inadequate } \\
\text { utilities } \\
\text { infrastructure } \\
\text { (electricity, } \\
\text { water, sewer, } \\
\text { telephone, or } \\
\text { internet) (12) }\end{array}$ & 0 & 0 & 0 & 0 & 0 \\
\hline $\begin{array}{l}\text { Property or } \\
\text { violent crimes } \\
\text { (theft, robbery, } \\
\text { hijackings, } \\
\text { vandalism, } \\
\text { computer } \\
\text { viruses or } \\
\text { fraud) (13) }\end{array}$ & 0 & 0 & $\mathrm{O}$ & 0 & 0 \\
\hline $\begin{array}{c}\text { Intellectual } \\
\text { property crimes } \\
\text { (counterfeiting, } \\
\text { copyright } \\
\text { violations, or } \\
\text { hacking) (14) }\end{array}$ & 0 & 0 & 0 & 0 & 0 \\
\hline $\begin{array}{l}\text { Corruption or } \\
\text { bribery (15) }\end{array}$ & 0 & 0 & 0 & 0 & 0 \\
\hline
\end{tabular}




\begin{tabular}{|c|c|c|c|c|c|}
\hline $\begin{array}{l}\text { Bureaucracy } \\
\text { (red tape, } \\
\text { unclear, } \\
\text { inconsistent } \\
\text { restrictions or } \\
\text { regulations) } \\
(16)\end{array}$ & 0 & 0 & 0 & 0 & 0 \\
\hline $\begin{array}{l}\text { Labor problems } \\
\text { (strikes, skills } \\
\text { shortages, } \\
\text { incompetence, } \\
\text { turnover, or } \\
\text { absenteeism) } \\
\text { (17) }\end{array}$ & 0 & 0 & 0 & 0 & 0 \\
\hline $\begin{array}{c}\text { Tax system } \\
\text { (burdensome, } \\
\text { arbitrary, or } \\
\text { inconsistent) } \\
\text { (18) }\end{array}$ & 0 & 0 & 0 & 0 & 0 \\
\hline $\begin{array}{l}\text { Supplier } \\
\text { problems } \\
\text { (quality, } \\
\text { reliability, } \\
\text { timeliness, or } \\
\text { financial } \\
\text { strength) (19) }\end{array}$ & 0 & 0 & 0 & 0 & 0 \\
\hline $\begin{array}{c}\text { Write in } \\
\text { additional } \\
\text { significant } \\
\text { disruption: (4) }\end{array}$ & 0 & 0 & 0 & 0 & 0 \\
\hline
\end{tabular}




\begin{tabular}{|c|c|c|c|c|c|}
\hline $\begin{array}{c}\text { Write in } \\
\text { additional } \\
\text { significant } \\
\text { disruption: (5) }\end{array}$ & 0 & 0 & 0 & 0 & 0 \\
\hline
\end{tabular}




\begin{tabular}{|c|c|c|c|c|c|}
\hline $\begin{array}{l}\text { Q18 Please indicate the } \\
\text { operational impact of the } \\
\text { disruptions you checked in the } \\
\text { previous question (choose one per } \\
\text { risk): }\end{array}$ & $\begin{array}{l}\text { No } \\
\text { impact } \\
\text { (1) }\end{array}$ & $\begin{array}{l}\text { Minor } \\
\text { impact } \\
(2)\end{array}$ & $\begin{array}{l}\text { Moderate } \\
\text { impact } \\
\text { (3) }\end{array}$ & $\begin{array}{l}\text { Major } \\
\text { impact } \\
(4)\end{array}$ & $\begin{array}{l}\text { Catastrophic } \\
\text { impact (5) }\end{array}$ \\
\hline $\begin{array}{l}\text { Flooding (incl. weather related } \\
\text { events) (1) }\end{array}$ & $\mathrm{O}$ & $\mathrm{O}$ & O & O & O \\
\hline $\begin{array}{l}\text { Major accidents (incl. fires, } \\
\text { explosions, structural collapses, or } \\
\text { spills) (2) }\end{array}$ & $\mathrm{O}$ & $\mathrm{O}$ & O & $\mathrm{O}$ & O \\
\hline Terrorism, riots, or civil unrest (3) & $\mathrm{O}$ & $\mathrm{O}$ & $\mathrm{O}$ & $\mathrm{O}$ & O \\
\hline $\begin{array}{l}\text { Inadequate or slow transportation } \\
\text { infrastructure (road, rail, ports, or } \\
\text { air) (4) }\end{array}$ & O & $\mathrm{O}$ & $\mathrm{O}$ & O & $\mathrm{O}$ \\
\hline $\begin{array}{c}\text { Inadequate logistics infrastructure } \\
\text { (distribution, warehousing, or cold } \\
\text { storage) (5) }\end{array}$ & O & O & O & O & O \\
\hline $\begin{array}{l}\text { Inadequate utilities infrastructure } \\
\text { (electricity, water, sewer, } \\
\text { telephone, or internet) (6) }\end{array}$ & O & O & O & $\mathrm{O}$ & O \\
\hline $\begin{array}{l}\text { Property or violent crimes (theft, } \\
\text { robbery, hijackings, vandalism, } \\
\text { computer viruses or fraud) (7) }\end{array}$ & O & O & O & O & $\mathrm{O}$ \\
\hline $\begin{array}{l}\text { Intellectual property crimes } \\
\text { (counterfeiting, copyright } \\
\text { violations, or hacking) (8) }\end{array}$ & $\mathrm{O}$ & O & O & O & $\mathrm{O}$ \\
\hline
\end{tabular}




\begin{tabular}{|c|c|c|c|c|c|}
\hline Corruption or bribery (9) & $\mathrm{O}$ & $\mathrm{O}$ & $\mathrm{O}$ & O & O \\
\hline $\begin{array}{l}\text { Bureaucracy (red tape, unclear, } \\
\text { inconsistent restrictions, or } \\
\text { regulations) (10) }\end{array}$ & $\mathrm{O}$ & $\mathrm{O}$ & O & O & O \\
\hline $\begin{array}{l}\text { Labor problems (strikes, skills } \\
\text { shortages, incompetence, } \\
\text { turnover, or absenteeism) (11) }\end{array}$ & $\mathrm{O}$ & $\mathrm{O}$ & $\mathrm{O}$ & $\mathrm{O}$ & ○ \\
\hline $\begin{array}{l}\text { Tax system (burdensome, } \\
\text { arbitrary, or inconsistent) (12) }\end{array}$ & O & ○ & $\bigcirc$ & $\bigcirc$ & $\bigcirc$ \\
\hline $\begin{array}{l}\text { Supplier problems (quality, } \\
\text { reliability, timeliness, or financial } \\
\text { strength) (13) }\end{array}$ & O & O & $\mathrm{O}$ & O & $\mathrm{O}$ \\
\hline Other 1 (14) & ○ & O & ○ & O & O \\
\hline Other 2 (15) & 0 & 0 & 0 & 0 & 0 \\
\hline
\end{tabular}

\section{MITIGATION METHODS}

Were any mitigation methods useful in preventing or limiting the negative impact of the disruptions you picked? Mitigation in this context means "efforts that help to prevent a disruption or make it less severe or painful". The mitigation methods we ask you to evaluate are:

Buffering: Have safety inventories, extended lead times or excess capacity Redundancy: Have multiple suppliers, sites or equipment

Flexibility: Have suppliers or facilities that can quickly respond, adjust, or change over Visibility: Collaborate with and get timely information from trusted suppliers, customers and service providers

Insource: $\quad$ Produce and source internally instead of relying on outside suppliers or sources, or integrate vertically 


\section{Q19a. Flooding:}

In your opinion, how useful were these mitigation methods in preventing or limiting the negative impact on your supply chain of the flooding (incl. weather related events)?

\begin{tabular}{|c|c|c|c|c|c|}
\hline & $\begin{array}{c}\text { Not useful } \\
\text { at all (1) }\end{array}$ & $\begin{array}{l}\text { Somewhat } \\
\text { useful (2) }\end{array}$ & Useful (3) & $\begin{array}{l}\text { Very useful } \\
\text { (4) }\end{array}$ & $\begin{array}{c}\text { Not } \\
\text { applicable (5) }\end{array}$ \\
\hline $\begin{array}{l}\text { Buffering: } \\
\text { Inventory, } \\
\text { lead time or } \\
\text { capacity (1) }\end{array}$ & 0 & 0 & 0 & 0 & 0 \\
\hline $\begin{array}{l}\text { Redundancy: } \\
\text { Multiple } \\
\text { suppliers, } \\
\text { sites or } \\
\text { equipment (2) }\end{array}$ & 0 & 0 & 0 & 0 & 0 \\
\hline $\begin{array}{l}\text { Flexibility: } \\
\text { Quick } \\
\text { response or } \\
\text { change-overs } \\
\text { (3) }\end{array}$ & 0 & 0 & 0 & 0 & 0 \\
\hline $\begin{array}{l}\text { Visibility: } \\
\text { Collaboration } \\
\text { and timely } \\
\text { info from } \\
\text { supply chain } \\
\text { partners (4) }\end{array}$ & 0 & 0 & 0 & 0 & 0 \\
\hline $\begin{array}{l}\text { Insource : } \\
\text { Produce } \\
\text { internally or } \\
\text { vertical } \\
\text { integration (5) }\end{array}$ & 0 & 0 & 0 & O & 0 \\
\hline
\end{tabular}




\section{Q19b. Major accidents:}

In your opinion, how useful were these mitigation methods in preventing or limiting the negative impact on your supply chain of the major accidents (fires, explosions,structural collapses or spills)?

\begin{tabular}{|c|c|c|c|c|c|}
\hline & $\begin{array}{l}\text { Not useful } \\
\text { at all (1) }\end{array}$ & $\begin{array}{l}\text { Somewhat } \\
\text { useful (2) }\end{array}$ & Useful (3) & $\begin{array}{l}\text { Very useful } \\
\text { (4) }\end{array}$ & $\begin{array}{c}\text { Not } \\
\text { applicable (5) }\end{array}$ \\
\hline $\begin{array}{l}\text { Buffering: } \\
\text { Inventory, } \\
\text { lead time or } \\
\text { capacity (1) }\end{array}$ & 0 & $\mathrm{O}$ & $\mathrm{O}$ & 0 & O \\
\hline $\begin{array}{l}\text { Redundancy: } \\
\text { Multiple } \\
\text { suppliers, } \\
\text { sites or } \\
\text { equipment (2) }\end{array}$ & $\mathrm{O}$ & O & 0 & $\mathrm{O}$ & O \\
\hline $\begin{array}{c}\text { Flexibility: } \\
\text { Quick } \\
\text { response or } \\
\text { change-overs } \\
\text { (3) }\end{array}$ & 0 & $\mathrm{O}$ & 0 & 0 & 0 \\
\hline $\begin{array}{l}\text { Visibility: } \\
\text { Collaboration } \\
\text { and timely } \\
\text { info from } \\
\text { supply chain } \\
\text { partners (4) }\end{array}$ & 0 & $\mathrm{O}$ & 0 & $\mathrm{O}$ & 0 \\
\hline $\begin{array}{l}\text { Insource : } \\
\text { Produce } \\
\text { internally or } \\
\text { vertical } \\
\text { integration (5) }\end{array}$ & 0 & $\mathrm{O}$ & 0 & 0 & 0 \\
\hline
\end{tabular}


Q19c. Terrorism, riots or civil unrest:

In your opinion, how useful were these mitigation methods in preventing or limiting the negative impact on your supply chain of the terrorism, riots or civil unrest?

\begin{tabular}{|c|c|c|c|c|c|}
\hline & $\begin{array}{l}\text { Not useful } \\
\text { at all (1) }\end{array}$ & $\begin{array}{l}\text { Somewhat } \\
\text { useful (2) }\end{array}$ & Useful (6) & $\begin{array}{l}\text { Very useful } \\
\text { (3) }\end{array}$ & $\begin{array}{c}\text { Not } \\
\text { applicable (4) }\end{array}$ \\
\hline $\begin{array}{l}\text { Buffering: } \\
\text { Inventory, } \\
\text { lead time or } \\
\text { capacity (1) }\end{array}$ & 0 & 0 & 0 & O & 0 \\
\hline $\begin{array}{l}\text { Redundancy: } \\
\text { Multiple } \\
\text { suppliers, } \\
\text { sites or } \\
\text { equipment (2) }\end{array}$ & O & $\mathrm{O}$ & 0 & O & $\mathrm{O}$ \\
\hline $\begin{array}{l}\text { Flexibility: } \\
\text { Quick } \\
\text { response or } \\
\text { change-overs } \\
\text { (3) }\end{array}$ & O & $\mathrm{O}$ & 0 & O & 0 \\
\hline $\begin{array}{l}\text { Visibility: } \\
\text { Collaboration } \\
\text { and timely } \\
\text { info from } \\
\text { supply chain } \\
\text { partners (4) }\end{array}$ & 0 & 0 & 0 & $\mathrm{O}$ & 0 \\
\hline $\begin{array}{l}\text { Insource : } \\
\text { Produce } \\
\text { internally or } \\
\text { vertical } \\
\text { integration (5) }\end{array}$ & O & 0 & 0 & 0 & $\mathrm{O}$ \\
\hline
\end{tabular}




\section{Q19d. Inadequate or slow transportation infrastructure:}

In your opinion, how useful were these mitigation methods in preventing or limiting the negative impact on your supply chain of the inadequate or slow transportation infrastructure?

\begin{tabular}{|c|c|c|c|c|c|}
\hline & $\begin{array}{c}\text { Not useful } \\
\text { at all (1) }\end{array}$ & $\begin{array}{c}\text { Somewhat } \\
\text { useful (2) }\end{array}$ & Useful (3) & $\begin{array}{l}\text { Very useful } \\
\text { (4) }\end{array}$ & $\begin{array}{c}\text { Not } \\
\text { applicable (5) }\end{array}$ \\
\hline $\begin{array}{l}\text { Buffering: } \\
\text { Inventory, } \\
\text { lead time or } \\
\text { capacity (1) }\end{array}$ & 0 & 0 & 0 & 0 & $\mathrm{O}$ \\
\hline $\begin{array}{l}\text { Redundancy: } \\
\text { Multiple } \\
\text { suppliers, } \\
\text { sites or } \\
\text { equipment (2) }\end{array}$ & $\mathrm{O}$ & 0 & 0 & 0 & O \\
\hline $\begin{array}{c}\text { Flexibility: } \\
\text { Quick } \\
\text { response or } \\
\text { change-overs } \\
\text { (3) }\end{array}$ & 0 & 0 & 0 & 0 & 0 \\
\hline $\begin{array}{l}\text { Visibility: } \\
\text { Collaboration } \\
\text { and timely } \\
\text { info from } \\
\text { supply chain } \\
\text { partners (4) }\end{array}$ & 0 & 0 & 0 & 0 & $\mathrm{O}$ \\
\hline $\begin{array}{l}\text { Insource: } \\
\text { Produce } \\
\text { internally or } \\
\text { vertical } \\
\text { integration (5) }\end{array}$ & 0 & 0 & 0 & 0 & 0 \\
\hline
\end{tabular}


Q19e. Inadequate logistics infrastructure:

In your opinion, how useful were these mitigation methods in preventing or limiting the negative impact on your supply chain of the inadequate logistics infrastructure (distribution, warehousing or cold storage)?

\begin{tabular}{|c|c|c|c|c|c|}
\hline & $\begin{array}{l}\text { Not useful } \\
\text { at all (1) }\end{array}$ & $\begin{array}{l}\text { Somewhat } \\
\text { useful (2) }\end{array}$ & Useful (3) & $\begin{array}{l}\text { Very useful } \\
\text { (4) }\end{array}$ & $\begin{array}{c}\text { Not } \\
\text { applicable (5) }\end{array}$ \\
\hline $\begin{array}{l}\text { Buffering: } \\
\text { Inventory, } \\
\text { lead time or } \\
\text { capacity (1) }\end{array}$ & 0 & $\mathrm{O}$ & $\mathrm{O}$ & 0 & O \\
\hline $\begin{array}{l}\text { Redundancy: } \\
\text { Multiple } \\
\text { suppliers, } \\
\text { sites or } \\
\text { equipment (2) }\end{array}$ & $\mathrm{O}$ & O & 0 & $\mathrm{O}$ & O \\
\hline $\begin{array}{c}\text { Flexibility: } \\
\text { Quick } \\
\text { response or } \\
\text { change-overs } \\
\text { (3) }\end{array}$ & 0 & $\mathrm{O}$ & 0 & 0 & 0 \\
\hline $\begin{array}{l}\text { Visibility: } \\
\text { Collaboration } \\
\text { and timely } \\
\text { info from } \\
\text { supply chain } \\
\text { partners (4) }\end{array}$ & 0 & $\mathrm{O}$ & 0 & $\mathrm{O}$ & 0 \\
\hline $\begin{array}{l}\text { Insource : } \\
\text { Produce } \\
\text { internally or } \\
\text { vertical } \\
\text { integration (5) }\end{array}$ & 0 & $\mathrm{O}$ & 0 & 0 & 0 \\
\hline
\end{tabular}


Q19f. Inadequate utilities infrastructure:

In your opinion, how useful were these mitigation methods in preventing or limiting the negative impact on your supply chain of the inadequate utiities infrastructure (electricity, water, sewer, telephone, internet)?

\begin{tabular}{|c|c|c|c|c|c|}
\hline & $\begin{array}{l}\text { Not useful } \\
\text { at all (1) }\end{array}$ & $\begin{array}{l}\text { Somewhat } \\
\text { useful (2) }\end{array}$ & Useful (3) & $\begin{array}{l}\text { Very useful } \\
\text { (4) }\end{array}$ & $\begin{array}{c}\text { Not } \\
\text { applicable (5) }\end{array}$ \\
\hline $\begin{array}{l}\text { Buffering: } \\
\text { Inventory, } \\
\text { lead time or } \\
\text { capacity (1) }\end{array}$ & 0 & 0 & 0 & 0 & 0 \\
\hline $\begin{array}{l}\text { Redundancy: } \\
\text { Multiple } \\
\text { suppliers, } \\
\text { sites or } \\
\text { equipment (2) }\end{array}$ & $\mathrm{O}$ & 0 & $\mathrm{O}$ & 0 & O \\
\hline $\begin{array}{l}\text { Flexibility: } \\
\text { Quick } \\
\text { response or } \\
\text { change-overs } \\
\text { (3) }\end{array}$ & 0 & 0 & 0 & 0 & O \\
\hline $\begin{array}{l}\text { Visibility: } \\
\text { Collaboration } \\
\text { and timely } \\
\text { info from } \\
\text { supply chain } \\
\text { partners (4) }\end{array}$ & 0 & 0 & 0 & 0 & 0 \\
\hline $\begin{array}{l}\text { Insource : } \\
\text { Produce } \\
\text { internally or } \\
\text { vertical } \\
\text { integration (5) }\end{array}$ & 0 & 0 & 0 & 0 & \\
\hline
\end{tabular}




\section{Q19g. Property or violent crimes:}

In your opinion, how useful were these mitigation methods in preventing or limiting the negative impact on your supply chain of the property or violent crimes (theft, robbery, hijackings, vandalism, computer viruses or fraud)?

\begin{tabular}{|c|c|c|c|c|c|}
\hline & $\begin{array}{l}\text { Not useful } \\
\text { at all (1) }\end{array}$ & $\begin{array}{l}\text { Somewhat } \\
\text { useful (2) }\end{array}$ & Useful (3) & $\begin{array}{l}\text { Very useful } \\
\text { (4) }\end{array}$ & $\begin{array}{c}\text { Not } \\
\text { applicable (5) }\end{array}$ \\
\hline $\begin{array}{l}\text { Buffering: } \\
\text { Inventory, } \\
\text { lead time or } \\
\text { capacity (1) }\end{array}$ & 0 & 0 & 0 & 0 & 0 \\
\hline $\begin{array}{l}\text { Redundancy: } \\
\text { Multiple } \\
\text { suppliers, } \\
\text { sites or } \\
\text { equipment (2) }\end{array}$ & 0 & 0 & $\mathrm{O}$ & $\mathrm{O}$ & $\mathrm{O}$ \\
\hline $\begin{array}{c}\text { Flexibility: } \\
\text { Quick } \\
\text { response or } \\
\text { change-overs } \\
\text { (3) }\end{array}$ & 0 & 0 & 0 & 0 & 0 \\
\hline $\begin{array}{l}\text { Visibility: } \\
\text { Collaboration } \\
\text { and timely } \\
\text { info from } \\
\text { supply chain } \\
\text { partners (4) }\end{array}$ & 0 & 0 & $\mathrm{O}$ & 0 & $\mathrm{O}$ \\
\hline $\begin{array}{l}\text { Insource : } \\
\text { Produce } \\
\text { internally or } \\
\text { vertical } \\
\text { integration (5) }\end{array}$ & 0 & 0 & $\mathrm{O}$ & 0 & 0 \\
\hline
\end{tabular}




\section{Q19h. Intellectual property crimes:}

In your opinion, how useful were these mitigation methods in preventing or limiting the negative impact on your supply chain of the intellectual property crimes (counterfeiting, copyright violations or hacking)?

\begin{tabular}{|c|c|c|c|c|c|}
\hline & $\begin{array}{c}\text { Not useful } \\
\text { at all (1) }\end{array}$ & $\begin{array}{c}\text { Somewhat } \\
\text { useful (2) }\end{array}$ & Useful (3) & $\begin{array}{l}\text { Very useful } \\
\text { (4) }\end{array}$ & $\begin{array}{c}\text { Not } \\
\text { applicable (5) }\end{array}$ \\
\hline $\begin{array}{l}\text { Buffering: } \\
\text { Inventory, } \\
\text { lead time or } \\
\text { capacity (1) }\end{array}$ & 0 & 0 & 0 & 0 & $\mathrm{O}$ \\
\hline $\begin{array}{l}\text { Redundancy: } \\
\text { Multiple } \\
\text { suppliers, } \\
\text { sites or } \\
\text { equipment (2) }\end{array}$ & $\mathrm{O}$ & 0 & 0 & 0 & O \\
\hline $\begin{array}{c}\text { Flexibility: } \\
\text { Quick } \\
\text { response or } \\
\text { change-overs } \\
\text { (3) }\end{array}$ & 0 & 0 & 0 & 0 & 0 \\
\hline $\begin{array}{l}\text { Visibility: } \\
\text { Collaboration } \\
\text { and timely } \\
\text { info from } \\
\text { supply chain } \\
\text { partners (4) }\end{array}$ & 0 & 0 & 0 & 0 & $\mathrm{O}$ \\
\hline $\begin{array}{l}\text { Insource : } \\
\text { Produce } \\
\text { internally or } \\
\text { vertical } \\
\text { integration (5) }\end{array}$ & 0 & 0 & 0 & 0 & 0 \\
\hline
\end{tabular}


Q19i. Corruption or bribery:

In your opinion, how useful were these mitigation methods in preventing or limiting the negative impact on your supply chain of the corruption or bribery?

\begin{tabular}{|c|c|c|c|c|c|}
\hline & $\begin{array}{l}\text { Not useful } \\
\text { at all (1) }\end{array}$ & $\begin{array}{l}\text { Somewhat } \\
\text { useful (2) }\end{array}$ & Useful (3) & $\begin{array}{l}\text { Very useful } \\
\text { (4) }\end{array}$ & $\begin{array}{c}\text { Not } \\
\text { applicable (5) }\end{array}$ \\
\hline $\begin{array}{l}\text { Buffering: } \\
\text { Inventory, } \\
\text { lead time or } \\
\text { capacity (1) }\end{array}$ & 0 & 0 & 0 & O & 0 \\
\hline $\begin{array}{l}\text { Redundancy: } \\
\text { Multiple } \\
\text { suppliers, } \\
\text { sites or } \\
\text { equipment (2) }\end{array}$ & O & $\mathrm{O}$ & 0 & O & $\mathrm{O}$ \\
\hline $\begin{array}{l}\text { Flexibility: } \\
\text { Quick } \\
\text { response or } \\
\text { change-overs } \\
\text { (3) }\end{array}$ & O & $\mathrm{O}$ & 0 & O & 0 \\
\hline $\begin{array}{l}\text { Visibility: } \\
\text { Collaboration } \\
\text { and timely } \\
\text { info from } \\
\text { supply chain } \\
\text { partners (4) }\end{array}$ & 0 & 0 & 0 & $\mathrm{O}$ & 0 \\
\hline $\begin{array}{l}\text { Insource : } \\
\text { Produce } \\
\text { internally or } \\
\text { vertical } \\
\text { integration (5) }\end{array}$ & O & 0 & 0 & 0 & $\mathrm{O}$ \\
\hline
\end{tabular}




\section{Q19j. Bureaucracy:}

In your opinion, how useful were these mitigation methods in preventing or limiting the negative impact on your supply chain of the bureaucracy (red tape, unclear, inconsistent restrictions or regulations)

\begin{tabular}{|c|c|c|c|c|c|}
\hline & $\begin{array}{c}\text { Not useful } \\
\text { at all (1) }\end{array}$ & $\begin{array}{c}\text { Somewhat } \\
\text { useful (2) }\end{array}$ & Useful (3) & $\begin{array}{l}\text { Very useful } \\
\text { (4) }\end{array}$ & $\begin{array}{c}\text { Not } \\
\text { applicable (5) }\end{array}$ \\
\hline $\begin{array}{l}\text { Buffering: } \\
\text { Inventory, } \\
\text { lead time or } \\
\text { capacity (1) }\end{array}$ & 0 & 0 & 0 & 0 & $\mathrm{O}$ \\
\hline $\begin{array}{l}\text { Redundancy: } \\
\text { Multiple } \\
\text { suppliers, } \\
\text { sites or } \\
\text { equipment (2) }\end{array}$ & $\mathrm{O}$ & 0 & 0 & 0 & O \\
\hline $\begin{array}{c}\text { Flexibility: } \\
\text { Quick } \\
\text { response or } \\
\text { change-overs } \\
\text { (3) }\end{array}$ & 0 & 0 & 0 & 0 & 0 \\
\hline $\begin{array}{l}\text { Visibility: } \\
\text { Collaboration } \\
\text { and timely } \\
\text { info from } \\
\text { supply chain } \\
\text { partners (4) }\end{array}$ & 0 & 0 & 0 & 0 & $\mathrm{O}$ \\
\hline $\begin{array}{l}\text { Insource: } \\
\text { Produce } \\
\text { internally or } \\
\text { vertical } \\
\text { integration (5) }\end{array}$ & 0 & 0 & 0 & 0 & 0 \\
\hline
\end{tabular}




\section{Q19k. Labor problems:}

In your opinion, how useful were these mitigation methods in preventing or limiting the negative impact on your supply chain of the labor problems (strikes, skills shortages, incompetence, turnover, or absenteeism)?

\begin{tabular}{|c|c|c|c|c|c|}
\hline & $\begin{array}{l}\text { Not useful } \\
\text { at all (1) }\end{array}$ & $\begin{array}{c}\text { Somewhat } \\
\text { useful (2) }\end{array}$ & Useful (3) & $\begin{array}{l}\text { Very useful } \\
\text { (4) }\end{array}$ & $\begin{array}{c}\text { Not } \\
\text { applicable (5) }\end{array}$ \\
\hline $\begin{array}{l}\text { Buffering: } \\
\text { Inventory, } \\
\text { lead time or } \\
\text { capacity (1) }\end{array}$ & 0 & 0 & 0 & 0 & O \\
\hline $\begin{array}{l}\text { Redundancy: } \\
\text { Multiple } \\
\text { suppliers, } \\
\text { sites or } \\
\text { equipment (2) }\end{array}$ & 0 & 0 & $\mathrm{O}$ & 0 & 0 \\
\hline $\begin{array}{l}\text { Flexibility: } \\
\text { Quick } \\
\text { response or } \\
\text { change-overs } \\
\text { (3) }\end{array}$ & O & $\mathrm{O}$ & $\mathrm{O}$ & 0 & 0 \\
\hline $\begin{array}{l}\text { Visibility: } \\
\text { Collaboration } \\
\text { and timely } \\
\text { info from } \\
\text { supply chain } \\
\text { partners (4) }\end{array}$ & 0 & 0 & 0 & 0 & 0 \\
\hline $\begin{array}{l}\text { Insource: } \\
\text { Produce } \\
\text { internally or } \\
\text { vertical } \\
\text { integration (5) }\end{array}$ & 0 & 0 & 0 & 0 & O \\
\hline
\end{tabular}




\section{Q19I. Tax system:}

In your opinion, how useful were these mitigation methods in preventing or limiting the negative impact on your supply chain of the tax system (burdensome, arbitrary or inconsistent)?

\begin{tabular}{|c|c|c|c|c|c|}
\hline & $\begin{array}{l}\text { Not useful } \\
\text { at all (1) }\end{array}$ & $\begin{array}{l}\text { Somewhat } \\
\text { useful (2) }\end{array}$ & Useful (3) & $\begin{array}{l}\text { Very useful } \\
\text { (4) }\end{array}$ & $\begin{array}{c}\text { Not } \\
\text { applicable (5) }\end{array}$ \\
\hline $\begin{array}{l}\text { Buffering: } \\
\text { Inventory, } \\
\text { lead time or } \\
\text { capacity (1) }\end{array}$ & 0 & $\mathrm{O}$ & 0 & 0 & O \\
\hline $\begin{array}{l}\text { Redundancy: } \\
\text { Multiple } \\
\text { suppliers, } \\
\text { sites or } \\
\text { equipment (2) }\end{array}$ & $\mathrm{O}$ & O & 0 & O & O \\
\hline $\begin{array}{c}\text { Flexibility: } \\
\text { Quick } \\
\text { response or } \\
\text { change-overs } \\
\text { (3) }\end{array}$ & $\mathrm{O}$ & O & 0 & 0 & 0 \\
\hline $\begin{array}{l}\text { Visibility: } \\
\text { Collaboration } \\
\text { and timely } \\
\text { info from } \\
\text { supply chain } \\
\text { partners (4) }\end{array}$ & 0 & $\mathrm{O}$ & 0 & 0 & O \\
\hline $\begin{array}{l}\text { Insource : } \\
\text { Produce } \\
\text { internally or } \\
\text { vertical } \\
\text { integration (5) }\end{array}$ & 0 & 0 & 0 & 0 & 0 \\
\hline
\end{tabular}




\section{Q19m. Supplier problems:}

In your opinion, how useful were these mitigation methods in preventing or limiting the negative impact on your supply chain of the supplier problems (quality, reliability, timeliness or financial strength)?

\begin{tabular}{|c|c|c|c|c|c|}
\hline & $\begin{array}{l}\text { Not useful } \\
\text { at all (1) }\end{array}$ & $\begin{array}{l}\text { Somewhat } \\
\text { useful (2) }\end{array}$ & Useful (3) & $\begin{array}{l}\text { Very useful } \\
\text { (4) }\end{array}$ & $\begin{array}{c}\text { Not } \\
\text { applicable (5) }\end{array}$ \\
\hline $\begin{array}{l}\text { Buffering: } \\
\text { Inventory, } \\
\text { lead time or } \\
\text { capacity (1) }\end{array}$ & 0 & 0 & 0 & 0 & 0 \\
\hline $\begin{array}{l}\text { Redundancy: } \\
\text { Multiple } \\
\text { suppliers, } \\
\text { sites or } \\
\text { equipment (2) }\end{array}$ & O & $\mathrm{O}$ & O & 0 & 0 \\
\hline $\begin{array}{l}\text { Flexibility: } \\
\text { Quick } \\
\text { response or } \\
\text { change-overs } \\
\text { (3) }\end{array}$ & $\mathrm{O}$ & $\mathrm{O}$ & 0 & 0 & 0 \\
\hline $\begin{array}{l}\text { Visibility: } \\
\text { Collaboration } \\
\text { and timely } \\
\text { info from } \\
\text { supply chain } \\
\text { partners (4) }\end{array}$ & 0 & 0 & 0 & 0 & 0 \\
\hline $\begin{array}{l}\text { Insource : } \\
\text { Produce } \\
\text { internally or } \\
\text { vertical } \\
\text { integration (5) }\end{array}$ & 0 & 0 & O & 0 & 0 \\
\hline
\end{tabular}




\section{Q19n. Other 1:}

In your opinion, how useful were these mitigation methods in preventing or limiting the negative impact on your supply chain of the Other 1 problem?

\begin{tabular}{|c|c|c|c|c|c|}
\hline & $\begin{array}{c}\text { Not useful } \\
\text { at all (1) }\end{array}$ & $\begin{array}{c}\text { Somewhat } \\
\text { useful (2) }\end{array}$ & Useful (3) & $\begin{array}{l}\text { Very useful } \\
\text { (4) }\end{array}$ & $\begin{array}{c}\text { Not } \\
\text { applicable (5) }\end{array}$ \\
\hline $\begin{array}{l}\text { Buffering: } \\
\text { Inventory, } \\
\text { lead time or } \\
\text { capacity (1) }\end{array}$ & $\mathrm{O}$ & 0 & 0 & 0 & 0 \\
\hline $\begin{array}{l}\text { Redundancy: } \\
\text { Multiple } \\
\text { suppliers, } \\
\text { sites or } \\
\text { equipment (2) }\end{array}$ & O & $\mathrm{O}$ & 0 & $\mathrm{O}$ & $\mathrm{O}$ \\
\hline $\begin{array}{l}\text { Flexibility: } \\
\text { Quick } \\
\text { response or } \\
\text { change-overs } \\
\text { (3) }\end{array}$ & O & $\mathrm{O}$ & 0 & O & 0 \\
\hline $\begin{array}{l}\text { Visibility: } \\
\text { Collaboration } \\
\text { and timely } \\
\text { info from } \\
\text { supply chain } \\
\text { partners (4) }\end{array}$ & 0 & 0 & 0 & 0 & 0 \\
\hline $\begin{array}{l}\text { Insource : } \\
\text { Produce } \\
\text { internally or } \\
\text { vertical } \\
\text { integration (5) }\end{array}$ & 0 & 0 & 0 & $\mathrm{O}$ & 0 \\
\hline
\end{tabular}




\section{Q19o. Other 2:}

In your opinion, how useful were these mitigation methods in preventing or limiting the negative impact on your supply chain of the Other 2 problem?

\begin{tabular}{|c|c|c|c|c|c|}
\hline & $\begin{array}{l}\text { Not useful } \\
\text { at all (1) }\end{array}$ & $\begin{array}{c}\text { Somewhat } \\
\text { useful (2) }\end{array}$ & Useful (3) & $\begin{array}{l}\text { Very useful } \\
\text { (4) }\end{array}$ & $\begin{array}{c}\text { Not } \\
\text { applicable (5) }\end{array}$ \\
\hline $\begin{array}{l}\text { Buffering: } \\
\text { Inventory, } \\
\text { lead time or } \\
\text { capacity (1) }\end{array}$ & $\mathrm{O}$ & O & $\mathrm{O}$ & 0 & O \\
\hline $\begin{array}{l}\text { Redundancy: } \\
\text { Multiple } \\
\text { suppliers, } \\
\text { sites or } \\
\text { equipment (2) }\end{array}$ & 0 & O & O & O & O \\
\hline $\begin{array}{l}\text { Flexibility: } \\
\text { Quick } \\
\text { response or } \\
\text { change-overs } \\
\text { (3) }\end{array}$ & 0 & O & 0 & 0 & O \\
\hline $\begin{array}{l}\text { Visibility: } \\
\text { Collaboration } \\
\text { and timely } \\
\text { info from } \\
\text { supply chain } \\
\text { partners (4) }\end{array}$ & 0 & $\mathrm{O}$ & 0 & $\mathrm{O}$ & $\mathrm{O}$ \\
\hline $\begin{array}{l}\text { Insource : } \\
\text { Produce } \\
\text { internally or } \\
\text { vertical } \\
\text { integration (5) }\end{array}$ & $\mathrm{O}$ & 0 & 0 & O & O \\
\hline
\end{tabular}




\begin{tabular}{|c|c|c|c|c|}
\hline $\begin{array}{l}\text { Q20. Lastly, how frequently do you } \\
\text { expect the following disruptions will } \\
\text { affect your supply chain in India over } \\
\text { the next three years (as compared to } \\
\text { the previous three years)? }\end{array}$ & $\begin{array}{c}\text { Don't } \\
\text { expect it } \\
\text { to affect } \\
\text { our } \\
\text { supply } \\
\text { chain (1) }\end{array}$ & $\begin{array}{l}\text { Less } \\
\text { frequent } \\
\text { than } \\
\text { previously } \\
\text { (2) }\end{array}$ & $\begin{array}{l}\text { Same } \\
\text { frequency } \\
\text { as } \\
\text { previously } \\
\text { (3) }\end{array}$ & $\begin{array}{l}\text { More } \\
\text { frequent } \\
\text { than } \\
\text { previously } \\
\text { (4) }\end{array}$ \\
\hline $\begin{array}{l}\text { Flooding (incl. weather related events) } \\
\text { (1) }\end{array}$ & $\mathrm{O}$ & O & O & O \\
\hline $\begin{array}{l}\text { Major accidents (incl. fires, explosions, } \\
\text { structural collapses, or spills) (2) }\end{array}$ & O & O & O & O \\
\hline Terrorism, riots, or civil unrest (3) & O & $\mathrm{O}$ & $\mathrm{O}$ & $\mathrm{O}$ \\
\hline $\begin{array}{l}\text { Inadequate or slow transportation } \\
\text { infrastructure (road, rail, ports, or air) } \\
\text { (4) }\end{array}$ & O & $\mathrm{O}$ & $\mathrm{O}$ & $\mathrm{O}$ \\
\hline $\begin{array}{l}\text { Inadequate logistics infrastructure } \\
\text { (distribution, warehousing, or cold } \\
\text { storage) (5) }\end{array}$ & $\mathrm{O}$ & $\mathrm{O}$ & O & O \\
\hline $\begin{array}{l}\text { Inadequate utilities infrastructure } \\
\text { (electricity, water, sewer, telephone, } \\
\text { or internet) (6) }\end{array}$ & $\mathrm{O}$ & O & O & O \\
\hline $\begin{array}{l}\text { Property or violent crimes (theft, } \\
\text { robbery, hijackings, vandalism, } \\
\text { computer viruses or fraud) (7) }\end{array}$ & $\mathrm{O}$ & O & O & O \\
\hline $\begin{array}{l}\text { Intellectual property crimes } \\
\text { (counterfeiting, copyright violations, or } \\
\text { hacking) (8) }\end{array}$ & $\mathrm{O}$ & $\mathrm{O}$ & $\mathrm{O}$ & $\mathrm{O}$ \\
\hline
\end{tabular}




\begin{tabular}{|c|c|c|c|c|}
\hline Corruption or bribery (9) & $\mathrm{O}$ & $\mathrm{O}$ & $\mathrm{O}$ & $\mathrm{O}$ \\
\hline $\begin{array}{l}\text { Bureaucracy (red tape, unclear, } \\
\text { inconsistent restrictions, or } \\
\text { regulations) (10) }\end{array}$ & $\mathrm{O}$ & $\mathrm{O}$ & $\mathrm{O}$ & $\mathrm{O}$ \\
\hline $\begin{array}{l}\text { Labor problems (strikes, skills } \\
\text { shortages, incompetence, turnover, or } \\
\text { absenteeism) (11) }\end{array}$ & $\mathrm{O}$ & O & ○ & $\mathrm{O}$ \\
\hline $\begin{array}{c}\text { Tax system (burdensome, arbitrary, or } \\
\text { inconsistent) (12) }\end{array}$ & $\mathrm{O}$ & $\mathrm{O}$ & $\mathrm{O}$ & $\mathrm{O}$ \\
\hline $\begin{array}{l}\text { Supplier problems (quality, reliability, } \\
\text { timeliness, or financial strength) (13) }\end{array}$ & O & O & $\mathrm{O}$ & $\mathrm{O}$ \\
\hline Other 1 (14) & $\mathrm{O}$ & $\mathrm{O}$ & $\mathrm{O}$ & $\mathrm{O}$ \\
\hline Other 2 (15) & O & $\mathrm{O}$ & O & $\mathrm{O}$ \\
\hline $\begin{array}{l}\text { Any other disruption you expect? } \\
\text { (write in) }\end{array}$ & O & 0 & $\mathrm{O}$ & 0 \\
\hline (16) & & & & \\
\hline
\end{tabular}


Q21. OPTIONAL: Any other observations or comments you would like to add regarding supply chain disruptions in India?

Thank you very much! That completes this survey. If you would like a summary report of the aggregate results, please e-mail us at udbye@pdx.edu and request a copy. Any other feedback would also be appreciated. 


\section{APPENDIX B: SUPPORTING INFORMATION ON NATURAL DISASTERS IN INDIA}

\section{Table 38: EXAMPLES OF FREQUENT SUPPLY CHAIN RISKS IN INDIA}

\begin{tabular}{|c|c|c|}
\hline $\begin{array}{l}\text { Type of } \\
\text { disruption }\end{array}$ & Description & Source \\
\hline $\begin{array}{l}\text { Tropical } \\
\text { cyclones }\end{array}$ & $\begin{array}{l}\text { Of the } 30 \text { deadliest tropical cyclones in world } \\
\text { history, } 22 \text { happened in the Bay of Bengal and } \\
\text { affected India, Bangladesh and Myanmar, killing } \\
\text { about } 2.5 \text { million people }\end{array}$ & $\begin{array}{l}\text { Weather Underground: } \\
\text { www.wunderground.co } \\
\text { m/hurricane/deadlyworl } \\
\text { d.asp } \\
\text { (Tatham, Oloruntoba, \& } \\
\text { Spens, 2012) }\end{array}$ \\
\hline Power outages & $\begin{array}{l}\text { In one of the world's worst power blackouts ever, } \\
\text { more than } 600 \text { million people across India lost } \\
\text { electricity July 31, 2012, the second massive grid } \\
\text { failure in two days. }\end{array}$ & $\begin{array}{l}\text { (Lavelle, Smith, \& Byerly, } \\
\text { 2012) }\end{array}$ \\
\hline Earthquakes & $\begin{array}{l}\text { Between } 1960 \text { and } 2007, \text { India registered } 209 \\
\text { earthquakes with a magnitude between } 4.5 \text { and } \\
7.6 \text {, causing } 20,023 \text { deaths, } 5 \text { landslides, } 1 \\
\text { tsunami and temporarily displaced almost } 50 \\
\text { million people. }{ }^{131}\end{array}$ & $\begin{array}{l}\text { EXPO-CAT_2007: } \\
\text { http://earthquake.usgs.g } \\
\text { ov/research/data/pager/ } \\
\end{array}$ \\
\hline Flooding & $\begin{array}{l}\text { During late summer and early fall of } 2011 \text {, there } \\
\text { were four major floods caused by heavy rains in } \\
\text { the states of Uttar Pradesh, Uttarakhand, West } \\
\text { Bengal, Orissa and Bihar. These killed } 240 \text { people, } \\
\text { destroyed several hundred thousand houses, } \\
\text { damaged croplands, and caused registered } \\
\text { damage for more than } \$ 1.2 \text { billion }\end{array}$ & (Swiss-Re, 2012) \\
\hline Draught & $\begin{array}{l}\text { Huge areas of India are undergoing sustained } \\
\text { draught, with a significant impact on agricultural } \\
\text { outputs. This may shave } 0.5 \% \text { off the country's } \\
\text { GDP, or about } \$ 8.4 \text { billion. }\end{array}$ & (Maplecroft, 2012a) \\
\hline Terrorism & $\begin{array}{l}\text { The two most serious recent attacks happened in } \\
\text { Mumbai in July of } 2006 \text { and November of } 2008 \text {, } \\
\text { when Islamic militants targeted public } \\
\text { transportation and hotels, killing } 187 \text { and } 183 \\
\text { people, respectively. The Indian rail system seems } \\
\text { to be a popular target for extremists, with several } \\
\text { attacks over the past } 20 \text { years. }\end{array}$ & $\begin{array}{l}\text { (Global_Integrity, 2012; } \\
\text { IFEP, 2012) }\end{array}$ \\
\hline
\end{tabular}

${ }^{131}$ This is a lot less than China, which tends to have more, stronger and much deadlier earthquakes. 
Table 39: SUMMARY OF INDIAN NATURAL DISASTERS FROM 1900 TO $2012^{132}$

\begin{tabular}{|c|c|c|c|c|c|}
\hline Type & Sub-type & $\begin{array}{l}\text { \# of } \\
\text { events }\end{array}$ & $\begin{array}{l}\text { Killed total } \\
\text { \& average }\end{array}$ & $\begin{array}{l}\text { Total affected } \\
\& \text { average }\end{array}$ & $\begin{array}{l}\text { Damage total } \\
\text { \& average }\end{array}$ \\
\hline Drought & Drought & 14 & $\begin{array}{l}4,250,320 \\
303,594\end{array}$ & $\begin{array}{l}1,061,841,000 \\
75,845,786\end{array}$ & $\begin{array}{l}\$ 2,441,122,000 \\
\$ 174,366,000\end{array}$ \\
\hline \multirow[t]{2}{*}{$\begin{array}{l}\text { Seismic } \\
\text { activity }\end{array}$} & Earthquake & 26 & $\begin{array}{l}61,817 \\
2,378\end{array}$ & $\begin{array}{l}27,840,383 \\
1,070,784\end{array}$ & $\begin{array}{l}\$ 4,079,900,000 \\
\$ 156,919,000\end{array}$ \\
\hline & Tsunami $^{133}$ & 1 & $\begin{array}{l}16,389 \\
16,389 \\
\end{array}$ & $\begin{array}{l}654,512 \\
654,512\end{array}$ & $\begin{array}{l}\$ 1,022,800,000 \\
\$ 1,022,800,000\end{array}$ \\
\hline \multirow[t]{4}{*}{ Epidemic } & Unspecified & 6 & $\begin{array}{l}293 \\
49 \\
\end{array}$ & $\begin{array}{l}95,997 \\
16,000\end{array}$ & - \\
\hline & $\begin{array}{l}\text { Bacterial } \\
\text { infectious } \\
\text { diseases }\end{array}$ & 24 & $\begin{array}{l}4,103,948 \\
170,998\end{array}$ & $\begin{array}{l}70,856 \\
2,952\end{array}$ & - \\
\hline & $\begin{array}{l}\text { Parasitic } \\
\text { infectious } \\
\text { diseases }\end{array}$ & 5 & $\begin{array}{l}3,411 \\
682\end{array}$ & $\begin{array}{l}57,135 \\
11,427\end{array}$ & - \\
\hline & $\begin{array}{l}\text { Viral infect. } \\
\text { diseases }\end{array}$ & 33 & $\begin{array}{l}436,222 \\
13,219 \\
\end{array}$ & $\begin{array}{l}197,485 \\
5,984\end{array}$ & - \\
\hline \multirow[t]{3}{*}{$\begin{array}{l}\text { Extreme } \\
\text { temperature }\end{array}$} & Cold wave & 26 & $\begin{array}{l}4,979 \\
192\end{array}$ & $\begin{array}{l}25 \\
1 \\
\end{array}$ & $\begin{array}{l}\$ 144,000,000 \\
\$ 5,539,000\end{array}$ \\
\hline & $\begin{array}{l}\text { Extreme } \\
\text { winter cond }\end{array}$ & 1 & $\begin{array}{l}180 \\
180\end{array}$ & - & - \\
\hline & Heat wave & 23 & $\begin{array}{l}8,869 \\
386\end{array}$ & $\begin{array}{l}225 \\
10 \\
\end{array}$ & $\begin{array}{l}\$ 400,000,000 \\
\$ 17,391,000\end{array}$ \\
\hline \multirow[t]{4}{*}{ Flood } & Unspecified & 93 & $\begin{array}{l}30,536 \\
328\end{array}$ & $\begin{array}{l}455,269,954 \\
4,896,375\end{array}$ & $\begin{array}{l}\$ 11,673,059,000 \\
\$ 125,517,000\end{array}$ \\
\hline & Flash flood & 22 & $\begin{array}{l}7,419 \\
337\end{array}$ & $\begin{array}{l}23,431,206 \\
1,065,055\end{array}$ & $\begin{array}{l}\$ 416,200,000 \\
\$ 18,918,000\end{array}$ \\
\hline & $\begin{array}{l}\text { General } \\
\text { flood }\end{array}$ & 125 & $\begin{array}{l}22,471 \\
180 \\
\end{array}$ & $\begin{array}{l}323,180,129 \\
2,585,441 \\
\end{array}$ & $\begin{array}{l}\$ 23,437,929,000 \\
\$ 187,503,000\end{array}$ \\
\hline & $\begin{array}{l}\text { Stormsurge, } \\
\text { coast flood }\end{array}$ & 4 & $\begin{array}{l}569 \\
142 \\
\end{array}$ & $\begin{array}{l}11,500,000 \\
2,875,000 \\
\end{array}$ & $\begin{array}{l}\$ 275,000,000 \\
\$ 68,750,000\end{array}$ \\
\hline Insect infest. & Locusts & 1 & & & \\
\hline \multirow[t]{2}{*}{$\begin{array}{l}\text { Dry mass } \\
\text { movement }\end{array}$} & Avalanche & 1 & $\begin{array}{l}12 \\
12\end{array}$ & & \\
\hline & Landslide & 1 & $\begin{array}{l}45 \\
45 \\
\end{array}$ & & \\
\hline
\end{tabular}

${ }^{132}$ To qualify as a disaster, at least one of the following criteria has to be fulfilled: 10 or more people reported killed; 100 or more people reported affected; a call for international assistance; declaration of a state of emergency.

${ }^{133}$ This is the Indian Ocean tsunami around Christmas 2004 that was caused by an earthquake off Sumatra and killed more than 220,000 people in total. It hit the Indian east coast hard (Perry, 2007) 


\begin{tabular}{|c|c|c|c|c|c|}
\hline \multirow[t]{2}{*}{$\begin{array}{l}\text { Wet mass } \\
\text { movement }\end{array}$} & Avalanche & 7 & $\begin{array}{l}828 \\
118\end{array}$ & $\begin{array}{l}10,456 \\
1,494 \\
\end{array}$ & $\begin{array}{l}\$ 50,000,000 \\
\$ 7,143,000\end{array}$ \\
\hline & Landslide & 35 & $\begin{array}{l}3,934 \\
112 \\
\end{array}$ & $\begin{array}{l}3,828,660 \\
109,390 \\
\end{array}$ & $\begin{array}{l}\$ 4,500,000 \\
\$ 129,000\end{array}$ \\
\hline \multirow[t]{3}{*}{ Storm } & Unspecified & 32 & $\begin{array}{l}2,702 \\
84 \\
\end{array}$ & $\begin{array}{l}5,337,261 \\
166,789 \\
\end{array}$ & $\begin{array}{l}\$ 225,000,000 \\
\$ 7,031,000\end{array}$ \\
\hline & Local storm & 27 & $\begin{array}{l}2,406 \\
89\end{array}$ & $\begin{array}{l}565,175 \\
20,932 \\
\end{array}$ & $\begin{array}{l}\$ 2,226,000,000 \\
\$ 82,444,000\end{array}$ \\
\hline & $\begin{array}{l}\text { Tropical } \\
\text { cyclone }^{134}\end{array}$ & 98 & $\begin{array}{l}159,177 \\
1,624 \\
\end{array}$ & $\begin{array}{l}87,642,126 \\
894,307\end{array}$ & $\begin{array}{l}\$ 8,976,525,000 \\
\$ 91,597,000\end{array}$ \\
\hline Wildfire & Forest fire & 2 & $\begin{array}{l}6 \\
3 \\
\end{array}$ & & $\begin{array}{l}\$ 2,000,000 \\
\$ 1,000,000\end{array}$ \\
\hline
\end{tabular}

Source: (EM-DAT, 2012)

Table 40: IMPACTS OF NATURAL DISASTERS BY REGION, 1975 - 2011

\begin{tabular}{|c|c|c|c|c|c|c|}
\hline Region & $\begin{array}{l}\text { Popula- } \\
\text { tion }\end{array}$ & $\begin{array}{l}\text { Popul. } \\
\text { density } \\
\text { per km² }\end{array}$ & $\begin{array}{l}\text { Occur- } \\
\text { rences } \\
\text { (share in \%) }\end{array}$ & $\begin{array}{l}\text { Killed } \\
\text { (share in } \\
\% \text { ) }\end{array}$ & $\begin{array}{l}\text { Affected } \\
\text { (share in \%) }\end{array}$ & $\begin{array}{l}\text { Damage } \\
\text { US\$ million } \\
\text { (share \%) }\end{array}$ \\
\hline Africa & $\begin{array}{l}1,033 \\
\text { mill. }\end{array}$ & 30.5 & $\begin{array}{l}2,057 \\
(19.6 \%)\end{array}$ & $\begin{array}{l}728,621 \\
(25.5 \%)\end{array}$ & $\begin{array}{l}393,800,705 \\
(6.5 \%)\end{array}$ & $\begin{array}{l}\$ 27,308 \\
(1.2 \%)\end{array}$ \\
\hline Americas & 911 mill. & 42.5 & $\begin{array}{l}2,498 \\
(23.8 \%)\end{array}$ & $\begin{array}{l}418,484 \\
(14.6 \%)\end{array}$ & $\begin{array}{l}210,406,943 \\
(3.5 \%)\end{array}$ & $\begin{array}{l}\$ 757,763 \\
(33.9 \%)\end{array}$ \\
\hline Asia & $\begin{array}{l}3,879 \\
\text { mill. }\end{array}$ & 87 & $\begin{array}{l}4,041 \\
(38.6 \%)\end{array}$ & $\begin{array}{l}1,521,599 \\
(53.3 \%)\end{array}$ & $\begin{array}{l}5,402,771,764 \\
(89.0 \%)\end{array}$ & $\begin{array}{l}\$ 1,086,756 \\
(48.7 \%)\end{array}$ \\
\hline Europe & 739 mill. & 10.2 & $\begin{array}{l}1,390 \\
(13.3 \%)\end{array}$ & $\begin{array}{l}182,721 \\
(6.4 \%)\end{array}$ & $\begin{array}{l}42,065,797 \\
(0.7 \%)\end{array}$ & $\begin{array}{l}306,022 \\
(13.7 \%)\end{array}$ \\
\hline Oceania & 36 mill. & 4.2 & $\begin{array}{l}489 \\
(4.7 \%)\end{array}$ & $\begin{array}{l}5,999 \\
(0.2 \%)\end{array}$ & $\begin{array}{l}20,552,254 \\
(0.3 \%)\end{array}$ & $\begin{array}{l}55,801 \\
(2.5 \%)\end{array}$ \\
\hline TOTAL & & & $\begin{array}{l}10,473 \\
(100 \%)\end{array}$ & $\begin{array}{l}2,857,424 \\
(100 \%)\end{array}$ & $\begin{array}{l}6,069,597,463 \\
(100 \%)\end{array}$ & $\begin{array}{l}\$ 2,233,649 \\
(100 \%)\end{array}$ \\
\hline
\end{tabular}

Source: (Asian_Disaster_Reduction_Center, 2012)

${ }^{134}$ The ability to forecast tropical cyclones (their path and point of landing) is much better now than previously. According to the World Meteorological Organization, the 3 days forecasts are now as good as were the 48 hour forecasts just a few years ago (WMO, 2012). This has significant positive consequences for supply chain risk management and preparation. 
Figure 2: EARTHQUAKE FREQUENCIES IN ASIA: INDIA NOT PART OF THE RING OF FIRE

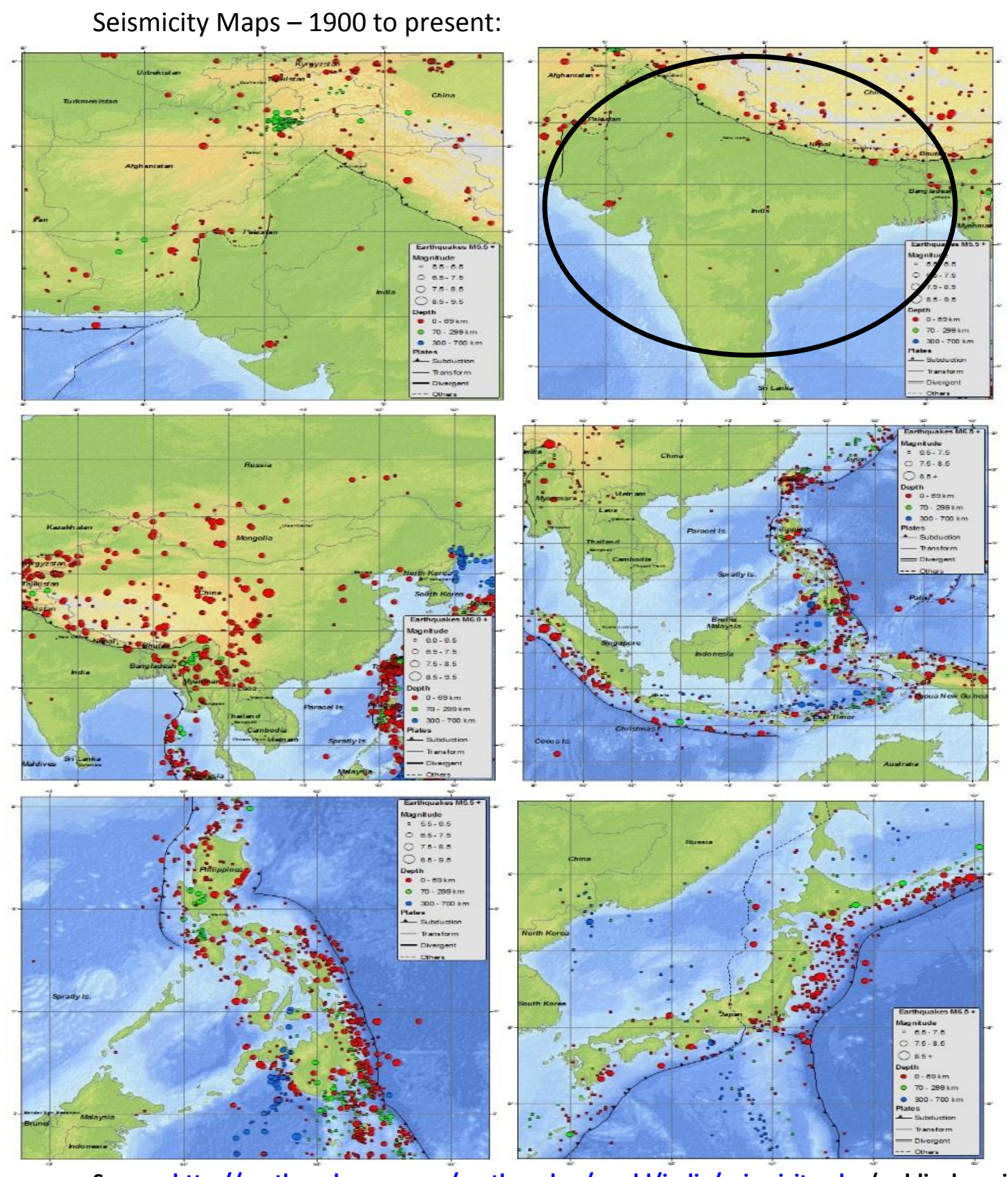

Source: http://earthquake.usgs.gov/earthquakes/world/india/seismicity.php (public domain)

The red dots indicate occurrences of earthquakes 
Figure 3: INDIA CLIMATIC DISASTERS RISK MAP

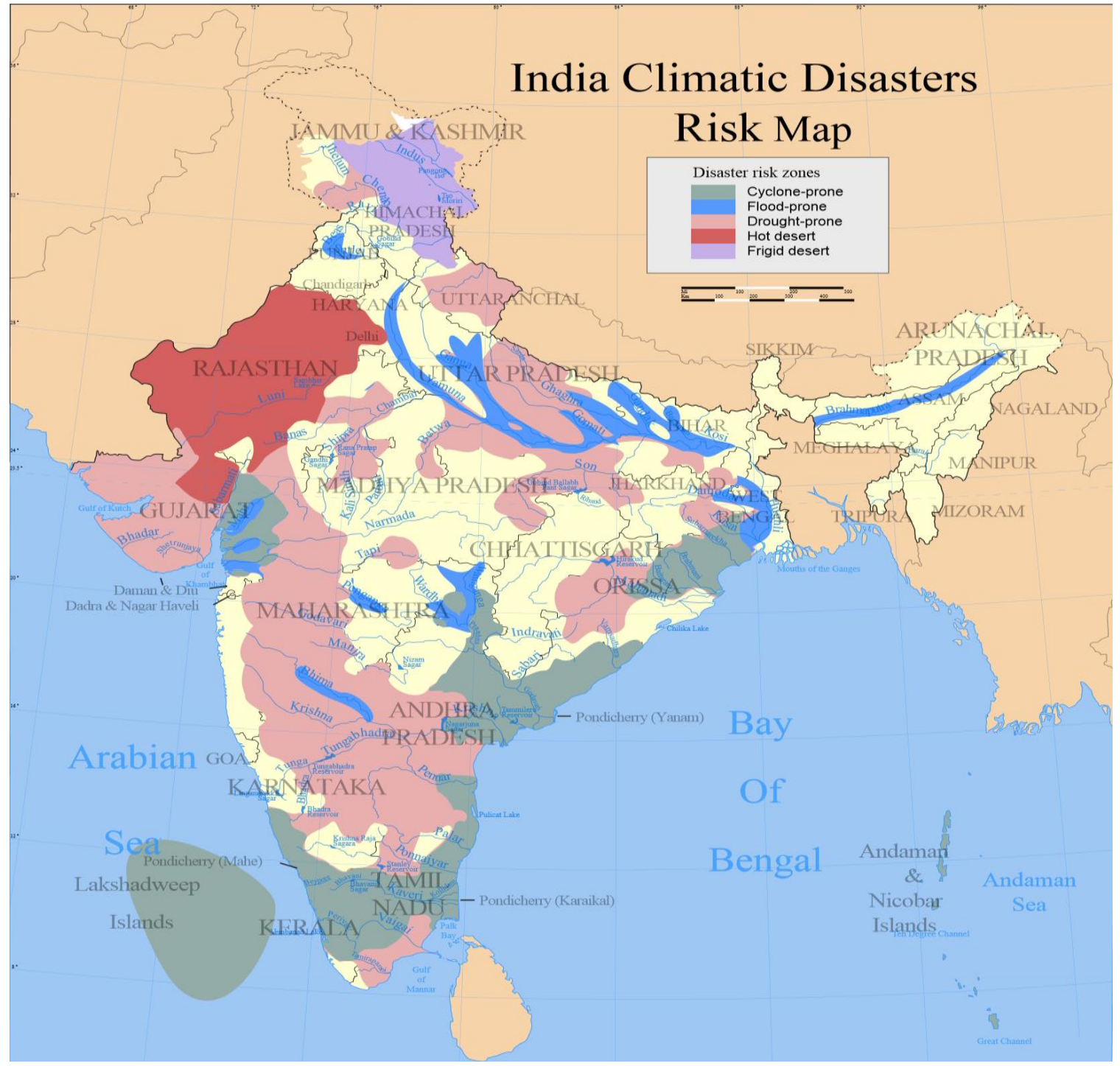

Source:

http://upload.wikimedia.org/wikipedia/commons/3/35/India climatic disaster risk map en.svg 
An alternative typology of natural disasters is provided by USAID and CRED

(Guha-Sapir et al., 2012). They divide events into five subgroups of disasters ${ }^{135}$ :

Table 41: SUBGROUPS OF NATURAL DISASTERS

\begin{tabular}{|l|l|l|}
\hline Disaster Subgroup & Definition & $\begin{array}{l}\text { Disaster main types and } \\
\text { examples }\end{array}$ \\
\hline Geophysical & $\begin{array}{l}\text { Events originating from solid } \\
\text { earth }\end{array}$ & $\begin{array}{l}\text { Earthquake, volcano, dry } \\
\text { mass movement }\end{array}$ \\
\hline Meteorological & $\begin{array}{l}\text { Events caused by short- } \\
\text { lived/small to meso scale } \\
\text { atmospheric processes (in } \\
\text { the spectrum from minutes } \\
\text { to days) }\end{array}$ & Storm \\
\hline Hydrological & $\begin{array}{l}\text { Events caused by deviations } \\
\text { in the normal water cycle } \\
\text { and/or overflow of bodies of } \\
\text { water caused by wind set-up }\end{array}$ & Flood, wet mass movement \\
\hline Climatological & $\begin{array}{l}\text { Events caused by long- } \\
\text { lived/meso to macro scale } \\
\text { processes (in the spectrum } \\
\text { from intra-seasonal to multi- } \\
\text { decadal climate variability) }\end{array}$ & $\begin{array}{l}\text { Extreme temperature, } \\
\text { drought, wildfire }\end{array}$ \\
\hline Biological & $\begin{array}{l}\text { Disaster caused by the } \\
\text { exposure of living organisms } \\
\text { to germs and toxic } \\
\text { substances. }\end{array}$ & Epidemic, insect infestation, \\
animal stampede
\end{tabular}

135 CRED defines a disaster as "a situation or event which overwhelms local capacity, necessitating a request to a national or international level for external assistance; an unforeseen and often sudden event that causes great damage, destruction and human suffering". Such an event is obviously in a different league than a freight pallet tipping over. A broader definition provided in Webster's dictionary may also be instructive: "a sudden or great misfortune" (Merriam-Webster, 1976). In supply chain management we are concerned with disruptive and costly events, making both natural disasters and various mishaps events of interest to us. 
APPENDIX C: SUPPORTING INFORMATION ON MANMADE DISASTERS IN INDIA

Table 42: SUMMARY OF INDIAN TECHNOLOGICAL DISASTERS FROM 1900 TO 2012

\begin{tabular}{|c|c|c|c|c|c|}
\hline Type & Sub-type & $\begin{array}{l}\text { \# of } \\
\text { events }\end{array}$ & $\begin{array}{l}\text { Killed total } \\
\& \text { average }\end{array}$ & $\begin{array}{l}\text { Total affected } \\
\text { \& average }\end{array}$ & $\begin{array}{l}\text { Damage total } \\
\& \text { average }\end{array}$ \\
\hline \multirow[t]{7}{*}{$\begin{array}{l}\text { Industrial } \\
\text { accident }\end{array}$} & $\begin{array}{l}\text { Chemical } \\
\text { spill }\end{array}$ & 2 & $\begin{array}{l}2 \\
1\end{array}$ & $\begin{array}{l}100,460 \\
50,230\end{array}$ & - \\
\hline & Collapse & 9 & $\begin{array}{l}203 \\
23\end{array}$ & $\begin{array}{l}11 \\
1\end{array}$ & - \\
\hline & Explosion & 39 & $\begin{array}{l}2,075 \\
53\end{array}$ & $\begin{array}{l}4,913 \\
126\end{array}$ & $\begin{array}{l}\$ 228,000,000 \\
\$ 5,836,000\end{array}$ \\
\hline & Fire & 19 & $\begin{array}{l}381 \\
20\end{array}$ & $\begin{array}{l}126,596 \\
6,663\end{array}$ & $\begin{array}{l}\$ 470,900,000 \\
\$ 24,784\end{array}$ \\
\hline & Gas leak & 3 & $\begin{array}{l}2,500 \\
833\end{array}$ & $\begin{array}{l}300,751 \\
100,250\end{array}$ & - \\
\hline & Other & 7 & $\begin{array}{l}164 \\
23\end{array}$ & & \\
\hline & Poisoning & 14 & $\begin{array}{l}980 \\
70\end{array}$ & $\begin{array}{l}1,743 \\
125\end{array}$ & \\
\hline \multirow[t]{4}{*}{$\begin{array}{l}\text { Misc. } \\
\text { accidents }\end{array}$} & Collapse & 40 & $\begin{array}{l}2,798 \\
70\end{array}$ & $\begin{array}{l}151,103 \\
3,778\end{array}$ & $\begin{array}{l}\$ 10,000,000 \\
\$ 250,000\end{array}$ \\
\hline & Explosion & 10 & $\begin{array}{l}301 \\
30\end{array}$ & $\begin{array}{l}214 \\
21\end{array}$ & - \\
\hline & Fire & 33 & $\begin{array}{l}1,636 \\
50\end{array}$ & $\begin{array}{l}63,667 \\
1,929\end{array}$ & - \\
\hline & Other & 26 & $\begin{array}{l}1,733 \\
67\end{array}$ & $\begin{array}{l}6,187 \\
238\end{array}$ & - \\
\hline \multirow[t]{4}{*}{$\begin{array}{l}\text { Transport } \\
\text { accident }\end{array}$} & Air & 22 & $\begin{array}{l}1,415 \\
64\end{array}$ & $\begin{array}{l}101 \\
5\end{array}$ & $\begin{array}{l}\$ 36,000,000 \\
\$ 1,636,000\end{array}$ \\
\hline & Rail & 111 & $\begin{array}{l}4,694 \\
42\end{array}$ & $\begin{array}{l}6,664 \\
60\end{array}$ & $\begin{array}{l}\$ 2,000,000 \\
\$ 18,000\end{array}$ \\
\hline & Road & 242 & $\begin{array}{l}8,241 \\
34\end{array}$ & $\begin{array}{l}3,578 \\
15\end{array}$ & - \\
\hline & Water & 81 & $\begin{array}{l}4,958 \\
61\end{array}$ & $\begin{array}{l}354 \\
4\end{array}$ & - \\
\hline
\end{tabular}

Source: (EM-DAT, 2012) 
Table 43: 2011: A TYPICAL YEAR IN INDIA?

(as tabulated by the insurer Swiss Re, (Swiss-Re, 2012))

\begin{tabular}{|c|c|c|c|}
\hline When & Place & Event & $\begin{array}{l}\text { No. of } \\
\text { victims/amount of } \\
\text { damage in US\$ }\end{array}$ \\
\hline \multicolumn{4}{|c|}{ 1) Natural Disasters } \\
\hline June-July & $\begin{array}{l}\text { Uttar Pradesh, } \\
\text { Uttarakhand }\end{array}$ & $\begin{array}{l}\text { Floods caused by heavy } \\
\text { monsoon rains }\end{array}$ & $\begin{array}{l}50 \text { dead } \\
\$ 20 \text { mill. damage }\end{array}$ \\
\hline August & West Bengal & $\begin{array}{l}\text { Floods caused by heavy rains; } \\
\text { several rivers burst their banks; } \\
\text { damage to houses and croplands }\end{array}$ & $\begin{array}{l}100 \text { dead } \\
\$ 239 \text { mill. damage }\end{array}$ \\
\hline September & Orissa & $\begin{array}{l}\text { Floods caused by heavy rains; } \\
\text { over } 100,000 \text { houses destroyed }\end{array}$ & $\begin{array}{l}39 \text { dead } \\
\$ 430 \text { mill. damage }\end{array}$ \\
\hline Sept. - Oct. & $\begin{array}{l}\text { Orissa, Bihar, } \\
\text { Uttar Pradesh }\end{array}$ & $\begin{array}{l}\text { Floods caused by heavy rains; } \\
50,000 \text { houses destroyed; over } \\
200,000 \text { hectares of cropland } \\
\text { destroyed }\end{array}$ & $\begin{array}{l}51 \text { dead } \\
\$ 527 \text { mill. Damage }\end{array}$ \\
\hline May & $\begin{array}{l}\text { Uttar Pradesh, } \\
\text { Shahjahanpur, } \\
\text { Lakhimpur-Kheri, } \\
\text { Budaun, } \\
\text { Ambedka, Bareilly }\end{array}$ & $\begin{array}{l}\text { Thunderstorm with winds up to } \\
70 \mathrm{~km} / \mathrm{h} \text {; heavy rains }\end{array}$ & $\begin{array}{l}42 \text { dead } \\
50 \text { injured }\end{array}$ \\
\hline December & $\begin{array}{l}\text { Cuddalore (Tamil } \\
\text { Nadu) }\end{array}$ & $\begin{array}{l}\text { Tropical cyclone Thane with } \\
\text { winds up to } 125 \mathrm{~km} / \mathrm{h} ; 200,000 \\
\text { houses damaged }\end{array}$ & 47 dead \\
\hline September & $\begin{array}{l}\text { Sikkim (and Nepal } \\
\text { and China) }\end{array}$ & $\begin{array}{l}\text { Earthquake magnitude } 6.9 ; \\
\text { aftershocks; over } 100,000 \\
\text { houses damaged }\end{array}$ & $\begin{array}{l}\text { At least } 88 \text { dead } \\
154 \text { injured } \\
30,000 \text { homeless } \\
\$ 20 \text { mill. Damage }\end{array}$ \\
\hline January & $\begin{array}{l}\text { Many northern } \\
\text { states }\end{array}$ & $\begin{array}{l}\text { Cold wave with }-23 \mathrm{C} \\
\text { temperatures }\end{array}$ & 80 dead \\
\hline December & $\begin{array}{l}\text { Uttar Pradesh, } \\
\text { Punjab, Haryana }\end{array}$ & $\begin{array}{l}\text { Cold wave with temperatures } \\
\text { below } 0 \text { degrees } C ; \text { heavy snow; } \\
\text { damage to croplands and travel } \\
\text { disruptions }\end{array}$ & 132 dead \\
\hline
\end{tabular}




\begin{tabular}{|c|c|c|c|}
\hline \multicolumn{2}{|c|}{ 2) Man-made disasters ${ }^{136}$} & \multirow[b]{2}{*}{ Fire in hospital } & \multirow[b]{2}{*}{89 dead } \\
\hline September & Calcutta & & \\
\hline July & Uttar Pradesh & Train hits bus at railway crossing & $\begin{array}{l}35 \text { dead } \\
39 \text { injured }\end{array}$ \\
\hline July & Uttar Pradesh & $\begin{array}{l}\text { Kalka Mail passenger train } \\
\text { derails }\end{array}$ & $\begin{array}{l}68 \text { dead } \\
100 \text { injured } \\
\$ 2 \text { mill. damage } \\
\end{array}$ \\
\hline September & Chennai & Two trains collide & $\begin{array}{l}10 \text { dead } \\
52 \text { injured }\end{array}$ \\
\hline October & Darjeeling & $\begin{array}{l}\text { Overcrowded bridge collapses } \\
\text { during public gathering }\end{array}$ & $\begin{array}{l}32 \text { dead } \\
132 \text { injured }\end{array}$ \\
\hline October & $\begin{array}{l}\text { Arunachal } \\
\text { Pradesh }\end{array}$ & $\begin{array}{l}\text { Suspension footbridge collapses } \\
\text { while people are crossing it }\end{array}$ & 30 dead \\
\hline January & Kerala & Stampede at Sabarimala Temple & 100 dead \\
\hline January & Kalapet & $\begin{array}{l}\text { Poisonous chlorine leak at } \\
\text { chemical plant }\end{array}$ & 300 injured \\
\hline July & Assam & $\begin{array}{l}\text { Bomb explosion causes train to } \\
\text { derail; } 200 \text { meters of rail track } \\
\text { destroyed }\end{array}$ & 100 injured \\
\hline July & Mumbai & Triple bomb explosions & $\begin{array}{l}31 \text { dead } \\
137 \text { injured }\end{array}$ \\
\hline September & Delhi & $\begin{array}{l}\text { Bomb explosion at Delhi High } \\
\text { Court }\end{array}$ & $\begin{array}{l}13 \text { dead } \\
76 \text { injured }\end{array}$ \\
\hline November & Haridwar & Stampede at religious festival & $\begin{array}{l}20 \text { dead } \\
50 \text { injured }\end{array}$ \\
\hline December & Rajasthan & $\begin{array}{l}\text { Hospital patients die for lack of } \\
\text { care following doctors' strike }\end{array}$ & 60 dead \\
\hline
\end{tabular}

136 The man-made disasters are categorized as major fires or explosions, aviation disasters, maritime disasters, rail and cableway disasters, collapses of buildings or bridges, and miscellaneous (such as terrorist acts, riots or stampedes) 
Table 43 highlights half a dozen, highly publicized supply chain disruptions that happened in India over the past few years:

Table 44: RECENT EXAMPLES OF INDIAN SUPPLY CHAIN DISRUPTIONS

\begin{tabular}{|c|c|c|c|c|c|}
\hline When & $\begin{array}{l}\text { Company or } \\
\text { industry } \\
\text { affected }\end{array}$ & $\begin{array}{l}\text { Nature of } \\
\text { disruption }\end{array}$ & Impact & $\begin{array}{l}\text { Underlying } \\
\text { cause }\end{array}$ & Source \\
\hline $\begin{array}{l}\text { Nov. } \\
2008\end{array}$ & Entire nation & $\begin{array}{l}\text { November } \\
\text { terrorist attack } \\
\text { on several } \\
\text { high-profile } \\
\text { Mumbai } \\
\text { targets. }\end{array}$ & $\begin{array}{l}\text { Loss of life } \\
\text { (160+ fatalities), } \\
\text { property } \\
\text { damage, } \\
\text { political } \\
\text { repercussions }\end{array}$ & $\begin{array}{l}\text { Security risk: } \\
\text { Conflict with } \\
\text { Pakistan over } \\
\text { Kashmir } \\
\text { (terrorism } \\
\text { threat) }\end{array}$ & $\begin{array}{l}\text { Procurement } \\
\text { Intelligence } \\
\text { Unit blog, (S. } \\
\text { Khan, 2012) }\end{array}$ \\
\hline $\begin{array}{l}\text { August, } \\
2010\end{array}$ & $\begin{array}{l}\text { Transportation } \\
\text { \& logistics }\end{array}$ & $\begin{array}{l}\text { Two cargo } \\
\text { ships collided } \\
\text { outside } \\
\text { Mumbai }\end{array}$ & $\begin{array}{l}\text { Oil spill; one } \\
\text { ship capsized; } \\
200 \text { containers } \\
\text { lost; closure of } \\
\text { two Mumbai } \\
\text { ports for } 2 \\
\text { weeks; \$4 billion } \\
\text { in goods } \\
\text { delayed }\end{array}$ & $\begin{array}{l}\text { Illegal } \\
\text { communicatio } \\
\text { n errors (two } \\
\text { ships were } \\
\text { using different } \\
\text { radio } \\
\text { frequencies) }\end{array}$ & $\begin{array}{l}\text { www.Indiane } \\
\text { xpress.com, } \\
\text { (Webb, 2012) }\end{array}$ \\
\hline $\begin{array}{l}\text { July, } \\
2006\end{array}$ & Transportation & $\begin{array}{l}\text { Seven train } \\
\text { bombings over } \\
11 \text { minutes in } \\
\text { Mumbai }\end{array}$ & $\begin{array}{l}210 \text { killed, } 714 \\
\text { injured, } \\
\text { substantial } \\
\text { damage to } \\
\text { rolling stock, } \\
\text { tracks and } \\
\text { stations }\end{array}$ & $\begin{array}{l}\text { Attack by } \\
\text { Islamist } \\
\text { terrorists } \\
\text { (Lashkar-e- } \\
\text { Qahhar) }\end{array}$ & $\begin{array}{l}\text { BBC News } \\
\text { and } \\
\text { Wikipedia }\end{array}$ \\
\hline $\begin{array}{l}2005, \\
2006, \\
2007\end{array}$ & $\begin{array}{l}\text { Businesses and } \\
\text { residents of } \\
\text { Mumbai. }\end{array}$ & $\begin{array}{l}\text { Severe flooding } \\
\text { in Mumbai }\end{array}$ & $\begin{array}{l}\text { Loss of life, } \\
\text { property } \\
\text { damage, severe } \\
\text { delays, loss of } \\
\text { power \& phone }\end{array}$ & $\begin{array}{l}\text { Monsoon } \\
\text { season, } \\
\text { urbanization }\end{array}$ & $\begin{array}{l}\text { The Times of } \\
\text { India }\end{array}$ \\
\hline
\end{tabular}




\begin{tabular}{|c|c|c|c|c|c|}
\hline $\begin{array}{l}\text { July, } \\
2012\end{array}$ & $\begin{array}{l}\text { Businesses and } \\
\text { transportation } \\
\text { shut down for } \\
\text { hours or days. }\end{array}$ & $\begin{array}{l}\text { The world's } \\
\text { biggest power } \\
\text { outage }\end{array}$ & $\begin{array}{l}620 \text { million } \\
\text { people w/o } \\
\text { electricity in } 20 \\
\text { of India's } 28 \\
\text { states. }\end{array}$ & $\begin{array}{l}\text { Growing } \\
\text { demand for } \\
\text { power; theft } \\
\text { of power, } \\
\text { insufficient } \\
\text { infrastructure }\end{array}$ & $\begin{array}{l}\text { www.Huffing } \\
\text { tonpost.com }\end{array}$ \\
\hline $\begin{array}{l}\text { Dec. } \\
1984\end{array}$ & $\begin{array}{l}\text { Union Carbide } \\
\text { lost unknown } \\
\text { amounts, incl. } \\
\text { \$470 million } \\
\text { settlement } \\
\text { with Indian } \\
\text { govt. }\end{array}$ & $\begin{array}{l}\text { History's worst } \\
\text { industrial } \\
\text { accident: } 40 \\
\text { tons of methyl } \\
\text { isocyanate gas } \\
\text { leaked from a } \\
\text { pesticide plant } \\
\text { in Bhopal }\end{array}$ & $\begin{array}{l}\text { 3,800 people } \\
\text { killed, } \\
\text { thousands } \\
\text { injured, lasting } \\
\text { impact on } \\
\text { Bhopal }\end{array}$ & $\begin{array}{l}\text { Poor } \\
\text { maintenance, } \\
\text { faulty } \\
\text { equipment } \\
\text { and } \\
\text { procedures. }\end{array}$ & $\begin{array}{l}\text { www.ncbi.nl } \\
\text { m.nih.gov }\end{array}$ \\
\hline $\begin{array}{l}2010- \\
2012\end{array}$ & $\begin{array}{l}\text { Logistics \& } \\
\text { transportation. } \\
\text { Severe threat } \\
\text { in Uttar } \\
\text { Pradesh, } \\
\text { Madhya } \\
\text { Pradesh }{ }^{137} \text {, and } \\
\text { around Delhi }\end{array}$ & $\begin{array}{l}\text { "India is } \\
\text { becoming } \\
\text { increasingly } \\
\text { noted for large- } \\
\text { scale theft } \\
\text { incidents, } \\
\text { including truck } \\
\text { hijackings and } \\
\text { warehouse } \\
\text { robberies" }\end{array}$ & $\begin{array}{l}\$ 13 \text { million } \\
\text { reported thefts } \\
\text { of iron last } 6 \\
\text { months of } 2010 \text {. } \\
\text { Some violence. }\end{array}$ & $\begin{array}{l}\text { Opportunistic } \\
\text { criminals, } \\
\text { more high } \\
\text { value freight } \\
\text { and high } \\
\text { commodities } \\
\text { prices }\end{array}$ & $\begin{array}{l}\text { (Burges, } \\
2011,2012 \text { ) }\end{array}$ \\
\hline
\end{tabular}

137 Uttar Pradesh and Madhya Pradesh are two of the poorest states in India, with annual GDP per person of $\$ 666$ and $\$ 849$ respectively, compared to the national average of $\$ 1,329$ (Economist, 2012a). 


\section{APPENDIX D: SUMMARY OF RESPONSES TO THE PROFILE QUESTIONS}

Distribution of respondents, by organizational membership:

- Indo-American Chamber of Commerce (IACC) 13

$13 \quad 30.2 \%$

- Bombay Chamber of Industry (BCl)

$12 \quad 27.9 \%$

- Council of Supply Chain Management Professionals (CSCMP) $920.9 \%$

- Indian Merchant Chamber (IMC)

$9 \quad 20.9 \%$

Distribution of respondents, by organizational level:

- Managing Director, VP, General Manager, C-Level Executive $18 \quad 41.9 \%$

- Chair, owner, CEO, President $920.9 \%$

- Manager $614.0 \%$

- Director, Senior Manager $\quad 5 \quad 11.6 \%$

- Analyst, Specialist, Coordinator, Consultant $4 \quad 4.3 \%$

- Other $12.3 \%$

Distribution of respondents, by functional area (multiple responses allowed):

- Supply chain management 25

$58.1 \%$

- General management $24 \quad 55.8 \%$

- Sales and marketing management $\quad 11 \quad 25.6 \%$

- Human resources $\quad 6 \quad 14.0 \%$

- Other $6 \quad 14.0 \%$

- Production and manufacturing management $\quad 5 \quad 11.6 \%$

- Engineering and product development $\quad 5 \quad 11.6 \%$

- Financial management, accounting, IT $3 \quad 3.0 \%$

Distribution of respondents, by general sector:

- Services, incl. education and government $\quad 16 \quad 37.2 \%$

- Durable goods $10 \quad 23.3 \%$

- Non-durable goods or consumables $818.6 \%$

- Capital goods (buildings, machines, heavy equipment, etc.) $7 \quad 16.3 \%$

- Natural resources $\quad 6 \quad 14.0 \%$

Distribution of respondents, by location of global headquarters:

$\begin{array}{lll}\text { - India } & 33 & 76.7 \%\end{array}$

- Abroad (USA, Australia, Germany and Qatar) $10 \quad 23.3 \%$

Distribution of respondents, by ownership:

- Fully Indian

- Mixed, with majority foreign owned

$28 \quad 65.1 \%$

- Fully foreign

$6 \quad 14.0 \%$

- Mixed, with majority Indian owned

$5 \quad 11.6 \%$

$4 \quad 9.3 \%$ 
Distribution of respondents, by company activity (multiple responses allowed):

- Owns \& operates own production and development facilities in India $\quad 27 \quad 62.8 \%$

- Sources from Indian companies $23 \quad 53.5 \%$

$\begin{array}{lll}\text { - Other or none of the above } & 6 & 14.0 \%\end{array}$

Distribution of respondents, by business type (Indian National Industrial Classification 2008; multiple responses allowed):

- Manufacturing

$27 \quad 62.8 \%$

- Transportation and storage

$9 \quad 20.9 \%$

- Agriculture, forestry or fishing

$5 \quad 11.6 \%$

- Construction

$5 \quad 11.6 \%$

- Information or communication, incl. software or IT services

$49.3 \%$

- Electricity, gas, steam or air conditioning supply

$3 \quad 7.0 \%$

- Wholesale or retail trade, repair of motor vehicles or motorcycles $3 \quad 7.0 \%$

- Professional, scientific or technical activities

$3 \quad 7.0 \%$

- Education

$3 \quad 7.0 \%$

- Mining or quarrying

$2 \quad 4.7 \%$

- Human, health or social work activities

$2 \quad 4.7 \%$

- Other service activities, incl. trade associations

$2 \quad 4.7 \%$

- Water supply, sewerage, waste management or remediation activities $1 \quad 2.3 \%$

- Accommodation or food service activities

- Real estate activities

$1 \quad 2.3 \%$

Distribution of respondents, by annual global sales, in US dollars:

- Less than $\$ 1,000,000$

$9 \quad 20.9 \%$

- $\$ 1,000,000-\$ 10,000,000$

$14 \quad 32.6 \%$

- $\$ 10,000,000-\$ 100,000,000$

$7 \quad 16.3 \%$

- $\$ 100,000,000-\$ 1,000,000,000$

$3 \quad 7.0 \%$

- $\$ 1,000,000,000-\$ 10,000,000,000$

$1 \quad 2.3 \%$

- More than $\$ 10,000,000,000$

$6 \quad 14.0 \%$

Distribution of respondents, by functional activity done in India (multiple responses allowed):

- Production or development, incl. goods or all kinds of services $31 \quad 32.1 \%$

- Marketing and Sales $\quad 22 \quad 51.2 \%$

- Sourcing $20 \quad 46.5 \%$

- Other $\quad 8 \quad 18.6 \%$ 
Distribution of respondents, by category of goods or services sourced or produced in India (Reserve Bank of India and International Monetary Fund classification; multiple responses allowed):

- Other manufactured goods $12 \quad 27.9 \%$

- Engineered goods, incl. transportation equipment, machinery $1125.6 \%$

- Chemicals and related products, incl. pharmaceuticals, cosmetics $920.9 \%$

- Agricultural and allied products $6 \quad 14.0 \%$

- Transportation services (goods or passengers)

$6 \quad 14.0 \%$

- Other business services, incl. accounting, law, consulting, R\&D, storage

5

- Maintenance, repairs or manufacturing services

$11.6 \%$

- Other products

$49.3 \%$

- Petroleum products

- Electricity, gas or water supply

- Ores and minerals

$3 \quad 7.0 \%$

- Telecommunications, computer or information services, incl. software

- Construction services, incl. architecture

- Personal, cultural or recreational services, incl. A/V, educational

- Government goods or services

- Textiles and textile products

- Handicrafts

Distribution of respondents, by the annual value of what is sourced, produced or developed in India:

- Less than INR 10,00,000 (10 lakhs)

$\begin{array}{rr}0 & 0.0 \% \\ 6 & 14.0 \% \\ 11 & 25.6 \% \\ 10 & 23.3 \% \\ 6 & 14.0 \% \\ 7 & 16.3 \%\end{array}$

Distribution of respondents, by number of persons directly employed in India:

- None

- $1-10$

- $11-100$

- $101-1,000$

$14 \quad 32.6 \%$

- $1,001-10,000$

$11 \quad 25.6 \%$

- $10,001-100,000$

$8 \quad 18.6 \%$

- More than 100,000

$2 \quad 4.7 \%$

$2 \quad 4.7 \%$ 
Distribution of respondents, by which percentage of products or services sourced or produced in India is exported out of India:

- $100 \%$

$7 \quad 16.3 \%$

- $75-99 \%$

$2 \quad 4.7 \%$

- $50-74 \%$

$8 \quad 18.6 \%$

- $25-49 \%$

$7 \quad 16.3 \%$

- $1-24 \%$

$12 \quad 27.9 \%$

- $0 \%$

$7 \quad 16.3 \%$

Distribution if respondents, by location of their major Indian suppliers and/or major Indian production facilities (multiple answers possible):

- Central India

$8 \quad 18.6 \%$

- East India

$8 \quad 18.6 \%$

- North India

$20 \quad 46.5 \%$

- North-East India

$2 \quad 4.7 \%$

- South India

$22 \quad 51.2 \%$

- West India

$35 \quad 81.4 \%$

Distribution of respondents, by how many years they have sourced or operated in India:

- Less than 3 years

- 3-10 years

- $10-20$ years

- More than 20 years

- Don't know
$6 \quad 14.0 \%$

$6 \quad 14.0 \%$

$8 \quad 18.6 \%$

$22 \quad 51.2 \%$

$1 \quad 2.3 \%$ 